\title{
Changing transitions to adulthood in Vietnam's remote northern uplands: A focus on ethnic minority youth and their families [Vietnamese]
}

Bussarawan Teerawichitchainan

Hac Van Vinh

Nguyen Thi Phuong Lan

Follow this and additional works at: https://knowledgecommons.popcouncil.org/departments_sbsr-pgy

Part of the Demography, Population, and Ecology Commons, Family, Life Course, and Society Commons, Gender and Sexuality Commons, International Public Health Commons, Maternal and Child Health Commons, and the Medicine and Health Commons How does access to this work benefit you? Let us know!

\section{Recommended Citation}

Teerawichitchainan, Bussarawan, Hac Van Vinh, and Nguyen Thi Phuong Lan. 2007. "Changing transitions to adulthood in Vietnam's remote northern uplands: A focus on ethnic minority youth and their families [Vietnamese]." Hanoi: Population Council. 
(2) Population Council

BUSSARAWAN TEERAWICHITCHAINAN - HAC VĂN VINH NGUYỄN TH! PHUƠNG LAN - NGUYỄN THÀNH TRUNG

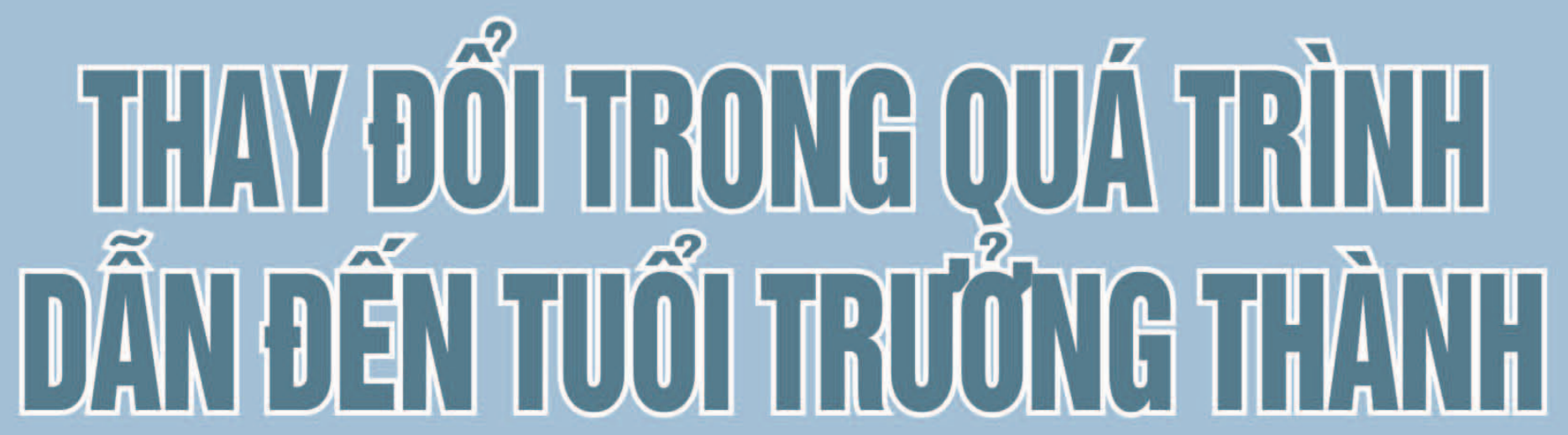

CHỦ ĐỀ Ở NHÓM THANH NIÊN DÂN TỘC THIỂU SỐ VÀ GIA ĐİNH MIỀN NÚI PHÍA BẮC VIỆT NAM
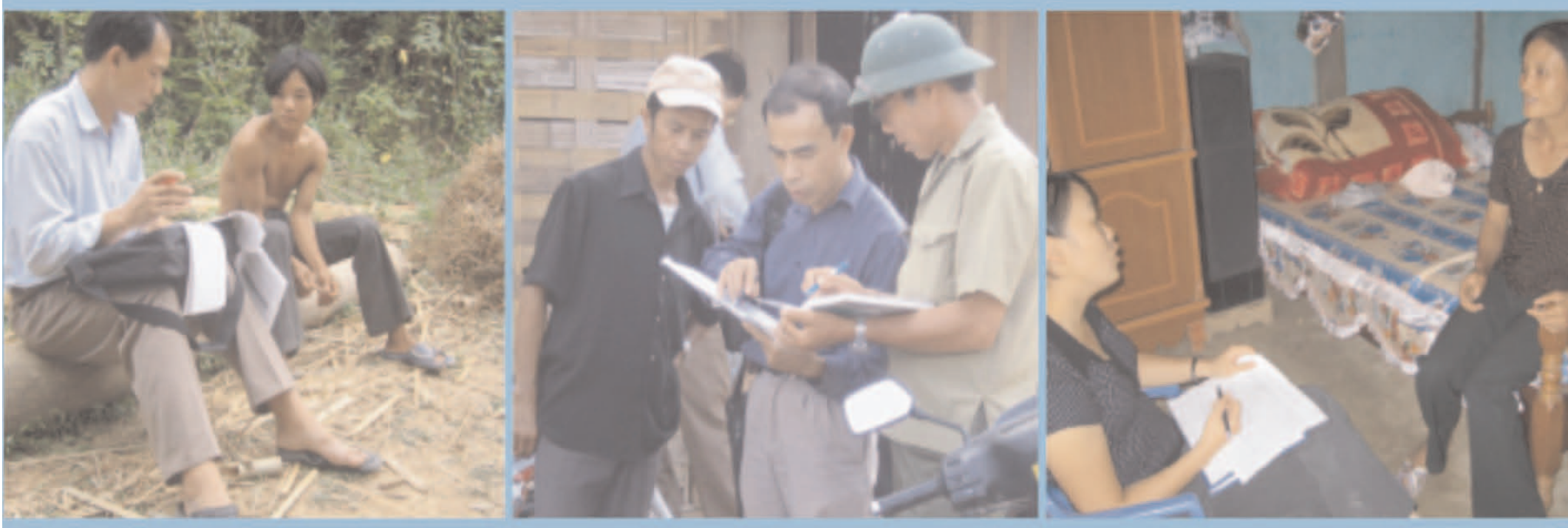
Hộl ĐỒNG DÂN SỐ VÀ TRƯờNG ĐẠl HỌC Y THÁl NGUYÊN

\section{THAY ĐỔ TRONG QUÁ TRINNH DÂN ĐẾN TUỔI TRỬ̛NG THÀNH \\ CHỦ ĐỀ: Ở NHÓM THANH NIÊN DÂN TộC THIỂU SỐ VÀ GIA ĐİNH, MIỀN NÚI PHÍA BẤC VIẸTT NAM}

Tác giả: Bussarawan Teerawichitchainan

Hạc Văn Vinh

Nguyễn Thị Phương Lan

Nguyễn Thành Trung

NHÀ XUẤT BẢN ĐẠI HỌC QUỐC GIA HÀ NộI 


\section{Tác giả viết báo cáo:}

Bussarawan Teerawichitchainan- Hội đồng Dân số

Hạc Văn Vinh-

Trường Đại học $Y$ khoa Thái Nguyên

Nguyễn Thị Phương Lan-

Trường Đại học $Y$ khoa Thái Nguyên

Nguyễn Thành Trung

Trường Đại học $Y$ khoa Thái Nguyên

\section{Cố vấn:}

Sajeda Amin-

Hội đồng Dân số

Jane Hughes-

Hội đồng Dân số

Báo cáo có sự hỗ trợ của nhà tài trợ 


\section{MỤC LỤC}

Trang

Tóm tắt

Chương 1: Giới thiệu và tổng quan tài liệu 12

1. Giới thiệu 12

2. Chương trình xoá đói giảm nghèo và sự kém phát triển của người dân tộc thiểu số 14

3. Phúc lợi xã hội của thanh niên dân tộc thiểu số ở Việt Nam 17

4. Mục tiêu nghiên cứu cụ thể 22

Chương 2: Phương pháp nghiên cứu $\quad 24$

1. Lựa chọn địa điểm 24

2. Thu thập số liệu $\quad 25$

3. Mô tả số liệu 26

Chương 3: Tình hình kinh tế - xã hội ở vùng nghiên cứu 32

1. Đặc điểm tự nhiên và tiếp cận 33

2. Đặc điểm nhân khẩu học 36

3. Cơ sở hạ tầng 38

4. Kinh tế và thu nhập - Các hoạt động thông thường 42

5. Việc tham gia vào chương trình xoá đói giảm nghèo 46

Chương 4: Học tập và quá trình chuyển dịch đến việc làm 53

1. Giới thiệu

2. Tổng quan về cung cấp giáo dục trong vùng nghiên cứu 54

3. Sự khác nhau về việc học tập ở vùng nghiên cứu 61

4. Giải thích nguyên nhân sự khác nhau trong việc học tập 67

5. Sự chuyển tiếp từ học tập đến lao động kiếm sống 78 
Chương 5: Quá trình đi đến hôn nhân và trở thành cha mẹ, những liên quan đến tình dục và sức khoẻ sinh sản

1. Giới thiệu

2. Khoảng thời gian kết hôn

92

3. Kết hôn

99

4. Sau kết hôn

114

Chương 6: Kết luận và khuyến nghị

125

Tài liệu tham khảo

131 


\section{TÓM TẮT}

Kinh tế của Việt Nam phát triển nhanh chóng đã mang lại cho thanh niên ngày nay những cơ hội mới cũng như những nguy cơ mới chưa từng xuất hiện ở thế hệ trước. Điều này đúng với cả dân tộc Kinh và các dân tộc thiểu số. Nhiều người dân tộc thiểu số có sức khoẻ kém, nghèo và ít được đến trường. Người dân tộc thiểu số sống ở vùng sâu, vùng xa chiếm 15\% trong số 84 triệu người dân Việt Nam, theo ước tính gần đây số hộ nghèo chiếm tới $61 \%$. Mặc dù gần đây Chính phủ Việt Nam đã nỗ lực để tăng cường xoá đói giảm nghèo ở vùng sâu vùng xa nhưng đời sống của phần lớn dân tộc thiểu số chưa có những thay đổi đáng kể, điều này trái ngược với nhóm người Kinh đã báo cáo là đời sống của họ đã được cải thiện một cách vững chắc. Trong năm 2007, trên một nửa số thanh niên dân tộc thiểu số ở độ tuổi từ 15 đến 29 đã lớn lên trong những hộ thực sự nghèo đói. Nhiều thanh niên đã phải sớm làm chủ gia đình, một số đã phải thoát ly khỏi quê hương để tìm những công việc, những cơ hội thoát khỏi đói nghèo để lại toàn bộ trách nhiệm với gia đình cho những người ở nhà.

Để lập chương trình can thiệp nhằm tăng cường sự phát triển cho con người và thúc đẩy sự phát triển kinh tế của Việt Nam, cần có những hiểu biết đầy đủ về quá trình trưởng thành trong nhóm thanh niên này. Với những dẫn chứng giàu sức thuyết phục, nghiên cứu này chỉ ra nguyên nhân và kết quả trong quá trình trưởng thành của thanh niên dân tộc ít người từ 15 đến 29 tuổi ở miền núi phía Bắc Việt Nam và đề xuất những chính sách phù hợp. Đầu tiên, nghiên cứu tìm hiểu mức độ thay đổi và các yếu tố ảnh hưởng đến sự thay đổi của thanh niên về quá trình học tập, tìm kiếm việc làm và việc kết hôn lập gia đình thực hiện nghĩa vụ làm cha mẹ. Hơn nữa, nghiên cứu này cũng tìm hiểu những kết quả của phúc lợi xã hội với đời sống của thanh niên, đặc biệt là những vấn đề liên quan đến tình dục và sức khoẻ sinh sản. Mục đích của nghiên cứu là so sánh trực tiếp giữa người dân tộc thiểu số và người Kinh sống gần nhau ở những xã vùng sâu có thực hiện chương trình xoá đói giảm nghèo; tìm hiểu sự khác nhau trong cuộc sống của thanh niên dân tộc thiểu số và gia đình họ trong việc tiếp cận với chương trình giảm nghèo cũng như những nỗ lực phát triển khác gần đây của Nhà nước.

\section{Phương pháp nghiên cứu}

Chúng tôi nghiên cứu quá trình trưởng thành của thanh niên dân tộc thiểu số qua tìm hiểu thực địa ở huyện Võ Nhai - huyện kém phát triển nhất và là vùng xa nhất của 
tỉnh Thái Nguyên. Những nghiên cứu này thực hiện ở 2 xã Phương Giao và Tràng Xá. Người Kinh, Dao và H'mong là các dân tộc chính sinh sống ở đây. Những xã này được lựa chọn nghiên cứu vì họ tiêu biểu cho vùng nghèo, vùng sâu, kinh tế nông nghiệp của miền núi phía Bắc Việt Nam. Từ sau những năm 1990, họ đã được hưởng những phúc lợi do các chương trình xoá đói giảm nghèo mang lại.

Nghiên cứu phối hợp các cách tiếp cận, kết hợp phân tích nghiên cứu định tính và định lượng từ nguồn số liệu phong phú như đánh giá nhanh, điều tra dân số, điều tra hộ gia đình, phỏng vấn sâu. 60 thanh niên từ 15 đến 49 tuổi được lựa chọn ngẫu nhiên trong nhóm dân tộc Kinh, Dao, H'mong để phỏng vấn. Mỗi thanh niên trả lời phỏng vấn hai lần cách nhau từ 4 đến 6 tuần. Trong 4 tháng thu thập số liệu, các điều tra viên đã tiến hành gần 190 cuộc phỏng vấn sâu những thanh niên thuộc đối tượng nghiên cứu và cha mẹ họ. Dựa trên điều tra dân số của 9 làng nghiên cứu, chúng tôi lựa chọn điều tra 150 hộ gia đình. Phương pháp nghiên cứu chuyên sâu cho phép chúng tôi điều tra bối cảnh theo cả chiều rộng và chiều sâu về những hành vi của gia đình và với phương pháp này, chúng tôi đã có nhiều thuận lợi để tìm được những câu trả lời cho những câu hỏi đã đặt ra.

\section{Đặc điểm kinh tế xã hội của vùng nghiên cứu}

Trong những thập kỷ qua, những làng nghiên cứu đã có những thay đổi đáng kể về địa lý và kinh tế - xã hội. Đặc biệt những chương trình xoá đói giảm nghèo được tiến hành sau những năm 1990 khiến cho những thay đổi này nhiều hơn. Hoạt động chủ yếu của chương trình xoá đói giảm nghèo là phát triển cơ sở hạ tầng, hỗ trợ cho giáo dục và $\mathrm{y}$ tế, chương trình thẻ tín dụng và phát triển nông nghiệp. Những người Kinh mặc dù là láng giềng của người dân tộc thiểu số nhưng dường như họ đã tiếp thu nhanh chóng và trở thành người nhận được nhiều lợi ích hơn từ những hỗ trợ này của Nhà nước.

Kinh tế chính của vùng nghiên cứu là nông nghiệp. Những người nông dân trồng lúa chủ yếu để tiêu thụ trong gia đình, ngô và mía chiếm phần lớn thu hoạch của họ. Nhiều gia đình, đặc biệt là người Kinh thu nhập chủ yếu từ các mùa vụ nhưng họ bị thiếu thông tin về giá cả thị trường cũng như bị phụ thuộc rất nhiều vào phân bón và giống cho sản xuất. Thiếu nước, thiếu thông tin về cung cầu của thị trường, thiếu vốn là những cản trở chủ yếu trong sản xuất nông nghiệp ở đây. Hầu hết đời sống của người dân trong làng phụ thuộc vào nông nghiệp dù họ là nông dân, lao động làm thuê hay

buôn bán nhỏ. Những người làm các nghề phi nông nghiệp rất ít. Không có khu công nghiệp nào gần địa điểm nghiên cứu trong vòng bán kính $20 \mathrm{~km}$. Chỉ có tham gia làm việc trong chính quyền địa phương và kinh doanh nhỏ là hai nghề phi nông nghiệp. Nguồn thu nhập của người Kinh phong phú hơn của những người dân tộc thiểu số. 
Từ năm 2000, ở những làng này đã có nhiều dự án phát triển cơ sở hạ tầng, bao gồm làm đường, mắc điện lưới. Hầu hết các hộ gia đình đã có điện. Các đường liên thôn cũng đã được xây dựng. Tỷ lệ hộ gia đình có xe máy đã tăng lên trong những năm qua. Sự kết hợp giữa việc cải tạo đường xá và sự phổ biến của xe máy cũng là điều kiện thuận lợi để người dân được hưởng các dịch vụ y tế công cộng, điện thoại cũng không còn là hiếm có. Nước sạch và vệ sinh môi trường cũng đã được chú ý cải tạo mặc dù kết quả còn hạn chế. Nhìn tổng thể cơ sở hạ tầng đặc biệt là đường xá ở những làng người Kinh tốt hơn những làng người Dao và H'mong.

Mặc dù lãnh đạo địa phương và người dân có cái nhìn lạc quan với sự cải thiện điều kiện sống trong những năm gần đây nhưng nghèo đói vẫn còn tồn tại . Cái nghèo biểu hiện ở nhiều khía cạnh khác nhau. Mất an ninh thực phẩm và nghèo đói nhìn chung đã giảm nhưng vẫn còn tồn tại ở một số làng. Dù nghèo hiện không phải là quá phổ biến nhưng đời sống của nhiều người trong số họ đói nghèo vẫn đe doạ. Không có hoặc rất ít sự trợ giúp khi người dân trong làng phải đối mặt với những khó khăn đột xuất như khi trong gia đình có người ốm đau... người Kinh và H'mong ở Tràng Xá có điều kiện thuận lợi hơn khi họ sống gần thị trấn, gần chợ, nơi có thể dễ dàng hơn trong việc tiêu thụ các sản phẩm do họ làm ra.

\section{Chuẩn bị học hành và quá trình bước sang tuổi lao động}

Phần lớn những thanh niên từ 15 đến 29 tuổi ở đây đã bước sang giai đoạn chuẩn bị tìm việc làm và bước vào cuộc sống trong bối cảnh hội nhập, tuy nhiên sự chuẩn bị này rất hạn chế. So với thanh niên ở những nơi khác, trình độ văn hoá của của thanh niên ở đây rất thấp, đặc biệt là những người dân tộc thiểu số. Trong các dân tộc tại địa điểm nghiên cứu, người H'mong có trình độ thấp nhất. Một số chưa bao giờ đến trường, chỉ có một số ít phụ nữ dân tộc thiểu số đã đến trường học vài năm để xoá mù chữ.

Chương trình xoá đói giảm nghèo triển khai từ những năm cuối của thập kỷ 90 ở đây khiến cho việc thanh niên đến trường học nhiều hơn và cơ sở hạ tầng đã được cải thiện vững chắc. Chính phủ cũng hỗ trợ trả một phần chi phí về giáo dục cho các hộ gia đình. Nhưng chúng tôi nhận thấy chỉ có rất ít thanh niên trong độ tuổi 15 đến 29 nhận được những lợi ích từ việc hỗ trợ giáo dục và cải thiện cơ sở hạ tầng trong khi nhóm thanh niên sinh sau những năm 1990 đã nhận được lợi ích trực tiếp từ những sự hỗ trợ này. Tuy vậy, những lợi ích này có xu hướng bị giới hạn theo cấp học và không đồng đều giữa các nhóm dân tộc có thu nhập khác nhau. Hơn nữa, các chương trình hỗ trợ chú ý đến việc tăng tỷ lệ trẻ đến trường hơn là tăng cường chất lượng dạy và học, theo phân tích của chúng tôi đây chính là nguyên nhân gốc rễ của việc học sinh bỏ học sớm. 
Hiện tại giáo dục tiểu học là cấp học dễ phổ cập nhất cho hầu hết học sinh, trừ số học sinh ở bản vùng sâu, vùng xa do nhà ở xa trường học nên khả năng đi học còn hạn chế. Điều kiện tự nhiên vẫn còn là trở ngại khi học trung học cơ sở - điều này tạo nên sự khác nhau giữa các dân tộc trong việc học trung học cơ sở, trung học phổ thông hoặc chuyên nghiệp. Càng lên cao, số thanh niên các dân tộc ít người đi học càng ít đi. Hơn nữa, những hỗ trợ cho giáo dục hiện nay chưa giúp cho những gia đình nghèo có đủ tiền đóng học phí cho con ở trường tiểu học và trung học cơ sở. Trình độ học vấn thấp đã ảnh hưởng xấu đến quá trình tìm việc làm của nhiều thanh niên trong vùng. Điều này đặc biệt đúng với những người muốn tìm kiếm cơ hội làm các nghề phi nông nghiệp ở các thị xã hay thành phố, học vấn thấp cũng có những tác động tiêu cực với những người làm nghề nông nghiệp.

\section{Nhũ̃ng đề xuất chính sách của chúng tôi như sau:}

Cần tiếp tục ưu tiên đầu tư cho học sinh học tập ngay từ khi còn trẻ. Ngoài ra còn phải chú ý đưa ra chương trình đào tạo bổ sung cho thanh niên và người trưởng thành đã bỏ học. Chương trình đào tạo bổ sung nên dành cho những người không còn tuổi đến trường và nội dung của chương trình này giúp giải quyết những nhu cầu cụ thể của thanh niên. Những hoạt động về giáo dục cần gắn liền với nhu cầu thực tế cuộc sống.

Chương trình cho những người lớn tuổi, học vấn thấp, đã có gia đình và vẫn làm nông nghiệp nên nhấn mạnh đến nội dung liên quan đến nông nghiệp và cuộc sống thông qua hệ thống linh hoạt, có các modul bao gồm cả về: y tế, giáo dục công dân, kỹ năng hướng nghiệp. Kiến thức về phát triển nông nghiệp và thị trường có tầm quan trọng đối với họ như là khả năng đọc và viết với mỗi con người. Những kiến thức về kinh doanh cần được giới thiệu khi người dân có những quan tâm đến việc buôn bán nhỏ.

Chương trình cho những thanh niên đã bỏ học muốn tìm kiếm công việc ngoài nghề nông nghiệp nên chú ý đến những kỹ năng hướng nghiệp. Nếu quá trình đào tạo bao gồm cả dịch vụ lao động và tư vấn thì việc thực hành nghề nghiệp là rất quan trọng.

Những chương trình đào tạo nên tăng cường những hiểu biết về kỹ năng sống để giúp thanh niên thích ứng với những thay đổi nhanh chóng của điều kiện kinh tế - xã hội. Kỹ năng sống thiết yếu như cạnh tranh nghề nghiệp sẽ giúp họ thành công dễ dàng hơn. Hơn nữa, việc đào tạo những kỹ năng sống này còn giúp họ từ bỏ những thói quen xấu như: uống rượu, hút thuốc lá, nghiện ma tuý và lối sống thiên về bạo lực.

Phương pháp và chương trình đào tạo bổ sung phải giải quyết được những nguyên nhân khiến thanh niên bỏ học. Để điều chỉnh những áp lực nghề nghiệp của tuổi thanh thiếu niên nên cho phép học sinh và giáo viên lựa chọn chương trình và thời gian học tập để có thể phù hợp với khả năng sự thích ứng của họ. Chương trình 
và phương pháp tiếp cận giáo dục cần phải chú ý đến năng lực về ngôn ngữ của học sinh dân tộc thiểu số.

Những chương trình này nên huy động sự tham gia của nhiều bên liên quan, bao gồm nhà nước, tư nhân, các tổ chức phi chính phủ và các nhà tài trợ. Hơn nữa, những người lãnh đạo ở địa phương, cha mẹ của họ cũng phải có trách nhiệm vì họ là những người có ảnh hưởng rất lớn đến sự học tập và quá trình tìm việc làm của thanh niên.

\section{Sức khoẻ tình dục và sức khoẻ sinh sản}

Sức khoẻ tình dục và sinh sản của thanh niên xuất hiện nhiều nguy cơ vì kiến thức của họ về lĩnh vực này rất hạn chế trong hoàn cảnh có nhiều thách thức về quan hệ tình dục trước hôn nhân, sau kết hôn cũng như những thay đổi nhanh chóng về kinh tế - xã hội. Nghiện ma tuý và mại dâm vẫn tồn tại trong khu vực nghiên cứu nhưng chưa được sự quan tâm chú ý cần thiết. Những phân tích của chúng tôi cho thấy nam và nữ thanh niên trẻ có học vấn thấp hoặc không biết chữ - phần lớn là người thuộc dân tộc thiểu số - có nguy cơ cao hơn những người bạn của họ có học vấn cao hơn.

Quan hệ xã hội được mở rộng và sự thay đổi nhanh chóng của cuộc sống đã tác động đến hành vi quan hệ trước hôn nhân ở cả người dân tộc Kinh và dân tộc thiểu số. Thế hệ thanh niên ngày nay tự quyết định nhiều hơn thế hệ cha mẹ trong quan hệ nam nữ. Mặc dù quan hệ tình dục trước hôn nhân không được xã hội chấp nhận nhưng điều này không những phổ biến mà còn tăng lên trong thời gian gần đây ở các nhóm dân tộc. Trái ngược với giả thuyết, chúng tôi thấy thanh niên người H'mong có quan hệ tình dục trước hôn nhân không nhiều hơn những nhóm thanh niên thuộc các dân tộc khác. Dù hành vi quan hệ tình dục trước hôn nhân đã không còn là việc ít thấy nhưng những thanh niên chưa kết hôn rất ít được tiếp cận với kiến thức và dịch vụ chăm sóc sức khoẻ sinh sản. Hầu hết trong số họ thiếu kiến thức về dậy thì, quan hệ tình dục an toàn, kế hoạch hoá gia đình, HIV/AIDS và những bệnh lây truyền qua đường tình dục. Tỷ lệ phụ nữ có thai trước hôn nhân cho thấy thanh niên không có đủ thông tin để tiếp cận với các phương pháp tránh thai.

Thanh niên đã kết hôn phải đối mặt với thách thức liên quan đến sức khoẻ và quyền về tình dục, sức khoẻ sinh sản. Mặc dù thanh niên ngày nay kết hôn muộn hơn lứa tuổi cha mẹ của họ nhưng kết hôn ở tuổi vị thành niên vẫn phổ biến ở phụ nữ người Dao và H'mong có trình độ học vấn thấp. Những đám cưới giữa người Kinh và người các dân tộc như H'mong, Dao vẫn xuất hiện nhưng không phổ biến. Hơn nữa, thách cưới cao, trang phục ngày cưới phức tạp, những bữa cỗ đông người trở thành không thể thiếu của lễ cưới ngày nay. Nhiều gia đình, đặc biệt là người dân tộc thiểu số sau khi tổ chức đám cưới đều mang công mắc nợ. Do nhu cầu của đời 
sống, nhiều bà mẹ đã phải đi làm sớm sau khi sinh, điều này có ảnh hưởng rất xấu đến sức khoẻ của bà mẹ và trẻ em.

Một số các cặp vợ chồng trong vùng nghiên cứu không thực hiện quy mô gia đình theo yêu cầu mặc dù việc kế hoạch hóa gia đình được cộng đồng chấp nhận một cách rộng rãi và các phương pháp tránh thai đã được miễn phí để dễ phổ cập. Mong muốn có con trai là lý do chính giải thích tại sao phụ nữ không thực hiện sinh đẻ có kế hoạch. Hơn nữa, người phụ nữ chủ yếu lựa chọn phương pháp đặt dụng cụ tử cung và thuốc tránh thai, thiếu sự tham gia của người chồng nên việc kiểm soát sinh đẻ trở thành gánh nặng của người phụ nữ. Nhiều phụ nữ đã nói họ không thoải mái với các biện pháp tránh thai đang sử dụng nhưng một số người cam chịu dù nhiều người đã ngừng sử dụng các biện pháp tránh thai trong thời gian dài. Để tránh thai ngoài ý muốn, nhiều phụ nữ có gia đình đặc biệt là người Kinh và một số người Dao dùng cách tránh thai bằng tính vòng kinh hoặc nạo phá thai. Các phương tiện kế hoạch hoá gia đình mặc dù đã được phân phát rộng rãi nhưng nhiều cặp thanh niên đặc biệt là thanh niên người dân tộc sống ở vùng sâu không được hướng dẫn cần làm thế nào để sử dụng các phương pháp kế hoạch hoá gia đình mà họ nhận được.

Sau đây là nhũ̃ng đề xuất về chính sách:

Chương trình nên giải quyết những nhu cầu khác nhau của đối tượng đã kết hôn và chưa kết hôn. Chú ý đến những thanh niên nam và nữ có học vấn thấp.

Đối với những thanh niên chưa kết hôn, họ cần những chương trình trong đó có sự kết hợp những kỹ năng sống để tăng cường hiểu biết về sức khoẻ sinh sản và tình dục. Những chủ đề nên bao gồm về sinh lý sức khoẻ sinh sản, dậy thì, tình dục an toàn, HIV/AIDS, các bệnh lây truyền qua đường tình dục và các phương pháp kế hoạch hoá gia đình.

Chương trình cho những thanh niên chưa kết hôn nên được tiến hành trước tuổi dậy thì và sử dụng cách tiếp cận dựa vào cộng đồng và trường học. Chương trình nên chú ý đến vấn đề ngôn ngữ và tập quán khác nhau của mỗi dân tộc. Việc tiếp cận dễ dàng hơn với dịch vụ sức khoẻ sinh sản và tình dục, tư vấn là thực sự cần thiết. Cần làm sao để những dịch vụ này được phổ biến hơn, dụng cụ tránh thai được phân phát tốt hơn. Muốn thế, những việc này cần được thảo luận thấu đáo với các bên liên quan ở địa phương, bao gồm cả những thanh niên, cha mẹ họ và những người lãnh đạo địa phương.

Với thanh niên đã kết hôn, những chương trình này nên hướng vào giải quyết nhu cầu của họ về mục đích sinh sản, giúp họ nhận được dịch vụ sức khoẻ sinh sản có chất lượng và có điều kiện để bước vào giai đoạn làm mẹ an toàn. Cách tốt nhất để thực hiện những chương trình này là tìm mọi cách thúc đẩy phát triển kinh tế gia đình ở nông thôn. 
Chương trình kế hoạch hoá gia đình nên tập trung vào việc phổ biến những thông tin chính xác và cung cấp các biện pháp kế hoạch hoá gia đình như dụng cụ tử cung, uống thuốc tránh thai và sử dụng bao cao su với chi phí thấp nhất hoặc miễn phí. Chương trình nên khuyến khích nam giới tham gia thực hiện kế hoạch hóa gia đình. Điều này có thể tiến hành theo hệ thống hiện có chẳng hạn như thông qua mạng lưới cộng tác viên dân số. Nên theo dõi để giám sát chất lượng kế hoạch hoá gia đình đang tiến hành tại các làng cũng như đảm bảo để việc nạo phá thai và hút điều hoà kinh nguyệt được tiến hành với tiêu chuẩn chất lượng cao.

Để tăng cường chương trình làm mẹ an toàn cần tiến hành đỡ đẻ an toàn do nhân viên y tế tiến hành bao gồm việc chăm sóc toàn diện trước và sau sinh cho bà mẹ và trẻ em. 


\section{Chương I \\ GIỚI THIỆU VÀ TỔNG QUAN TÀl LIỆU}

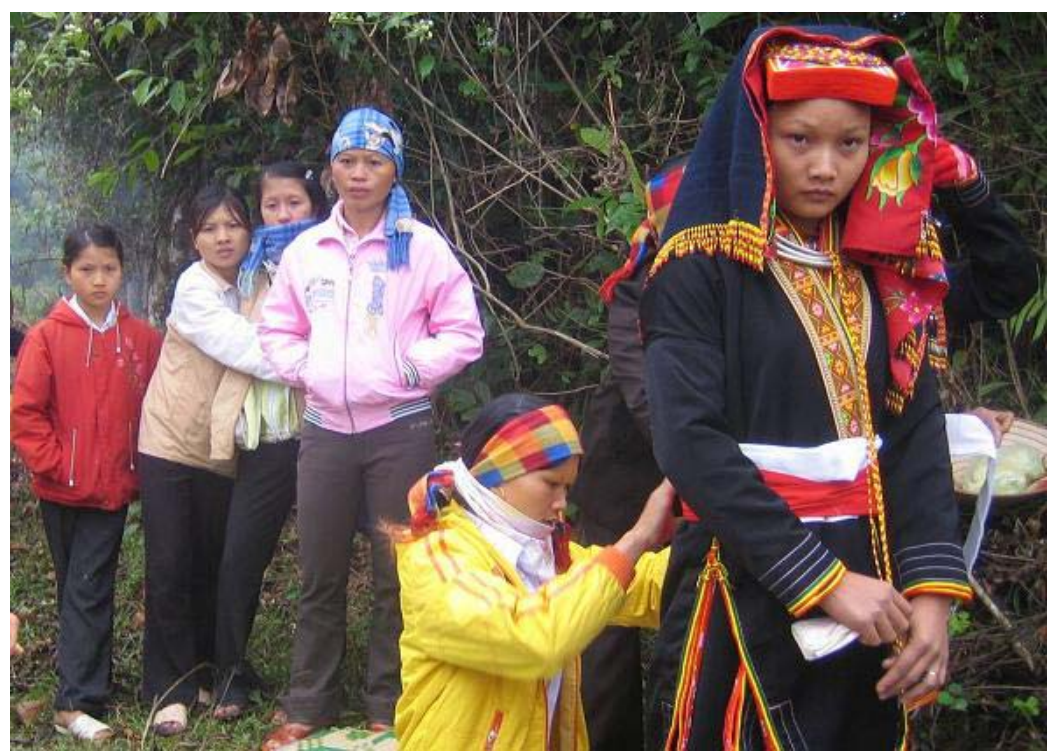

dink 1. Oân (không phải là tên thật), cồ gái người Dao, 19 tuổi ở một bản vìng sâu tỉnh Thái Xlguyên, Tang chuần bị cho tám cưới của mình.

\section{Giới thiệu}

Hôm nay là ngày trọng đại của Vân - ngày cưới. Cô gái người Dao 19 tuổi đang rất lo lắng không chỉ vì nhiều người đang nhìn cô trang điểm mà còn vì lần đầu tiên trong cuộc đời cô sẽ sống xa bố mẹ nơi cô đã sinh ra và lớn lên. Cha mẹ cô cho rằng cô đã đến tuổi lấy chồng. Trong một hoặc hai năm tới cô sẽ làm mẹ. Sau đó Vân và chồng cô cũng là người Dao có thể làm nhà riêng, có ruộng vườn riêng và sẽ có những đứa con như những thế hệ trước. Nếu mọi chuyện suôn sẻ, họ có thể vượt ra khỏi vòng đói nghèo của cha mẹ và thế hệ ông bà đã trải qua nhiều thập kỷ trước đây. Vân không chắc rằng phần tiếp theo của cuộc đời phụ nữ đã có chồng sẽ giống như một phần cuộc đời cha mẹ cô đã trải qua, mặc dù cuộc đời của cô là minh chứng cho nhiều sự thay đổi trong thời gian gần đây. 
Cũng như Vân, nhiều thanh niên ở miền núi Việt Nam, đặc biệt thanh niên các dân tộc thiểu số đang phải đối mặt với một tương lai không thể lường trước, chẳng hạn như sự phát triển kinh tế nhanh chóng của đất nước đã khiến cho đường, điện, xe máy và ti vi đến với làng quê của họ trong hơn hai năm qua. Một vài người bạn của Vân đã đi xuất khẩu lao động ở Malaysia để người vợ trẻ và những đứa con ở nhà. Một người khác đã thuyết phục được gia đình bán trâu - một trong những tài sản có giá trị lớn - để có tiền tìm việc trong một nhà máy ở miền Nam. Những người khác cố gắng vay tiền đầu tư vào việc nuôi lợn. Vân và những người bạn ở lứa tuổi của cô đang cố gắng để hiểu và theo kịp những thay đổi nhanh chóng dường như không ngờ để giành lấy những may mắn do sự thay đổi này mang lại.

Sự hội nhập và phát triển nhanh chóng của Việt Nam trên thị trường thế giới đã mang lại cho người Việt Nam ngày nay những cơ hội cũng như những nguy cơ không có ở thế hệ cha mẹ họ. Những nghiên cứu trên quy mô quốc gia gần đây đã mô tả tổng thể và sinh động bức tranh lạc quan sự phát triển con người của thanh niên dân tộc thiểu số Việt Nam. Tuy nhiên nghiên cứu cũng chỉ ra rằng thanh niên dân tộc thiểu số Việt Nam ở vùng sâu là ở nhóm "nghèo nhất, sức khoẻ kém nhất và hưởng thụ giáo dục thấp nhất" nhưng dù sao, họ cũng được chuẩn bị để thành công trong cuộc sống của họ (11). Chính phủ Việt Nam nhấn mạnh coi việc cung cấp các dịch vụ y tế và giáo dục đối với nhóm người này là chìa khoá của chương trình phát triển giai đoạn 2006-2010 (13).

Thanh niên dân tộc thiểu số chiếm $15 \%$ trong 84 triệu dân của Việt Nam. Với tỷ lệ sinh cao hơn so với người Kinh, đây là nhóm dân tộc phát triển nhanh nhất trong các dân tộc ở Việt Nam. Trong điều tra mức sống hộ gia đình Việt Nam năm 2004 và 2005, $61 \%$ dân tộc thiểu số Việt Nam là người nghèo (15), trong số khoảng 3 triệu người người dân tộc thiểu số nằm trong độ tuổi từ 14 đến 25 , có khoảng 2 triệu thanh niên dân tộc thiểu số là người nghèo. Nhiều người trong số họ đã hoặc sẽ giữ vai trò quan trọng trong việc phát triển kinh tế gia đình và thực hiện chức năng sinh sản của người trưởng thành. Một số người sẽ vượt ra ngoài làng quê vùng sâu, vùng xa của họ để tìm kiếm việc làm hoặc những cơ hội khác, để lại quê hương gia đình và người thân.

Để đề xuất chương trình can thiệp nhằm tăng cường sức khoẻ cho nhóm thanh niên dân tộc thiểu số và để họ thoát khỏi cảnh đói nghèo như cha mẹ họ một cách có hiệu quả, rất cần có hiểu biết đầy đủ về sự dịch chuyển lao động khi đến tuổi trưởng thành của thanh niên. Có những bằng chứng cho thấy mặc dù Nhà nước đã chú ý và nỗ lực xoá đói giảm nghèo trong những năm gần đây nhưng nhóm dân tộc thiểu số ở miền núi vẫn còn nghèo trong khi mức sống của người Kinh sống gần với họ đã được cải thiện. Nghiên cứu này sẽ so sánh trực tiếp mức sống giữa dân tộc thiểu số và dân tộc Kinh sống cùng hoàn cảnh trong các xã vùng sâu, có triển khai chương trình xoá đói giảm nghèo. Nghiên cứu này còn nhằm tìm hiểu một cách cặn kẽ sự khác nhau trong cách kiếm sống và những cố gắng để giảm nghèo của thanh niên và gia đình họ giữa 
dân tộc Kinh và dân tộc thiểu số. Nghiên cứu cũng cố gắng để chỉ ra những điều kiện có thể giúp thanh niên được hưởng lợi ích khi nắm được những cơ hội trong đời sống xã hội, kinh tế và văn hoá để tránh cho họ không bị tách khỏi nhịp phát triển của xã hội và bị bỏ lại phía sau.

Chúng tôi nghiên cứu quá trình phát triển đến tuổi trưởng thành, nguyên nhân và kết quả của sự phát triển này thông qua nghiên cứu thực địa. Nghiên cứu đã kết hợp các cách tiếp cận như phối hợp phân tích định tính và định lượng dựa trên số liệu phong phú từ điều tra dân số, điều tra hộ gia đình; phỏng vấn sâu thanh niên cùng cha mẹ họ và những người lãnh đạo ở địa phương. Nghiên cứu này cố gắng thảo luận về sự phát triển đến tuổi trưởng thành một cách hệ thống bằng cách xét mối quan hệ giữa việc chuẩn bị về giáo dục, sự phát triển, quá trình tìm kiếm việc làm, việc kết hôn, trở thành cha mẹ và sức khoẻ sinh sản. Chúng tôi cũng nhận ra sự khác biệt rất lớn về giá trị và hành vi giữa các nhóm dân tộc, đặc biệt là sự thích nghi với cuộc sống đang diễn ra. Để tránh đồng nhất giữa các nhóm dân tộc, nghiên cứu này đánh giá và so sánh sự phát triển sang tuổi trưởng thành giữa người Kinh và hai nhóm dân tộc: Dao và H'mong.

Mục tiêu của nghiên cứu này là đề xuất những chính sách phù hợp về sự chuyển đổi khi đến tuổi trưởng thành của thanh niên Việt Nam từ 15 đến 29 tuổi ở miền núi phía Bắc Việt Nam. Thứ nhất, nghiên cứu này cố gắng đánh giá mức độ thay đổi và những yếu tố quyết định sự thay đổi của thanh niên về 1) Sự chuẩn bị về giáo dục; 2) Quá trình chuyển đổi từ học hành đến lao động; 3 ) Kết hôn và trở thành cha mẹ và 4) Tình dục và sức khoẻ sinh sản. Ngoài ra, nghiên cứu này còn có mục đích chứng minh thành quả của sự thay đổi về phúc lợi, nghề nghiệp cho thanh niên và gia đình của họ.

\section{Chương trình xóa đói giảm nghèo và sự kém phát triển của người dân tộc thiểu số}

Trong những thập kỷ vừa qua, chính phủ Việt Nam đã thực hiện nhiều chính sách và chương trình giúp đỡ nhằm cải thiện mức sống và giảm nghèo cho nhóm dân tộc thiểu số. Hai chính sách chính về giảm nghèo là chương trình xoá đói giảm nghèo và chương trình 135.

Chương trình xoá đói giảm nghèo chính thức thực hiện vào năm 1998, chương trình có một bộ máy làm việc điều phối từ cấp trung ương đến tỉnh, huyện và xã với mục tiêu đầu tư cho xã hội và cung cấp các dịch vụ (chính phủ Việt Nam 1998a). Ba thành tố cơ bản của chương trình này là cung cấp dịch vụ miễn phí về y tế, giáo dục và tín dụng cho những hộ nghèo.

Cùng thời gian ra đời của chương trình xoá đói giảm nghèo, chương trình 135 chú trọng việc phát triển cơ sở hạ tầng cho các làng xã (đường, điện, nước sạch, cơ sở y tế) và hỗ trợ cho phát triển nông nghiệp ở những vùng được xác định là nghèo nhất và khó 
khăn. Trong năm 2005, chương trình 135 đã tiến hành tại 2.347 xã trong 52 tỉnh của Việt Nam. Chương trình 135 hiện tại đang ở giai đoạn II và có một số sự thay đổi.

\section{Khung 1.1 Sụ thay đổi của chương trình 135}

Giai đoạn II của chương trình 135 (2006-2010) đang thục hiện. Đích của giai đoạn II là 1.644 xã nghèo ở vùng núi của 45 tỉnh nơi tập trung phần lớn dân tộc thiểu số Việt Nam. Ngân sách cho chương trình này khoảng 800 triệu đô la Mỹ, chi cho 4 lĩnh vục: cơ sở hạ tầng co bản, sản phẩm nông nghiệp có định hướng thị trường và cải thiện cuộc sống văn hoá xã hội thông qua việc tiếp cận tốt hơn với các dịch vụ xã hội và nâng cao năng lục cho chính quyền tất cả các cấp. Uỷ ban Dân tộc Miền núi Việt Nam là cơ quản chủ quản được phân công điều phối và giám sát với sụ tham gia của nhiều bộ ngành liên quan. Chương trình tiến hành ở cấp huyện và xã dưới sụ chỉ đạo của các tỉnh.

Mục tiêu giai đoạn II của chương trình 135 bao gồm tăng cường sản xuất một cách triệt để, tăng cường chuyển đổi cơ cấu nông nghiệp theo hướng thị trường; cải thiện một cách bền vững điều kiện sống về vật chất và tinh thần của người dân tộc thiểu số đặc biệt ở những làng, xã thục sụ khó khăn và thu hẹp khoảng cách trong sự phát triển giữa các nhóm dân tộc thiểu số và giữa các vùng khác nhau.

Mục đích cụ thể cần đạt đến năm 2010 là:

Không còn hộ nghèo đói ở những xã có thục hiện chương trình. Trên 70\% các hộ gia đình có thu nhập bình quân đầu người trên 3,5 triệu đồng/năm.

80\% các xã vùng 135 có đường đến trung tâm xã, trên $80 \%$ các xã có hệ thống thuỷ lợi nhỏ để tưới tiêu được 85\% diện tích đất canh tác; $100 \%$ các xã có trường học, lớp học và phân hiệu để đáp úng nhu cầu học tập của nhân dân địa phương; $80 \%$ các xã có điện sinh hoạt cho người dân; 100\% các xã có trạm y tế xã với đầy đủ cơ sở vật chất.

Trên $80 \%$ các hộ gia đình có nước sạch; phòng và kiểm soát được các bệnh gây dịch; trên $50 \%$ hộ gia đình có hố xí; trên $95 \%$ trẻ em đến trường tiểu học đúng tuổi và $75 \%$ tiếp tục học ở các trường trung học cơ sở; trên 95\% người dân khi cần nhận được sụ hỗ trợ của luật pháp miễn phí.

Chương trình 135 giai đoạn II gồm có sụ đổi mới một cách đa dạng dựa trên những bài học kinh nghiệm khi tiến hành giai đoạn I và những chương trình xoá đói giảm nghèo khác ở Việt Nam, bao gồm: 
Nhấn mạnh vào sụ phân cấp với mục tiêu 100\% các xã có chương trình trở thành chủ đầu tư vào cuối giai đoạn II chương trình 135 năm 2010.

Ngân sách của chương trình với sụ phân bổ trục tiếp đến các xã dụa trên múc độ nghèo của họ và các tiêu chí khác do các tỉnh đưa ra.

Tăng cường sụ chuyển giao quản lý tài sản cho chính quyền địa phương, bao gồm báo cáo tài chính hàng quí, hồ sơ theo dõi tài chính và tăng cường kiểm toán.

Nguồn: Trung tâm tổ chúc phi chính phủ. 2006. Chương trình phát triển kinh tế xã hội cho dân tộc thiểu số và chương trình 135 miền núi giai đoạn ॥: Tổng quan về chương trình. Hà Nội. Việt Nam.

Trong khi kinh tế Việt Nam phát triển nhanh chóng, cùng với các chương trình cho người nghèo theo vùng địa lý chẳng hạn chương trình 135 và xóa đói giảm nghèo, Nhà nước đã thực hiện những chính sách giảm nghèo riêng cho các dân tộc thiểu số. Năm 1993, 86\% dân tộc thiểu số Việt Nam sống ở mức nghèo, năm 2002, còn dưới $70 \%$ được xác định hộ nghèo (15). Các nhà nghiên cứu đã chỉ ra rằng việc giảm nghèo ở các dân tộc thiểu số giữa các vùng miền khác nhau có những cảnh sống trong nghèo đói rất đa dạng đặc biệt ở những vùng sâu. Chỉ người Khmer ở phía Nam và vài dân tộc khác như Tày, Nùng sống trên vùng núi cao phía Bắc đã nhận được sự giúp đỡ có hiệu quả từ những năm 1990. Mức sống của hầu hết các dân tộc thiểu số ở vùng cao và người H’mong ở vùng núi phía Bắc đặc biệt vùng Tây Bắc vẫn còn thấp $(5,15)$.

Hình 1. Nghèo ở các dân tộc thiểu số miền núi vùng sâu Việt Nam

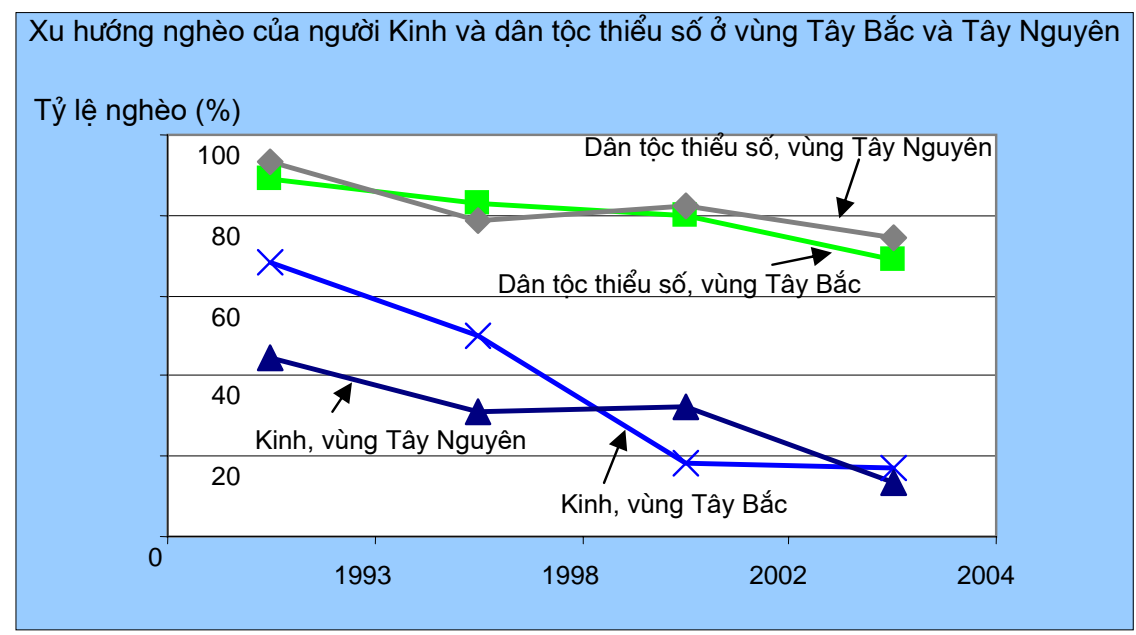

Nguồn: Swinkels và Turk (2006), dựa trên VLSS 1993, 1998 và VHLSS 2002, 2004. 
Biểu đồ trên cho thấy khoảng cách giàu nghèo giữa người Kinh và các dân tộc thiểu số còn khá xa. Trong khuôn khổ nguồn lực cho vùng nghèo, người Kinh tỏ ra có kinh nghiệm nâng cao mức sống nhanh hơn người dân tộc khác. Ở vùng Cao nguyên và Tây bắc số người Kinh nghèo đã giảm xuống một cách có ý nghĩa từ năm 1993 đến 2004 khiến tỷ lệ đói nghèo giảm nhanh hơn nhóm dân tộc thiểu số cùng sống ở vùng sâu (Hình 1). Hơn nữa, đánh giá định tính đã cho thấy mặc dù cơ sở vật chất mới trang bị cho vùng sâu không phải là ít nhưng những người dân tộc thiểu số có thể không có cơ hội để tiếp cận và sử dụng những cơ sở vật chất này (4). Khi tổng tỷ lệ nghèo ở Việt Nam giảm xuống còn khoảng $20 \%$ trong tổng dân số vào năm 2010, tỷ lệ người nghèo trong nhóm dân tộc thiểu số sẽ tăng lên. Vào năm 2010, cứ 10 người nghèo sẽ có 4 người thuộc dân tộc thiểu số (21).

Chương trình 135 và xoá đói giảm nghèo đã có một số thành công, đặc biệt việc cải thiện cơ sở hạ tầng. Tuy nhiên, các chương trình này cũng bị phê phán vì chủ yếu chỉ chú ý đến việc xây dựng cơ sở hạ tầng mà không chú ý đến cải thiện cách kiếm sống của người dân. Ví dụ, hoạt động đầu tư chương trình 135 về sản xuất nông nghiệp chú trọng vào hỗ trợ về kỹ thuật và chi trả một phần nhỏ cho bộ máy. Ngoài ra người ta còn phê phán sự thiếu minh bạch và không chú ý đầy đủ đến phát triển năng lực cho người dân địa phương. Ngoài ra, đánh giá trong những năm gần đây cho thấy chương trình xoá đói giảm nghèo đã triển khai không đồng bộ và không nhận được kinh phí đầy đủ để các dịch vụ được duy trì sau đó (21).

\section{Phúc lợi xã hội của thanh niên dân tộc thiểu số ở Việt Nam}

Nghèo đói kéo dài trong các nhóm dân tộc thiểu số do khó khăn và nghèo khổ từ khi còn nhỏ, những khó khăn này bao gồm cả thu nhập thấp và sức khoẻ kém. Trong khi trường tiểu học đã thu nhận được $80 \%$ học sinh dân tộc thiểu số vào năm 2002 nhưng tỷ lệ học sinh bị lưu ban hoặc bỏ học trước lớp 6 khá cao (21). Nghèo và thiếu tiền để chi phí cho con em đến trường là lý do cơ bản để học sinh bỏ học. Ngoài ra còn những lý do khác không liên quan đến tài chính như khoảng cách từ nhà đến trường, ngôn ngữ và những rào cản về văn hoá. Mặc dù trường học đã được xây dựng với kinh phí từ chương trình 135 , nhưng còn thiếu nhiều lớp học và những giáo viên có thể sử dụng được tiếng địa phương (6).

Kết quả của điều tra đánh giá thanh niên Việt Nam năm 2003 cho thấy có một tỷ lệ lớn thanh niên dân tộc thiểu số không biết đọc biết viết. Khoảng cách về hưởng thụ giáo dục giữa nam và nữ của dân tộc thiểu số khá lớn. Các gia đình dân tộc thiểu số thường tập trung đầu tư cho con trai nhiều hơn con gái. Tỷ lệ học sinh dân tộc thiểu số từ trường tiểu học tiếp tục học trung học cơ sở thấp hơn tỷ lệ của học sinh người Kinh (6). Do những hạn chế về giáo dục và kỹ năng rất nhiều thanh niên dân tộc thiểu số vẫn 
còn làm nghề nông. Các sản phẩm nông nghiệp phần nào còn ít bởi người dân tộc thiểu số có xu hướng nhận những phần ruộng nhỏ đã làm lâu năm. So sánh với người Kinh, người thiểu số có tỷ lệ rất nhỏ có thu nhập từ làm thuê hoặc kinh doanh phi nông nghiệp - hai ngành kinh tế được coi là mũi nhọn của Việt Nam (7).

Bảng 1. Sự chênh lệch về giáo dục của người Kinh và dân tộc thiểu số

\begin{tabular}{|c|c|c|c|c|c|c|c|}
\hline & \multirow{3}{*}{ Trình độ học vấn } & \multirow{2}{*}{\multicolumn{2}{|c|}{$\begin{array}{c}\text { Tuổi 14-17 } \\
\text { Dân tộc }\end{array}$}} & \multirow{2}{*}{\multicolumn{2}{|c|}{$\begin{array}{c}\text { Tuổi 18-21 } \\
\text { Dân tộc }\end{array}$}} & \multirow{2}{*}{\multicolumn{2}{|c|}{$\begin{array}{c}\text { Tuổi 22-25 } \\
\text { Dân tộc }\end{array}$}} \\
\hline & & & & & & & \\
\hline & & Kinh & Thiểu số & Kinh & Thiểu số & Kinh & Thiểu số \\
\hline Nam & \% Đã từng đến trường & 99 & 97 & 98 & 89 & 97 & 86 \\
\hline & \% Mù chữ & 2 & 7 & 4 & 17 & 6 & 26 \\
\hline Nữ & \% Đã từng đến trường & 99 & 89 & 99 & 76 & 97 & 67 \\
\hline & \% Mù chữ & 2 & 18 & 2 & 30 & 4 & 43 \\
\hline
\end{tabular}

Nguồn: Đánh giá điều tra thanh niên Việt Nam 2003

Bảng 2. Phân chia theo tuổi đến trường của học sinh ở từng cấp

\begin{tabular}{|c|c|c|c|}
\hline \multirow[t]{2}{*}{ Nhóm dân tộc } & \multicolumn{3}{|c|}{$\begin{array}{l}\text { Học tiểu học } \\
\text { Tỷ lệ năm 1999* }\end{array}$} \\
\hline & Tổng số & Nam & Nũ \\
\hline Kinh & 93.4 & 93.5 & 93.4 \\
\hline Hoa & 93.7 & 94.5 & 92.9 \\
\hline Khmer & 76.3 & 77.3 & 75.3 \\
\hline \multicolumn{4}{|l|}{ Trung du } \\
\hline Gia rai & 66.4 & 67.6 & 65.1 \\
\hline Ba-na & 57.8 & 55.0 & 60.4 \\
\hline Xo-dang & 62.2 & 64.7 & 59.3 \\
\hline \multicolumn{4}{|l|}{ Miền núi phía Bắc } \\
\hline Tay & 94.7 & 94.9 & 94.4 \\
\hline Thai & 83.9 & 87.2 & 80.5 \\
\hline Muong & 94.5 & 94.9 & 94.0 \\
\hline Nung & 89.3 & 89.7 & 88.9 \\
\hline Hmong & 41.5 & 51.5 & 31.5 \\
\hline Dao & 71.4 & 73.7 & 68.8 \\
\hline
\end{tabular}

Ghi chú: Tỷ lệ đến trường = tổng số đến trường $x$ số trẻ đúng tuổi ở từng cấp

Nguồn: Baulch và cộng sự. (2004), dựa trên 3\% mẫu điều tra dân số năm 1999 
Những khó khăn về điều kiện kinh tế - xã hội của thanh niên Việt Nam còn phức tạp hơn bởi liên quan đến sức khoẻ kém. Mức độ suy dinh dưỡng ở người Việt Nam cho thấy có sự khác biệt rất lớn giữa trẻ em dân tộc thiểu số và dân tộc Kinh (5). 1/3 trẻ em dân tộc ở miền núi phía bắc, trên $2 / 5$ trẻ ở miền biển và cao nguyên bị suy dinh dưỡng (10). Suy dinh dưỡng xuất hiện và ảnh hưởng đến tuổi trưởng thành. So với người Kinh, thanh niên dân tộc thiểu số từ 14 đến 25 có triệu chứng của bệnh tật, ốm đau trong thời gian ngắn và cảm thấy quá mệt mỏi khi đi học hoặc làm việc trong thời gian dài.

Bảng 3. Thống kê chung về tình trạng sức khoẻ của thanh niên người Kinh và dân tộc thiểu số

\begin{tabular}{|c|c|c|c|c|c|c|c|}
\hline & \multirow{3}{*}{ Ốm đau } & \multirow{2}{*}{\multicolumn{2}{|c|}{$\begin{array}{c}\text { Tuổi 14-17 } \\
\text { Dân tộc }\end{array}$}} & \multirow{2}{*}{\multicolumn{2}{|c|}{$\begin{array}{c}\text { Tuổi 18-21 } \\
\text { Dân tộc }\end{array}$}} & \multirow{2}{*}{\multicolumn{2}{|c|}{$\begin{array}{c}\text { Tuổi 22-25 } \\
\text { Dân tộc }\end{array}$}} \\
\hline & & & & & & & \\
\hline & & Kinh & Thiểu số & Kinh & Thiểu số & Kinh & Thiểu số \\
\hline \multirow[b]{2}{*}{ Nam } & \% Bị ốm trong tháng vừa qua & 38 & 48 & 34 & 38 & 30 & 42 \\
\hline & $\begin{array}{l}\text { \% Cảm thấy rất mệt khi đi trường } \\
\text { hoặc đi làm trong năm vừa qua }\end{array}$ & 40 & 47 & 36 & 48 & 38 & 51 \\
\hline \multirow[b]{2}{*}{ Nữ } & \% Bị ốm trong tháng vừa qua & 46 & 56 & 45 & 58 & 43 & 57 \\
\hline & $\begin{array}{l}\text { \% Cảm thấy rất mệt khi đi trường } \\
\text { hoặc đi làm trong năm vừa qua }\end{array}$ & 34 & 50 & 37 & 54 & 34 & 56 \\
\hline
\end{tabular}

Nguồn: Đánh giá điều tra thanh niên Việt Nam năm 2003

Trong những năm vừa qua có rất nhiều cuộc thảo luận về việc xuất hiện những nguy cơ mới cho sức khoẻ do tập quán văn hoá của các dân tộc thiểu số cùng với những khó khăn trong việc tiếp cận với các dịch vụ chăm sóc sức khoẻ tình dục và sức khoẻ sinh sản. Những dịch vụ này được quan tâm đặc biệt là đại dịch HIV/AIDS ở Việt Nam. Kết quả nghiên cứu của SAVY năm 2003 cho thấy tình dục trước hôn nhân của nữ thanh niên Việt Nam vẫn còn thấp, nữ dân tộc thiểu số ở độ tuổi 18-25 có quan hệ tình dục trước hôn nhân nhiều hơn người Kinh cùng lứa tuổi (hình 2). Một nghiên cứu định tính giữa người H'mong, Dao, Thái và Khmer chỉ ra những sinh hoạt ở địa phương như chợ tình là nơi cho phép con người có thể gặp gỡ mà không có sự giám sát của người lớn có thể diễn ra quan hệ tình dục trước hôn nhân (17). Mức độ chấp nhận quan hệ tình dục trước hôn nhân rất khác nhau giữa các nhóm dân tộc. Ví dụ quan hệ tình dục trước hôn nhân ở người H'mong ít bị kỳ thị hơn người Dao, Thái và Khmer. Trong hành vi quan hệ tình dục trước hôn nhân giữa các nhóm dân tộc thiểu số, nghiên cứu SAVY 
2003 cho thấy kiến thức về các phương pháp tránh thai hiện đại của thanh niên dân tộc thiểu số từ 14-25 vẫn còn kém hơn so với người Kinh ${ }^{1}$.

\section{Hình 2. Hành vi tình dục trước hôn nhân của thanh niên trong độ tuổi 14 đến 25} theo giới, dân tộc và độ tuổi

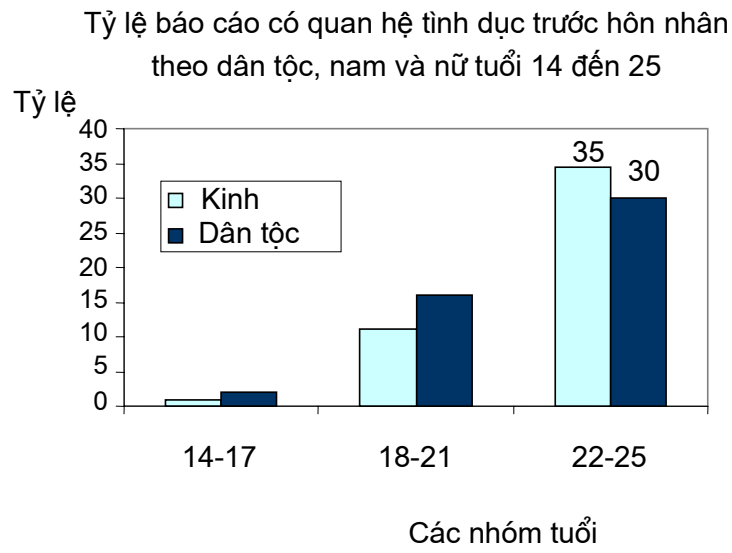

Tỷ lệ báo cáo có quan hệ tình dục trước hôn nhân

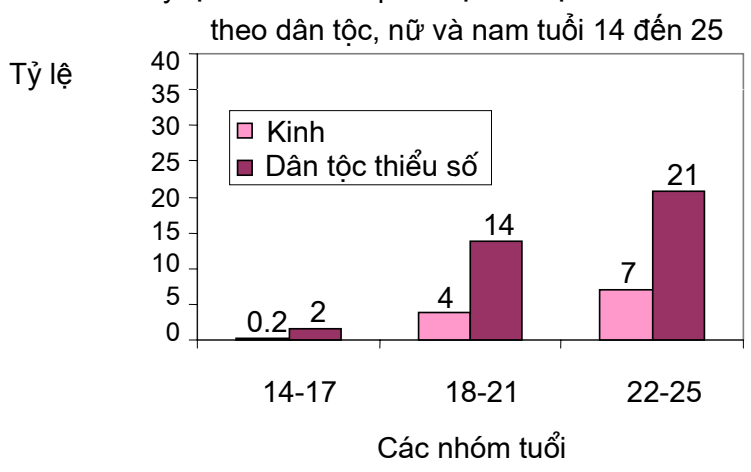

Nguồn: Điều tra đánh giá thanh niên Việt Nam năm 2007

Hành vi tình dục trước hôn nhân, xu hướng kết hôn sớm của người dân tộc thiểu số đặt ra một vấn đề cần quan tâm khác về sức khoẻ sinh sản của phụ nữ dân tộc thiểu

1 Báo cáo SAVY năm 2003 không cung cấp số liệu về tiếp cận với các phương tiện tránh thai của thanh niên dân tộc thiểu số, DHS năm 2002 tập trung vào những phụ nữ chưa kết hôn hoặc phụ nữ kết hôn hiện tại. Có thể so sánh với DHS, điều tra chỉ số AIDS và dân số Việt Nam do GSO, NIHE, và ORC Macro thực hiện tiến hành đối với cả những người đã kết hôn và chưa kết hôn. Số liệu chưa được công bố. 
số. Kết hôn sớm vẫn còn rất phổ biến ở nữ dân tộc thiểu số. Theo báo cáo của SAVY 2003, gần 70\% phụ nữ dân tộc thiểu số tuổi 20 đã kết hôn (bảng 4). 80\% trong số đó đã cưới khi họ còn đang hoặc mới qua tuổi vị thành niên (13-19 tuổi), một nửa số người kết hôn trong vòng ba năm sau khi có kinh lần đầu tiên. Mặc dù có thai trong giai đoạn đầu của tuổi thanh niên là hiện tượng không phổ biến trong các dân tộc thiểu số, việc sinh con gây ra những mối đe dọa cho sự an toàn của người mẹ. VNHS gợi ý rằng có $65 \%$ phụ nữ ở Tây Bắc và $40 \%$ phụ nữ ở vùng cao đẻ con tại nhà mà không có sự hỗ trợ của cán bộ y tế, cao hơn mức trung bình của cả nước $16 \%$. Các nguyên nhân chính gây ra hiện tượng này là khoảng cách từ nhà đến cơ sở y tế khá xa, cán bộ y tế xã thường là nam giới ở vùng sâu vùng xa (22). Năm 2002 tỷ lệ tử vong sơ sinh ở tuyến huyện ở miền núi cao gần gấp 2 lần so với mức trung bình của cả nước (14).

Bảng 4. Thời gian dậy thì, kết hôn và có con đầu lòng: phụ nữ từ 14 đến 25 theo vị trí địa lý và dân tộc.

\begin{tabular}{|c|c|c|c|c|c|c|}
\hline \multirow{2}{*}{ Nhóm tuổi và vùng địa lý } & \multicolumn{2}{|c|}{ Tổng số } & \multicolumn{2}{|c|}{ Những người kết hôn } & \multicolumn{2}{|c|}{$\begin{array}{l}\text { Những người kết hôn } \\
\text { và có con }\end{array}$} \\
\hline & $\begin{array}{c}\text { \% có kinh } \\
\text { nguyệt }\end{array}$ & $\begin{array}{l}\text { Tuổi dậy thì } \\
\text { trung bình }\end{array}$ & $\begin{array}{c}\text { Tỷ lệ } \\
\text { kết hôn }\end{array}$ & $\begin{array}{c}\text { Tuổi kết hôn } \\
\text { lần đầu }\end{array}$ & $\begin{array}{l}\text { Tỷ lệ } \\
\text { có con }\end{array}$ & $\begin{array}{l}\text { Tuổi trung bình } \\
\text { có thai lần đầu }\end{array}$ \\
\hline \multicolumn{7}{|l|}{ 1. Tuổi 14-17 } \\
\hline Thành phố lớn & $96 \%$ & $13.1(1.2)$ & $0.4 \%$ & * & * & * \\
\hline Thị trấn & $97 \%$ & $13.6(1.0)$ & $0.7 \%$ & * & * & * \\
\hline Vùng nông thôn - người Kinh & $86 \%$ & $13.9(1.0)$ & $0.5 \%$ & * & * & * \\
\hline Vùng nông thôn người dân tộc & $69 \%$ & $14.2(1.1)$ & $2 \%$ & * & * & * \\
\hline \multicolumn{7}{|l|}{ 2. Tuổi 18-21 } \\
\hline Thành phố lớn & $100 \%$ & $13.9(1.4)$ & $4 \%$ & * & * & * \\
\hline Thị trấn & $100 \%$ & $14.3(1.4)$ & $18 \%$ & * & * & * \\
\hline Vùng nông thôn - Kinh & $100 \%$ & $14.7(1.4)$ & $21 \%$ & * & * & * \\
\hline Vùng nông thôn người dân tộc & $100 \%$ & $14.9(1.4)$ & $42 \%$ & $17.9(1.5)$ & $68 \%$ & $18.6(1.3)$ \\
\hline \multicolumn{7}{|l|}{ 3. Tuổi $22-25$} \\
\hline Thành phố lớn & $100 \%$ & $14.2(1.5)$ & $25 \%$ & * & * & * \\
\hline Thị trấn & $100 \%$ & $14.6(1.5)$ & $45 \%$ & $20.7(2.1)$ & $81 \%$ & $21.5(2.2)$ \\
\hline Vưng nông thôn - Kinh & $100 \%$ & $15.2(1.6)$ & $63 \%$ & $20.3(1.8)$ & $90 \%$ & $21.1(1.7)$ \\
\hline Vùng nông thôn - người dân tộc & $100 \%$ & $155(17)$ & $81 \%$ & $18.9(22)$ & $8.9 \%$ & $19.9(20)$ \\
\hline
\end{tabular}

Nguồn số liệu: Đánh giá thanh niên Việt Nam năm 2003

Ghi chú: SD để trong ngoặc.

Dấu sao là những ước lượng có cỡ mẫu nhỏ nên không trình bày trong bảng này.

Nguy cơ lan truyền HIV/AIDS trong thanh niên dân tộc thiểu số chưa được xác định một cách rõ ràng. Tuy nhiên, nam thanh niên của một số dân tộc thiểu số có thể có nguy cơ vì tiền sử dùng thuốc phiện hoặc các chế phẩm của thuốc phiện (Ví dụ H'mong, Dao và Thái), kết hợp với tăng cường sử dụng heroin, nhận thức về HIV/AIDS chưa đầy đủ và tỷ lệ sử dụng bao cao su thấp. 
Nhiều nghiên cứu chỉ ra rằng thanh niên người Kinh có chỉ số phát triển con người tốt hơn thanh niên dân tộc thiểu số. Sự lan truyền nghèo đói từ thế hệ này sang thế hệ khác của dân tộc thiểu số khá rõ. Nhiều nhà nghiên cứu cho rằng nguyên nhân của nghèo đói là thiếu tài sản chẳng hạn như đất đai hay giáo dục có nhiều hạn chế, điều này có thể giải thích được sự nghèo đói kéo dài của họ. Những nguyên nhân khác đáng chú ý là điều kiện địa lý, phong tục của những người ở miền núi và thiếu nguồn vốn được cung cấp từ chính phủ. Thực tế chỉ ra rằng nếu những hộ dân tộc thiểu số có tài sản như những hộ người Kinh thì khoảng cách giàu nghèo giữa người Kinh và người dân tộc thiểu số sẽ không còn (5). Đời sống thấp kém đối với người dân tộc thiểu số có ít tài sản có thể giải thích do nhận thức, do phong tục tập quán hoặc do thiếu thông tin (18).

Cần lưu ý rằng không phải mọi dân tộc đều có khó khăn như nhau. Các nhóm dân tộc thiểu số hoà hợp về kinh tế và phong tục tập quán nhiều hơn với người Kinh thường có điều kiện sống tốt hơn (5). Dân tộc Tày và Nùng là những ví dụ, tỷ lệ hôn nhân với người khác dân tộc như người Kinh cao hơn. Nhóm dân tộc này cũng trải qua việc học hành và tình trạng sức khoẻ tương tự như người Kinh. Người Tày và Nùng cũng trải nghiệm và có tài sản tương tự như người Kinh. Hơn nữa, cũng có những nhóm dân tộc khác như Khmer và Thái (và có thể người Dao) giữ lại được những đặc trưng văn hoá của họ, không bị ảnh hưởng về kinh tế với người Kinh. Một phân tích về dân số năm 1999 chỉ ra rằng dân tộc thiểu số vùng cao và người H'mong ở miền núi phía Bắc ít kết hôn với người dân tộc khác. Họ cũng là những người nghèo nhất và có chỉ số phát triển con người thấp nhất so với các dân tộc thiểu số khác. "Liệu có phải đây là do vấn đề lựa chọn hay do hậu quả của rào cản về ngôn ngữ và vùng địa lý ?” (5).

\section{Mục tiêu nghiên cứu cụ thể}

So với những nghiên cứu trước đây chỉ dựa trên phương pháp đánh giá nhanh, nghiên cứu này cố gắng cung cấp thông tin có chiều sâu, một cách hệ thống về thanh

niên dân tộc thiểu số. Chúng tôi cũng cố gắng đóng góp những hiểu biết mới về những cơ hội và nguy cơ ảnh hưởng đến cuộc sống của thanh niên dân tộc thiểu số và những quyết định của họ trong việc đến trường, kiếm sống, tình dục, sức khoẻ sinh sản, kết hôn và hình thành gia đình. Mục tiêu nghiên cứu cụ thể như sau:

4.1. Tìm hiểu các chính sách theo vùng địa lý nhằm xoá nghèo như chương trình 135 và xoá đói giảm nghèo ảnh hưởng đến quyết định của thanh niên dân tộc thiểu số trong việc đến trường, việc làm, sức khoẻ sinh sản, hôn nhân và mô tả những kết quả do sự nỗ lực khác nhau của người Kinh và dân tộc thiểu số.

4.2. Mô tả xu hướng và mô hình giáo dục, bao gồm tiếp cận với giáo dục, chất lượng của trường học và hiểu được các yếu tố ảnh hưởng đến mô hình này giữa người Kinh và dân tộc thiểu số ở vùng sâu, vùng xa. 
4.3. Hiểu được mức độ thanh niên Việt Nam ở vùng sâu tiếp cận được với cơ hội có việc làm đặc biệt là các nghề phi nông nghiệp và việc di cư tới vùng thành thị.

4.4. Nghiên cứu sự khác nhau về kiến thức của thanh niên người Kinh và dân tộc thiểu số về tiếp cận với phương tiện tránh thai, kế hoạch hoá gia đình, làm mẹ an toàn và nạo phá thai.

4.5. Đề xuất các chính sách và chương trình can thiệp nhằm đảm bảo tăng cường sức khoẻ cho thanh niên ở vùng sâu, vùng xa Việt Nam. 


\section{Chương 2}

\section{PHƯƠNG PHÁP NGHIÊN CỨU}

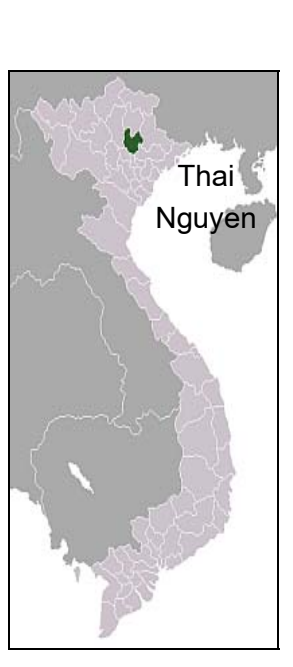

Source: Wikipedia

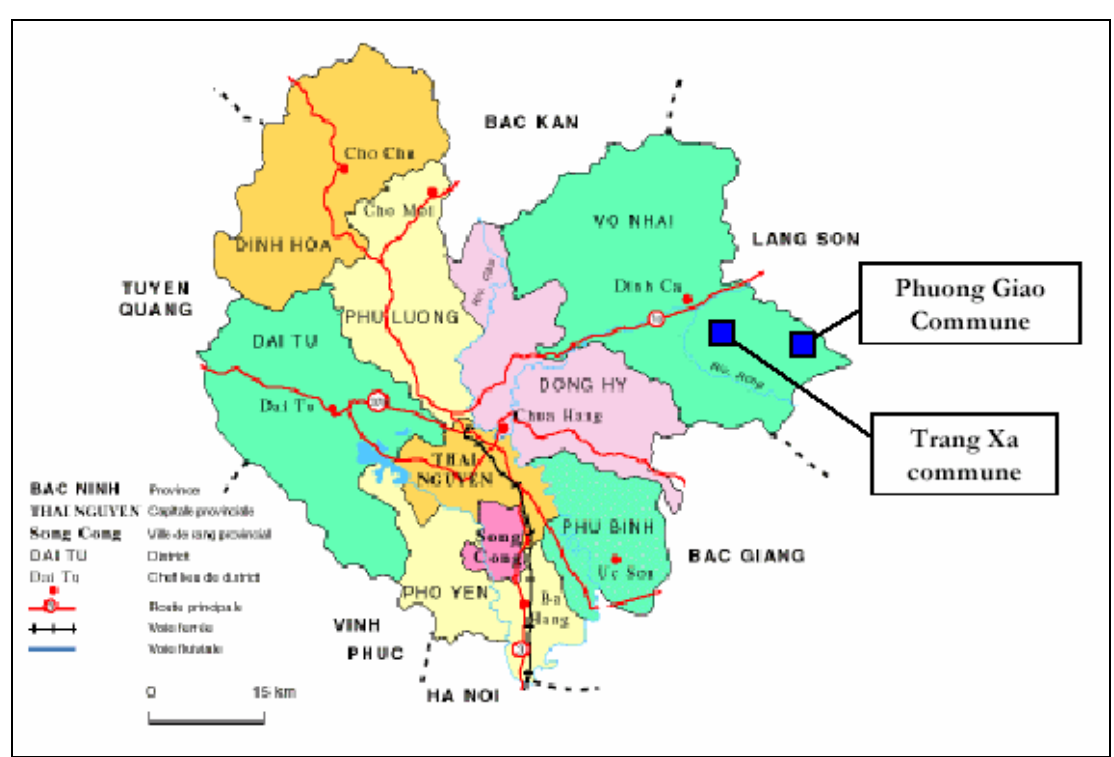

Hình 3. Vị trí của hai xã Phương Giao và Tràng Xá, huyện Võ Nhai, tỉnh Thái Nguyên (Hai địa điểm nghiên cứu được lựa chọn)

\section{Lựa chọn địa điểm}

Các cụm xóm thuộc vùng sâu, vùng xa huyện Võ Nhai, tỉnh Thái Nguyên đã được lựa chọn làm địa bàn nghiên cứu. Cụm thứ nhất ("Cụm A") bao gồm 5 xóm thuộc xã Phương Giao; cụm thứ hai ("Cụm B") bao gồm 4 xóm thuộc xã Tràng Xá. Có hai nhóm dân tộc thiểu số khác nhau tại hai cụm dân cư trên (Dao-Phương Giao; H'mong -Tràng Xá), ở hai khu vực tiếp giáp nhau. Có 6 dân tộc sống khu vực này, trong đó có cả 2 nhóm dân tộc Dao và $H$ 'mong. Ở cả hai xã người Dao và H'mong sống cùng với một số ít hộ gia đình là dân tộc Kinh. Các xóm được chọn vào mẫu nghiên cứu tiêu biểu cho nền kinh tế khu vực nông thôn miền núi, vùng sâu vùng xa của các tỉnh phía Bắc. Cả hai cụm dân cư $\mathrm{A}$ và $\mathrm{B}$ trong mẫu nghiên cứu đều nằm trong chương trình xóa đói giảm 
nghèo. Trong vòng 5 năm qua ở đây đã có các dự án xây dựng cơ sở hạ tầng khác nhau bao gồm hệ thống đường giao thông đi lại và mạng lưới điện sinh hoạt. Người dân nơi đây không quá nghèo nhưng cũng không khá giả do điều kiện sản xuất nông nghiệp, xa chợ, cũng như hạn chế về kỹ thuật.

Có một số điểm giống nhau cũng như khác nhau giữa cụm dân cư $\mathrm{A}$ ở Phương Giao và $\mathrm{B}$ ở Tràng Xá về thành phần dân tộc, khả năng tiếp cận, các sản phẩm nông nghiệp, cơ cấu nghề nghiệp, tỷ lệ tăng dân số cũng như trình độ văn hóa giáo dục. Người Kinh sống ở cả hai khu vực dân cư này. Người Dao được chọn trong mẫu nghiên cứu của chúng tôi trong 2 xóm của khu vực $\mathrm{A}$. Trong khi đó, hầu như những người H'mong trong mẫu nghiên cứu sống tập trung trong cùng một xóm ở khu vực B. Tại địa bàn nghiên cứu, phần lớn người Kinh sống trong cùng mét xóm - thường cùng một số ít người Tày, Nùng nhưng đối tượng nghiên cứu chủ yếu là người Kinh, Dao và H'mong.

Tất cả các xóm khu vực $A$ và $B$ đều là "khu vực vùng sâu, vùng xa" theo tiêu chí phân loại của địa phương. Địa bàn nghiên cứu cách xa trung tâm xã từ 6 đến $16 \mathrm{~km}$. Các xóm dân tộc thiểu số ở xa hơn các xóm dân tộc Kinh. Một nghiên cứu sâu tại hai khu vực này có thể được coi như một nghiên cứu cơ bản cho các công việc tiếp theo là xác định sự khác biệt của các nhóm dân tộc thiểu số do tác động của chương trình xóa đói giảm nghèo và đời sống của thanh niên cùng với gia đình họ.

\section{Thu thập số liệu}

Phương pháp nghiên cứu định tính được áp dụng là phương pháp chính, tuy nhiên phương pháp nghiên cứu định lượng cũng được áp dụng như dựa vào sổ sách thống kê và điều tra hộ gia đình. Trong tháng 6 và tháng 7 năm 2006, các nghiên cứu viên của Hội đồng Dân số và Trường Đại học $\mathrm{Y}$ khoa Thái Nguyên đã tiến hành khảo sát thực địa. Sau khi 2 cụm dân cư được lựa chọn làm mẫu nghiên cứu, các hoạt động tại thực địa được tiến hành từ tháng 9 đến tháng 12 năm 2006. Mỗi xóm ở hai cụm được đến thăm và tìm hiểu thông tin 3 lần, thời gian mỗi đợt khoảng 5 ngày. Trong mỗi lần đến thăm hộ gia đình, các nghiên cứu viên thực hiện thu thập các loại thông tin khác nhau.

Nhóm nghiên cứu đã thu thập số liệu điều tra cộng đồng và thống kê dân số của hộ gia đình ở các xóm tại hai khu vực nghiên cứu. Theo kết quả đánh giá và thống kê, tổng số hộ điều tra là 150 hộ gia đình (75 hộ trong mỗi cụm xóm) nội dung được điều tra là điều kiện sống, sinh hoạt cũng như kinh tế. Thêm vào đó, 60 hộ trong số 150 hộ gia đình được lựa chọn để tiến hành phỏng vấn sâu. Một trong các tiêu chí cơ bản để chọn hộ gia đình là ít nhất có một thành viên trong gia đình nằm trong độ tuổi 15 đến 29. Mục đích của chúng tôi là phỏng vấn thanh niên và cha hoặc mẹ họ (cùng giới). Sự lựa chọn mẫu nghiên cứu đảm bảo nhóm được phỏng vấn cân bằng về giới, dân tộc: Kinh, Dao, H’mong, các đối tượng chưa và đã lập gia đình. 
Nhóm nghiên cứu đến thăm 60 hộ gia đình, mỗi hộ 2 lần, khoảng cách giữa lần đến thăm để phỏng vấn đối tượng là 4-6 tuần. Trong lần đến thăm thứ nhất cán bộ nghiên cứu đã tiến hành cuộc phỏng vấn sâu thanh niên trong độ tuổi nghiên cứu, danh sách được lựa chọn ngẫu nhiên trong số các đối tượng phù hợp với tiêu chí lựa chọn. Mỗi cuộc phỏng vấn kéo dài khoảng 90 phút. Nhóm nghiên cứu đã thực hiện phỏng vấn theo giới, người được phỏng vấn và người phỏng vấn cùng giới. Trong lần đến thăm tiếp theo, hầu hết các đối tượng thanh niên trong mẫu nghiên cứu được phỏng vấn lại với người đã phỏng vấn trước đây vì thế hệ cha mẹ họ. Tuy nhiên nhóm nghiên cứu cũng đã có gắng để phỏng vấn một cách ngẫu nhiên thanh niên sống ở ngoài làng trong thời gian nghiên cứu. Ví dụ: chúng tôi đã phỏng vấn 5 học sinh đang học ở trường trung học phổ thông Đình Cả và một phụ nữ đang làm việc tại một nhà máy ở thành phố Thái Nguyên.

Về ngôn ngữ, mặc dù người Dao và H'mong thường nói tiếng dân tộc mình ở nhà nhưng hầu hết những người dân tộc thiểu số tại các xóm trong địa bàn nghiên cứu đều hiểu được tiếng Kinh trừ nhiều người cao tuổi. Nhóm nghiên cứu thấy hầu hết thanh niên (cả nam và nữ) ở lứa tuổi trung niên đều có thể giao tiếp bằng tiếng Kinh, tuy cũng có khó khăn đôi chút. Điều này không đúng với phụ nữ lớn tuổi, họ ít biết tiếng Kinh hơn nhiều. Người dân tộc thiểu số có thể nói được tiếng Kinh là do họ sống gần với các xóm dân tộc Kinh, họ học được qua trao đổi mua bán hàng hóa, các sản phẩm nông nghiệp, chăn nuôi và tiếp cận với các phương tiện truyền thông. Trong một số trường hợp khi họ không hiểu và không thể diễn đạt được bằng tiếng Kinh nhóm nghiên cứu đã đề nghị những người dân thạo tiếng Kinh tại các bản dân tộc Dao hoặc H'mong giúp đỡ làm phiên dịch trong các cuộc phỏng vấn.

\section{Mô tả số liệu}

\subsection{Phân tích cộng đồng}

Việc phân tích cộng đồng đã mang lại cái nhìn tổng quan về tình hình dân số, kinh tế - xã hội của từng xóm trong hai cụm dân cư hai xã Tràng Xá và Phương Giao thuộc địa bàn nghiên cứu đã lựa chọn. Những phân tích này giúp đánh giá các đặc điểm dân số của nhóm dân tộc thiểu số, các chỉ số tiếp cận của các xóm, các sản phẩm và thu nhập chính cùng các hoạt động phát triển kinh tế, xã hội liên quan giữa nhóm dân tộc Kinh và nhóm dân tộc thiểu số và những sinh hoạt văn hóa của mỗi dân tộc. Nó cũng cung cấp những thông tin về việc chính quyền xóm tham gia vào chương trình xóa đói giảm nghèo, đặc biệt việc hình thành những quyết định, cách phân bổ chương trình và nhận thức của người lãnh đạo tại địa phương tác động như thế nào đến đời sống của người dân trong khu vực này. 


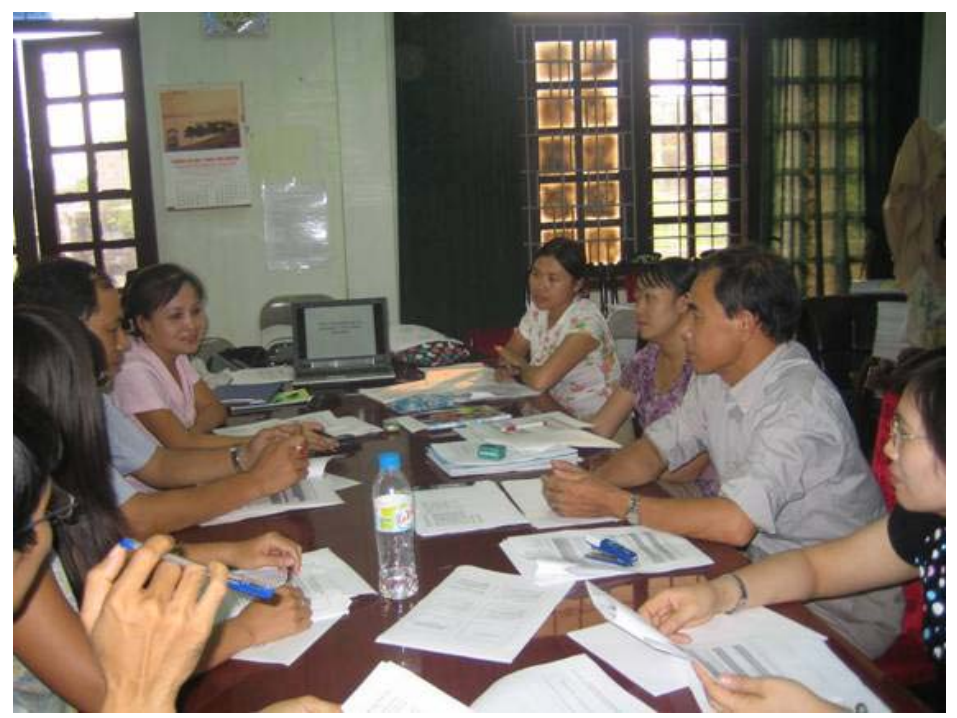

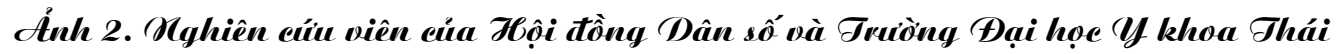 Dguyên trong buối thảo luận về kế hoụch làm vị̣̂e tại thụic tịa.}

Đối tượng cung cấp số liệu sử dụng đánh giá cộng đồng là cán bộ ủy ban nhân dân xã, trưởng bản, bác sỹ tại trạm y tế, cộng tác viên dân số và giáo viên các trường tiểu học và trung học cơ sở. Việc đánh giá cũng được thực hiện bằng phương pháp vẽ bản đồ các xóm do các trưởng xóm thực hiện. Bản đồ được minh họa bởi các đường giáp ranh các xóm trong xã và giữa các xã, những địa điểm nổi bật trong xóm, hệ thống đường giao thông và sự phát triển cơ sở hạ tầng tại mỗi xóm. Những minh họa như vậy đã giúp đánh giá khả năng tiếp cận và điều kiện địa lý cũng như xã hội, mức độ xa xôi hẻo lánh của các xóm trong địa bàn nghiên cứu tại huyện Võ Nhai.

\subsection{Thống kê dân số}

Việc thống kê các biến động về dân số được thực hiện bởi cộng tác viên dân số và y tế thôn bản, bao gồm những thông tin về thành viên hộ gia đình trong 9 xóm thuộc địa bàn nghiên cứu. Số liệu điều tra dân số cung cấp thông tin về mối quan hệ của các thành viên trong hộ gia đình với chủ hộ, giới tính, ngày tháng năm sinh, nơi sinh, dân tộc, trình độ học vấn, tình trạng hôn nhân, tình trạng tàn phế, tình trạng định cư. Theo kết quả số liệu thống kê dân số của 637 hộ gia đình và 2.912 nhân khẩu tại các xóm trong mẫu nghiên cứu, có $54 \%$ dân số là người dân tộc thiểu số, $46 \%$ hộ gia đình có chủ hộ là người dân tộc thiểu số (chủ yếu là Dao, H'mong). 
Bảng 5: Thông tin số hộ gia đình và số dân ở 9 làng nghiên cứu

\begin{tabular}{|c|c|c|c|c|c|c|c|c|}
\hline \multirow[b]{2}{*}{ Làng nghiên cứu } & \multicolumn{3}{|c|}{ Số hộ gia đình } & \multirow{2}{*}{$\begin{array}{l}\text { Tî lệ hộ } \\
\text { dân tộc }\end{array}$} & \multicolumn{3}{|c|}{ Số người cư trú } & \multirow{2}{*}{$\begin{array}{c}\text { \% dân } \\
\text { tộc cư } \\
\text { trú }\end{array}$} \\
\hline & Tổng số & Kinh & Dân tộc & & T.số & Kinh & Dân tộc & \\
\hline Tổng số & 637 & 344 & 293 & 46.0 & 2912 & 1353 & 1559 & 53.5 \\
\hline Tổng số nhóm A & 265 & 119 & 146 & 55.1 & 1204 & 497 & 707 & 58.7 \\
\hline Làng $A 1$ & 71 & 44 & 27 & 38.0 & 322 & 178 & 144 & 44.7 \\
\hline Làng A2 & 45 & 25 & 20 & 44.4 & 225 & 108 & 117 & 52.0 \\
\hline Làng $\mathrm{A} 3$ & 48 & 47 & 1 & 2.1 & 203 & 196 & 7 & 3.4 \\
\hline Làng A4 & 49 & 3 & 46 & 93.9 & 207 & 15 & 192 & 92.8 \\
\hline Làng A5 & 52 & 0 & 52 & 100.0 & 247 & 0 & 247 & 100.0 \\
\hline Tổng số nhóm B & 372 & 225 & 147 & 39.5 & 1708 & 856 & 852 & 49.9 \\
\hline Làng B1 & 59 & 49 & 10 & 16.9 & 240 & 178 & 62 & 25.8 \\
\hline Làng B2 & 74 & 74 & 0 & 0.0 & 284 & 280 & 4 & 1.4 \\
\hline Làng B3 & 103 & 100 & 3 & 2.9 & 440 & 391 & 49 & 11.1 \\
\hline Làng B4 & 136 & 2 & 134 & 98.5 & 744 & 7 & 737 & 99.1 \\
\hline
\end{tabular}

Nguồn: Thống kê dân số 2005

Số liệu thống kê dân số được nhóm nghiên cứu xử lý, phân tích phụ thuộc vào số liệu dân số, chất lượng của số liệu thống kê dân số, trình độ học vấn của các cộng tác viên dân số và khả năng tiếp cận về địa lý của từng xóm. Sai số báo cáo thường liên quan đến tình trạng định cư của các thành viên trong gia đình vì tình trạng này luôn thay đổi, cần cập nhật thường xuyên. Có sự nhầm lẫn thành viên cố định, hợp pháp và không thực tế của hộ gia đình. Vì thời gian có hạn, nhóm nghiên cứu không thể tiến hành điều tra lại số liệu về dân số tại các xóm, chúng tôi đã cố gắng xử lý tốt nhất thông tin về hộ gia đình trong mẫu nghiên cứu và thấy khoảng $23 \%$ các hộ gia đình cần cập nhật thông tin, sửa chữa một số sai lệch nhỏ so với số liệu trong sổ thống kê dân số tại thời điểm điều tra.

\section{3. Điều tra hộ gia đình}

Mục đích đầu tiên của điều tra hộ gia đình là xem sự tăng trưởng kinh tế ở Việt Nam ảnh hưởng như thế nào đến đời sống của đồng bào người dân tộc Kinh và dân tộc thiểu số tại các gia đình ở miền núi, vùng sâu. Số liệu trong điều tra hộ gia đình cho phép đánh giá hoàn cảnh gia đình của thanh niên ở vùng sâu, vùng xa khi họ còn nhỏ và hiện tại. Trong điều tra, tổng số 150 hộ đã được chọn lọc ngẫu nhiên để thu thập các thông tin chi tiết về hộ gia đình. Trước hết, tất cả các số liệu thống kê hộ gia đình được phân chia theo các nhóm dân tộc của chủ hộ. Trong mỗi cụm dân cư nhóm nghiên cứu chọn ngẫu nhiên 38 hộ. Chúng tôi đã chọn 38 hộ dân tộc Dao tại cụm $\mathrm{A}$ và 38 hộ dân tộc H'mong tại cụm B. Như vậy có 26 \% hộ gia đình Dao, hoặc H'mong được chọn làm mẫu nghiên cứu. 
Bảng 6: Số hộ gia đình lựa chọn ngẫu nhiên để thu thập thông tin

\begin{tabular}{lrrr}
\hline \multirow{2}{*}{ Nhóm A } & \multicolumn{3}{c}{ Số hộ gia đình } \\
\cline { 2 - 4 } & Tổng & Kinh & Dao \\
\hline Tổng số làng nhóm A & 75 & 37 & 38 \\
Làng A1 & 18 & 14 & 4 \\
Làng A2 & 11 & 8 & 3 \\
Làng A3 & 15 & 15 & 0 \\
Làng A4 & 14 & 0 & 14 \\
Làng A5 & 17 & 0 & 17 \\
\hline
\end{tabular}

\begin{tabular}{lrrr}
\hline \multirow{2}{*}{ Nhóm B } & \multicolumn{3}{c}{ Số hộ gia đình } \\
\cline { 2 - 4 } & Tống & Kinh & H'mong \\
\hline Tổng số làng nhóm B & 75 & 37 & 38 \\
Làng B1 & 11 & 11 & 0 \\
Làng B2 & 11 & 11 & 0 \\
Làng B3 & 15 & 15 & 0 \\
Làng B4 & 38 & 0 & 38 \\
\hline
\end{tabular}

Ở mỗi hộ gia đình, nhóm nghiên cứu tiến hành phỏng vấn chủ hộ. Khi chủ hộ đi vắng, vợ của chủ hộ là người được phỏng vấn. Trong trường hợp cả chủ hộ và vợ đi vắng, một người trưởng thành là thành viên trong hộ có hiểu biết về các hoạt động của hộ sẽ được chọn để phỏng vấn thu thập thông tin chi tiết, họ được coi là người cung cấp thông tin về hộ gia đình. Trong thời gian nghiên cứu, điều tra viên được tập huấn về bộ câu hỏi thu thập thông tin và thực hiện việc cập nhật, sửa chữa các thông tin về hộ viên gia đình của số liệu thống kê. Đánh giá điều kiện sống của $1 / 4$ hộ gia đình trong mẫu nghiên cứu, bao gồm cả những chi tiết về điều kiện gia đình và những thay đổi gần đây về điện thắp sáng và sinh hoạt, cung cấp nước sạch. Ngoài ra, còn một bộ số liệu bao gồm cả những thông tin về sở hữu ruộng đất, tình trạng mùa màng.

Những thông tin về các hoạt động chung cũng được thu thập, mục đích để hiểu thực trạng kinh tế hộ gia đình và đóng góp của các thành viên trong hộ gia đình. Nhóm nghiên cứu còn thu thập số liệu về thu nhập, chi phí, các khoản vay nợ. Chúng tôi cũng thu thập những thông tin về mùa màng, công việc chăn nuôi, thu nhập chính, thu nhập hiện tại, thu nhập từ công việc kinh doanh như buôn bán, lao động chân tay. Những thông tin chi tiết về các thành viên trong hộ gia đình, kể cả những người đang sống và làm việc sau khi thoát ly khỏi công việc đồng ruộng cũng được thu thập. Những số liệu này có thể đánh giá các khoản thu nhập, chi tiêu, vay mượn trong gia đình.

Ngoài ra nhóm nghiên cứu cũng đã thu thập những thông tin về điều kiện địa lý xã hội; mức độ tham gia của hộ gia đình trong các chương trình cải thiện giao thông, xóa đói giảm nghèo; hiểu biết của hộ gia đình về các chương trình phát triển kinh tế, xã hội, giáo dục, y tế đang triển khai tại địa phương và những khó khăn thời thơ ấu cũng như những nguyên nhân dẫn đến những khó khăn đó.

\subsection{Phỏng vấn sâu}

Mục đích của phỏng vấn sâu là làm rõ những thay đổi nhanh chóng về xã hội đã tác động như thế nào đến sự thay đổi đối với thanh niên trưởng thành tại các khu vực vùng sâu vùng xa ở miền núi Việt Nam. Nhóm nghiên cứu đã tiến hành phỏng vấn sâu không có cấu trúc, ít mang tính định lượng so với số liệu thống kê điều tra hộ gia đình để đưa ra được bức tranh chi tiết về thời niên thiếu của các thanh niên. Tổng số 60 
thanh niên đã được chọn có chủ đích để tiến hành phỏng vấn sâu. Trước tiên chúng tôi phân chia tất cả đối tượng nghiên cứu từ 15-29 tuổi trong 150 hộ gia đình theo các xóm, dân tộc, tình trạng hôn nhân. Tất cả các thanh niên để phỏng vấn sâu được lựa chọn từ 60 hộ gia đình khác nhau. Cách lựa chọn đảm bảo các đối tượng được phỏng vấn tương đối cân bằng về giới (nam, nữ); dân tộc (Kinh, Dao và H'mong); người sống độc thân, chưa xây dựng gia đình và người đã xây dựng gia đình. Một số thanh niên $(n=7)$ của những dân tộc khác cũng được chọn có chủ đích để phỏng vấn.

Các thanh niên trong mẫu nghiên cứu được phỏng vấn sâu 2 lần, mỗi lần cách nhau ít nhất 3 tuần. Trong lần phỏng vấn thứ nhất họ được hỏi về thời niên thiếu, mối liên hệ, quan hệ với các thành viên khác trong gia đình và người xung quanh, vấn đề học tập, sự thay đổi từ việc đi học sang lao động giúp đỡ gia đình và những hiểu biết về ở ngoài thôn xóm của họ. Nhóm nghiên cứu cũng đánh giá quan niệm của thanh niên về lợi nhuận, khó khăn khi trải qua những sự kiện quan trọng như đạt được trình độ học vấn cao hơn, khi thoát ly, làm việc ở các địa phương khác trong nước hoặc nước ngoài, khi xây dựng gia đình quá sớm. Trước khi phỏng vấn, người phỏng vấn đã được tập huấn và cung cấp một bản hướng dẫn phỏng vấn.

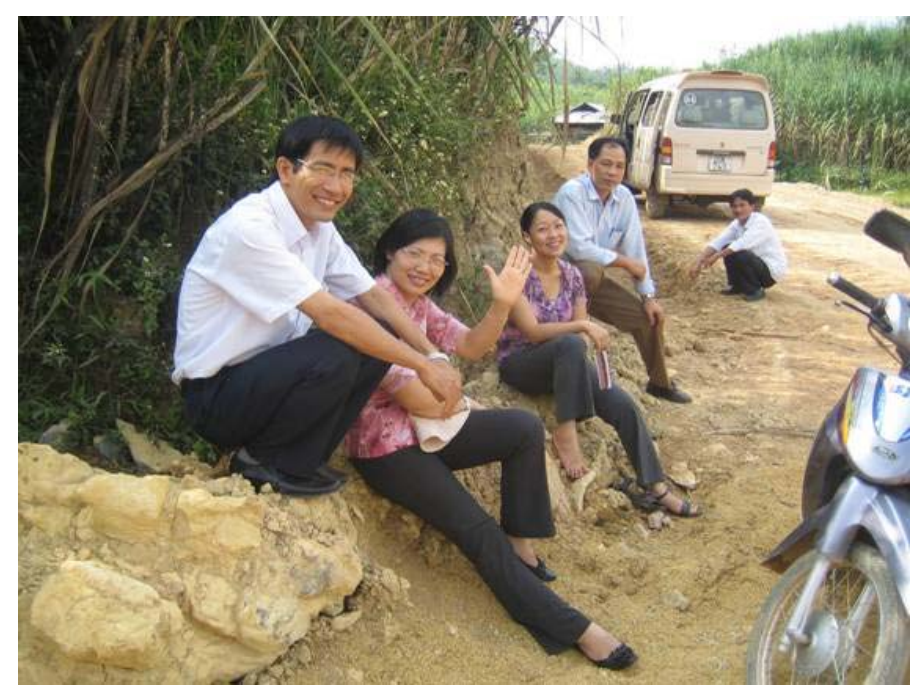

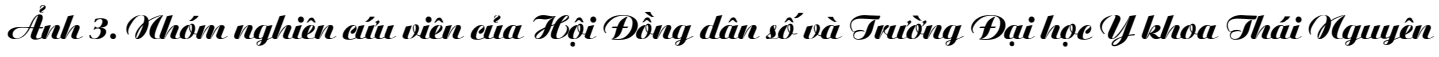

Khoảng từ 4 đến 6 tuần sau lần thăm hộ gia đình đầu tiên, nhóm nghiên cứu tiến hành thăm hộ gia đình lần thứ hai, mục đích của lần này là bổ sung các thông tin và đặc biệt các thông tin thuộc các chủ đề mang tính nhạy cảm và làm rõ hơn các thông tin của lần thăm hộ gia đình đầu tiên. Nhóm nghiên cứu đã cố gắng để một người phỏng vấn cùng một đối tượng ở cả hai lần. Những thông tin, hiểu biết và hành vi mang tính nhạy cảm như quan hệ tình dục, sức khỏe sinh sản, đặc biệt là kế hoạch hóa gia đình, nạo phá 
thai đã được điều tra. Những số liệu về cách tổ chức đám cưới, chi phí cho đám cưới theo phong tục tập quán ở từng địa phương cũng được thu thập đối với những người đã xây dựng gia đình. Thanh niên cũng được hỏi để đánh giá sự hiểu biết về hoạt động văn hóa xã hội, tập quán đặc biệt trong nhóm dân tộc của họ, kế hoạch cho tương lai, mẫu hình lý tưởng mà họ muốn học tập và những điều quan tâm khác. Trong lần thăm hỏi thứ hai, các nghiên cứu viên phỏng vấn không có cấu trúc, thận trọng trong các câu hỏi thuộc các chủ đề mang tính nhạy cảm như hành vi tình dục.

Bên cạnh việc tìm hiểu cuộc sống của 60 thanh niên nam và nữ, nhóm nghiên cứu cũng phỏng vấn cha mẹ của họ. Trong trường hợp người được phỏng vấn là nam, chúng tôi đã phỏng vấn cha hoặc ông nội và ngược lại đối với người được phỏng vấn là nữ. Trong một vài trường hợp, nếu không gặp được cha mẹ, ông bà, nghiên cứu viên sẽ phỏng vấn những người họ hàng gần gũi thuộc thế hệ cha mẹ của họ. Mục tiêu là tìm hiểu quá khứ cuộc sống của cha mẹ có gì giống và khác so với con cái của họ và ảnh hưởng của cha mẹ đến cuộc sống của thanh niên. Những chi tiết về lịch sử cuộc sống gia đình, đặc biệt những thay đổi của thanh niên cũng được thu thập.

Nhóm nghiên cứu đã phỏng vấn thanh niên về thế hệ cha mẹ của họ, về sự chuẩn bị học hành kinh nghiệm làm việc, quan hệ nam nữ, quan hệ với các thành viên khác giữa các nhóm dân tộc khác nhau, cách tổ chức đám cưới, hành vi tình dục và sức khỏe sinh sản.

Lần phỏng vấn sâu đầu tiên được tiến hành khi vụ mùa vừa kết thúc. Hầu hết thanh niên đều ở nhà vì vâyy tỷ lệ các đối tượng được phỏng vấn đạt gần như tối đa. Cuộc phỏng vấn thứ hai tiến hành sau khi vụ thu hoạch đã kết thúc. Có lẽ do nhu cầu ngày càng cao trong cuộc sống, lại sã̃n có xe máy và nhu cầu thu nhập thêm, một số người dân trong xóm đã đi tới các địa phương khác để tìm kiếm việc làm tạm thời hoặc thăm hỏi bà con. Điều này cũng ảnh hưởng đến tỷ lệ đáp ứng số lượng mẫu nghiên cứu, nhóm nghiên cứu đã không thể thực hiện phỏng vấn tiếp 3 thanh niên và 1 người là cha, mẹ tại cụm dân cư $\mathrm{A} ; 4$ thanh niên và 3 người là cha mẹ trong cụm dân cư $\mathrm{B}$.

Sau 4 tháng tích cực thu thập số liệu, nhóm nghiên cứu đã tiến hành 190 cuộc phỏng vấn sâu ở hai xã Phương Giao và Tràng Xá. Chúng tôi đã xử lý số liệu thống kê dân số của các xóm thuộc địa bàn nghiên cứu và tiến hành cuộc điều tra chọn mẫu hộ gia đình với 150 hộ gia đình. 60 hộ được chọn để đến thăm lần thứ hai và tiến hành phỏng vấn sâu để bổ sung và làm rõ các thông tin cần thiết. Điểm mạnh của nghiên cứu tăng cường là cho phép điều tra rộng hơn hoàn cảnh lịch sử của cá nhân và gia đình. Nhóm nghiên cứu đã cố gắng tận dụng điểm mạnh này để đánh giá tính ứng dụng thực tế đến đời sống của thanh niên và các tác động khác nhau tới nhóm dân tộc Kinh và dân tộc thiểu số. Số liệu phong phú về hộ gia đình và cá nhân giúp cho nhóm nghiên cứu phân tích mối liên hệ của cộng đồng với những số liệu của chương trình quốc gia điều tra về đói nghèo, dân số và sức khỏe. 


\section{Chương 3 \\ TìNH HÌNH KINH TẾ - XÃ HộI Ở VÙNG NGHIÊN CỨU}

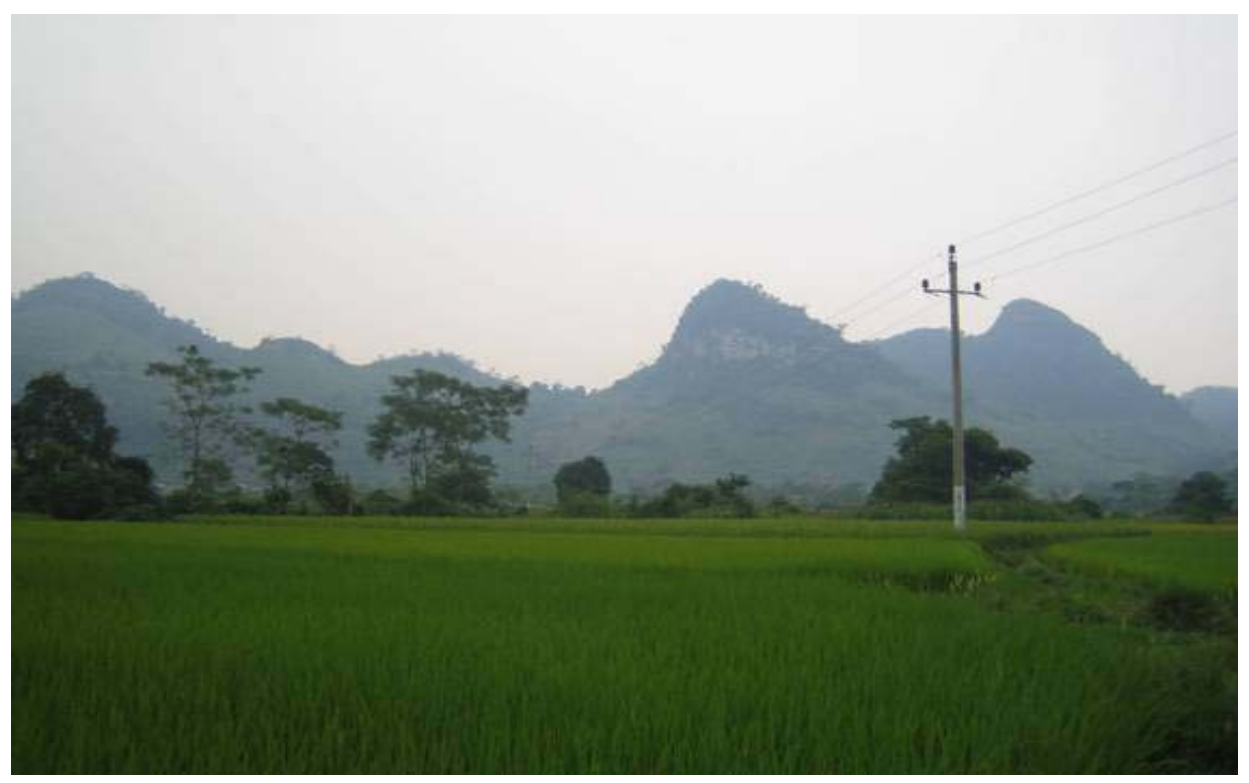

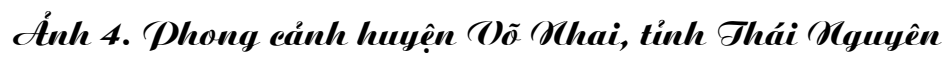

địa điềm nghiên cuńu tại tỉnk miền múi vìng sâu ở Oiệt Mam.

Nghiên cứu được tiến hành tại huyện Võ Nhai tỉnh Thái Nguyên, lựa chọn hai vùng nghiên cứu đại diện cho vùng sâu, miền núi Việt Nam, nơi có nhiều dân tộc sinh sống, họ đang trải qua sự thay đổi một cách nhanh chóng và là đối tượng của chương trình xoá đói giảm nghèo trong 5 năm qua. Chương này mô tả tình hình kinh tế - xã hội của vùng này và nghiên cứu dân số qua đánh giá nhanh cộng đồng, nghiên cứu dân số và điều tra hộ gia đình. Chương này gồm 5 phần như sau:

Đặc điểm tự nhiên và tiếp cận.

Đặc điểm về nhân khẩu học.

Cơ sở hạ tầng xã hội.

Kinh tế và thu nhập - các hoạt động tạo ra thu nhập.

Sự tham gia vào chương trình xoá đói giảm nghèo. 


\section{1. Đặc điểm tự nhiên và tiếp cận}

Võ Nhai là huyện nghèo nhất, xa nhất và kém phát triển nhất trong số 9 huyện của tỉnh Thái Nguyên. Huyện cách Hà Nội khoảng 130km đi theo đường quốc lộ 3-1B. Đường quốc lộ xuyên tỉnh (quốc lộ $1 \mathrm{~B}$ ) nối thành phố Thái Nguyên với huyện Bắc Sơn của tỉnh Lạng Sơn qua thị trấn Đình Cả huyện Võ Nhai. Từ Hà Nội đi Đình Cả theo đường ô tô mất khoảng 3 giờ.

Nghiên cứu được tiến hành tại xã Phương Giao và Tràng Xá ở phía nam của huyện Võ Nhai. Hai xã này cách nhau khoảng $12 \mathrm{~km}$. 5 xóm của xã Phương Giao, gọi là nhóm A cách thị trấn khoảng 20-30km. Nhóm $B$ gồm 4 xã của huyện Tràng Xá cách thị trấn Đình Cả khoảng 15 đến $20 \mathrm{~km}$. Từ năm 2000, đã có đường nhựa từ thị trấn Đình Cả đến trung tâm của các xã. Tuy nhiên, đường đất từ trung tâm xã đến địa điểm nghiên cứu khó đi hơn. Vào mùa khô mất khoảng 1,5 giờ để đi từ thị trấn Đình Cả đến nhóm $\mathrm{A}$ và 45 phút đến nhóm $\mathrm{B}$. Hầu hết người dân trong làng đi bằng xe máy; đi xe đạp hoặc đi bộ thường mất nhiều thời gian hơn. Vào mùa mưa, việc đi lại đến địa điểm nghiên cứu gặp nhiều khó khăn hơn, không thể đi bộ được đến một số hộ gia đình do họ ở trên núi cao, đường trơn, dốc cao và không có cầu bắc qua suối.

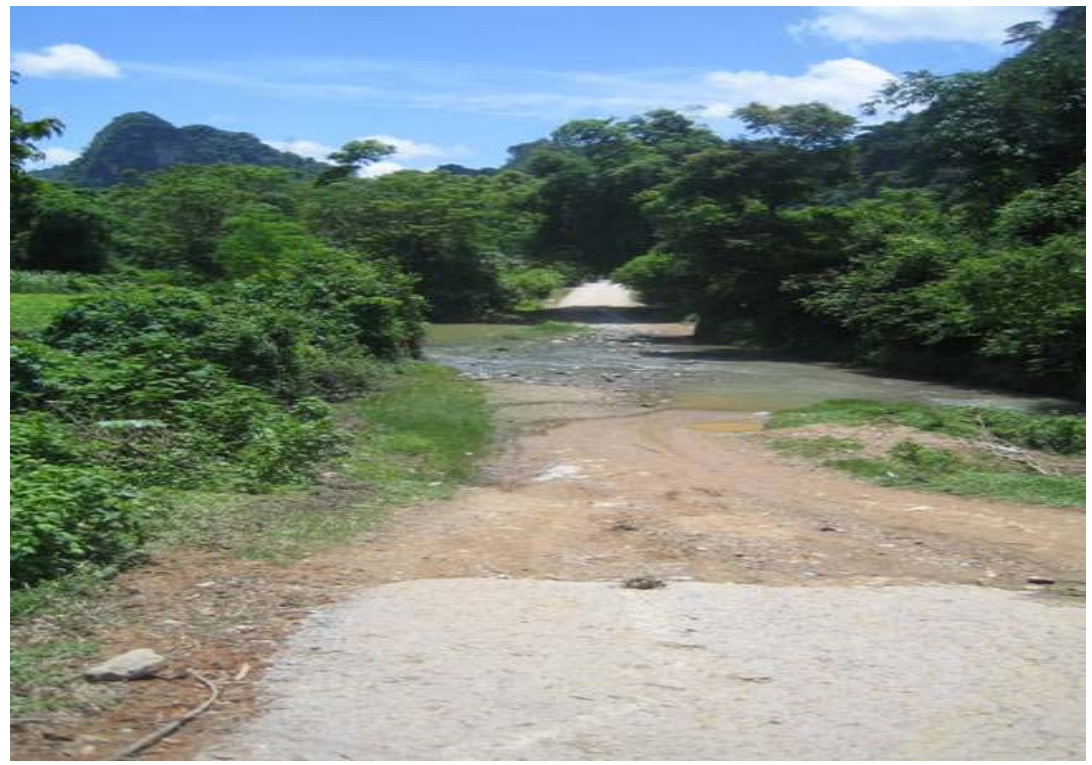

Cink 5. Con đường đi tù̀ hủy ban nhân dân xẽ

đến các xóm nghiên cú́u của xẽ Phương Ciao.

Nhìn chung đường xá trong vùng của người Dao và H'mong trong vùng nghiên cứu đi lại khó khăn hơn đường xá ở vùng người Kinh. Ví dụ ở nhóm $\mathrm{A}$, đường được làm từ năm 2002 nối 3 làng của người Kinh với trung tâm xã Phương Giao. Đến năm 2004 làng của người Dao mới có thể đi được bằng xe máy (làng A4). Tình trạng giao 
thông khác nhau của các dân tộc có thể được giải thích một phần do các bản dân tộc thiểu số sống ở trên cao và ở xa hơn so với người Kinh. Một nguyên nhân khác có thể được giải thích là do thiếu chính sách xã hội hỗ trợ cho người dân tộc thiểu số, họ chưa được tham gia vào việc ra quyết định ở cấp xã, đặc biệt trong việc phân bổ nguồn lực và phát triển cơ sở hạ tầng.

Lãnh đạo địa phương gồm cả người Kinh và người dân tộc thiểu số cho rằng làng của họ có khả năng làm đường liên xã trong nhiều năm qua. Điển hình là những ý kiến sau:

... Ngày xưa chúng tôi đi bộ đến chợ ở Đình Cả. Nó mất hai ngày. Ngày đầu tiên chúng tôi đi từ làng đến chợ, chúng tôi chỉ đến được chợ khi trời đã tối. Chúng tôi phải ngủ đêm ở đó. Đến sáng ngày hôm sau chúng tôi mới có thể mua bán. Chúng tôi mua muối, mỡ, măm... Đến khoảng 10 giờ sáng chúng tôi đi bộ về nhà. Khi đến được nhà thì trời đã tối...

Một phụ nữ 75 tuổi ở làng A3 nhớ về cuộc sống của bà hồi trẻ ở Phương Giao. Bà và chồng bà đã lấy nhau ở tỉnh Hưng Yên, bên bờ sông Hồng và họ đã đến vùng núi này vào giữa những năm 1960.

... Trước khi con đường được xây dụing, nhũng người dân phải đi bộ đến chợ Đình Cả để bán các sản phẩm ho làm được. Vì chợ rất xa nên ho chỉ mang được ít các sản phẩm trong một lần đi chợ. Họ phải đi tù 4 giờ sáng và trở về nhà lúc 8 giờ tối. Đường mới xây dựng làm cho việc đi lại dễ dàng hơn. Bây giờ có nhiều gia đình đã có xe máy...

Chủ tịch, Kinh, nam, Uỷ ban nhân dân xã Phương Giao.

Theo điều tra hộ gia đình, $41 \%$ các hộ gia đình ở nhóm $\mathrm{A}$ có xe máy và nhóm $\mathrm{B}$ là $57 \%$. Vài người dân đã bán trâu để mua xe. Tỷ lệ hộ gia đình đã có và sẽ có xe máy còn tăng lên trong những năm tới. Nhu cầu phát triển đường xá, đặc biệt là đường liên xóm khá cao. Nhiều hộ gia đình khi chúng tôi phỏng vấn mong muốn có thêm tiền để mở rộng và nâng cấp đường. Duy tu bảo dưỡng đường là vấn đề cấp bách nhưng chưa được coi trọng vì vậy chúng tôi không thảo luận sâu hơn, trừ một lãnh đạo của làng người Kinh ở nhóm $\mathrm{B}$ có ý kiến:

Trong mùa khô, xe tải có thể đến làng chúng tôi để chở hàng hoá. Nhưng khi mưa to, đường trở nên trơn và lây lội nên không thể đi lại được bằng xe tải hay xe máy. Đường này mới làm vài năm trước đây nhưng mặt đường đã bị phá huỷ vì quá tải.

So với nhóm $\mathrm{A}$, nhóm $\mathrm{B}$ gần thị trấn huyện hơn, đường giao thông tốt hơn. Vì lý do này nhóm $\mathrm{B}$ có sự tiện lợi hơn về mặt xã hội. Các đặc điểm tự nhiên của nhóm $\mathrm{B}$ nhìn chung phát triển hơn nhóm $\mathrm{A}$. Theo bảng phân tích số liệu điều tra hộ gia đình bảng 8 gần như toàn bộ các hộ gia đình nhóm $\mathrm{B}(99 \%)$ có điện nhưng ở nhóm $\mathrm{A}$ chỉ là $88 \%$. Các hộ gia đình người Kinh ở nhóm $\mathrm{B}$ đều có điện, chênh lệch khá lớn với nhóm A, chỉ có $92 \%$ hộ gia đình người Kinh có điện, trong khi đó hộ người Dao là $84 \%$. 
Trong nhóm A, lần đầu tiên điện được kéo vào khoảng năm 2003-2004 trong những làng người Kinh. Sau đó hai năm điện mới được kéo đến những hộ người Dao. Vào thời gian điều tra năm 2006, chỉ có một nửa số hộ người Dao ở làng vùng sâu (làng A5) có điện. Tỷ lệ có điện tương đối thấp vì mỗi hộ gia đình phải chịu chi phí lắp đặt khá cao, khoảng 675.000 VND. Giá điện là 700 đồng/kilowat và trung bình mỗi hộ gia đình phải trả khoảng 50.000 đồng tiền điện hàng tháng.

Bảng 8. Đặc điểm và khả năng tiếp cận với điều kiện sống theo dân tộc của chủ hộ

\begin{tabular}{|c|c|c|c|c|c|c|}
\hline \multirow[b]{2}{*}{ Đặc điểm hộ gia đình } & \multicolumn{3}{|c|}{ Nhóm A } & \multicolumn{3}{|c|}{ Nhóm B } \\
\hline & $\begin{array}{c}\text { Tất cả các } \\
\text { làng } \\
(\mathrm{N}=75)\end{array}$ & $\begin{array}{l}\text { Làng người } \\
\text { Kinh } \\
(\mathrm{N}=37)\end{array}$ & $\begin{array}{l}\text { Làng người } \\
\text { Dao } \\
(\mathrm{N}=38)\end{array}$ & $\begin{array}{c}\text { Tất cả } \\
\text { các } \\
\text { làng } \\
(\mathrm{N}=75)\end{array}$ & $\begin{array}{l}\text { Làng } \\
\text { người } \\
\text { Kinh } \\
(\mathrm{N}=37)\end{array}$ & $\begin{array}{c}\text { Làng } \\
\text { người } \\
\text { H'mong } \\
(\mathrm{N}=38)\end{array}$ \\
\hline \multicolumn{7}{|l|}{ Cơ sở hạ tầng cơ bản } \\
\hline \% hộ gia đình có điện & 88 & 92 & 84 & 99 & 97 & 100 \\
\hline $\begin{array}{l}\text { \% hộ gia đình có nước lọc } \\
\text { hoặc nước giếng }\end{array}$ & 52 & 70 & 34 & 65 & 78 & 53 \\
\hline \% hộ gia đình có hố xí & 27 & 41 & 13 & 56 & 78 & 34 \\
\hline \multicolumn{7}{|c|}{ Khả năng tiếp cận của hộ gia đình (khoảng cách tính bằng km) } \\
\hline Chợ & 11.1 & 11.8 & 10.4 & 4.8 & 3.6 & 5.9 \\
\hline Bưu điện & 6.4 & 5.4 & 7.3 & 8.9 & 6.8 & 10.8 \\
\hline Trạm y tế xã & 6.4 & 5.4 & 7.2 & 9.2 & 6.9 & 11.1 \\
\hline
\end{tabular}

Nguồn: Điều tra hộ gia đình năm 2006

Đối với cơ sở hạ tầng cơ bản, điều tra hộ gia đình cho thấy nhóm $\mathrm{B}$ (chủ yếu là dân tộc Kinh) tiếp cận với nguồn nước sạch và vệ sinh môi trường tốt hơn nhóm $\mathrm{A}$. Gần $80 \%$ hộ người Kinh nhóm $\mathrm{B}$ dùng nước lọc hoặc nước giếng so với $70 \%$ người Kinh ở nhóm $\mathrm{A}, 53 \%$ người $\mathrm{H}$ 'mong và $34 \%$ người Dao. Cơ sở hạ tầng về vệ sinh như hố xí ở đây rất thấp. Chỉ có $13 \%$ hộ người Dao được nghiên cứu trả lời có hố xí. Tỷ lệ hộ gia đình có hố xí có cao hơn nhưng không nhiều ở những nhóm dân tộc khác: 34\% hộ gia đình dân tộc H'mong và $41 \%$ hộ gia đình dân tộc Kinh ở nhóm A. Tỷ lệ hộ gia đình người Kinh nhóm $\mathrm{B}$ có hố xí là $78 \%$.

Một trong những đặc điểm tự nhiên quan trọng làm cho nhóm $\mathrm{B}$ phát triển hơn nhóm A là chợ Đông Bo - chợ phiên họp 5 ngày 1 lần. Khoảng cách trung bình từ hộ gia đình nhóm $\mathrm{B}$ đến chợ Đông Bo là $5 \mathrm{~km}$. Trong khi đó khoảng cách trung bình từ các hộ gia đình ở nhóm $\mathrm{A}$ đến chợ gần nhất xa gấp hai lần (bảng 8). Chợ Đông Bo nhỏ được phân chia để kinh doanh hai nhóm hàng hóa khác nhau. Nhóm hàng hóa thứ nhất là hàng tươi sống và thực phẩm chẳng hạn như rau, đậu và thịt lợn, người bán hàng chủ yếu là những nông dân đến từ làng nghiên cứu hoặc những làng lân cận. 
Nhóm hàng hóa thứ hai là quần áo, giày dép và các đồ dùng gia đình khác, hầu hết những người bán hàng nhóm thứ hai đến từ thị trấn hoặc nơi khác. Một vài gia đình bao gồm cả những nhà giàu nhất trong khu vực nghiên cứu đều có cửa hàng nhỏ ở chợ. Xã Phương Giao-nhóm A-không có chợ riêng. Có vài cửa hàng nhỏ bán đồ tạp hoá ở địa bàn nhóm $\mathrm{A}$ bán thịt lợn, thực phẩm khô chẳng hạn như mì ăn liền. Tháng 12 năm 2006, một phụ nữ người Kinh đã lập ra cửa hàng bán rau hoa quả đầu tiên ở làng A2 (làng người Kinh).

Ngoài chợ, cả hai xã đều có trạm y tế và bưu điện. Những cơ sở này được đặt ở trung tâm của mỗi xã. Trạm y tế xã Phương Giao được thành lập năm 1999, bưu điện xây dựng năm 2002. Ở Tràng Xá những cơ sở này có sớm hơn và cơ sở vật chất cũng tốt hơn. Người dân ở nhóm $\mathrm{A}$ có thể tìm kiếm dịch vụ y tế hiện đại ở trạm y tế xã, các dịch vụ y tế tư nhân ngoài giờ (do bác sỹ của trạm cung cấp). Tương tự như vậy, bưu điện là nơi gần nhất người ta có thể gọi điện thoại. Những người dân ở nhóm $\mathrm{B}$ có nhiều lựa chọn hơn trong việc tiếp cận với dịch vụ y tế và phương tiện để liên lạc với thế giới bên ngoài ít nhất có quầy dược được đặt ở trung tâm của xã. Nhóm $\mathrm{B}$ tiếp cận với công nghệ bưu chính viễn thông cũng hiện đại hơn. Vài hộ gia đình (người Kinh) nhóm $\mathrm{B}$ có điện thoại riêng và giúp cho những người dân trong làng được dùng điện thoại và trả một số tiền nhỏ vì vậy người dân không cần phải đến tận trung tâm của xã để sử dụng điện thoại tại bưu điện. Một số gia đình thành đạt ở nhóm $\mathrm{B}$ đã sử dụng điện thoại di động để liên lạc với những người làm nghề buôn bán ở thị trấn Đình Cả và các tỉnh khác như Bắc Ninh, Bắc Giang phục vụ việc kinh doanh sản phẩm nông nghiệp.

\section{2. Đặc điểm nhân khẩu học}

Bảng 9. Đặc điểm điều kiện địa lý theo dân tộc và nhóm tuổi, 2005

\begin{tabular}{|c|c|c|c|c|c|}
\hline \multirow[b]{2}{*}{ Đặc điểm địa lý } & \multicolumn{3}{|c|}{ Kinh* } & \multirow[b]{2}{*}{ Dao } & \multirow[b]{2}{*}{ H'mong } \\
\hline & $\begin{array}{c}\text { Tổng số } \\
\text { Kinh }\end{array}$ & Nhóm A & Nhóm B & & \\
\hline Dân số & 1527 & 563 & 964 & 646 & 736 \\
\hline Tổng số nữ & 761 & 264 & 497 & 329 & 367 \\
\hline Tổng số nam & 766 & 299 & 467 & 317 & 369 \\
\hline Quy mô trung bình của hộ gia đình & 4.2 & 4.4 & 4.1 & 4.7 & 5.5 \\
\hline Tuổi trung bình & 27.7 & 27.1 & 28.1 & 24.1 & 22.2 \\
\hline \% trẻ dưới 5 tuổi & 5.4 & 5.5 & 5.4 & 7.7 & 11.3 \\
\hline \% dân số từ 15 đến 49 tuổi & 33.9 & 33.0 & 34.5 & 34.8 & 34.1 \\
\hline$\%$ dân số từ 15 đến 29 chưa kết hôn & 30.6 & 34.9 & 28.2 & 44.0 & 46.2 \\
\hline
\end{tabular}

Nguồn: Điều tra dân số năm 2005

* Tổng số Kinh bao gồm cả Nùng, Tày, Mường và Sán Dìu (6\% tổng số dân) sống ở vùng nghiên cứu 
Phần này chúng tôi dựa trên điều tra dân số các làng năm 2005. Như đã trình bày ở chương trước (bảng 5), số dân nhóm $\mathrm{A}(\mathrm{N}=1.204)$ nhỏ hơn số dân nhóm $\mathrm{B}(\mathrm{N}=1.708)$. Cả hai nhóm đều gồm nhiều dân tộc: $41 \%$ dân nhóm $\mathrm{A}$ là người Kinh, $53 \%$ người Dao và $6 \%$ là các dân tộc khác như Tày, Nùng, Mường, Sán Dìu. Đối với nhóm $\mathrm{B}$, người Kinh chiếm một nửa dân số, người $\mathrm{H}$ 'mong là $43 \%$ và $7 \%$ là dân tộc khác. Nhóm $\mathrm{A}$ dân sống thưa thớt hơn nhóm B. Theo điều tra dân số năm 1999, mật độ dân số ở xã Phương Giao (nhóm $\mathrm{A}$ ) là 58 người $/ \mathrm{km}^{2}$ so với Tràng Xá là 147 người/ $\mathrm{km}^{2}$ và mật độ chung của huyện Võ Nhai là 300 người $/ \mathrm{km}^{2}$.

Bảng 9 mô tả đặc điểm cơ bản về nhân khẩu học ở vùng nghiên cứu theo 3 nhóm: Kinh, Dao và H'mong. Chúng tôi cũng tìm hiểu sự khác nhau của người Kinh giữa nhóm $\mathrm{A}$ và $\mathrm{B}$. Những nhóm dân tộc khác xếp cùng với nhóm Kinh vì tỷ lệ các nhóm này rất thấp và họ có phong tục, tập quán gần với người Kinh hơn là người Dao và H'mong. Theo bảng 9, tổng số người Kinh trong vùng nghiên cứu năm 2005 là 1.527 người. $37 \%$ họ nằm trong nhóm $\mathrm{A}(\mathrm{N}=563)$ và số còn lại nằm trong nhóm $\mathrm{B}(\mathrm{N}=964)$. Số người dân tộc thiểu số ít hơn người Kinh. Có 646 và 736 người Dao và H'mong trong vùng nghiên cứu. Tính trung bình, quy mô gia đình ở vùng nghiên cứu của người Kinh nhỏ hơn quy mô gia đình người các dân tộc khác, điều này phản ánh tỷ lệ sinh của các gia đình người Kinh thấp hơn. Tỷ suất sinh của người Việt Nam đã giảm xuống $(2,11$ vào năm 2005). Tuy nhiên tỷ suất này rất khác nhau giữa các nhóm từ 1,87 ở người Kinh đến 3,2 ở người Dao và 7,06 ở người H'mong (Cục thống kê Việt Nam, 2001). Thống kê dân số ở xã cho thấy quy mô trung bình của hộ gia đình người Kinh nhóm $\mathrm{A}$ là 4,4 và nhóm $\mathrm{B}$ là 4,1. Hộ người Dao có quy mô trung bình là 4,7 người/hộ. Trong khi đó quy mô của hộ người H'mong là lớn nhất: 5,5 người/hộ.

Như là kết quả của tỷ suất sinh cao, cấu trúc dân số của người H'Mong trẻ hơn so với dân tộc khác ở vùng nghiên cứu. Tuổi trung bình của người H'mong là 22,2 tuổi, so với người Dao là 24,1 tuổi và người Kinh là 27,7 tuổi. Hơn nữa, trên $10 \%$ số người H'mong dưới 5 tuổi. Tỷ lệ trẻ dưới 5 tuổi của người Dao và người Kinh về cơ bản là thấp hơn: 7,7 và $5,4 \%$. Cấu trúc dân số theo tuổi cho thấy số người sống phụ thuộc của người H'mong cao hơn so với người Dao và Kinh, cứ 100 người ở độ tuổi lao động (từ 15 đến 64 tuổi), có 74 người trong nhóm phụ thuộc (dưới 15 tuổi hoặc trên 64 tuổi). Tỷ lệ sống phụ thuộc ở người Dao là $56 \%$ và ở người Kinh là $41 \%$.

Thống kê dân số cho thấy thanh niên và trung niên từ 15-49 tuổi chiếm khoảng $33 \%$ tổng số dân. Con số này giống nhau ở cả ba nhóm dân tộc và người Kinh ở cả nhóm $\mathrm{A}$ và nhóm $\mathrm{B}$. Một đặc điểm khác biệt nhất của thanh niên là thanh niên dân tộc lập gia đình sớm hơn người Kinh. Ví dụ: $44 \%$ ở người Dao và $46 \%$ người H'mong cưới ở độ tuổi 15-49. Trong khi tỷ lệ này ở người Kinh trong độ tuổi đó là $31 \%$. Tỷ lệ của người Kinh cưới trong độ tuổi này ở nhóm A (35\%) cao hơn ở nhóm B (28\%). 


\section{Cơ sở hạ tầng}

Những con đường dài nối liền các làng xóm được xây dựng ở những vùng thấp. Một số hộ gia đình, đặc biệt với người Dao nhóm $\mathrm{A}$ và người H'mong nhóm $\mathrm{B}$ sống ở vùng núi cao chỉ có những con đường nhỏ, trên triền dốc nối với con đường chung của xóm. Nhìn chung các hộ gia đình có xu hướng sống ở vùng trung tâm của xóm. Tuy nhiên việc phát triển dân số nhanh chóng (nguyên thuỷ là sự tăng dân số tự nhiên) và kết quả của tăng nhu cầu đất canh tác đã đẩy một số hộ phải đến vùng sâu hơn. Nhiều hộ gia đình sở hữu cả ruộng trồng lúa và đất đồi để trồng ngô hoặc trồng mía. Thậm chí các hộ gia đình ở trung tâm cũng phải canh tác ở những khu đất xa nhà. Hầu hết trong số họ phải di chuyển (thường là đi bộ) ít nhất vài cây số để đến nơi canh tác. Số ít hộ gia đình làm chỗ ở tạm tại nơi canh tác của họ.

Có hai loại nhà phổ biến ở địa điểm nghiên cứu. Loại thứ nhất là nhà sàn. Trái ngược với giả thuyết ban đầu của nhóm nghiên cứu, người Kinh sống trên nhà sàn nhiều hơn người dân tộc. Bức vách của nhà sàn thường làm bằng những tấm ván dài và mỏng, mái nhà lợp bằng ngói và sàn nhà là những tấm ván dày. Nhà luôn có một phòng rộng và chia làm nhiều khu khác nhau với những chức năng như ngủ, ăn uống hay tiếp khách. Bếp được tách biệt ra một khu riêng. Trong những tháng trời lạnh, bếp là nơi nghỉ ngơi và ngồi chơi vì đây là nơi ấm nhất của ngôi nhà. Phần dưới của nhà sàn được dùng như là kho để chứa đựng. Nhà sàn ở nhóm $\mathrm{A}$ phổ biến hơn ở nhóm $\mathrm{B}$. Loại phổ biến thứ hai là nhà đất. Rất nhiều loại nguyên liệu khác nhau được sử dụng để làm vách, nền và mái nhà phụ thuộc vào tình trạng kinh tế của từng hộ gia đình. Những người dân có điều kiện kinh tế khá giả thích nhà vách gỗ và nền xi măng còn những hộ nghèo luôn ở nhà đất với vách làm bằng tre và nền đất. Nhà đất cũng bố trí mặt bằng tương tự như nhà sàn. Nhà gạch phổ biến ở những vùng thấp cũng đã trở nên phổ biến ở đây, đặc biệt nhóm B nơi có thu nhập cao hơn nhóm A. Có ít nhất 3-4 hộ gia đình có nhà xây hai tầng. Những hiểu biết thu được trong quá trình thu thập thông tin đã giúp nhóm nghiên cứu giải thích về sự khác nhau trong việc sử dụng các loại nhà ở khác nhau giữa các nhóm dân tộc và theo thời gian. Khi mới đến khai hoang, người Kinh đã đến trước và để tránh thú rừng họ đã làm nhà sàn để ở, những ngôi nhà đó được làm rất chắc chắn nên vẫn còn tồn tại được đến ngày nay. Sau đó, thú rừng ít đi, việc phòng thú dữ không còn là nhu cầu, hơn nữa nguyên vật liệu làm nhà đất, việc vận chuyển nguyên vật liệu cũng như kỹ thuật làm nhà đã trở nên phổ biến, thuận lợi hơn nên càng về sau việc làm nhà đất hay xây nhà tầng càng được phổ cập. Do kỹ thuật, vật liệu, phương tiện sẵn có và đơn giản nên người dân tộc thiểu số dễ dàng bắt chước người Kinh làm nhà đất hơn.

Trong nghiên cứu này không có nhiều thông tin về lịch sử của các nhóm dân tộc. Người Dao di cư từ tỉnh Lạng Sơn và đã sinh sống ở huyện Võ Nhai nhiều thế hệ. Tương tự như vậy với vài người Kinh, đặc biệt là người Kinh sống ở làng $\mathrm{A} 1$ và $\mathrm{A}$ 2. Một người phụ nữ Kinh ở lứa tuổi 80 đã nói gia đình bà đã sống ở Phương Giao ít nhất 
từ đời cụ của bà. Trong khi hầu hết người Kinh, đặc biệt là những người dưới 45 tuổi sinh ra ở huyện Võ Nhai, một số người ở độ tuổi trung niên và những người già sống ở làng $\mathrm{A} 3$ trong nhóm $\mathrm{A}$ và những người ở lứa tuổi này trong nhóm $\mathrm{B}$ là những người di cư. Họ đến đây vào những năm 1960 từ Hưng Yên. Vào những năm 1960 và 1970 chính phủ có chính sách khuyến khích người dân từ vùng đồng bằng sông Hồng đến khu vực biên giới và những vùng kinh tế mới (9). Hầu hết người H'mong trong vùng nghiên cứu là những người di cư đến Võ Nhai. Ngoại trừ trẻ em và một số thanh niên, những người già sinh ra ở Cao Bằng gần biên giới Việt Nam và Trung Quốc sau đến cư trú tại đây từ chiến tranh biên giới giữa Việt Nam và Trung Quốc năm 1979 và để thoát khỏi cảnh nghèo khổ ở nơi ở cũ. Khi dòng người di cư từ Cao Bằng dần dần giảm xuống vào những năm 1980 thì có vài gia đình người H'mong đã chuyển đến đây vào những năm 2003. Theo điều tra dân số của các làng năm $2005,92 \%$ nam và $88 \%$ nữ người Kinh sinh ra tại đây. Trong khi đó, $87 \%$ người Dao và $64 \%$ người H'mong là dân bản xứ ở vùng đất này.

\section{Khung 3.1: Người dân tộc có còn mặc trang phục truyền thống nữa không?}

Người ngoài đến làng rất khó phân biệt các dân tộc khác nhau ở Phương Giao và Tràng Xá với người Kinh vì họ mặc những bộ quần áo hiện đại tương tụ nhau. Tuy nhiên những người dân tộc thì nói rờng không đến nỗi khó như vộy.

"Mặc như thế nào không thành vấn đề. Tôi không có khó khăn gì để nhận ra người cùng dân tộc với tôi. Chỉ cần liếc mắt tôi có thể biết người đó có phải là H'mong hay không. Những người H'mong trong bản chúng tôi luôn biết nhau." Một người H'mong trong bán người H'mong ở nhóm B nói một cách tụ tin về sụ thân thiết trong cộng đồng của họ.

Ngày nay chỉ có ít người H'mong và Dao ở vùng nghiên cứu mặc trang phục truyền thống hàng ngày. Hầu hết đều là những phụ nũ đã kết hôn. Những người phụ nữ trẻ và hầu hết đàn ông đều mặc quần áo người Kinh-quần hai ống và áo sơ mi.

"Mặc quần áo truyền thống đỉ làm đồng không tiện. Chúng dễ bị bẩn" Đây là lý do của Ly, người Dao 23 tuổi ở làng A5 nói về việc tại sao người Dao không còn mặc quần áo truyền thống.

Ly. cưới chồng khi cô 17 tuổi, sau khi cưới được văi năm cô vẫn không mặc quần áo truyền thống. Trước khi chuyển đổi cách ăn mặc, Ly thường mặc áo đen với nhiều hoạ tiết thêu nhiều màu sắc ở gấu áo, cổ, ống tay áo. Để phù hợp với áo mặc bên ngoài, cô mặc váy ba tầng với những hoạ tiết thêu. Nhu những người phụ nữ Dao thế hệ trước, cô vấn tóc và quấn khăn đến trên lông mày bằng khăn vấn màu đỏ. 
"Bây giờ rất ít người tụ thêu quần áo của mình. Nếu bận thì phải đii mua với giá rất đắt. Nhìn bộ quần áo người Kinh tôi đang mặc đây này, tôi mua ở chợ, nó rẻ hơn và dễ tìm mua hơn là quần áo người Dao" một người mẹ trẻ nói.

Cũng như những người Dao, phụ nũ người H'mong ở vùng nghiên cưu hiếm khi mặc những bộ quần áo truyền thống của dân tộc họ. "Em chưa bao giờ mặc quần áo người H'mong đến trường". Thía, học sinh người H'mong 20 tuổi, đang học ở trường trung học phổ thông Đình Cả, thị trấn Võ Nhai nói. "Nó nặng, khó giặt và đắt”. Thía thêm vào khi nói về bộ váy có 3 áo và váy màu đen mà nhiều phụ nũ già ở đây đã mặc. Hơn nữa, cô thích mặc quần bò xanh, áo hoa phù hợp với thân hình mánh mai của cô.

Những năm gần đây áo sơ mi, quần âu đã trở nên phổ biến ở thanh niên đặc biệt là những người có co hội đỉ học ở ngoài quê hương mình. "Chúng tôi chỉ mặc quần áo truyền thống một lần một năm trong dịp Tết” một người phụ nữ thế hệ thanh niên nói.

Trong khi trang phục đang thay đổi ở thanh niên dân tộc thì thế hệ phụ nữ lúa tuổi 40 trở lên vẫn giữ những bộ quần áo truyền thống.

"Nên có ít nhất một người trong gia đình vẫn tiếp tục mặc bộ quần áo truyền thống. Vợ của tôi vẫn mặc chúng, cô ta giữ lại truyền thống của dân tộc" Hữu thêm vào, người đàn ông Dao này luôn thuyết phục vợ mặc quần áo truyền thống của người Dao.

"Tôi không thể mặc áo sơ mi và quần hai ống như thanh niên. Tôi mặc quần áo đó sẽ rất buồn cười. Mọi người sẽ cười tôi” Vợ Hữu, phụ nữ ở độ tuổi 50.

Câu hỏi liệu người Dao và H'mong có tiếp tục giữ gìn trang phục truyền thống của dân tộc mình không, ý kiến của Ly một phụ nữ người Dao tỏ ý rằng mặc quần áo người Kinh phù họp với cuộc sống hàng ngày còn quần áo người Dao vẫn có thể là thời trang: "Khi em già hơn, như là khi thành bà, em sẽ mặc quần áo Dao”- Lỵ nói và cười.

Địa điểm nghiên cứu có nhiều dân tộc khác nhau sinh sống. Phong tục tập quán và sinh hoạt của Người Kinh tương tự như người Tày và Nùng cùng địa bàn, mô hình định cư mới cho thấy người Kinh cùng chung sống với người Tày và người Nùng hoà hợp hơn sự chung sống với người Dao và người H'mong. Ấn tượng chung là sự tác động lẫn nhau về mặt xã hội của các nhóm dân tộc Kinh và Tày, Nùng trong vùng nghiên cứu khá tốt, ví dụ ý kiến của lãnh đạo uỷ ban nhân dân huyện Tràng Xá:

... Hiện nay rất khó phân biệt người Tày hay Nùng với người Kinh. Thanh niên người Tày và Nùng không còn nói tiếng bản ngữ của họ. Họ chỉ nói tiếng Kinh. 
Không có vấn đề gì trong giao tiếp. Họ trở thành bạn bè, chơi với nhau và chia sẻ kiến thức về các hoạt động làm kinh tế. Nhu' tôi được biết, người H'mong và người Dao không như vạy. Sự giao tiếp giữa hai nhóm người này và người Kinh vẫn còn là vấn đề. Người Dao và H'mong vẫn đi sau người Kinh về phát triển kinh tế. Họ vẫn còn sụ khoảng cách với cuộc sống xã hội...

Đám cưới giữa người Kinh với người Dao hoặc giữa người Kinh với người H'mong không phổ biến như người Kinh cưới người Tày hoặc Nùng (chi tiết hơn ở chương 5). Mỗi làng nghiên cứu có một nhóm dân tộc vượt trội hơn. Ngoại trừ có hai làng pha tạp ở nhóm A (làng A1 và A2). Trong hai làng này, khoảng 40\% số hộ là người Dao và số còn lại là người Kinh (bảng 5). Tuy nhiên người Kinh vẫn giữ vai trò quan trọng trong chính quyền và việc ra những quyết định.

Thay cho cái nhìn thiếu toàn diện về sự hoà hợp giữa người Kinh, H'mong và Dao, những ý kiến của một số người dân và lãnh đạo cộng đồng cho rằng sự trao đổi giữa các nhóm dân tộc đã tăng lên trong thời gian gần đây và sự thay đổi này vẫn sẽ tiếp diễn trong tương lai.

... Trước đây có rất nhiều ý kiến phản đối việc người Kinh và người Dao cưới nhau. Nhưng bây giờ đám cưới trở nên phổ biến. Ngày xua, người Kinh và Dao không làm việc cùng nhau. Chẳng hạn, trong các công việc tập thể, người Kinh có thể làm việc ở đây còn người Dao lại làm việc ở đằng kia. Con người không làm việc cùng nhau. Bây giờ khi làm việc tập thể người ta thường chia theo khu vực nhiêu hơn là chia theo nhóm dân tộc. Người Kinh và người Dao có cơ hội kết hợp với nhau. Chúng tôi chơi cùng nhau và kết bạn...

Nhàn, 20, nũu, Kinh, sinh viên đại học, làng A2

Cũng như vậy, cơ hội làm kinh tế tăng lên và sự đa dạng hoá về kinh tế dường như góp phần tăng cường sự trao đổi trong xã hội giữa các nhóm dân tộc.

Người dân tộc trong làng thường có những phần đất canh tác nhỏ hơn. Khi có thời gian nhàn rỗi ho đến làm việc cùng với chúng tôi. Chúng tôi thuê ho để họ giúp chúng tôi làm việc trên mảnh đất của chúng tôi. Chúng tôi có cơ hội để chia sẻ kinh nghiệm canh tác ngô. Ví du chất lượng của hạt giống ngô luôn bị thoái hoá theo thời gian. Chúng tôi có sản phẩm đầu ra cao hơn vì người nông dân luôn dùng giống mới. Người Dao tù̀ làng A5 rất thiết tha học diều này.

Trưởng xóm, Kinh, nam, làng B1, nhóm B

Vẫn tồn tại một số sự hiểu nhầm hoặc một chút phân biệt đối với dân tộc thiểu số. Một số người Kinh trong làng nghiên cứu - đặc biệt thế hệ người già - nói rằng họ sợ dân tộc thiểu số, đặc biệt là người Dao bởi vì họ tin rằng người Dao có "phép" và có khả năng bỏ bùa mê. Họ luôn nói đến sự hiện diện của thày cúng trong nghi lễ của người Dao, điều không có trong văn hoá của họ. Một người phụ nữ Kinh, 45 tuổi, làng B3 kể về câu chuyện đám cưới giữa phụ nữ người Kinh và đàn ông người Dao như sau: 
Đàn ông người Dao yêu phụ nũ người Kinh rất nhiều nhưng cô ta tù chối cưới anh ta. Anh ta tìm mọi cách để đặt bùa mê hoạc cô ta. Cuối cùng vì bùa mê cô ta đông ý cưới, xoá bỏ cả lời hứa của cô ta với cha mẹ. Việc này mới xảy ra gần đây.

Tương tự như thế, người Dao và H'mong diễn tả mối băn khoăn của họ về giao tiếp với người Kinh trong làng. Có nhiều lý do được đưa ra. Một vài người nói rằng họ sợ bị lạm dụng hoặc sợ người Kinh sẽ giành được lợi thế. Những người khác nói đến sự phân biệt, rào cản ngôn ngữ, sự khác nhau về bề ngoài, lối sống, coi đó như là những cản trở trong việc trao đổi giữa họ và người Kinh.

\section{Kinh tế và thu nhập - Các hoạt động thông thường}

Tất cả các làng trong địa điểm nghiên cứu đều làm nông nghiệp. Sản phẩm chính là lúa và ngô. Theo điều tra hộ gia đình $(\mathrm{N}=150)$ khoảng $81 \%$ hộ người Kinh canh tác lúa, 97\% người Dao và H'mong làm nghề này. Tỷ lệ hộ gia đình trồng ngô cao hơn. Gần $90 \%$ các hộ người Kinh trồng ngô. Hầu như tất cả các hộ người Dao và $95 \%$ người H'mong cũng trồng ngô. Trong địa điểm nghiên cứu, đỗ, lạc, bí và các loại rau khác cũng được trồng. Thêm vào đó, người nông dân ở nhóm $\mathrm{B}$ còn trồng mía. Điều tra hộ gia đình cho thấy $41 \%$ người Kinh và $79 \%$ người $\mathrm{H}$ 'mong trong nhóm $\mathrm{B}$ trồng mía. Ngoài ra, đến năm 2006, cây thanh hao hoa vàng cũng được trồng trên diện tích rất lớn cung cấp nguyên liệu để sản xuất thuốc chống sốt rét. Tuy nhiên, sau khi giá cả bất ngờ giảm vào đầu năm 2006, chỉ còn một số hộ gia đình đã đầu tư tiền tiếp tục trồng loại cây này.

Các mùa vụ đều ngắn hạn và trồng trọt theo lối chuyên canh. Trong khi một số người nông dân đã sử dụng máy cày thì việc dùng trâu trong sản xuất nông nghiệp vẫn còn phổ biến. Việc sử dụng đất canh tác và lựa chọn cây trồng phụ thuộc vào độ cao của đất canh tác và nguồn nước. Đất vùng thấp được dùng để trồng lúa. Người nông dân có thể trồng lúa một vụ/năm. Chỉ có một số ruộng ở làng $\mathrm{A} 1$ và $\mathrm{A} 2$ có thể trồng hai vụ một năm (làng người Kinh). Vùng đất cao hơn có đất màu mỡ dùng để trồng ngô, mía, lạc và đỗ. Đất canh tác gần nhà được dùng để trồng rau và cây ăn quả chẳng hạn như xoài, ổi, mít. Nước là vấn đề quan trọng với việc canh tác ở vùng đất này, đặc biệt là với nhóm $\mathrm{A}$. Có vài con suối nhỏ chảy qua làng ở nhóm $\mathrm{A}$ nhưng nó cạn nước vào mùa hè và mùa thu. Vài năm trước đây chỉ có một số lượng nhỏ nông dân nhóm A cố gắng góp vốn để xây dựng hệ thống tưới tiêu trong khu đất canh tác với hỗ trợ kỹ thuật của phòng nông nghiệp huyện. Mỗi hộ gia đình được hưởng lợi từ việc tưới tiêu phải đóng góp 750.000 đồng. Một số nông dân nghèo khi trả lời phỏng vấn đã nói rằng họ không thể góp số tiền lớn như vậy nếu không có sự trợ giúp của Chính phủ. Một người lãnh đạo ở xã Phương Giao giải thích về những khó khăn trong canh tác như sau:

... Thiếu nước luôn là vấn đề của canh tác ở đây. Chúng tôi trồng lúa trên ruộng bậc thang. Chúng tôi không có đủ nước... có hệ thống tưới tiêu nhưng do các 
làng tự xây dựng nên không phù hợp với tiêu chuẩn về kỹ thuật. Hệ thống tưới tiêu hiện tại không có hiệu quả. Chưa đến một nửa số hộ ở xã Phương Giao có thể trông lúa hai vụ/ một năm...

Lúa được trồng rất phổ biến ở vùng nghiên cứu. Lúa năng suất cao được trồng ở những vùng đất có hệ thống tưới tiêu. Hầu hết thóc thu hoạch để tự cung cấp. Chỉ có một số người nông dân chịu khó làm dư thừa, hầu hết trong số này là người Kinh. Trong số mẫu điều tra hộ gia đình, $25 \%$ hộ người Kinh nhóm $\mathrm{A}$ và $35 \%$ hộ người Kinh nhóm $\mathrm{B}$ trả lời có bán lúa, chỉ $5 \%$ người Dao và $18 \%$ người H'mong có thóc dư thừa để bán. Tất cả các làng người Kinh tại nơi nghiên cứu đều có ít nhất một máy xay chứng tỏ họ đã tiếp cận được với cơ khí hoá. Trong khi đó, sản xuất thủ công vẫn phổ biến ở làng người Dao và H'mong. Một số nông dân người Dao đã thuê những hàng xóm người Kinh xay xát lúa. Tiền công trả bằng lúa thay cho trả tiền mặt. Rau, đỗ, hoa quả cũng được trồng để phục vụ cho ăn uống hàng ngày và nếu có dư thừa thì họ bán ở chợ. Những người nông dân nhóm $\mathrm{B}$ trồng rau để bán phổ biến hơn nông dân nhóm $\mathrm{A}$. Có nơi cất giữ trong nhà và phương tiện giao thông sẵn có, chợ rau luôn thích hợp và mang lại lợi nhuận cho hầu hết những người nông dân.

Tỉnh Thái Nguyên nổi tiếng với chè nhưng chè không được trồng ở đây. Ngô và mía là hai sản phẩm quan trọng. Mía chỉ được trồng rộng rãi ở nhóm $\mathrm{B}$ vì loại này đòi hỏi một mùa tập trung nước. Ngô được dùng để chăn nuôi. Trong khi đó, mía thường được người nông dân sản xuất thành đường trước khi mang đi bán. Đường được sản xuất bằng cách cô đặc từ nước mía ép. Nhờ có sự cải thiện của đường liên xã, liên làng, hầu hết nông dân không phải mang sản phẩm của họ đến chợ. Những lái buôn từ thị trấn hoặc trung tâm xã đến mua trực tiếp sản phẩm của người nông dân và chở đi bằng xe công nông. Trong những năm vừa qua, gần 10 hộ gia đình người Kinh nhóm $\mathrm{B}$ đủ tiền mua xe công nông và bắt đầu kinh doanh. Điều này làm gia tăng mối quan hệ của họ với những nông dân dân tộc thiểu số cùng làng.

Nhìn chung tất cả những người lãnh đạo xã đều cho rằng sản phẩm mùa màng nhất là gạo ngô đã tăng lên trong những năm qua vì kiến thức kỹ thuật nông nghiệp, và sử dụng phân bón.

Kinh tế xóm tôi đã cải thiện rất nhiêu. Giá đường trước đây rất thấp. Mấy năm trước giá là 800 đồng/kg. Bây giờ có thể bán tù̀ 7.000 đến 8.000 đồng/kg. Hơn nũa, chúng tôi sử dụng ngô giống mới và năng suất tăng nhiêu. Với giống ngô cũ, năng suất $50-60 \mathrm{~kg} / \mathrm{sào}\left(360 \mathrm{~m}^{2}\right)$. Bây giờ dùng giống ngô mới trung bình $150 \mathrm{~kg} / \mathrm{sào}$.

- Trương xóm, nam, Kinh, làng B1, nhóm B

Năng suất và lợi nhuận cao từ các sản phẩm nông nghiệp không phải ở tất cả các làng trong địa điểm nghiên cứu đều có. Làng người Dao xa nhất (làng $\mathrm{A5}$ ) và một số hộ gia đình sống ở những vùng sâu phát triển kinh tế không đồng đều. Ở vùng sâu, khó khăn của họ dường như tăng lên. Chẳng hạn người Dao ở làng A5 có ít quyền trong việc đặt giá cả hơn khi bán ngô cho những lái buôn. Họ phải chấp 
nhận giá do lái buôn đưa ra vì đường đến làng họ khó đi hơn so với đường đến những làng khác ở nhóm $\mathrm{A}$, vì thế nông dân người Dao ở đây thường bán ngô với giá rẻ hơn từ 100-200 đồng/kg. Mặc dù thu nhập vụ mùa có tăng lên người nông dân vẫn khó khăn vì các sản phẩm của họ phụ thuộc rất lớn vào giá phân bón và thuốc trừ sâu. Hiện nay, giữa các làng chưa có sự thảo luận để thống nhất về việc sử dụng hóa chất cho mùa vụ nhằm bảo vệ môi trường.

... Phân bón được vận chuyển đến làng bằng xe tải, xe công nông hoặc xe máy. Nếu chúng tôi không sử dụng phân bón, sản lượng ngô và lúa rất thấp. Thỉnh thoảng chúng tôi cũng không thể mua phân hoá học. Trong quá khứ chúng tôi đãa không dùng phân bón hoá học. Chúng tôi chỉ sử dụng phân trâu nhưng phân trâu thì không đủ...

- Trương xóm, Dao, nam, làng A5, nhóm A

... Vâng, thu nhập của chúng tôi đã tăng so với năm 2000. Nhưng trên thực tế, không phải mọi thư đều tăng. Thu nhập tù̀ việc bán các sản phẩm dường nhu tăng lên nhưng lợi nhuận thực sự vẫn còn thấp. Chúng tôi đã phải chi nhiều tiên cho việc mua phân bón và giống...

- Trương xóm, Kinh, nam, làng B2, nhóm B

Để có thêm thu nhập ngoài việc bán các sản phẩm như ngô, mía các hộ gia đình còn nuôi gia súc, gia cầm như trâu, lợn và gà (Bảng 10 ). Theo điều tra, hơn một nửa số hộ gia đình trong vùng nghiên cứu nuôi lợn. Phần lớn người nông dân không đầu tư gì hơn vài con lợn một lần. Có vài hộ gia đình (hầu hết là người Kinh) bắt đầu đầu tư bằng nuôi gia súc với quy mô tương đối lớn. Nhóm nghiên cứu đã gặp một cặp vợ chồng trẻ hơn 30 tuổi ở làng $\mathrm{A} 2$ đã đầu tư nuôi 22 con lợn. Để chăn một lứa lợn mất khoảng 4-5 tháng. Một tạ lợn hơi trung bình bán được 1 triệu đồng. Chăn nuôi có lãi nhiều hơn canh tác nên cặp vợ chồng này đã dừng việc canh tác. Họ chỉ trồng lúa để tự tiêu dùng. Gần đây cặp vợ chồng này đã bắt đầu bán thức ăn gia súc trong làng, thêm vào đó họ buôn bán lợn. Thiếu vốn và kiến thức là trở ngại để bắt đầu những nghề như thế này.

Bảng 10. Nguồn thu nhập chính theo dân tộc và nhóm, 2006

\begin{tabular}{lccccc}
\hline \multirow{2}{*}{$\begin{array}{c}\text { \% hộ gia đình có thu nhập } \\
\text { chủ yếu từ... }\end{array}$} & $\begin{array}{c}\text { Tổng số } \\
(\mathrm{N}=74)\end{array}$ & $\begin{array}{c}\text { Nhóm } \mathbf{A} \\
(\mathrm{N}=37)\end{array}$ & Nhóm B & Dao & H'mong \\
\cline { 2 - 5 } & 76 & 84 & 68 & 61 & 71 \\
\hline Lúa & 77 & 73 & 81 & 90 & 97 \\
Loại cây mùa khác & 68 & 65 & 70 & 47 & 66 \\
Gia súc, gia cầm & 27 & 38 & 16 & 16 & 11 \\
Lao động thuê nông nghiệp & 20 & 30 & 11 & 3 & 0 \\
Lao động thuê phi nông nghiệp & 11 & 3 & 19 & 0 & 0 \\
Buôn bán & & & & & \\
\hline
\end{tabular}

Nguồn: Điều tra hộ gia đình, 2006 
Tiền công làm thuê trong lao động nông nghiệp là nguồn thu nhập khác của hộ gia đình ở đây. Tiền công lao động hàng ngày ở Phương Giao thường thấp hơn ở Tràng Xá. Số tiền này phụ thuộc vào việc người lao động có hay không ăn trưa mà dao động từ 20.000 đến 30.000 đồng/ngày. Những người trong làng thường đi làm thuê ngay sau khi mùa vụ kết thúc. Với những hộ gia đình không có nhiều đất canh tác, người dân có thể làm thuê trong cả năm. Một số hộ gia đình nói họ chỉ kiếm tiền bằng lao động làm thuê nông nghiệp khi họ hết thóc hoặc cần tiền để mua gạo. Những địa điểm làm thuê có thể ở trong làng hoặc trong xã (Nhóm $\mathrm{B}$ luôn có nhu cầu lao động cao hơn nhóm $\mathrm{A}$ ), ở thị trấn hoặc ở huyện khác. Một số nam giới ở độ tuổi 20 đến 30 thường làm công việc xẻ gỗ. Loại công việc này yêu cầu phải đi vào rừng sâu, phải sống xa nhà, khoảng 2 tuần mới có một lần về thăm gia đình (thảo luận sâu hơn ở chương 5). Nhìn chung thu nhập chính của người dân ở đây là thu nhập từ nông nghiệp. Cả người Kinh và người dân tộc thiểu số đều phụ thuộc trực tiếp vào sản xuất nông nghiệp, họ là những nông dân hoặc những người làm thuê. Điểm quan trọng là người Kinh có nguồn thu nhập phong phú hơn người những dân tộc khác, hộ gia đình người Kinh có thể kiếm được tiền từ những nghề dịch vụ, buôn bán, họ có công lao động phi nông nghiệp nhiều hơn người Dao.

Bảng 11. Thu nhập hộ gia đình theo dân tộc và nhóm, 2006

\begin{tabular}{|c|c|c|c|c|c|}
\hline \multirow[b]{2}{*}{ Thu nhập (triệu đồng) } & \multicolumn{3}{|c|}{ Kinh } & \multirow[b]{2}{*}{$\begin{array}{c}\text { Dao } \\
(\mathrm{N}=38)\end{array}$} & \multirow{2}{*}{$\begin{array}{l}\text { H'mong } \\
(\mathrm{N}=38)\end{array}$} \\
\hline & $\begin{array}{c}\text { Tổng số } \\
(\mathrm{N}=74)\end{array}$ & $\begin{array}{c}\text { Nhóm A } \\
(\mathrm{N}=37)\end{array}$ & $\begin{array}{c}\text { Nhóm B } \\
(\mathrm{N}=37)\end{array}$ & & \\
\hline Nhỏ nhất & 0.6 & 0.6 & 2 & 0.1 & 1 \\
\hline 25th percentile & 4 & 4 & 6 & 3 & 5 \\
\hline 50th percentile & 8 & 7 & 15 & 6 & 10 \\
\hline 75th percentile & 20 & 15 & 20 & 10 & 15 \\
\hline Lớn nhất & 500 & 51 & 500 & 18 & 35 \\
\hline Thu nhâpp trung bình & 18.6 & 8.5 & 28.5 & 6.3 & 11.3 \\
\hline
\end{tabular}

Nguồn: Điều tra hộ gia đình, 2006

Những hộ người Kinh ở nhóm $\mathrm{A}$ và $\mathrm{B}$ có nhiều nghề khác nhau, từ việc bán tạp hoá nhỏ, bán thực phẩm và nước giải khát đến mở cửa hiệu may đo. Những cửa hàng này thường nằm trên con đường liên xóm. Những hộ gia đình này cũng như các hộ kinh doanh phi nông nghiệp khác đều không thuê nhân công. Cơ hội làm kinh tế phi nông nghiệp ở Phương Giao thực sự bị hạn chế nhưng ở trung tâm của Tràng Xá lại phát triển. Ở đây có nhiều cửa hàng bán những đồ xa xỉ như bộ bàn ghế salon, xe máy và những bộ áo cưới kiểu phương Tây. Kinh tế ở thị trấn Đình Cả có sự phát triển vượt trội bởi kinh doanh của những hộ gia đình và đây là trung tâm hành chính của huyện, nơi làm việc của chính quyền địa phương. Thực chất, kinh tế phi nông nghiệp theo nghĩa 
rộng không tồn tại trong vòng bán kính $20 \mathrm{~km}$ ở vùng nghiên cứu. Chỉ có một nhà máy gần đây nhất là nhà máy xi măng La Hiên nằm trên quốc lộ $1 \mathrm{~B}$ ở ranh giới giữa Võ Nhai và Đồng Hỷ (trên đường đi thành phố Thái Nguyên), và có một nhà máy khác đang xây dựng gần nhà máy xi măng La Hiên. Nếu có nhiều nhà máy hơn, sự đa dạng hoá về kinh tế sẽ tăng lên, cấu trúc nghề nghiệp của người dân trong vùng sẽ có cơ hội thay đổi.

Bảng 11 mô tả sự phân bố thu nhập của người dân trong làng. Khi ước lượng cần hết sức thận trọng bởi vì kích cỡ nhỏ nhưng rõ ràng những hộ gia đình người Kinh nhóm $\mathrm{B}$ có kinh tế tốt hơn những hộ người Kinh ở nhóm $\mathrm{A}$ và những hộ dân tộc khác. Tính trung bình, so sánh với người Kinh và H'mong trong cùng làng, thu nhập của những hộ người Dao là thấp nhất. Điều làm chúng tôi ngạc nhiên là ở nhóm $\mathrm{A}$ những hộ người H'mong lại có thu nhập cao hơn người Kinh. Sự hạn chế của số liệu khiến chúng tôi chưa thể kết luận rằng có sự đánh giá quá cao người H'mong và đánh giá thấp người Kinh nhóm A. Điều thú vị chúng tôi quan sát được là thu nhập hộ gia đình giữa các dân tộc thiểu số không có sự chênh lệch lớn, trong khi đó thu nhập của các hộ người Kinh có sự chênh lệch rất lớn, lớn đến mức người ta có thể nghi ngờ những con số này.

\section{Việc tham gia vào chương trình xoá đói giảm nghèo}

Vùng nghiên cứu được phân vào loại vùng khó khăn và xa nhất ở Việt Nam (xem hộp 3.2 về cách phân loại hộ và xã nghèo) vì vậy họ nhận được sự hỗ trợ của các chương trình tác động làm giảm nghèo như chương trình xoá đói giảm nghèo, chương trình 135 và quyết định 139 (quỹ chăm sóc sức khoẻ cho người nghèo). Lợi ích chính của chương trình này là phát triển cơ sở vật chất, hỗ trợ cho giáo dục và chăm sóc sức khoẻ, thẻ tín dụng nhỏ và phát triển nông nghiệp.

Chương trình 135 dược tiến hành tù̀ năm 1999. Tù chương trình 135 chúng tôi nhận được tù̀ 500 đến 700 triệu đồng mỗi năm. Xã chúng tôi cũng được hỗ trợ bởi quyết định 139. Chương trình xoá đói giảm nghèo cũng được triển khai trong xã của chúng tôi. Nhũng người dân có thể vay tiền tù ngân hàng chính sách với lãi suất thấp.

- Lãnh đạo Uỷ ban nhân dân xã Phương Giao

\section{Hộp 3.2: Làm thế nào để xác định được xã nghèo và hộ nghèo}

Việc xác định xã vùng sâu và khó khăn nhất được hưởng lợi chương trình 135 dụa trên việc phối hợp nhiều tiêu chí. Trong đó bao gồm vùng sâu, độ cao so với mặt nước biển, khoảng cách đến trung tâm huyện, điều kiện sản xuất khó khăn, tỷ lệ hộ nghèo cao hơn 30\% theo tiêu chuẩn của Bộ Lao động Thương binh Xã hội. Danh sách này được làm tù dưới lên qua nhiều giai đoạn. Trong giai đoạn đầu giữa năm 1998 và 2000 có 1.715 xã được lựa chọn để tham gia chương trình 135. Đến năm 2002, tổng số các xã nhận được chương 
trình 135 là 2.362 xã.

Lại có một danh sách khác được sắp xếp theo chương trình 135 (được biết đến như là chương trình xoá đói giảm nghèo). Trong danh sách này, các xã phải có ít nhất 40\% các hộ nghèo theo tiêu chuẩn của Bộ Lao động Thương binh Xã hội. Những xã không có cơ sở hạ tầng cơ bản cũng được thống kê vào danh sách.

Việc phân loại xã nghèo, hộ nghèo được thục hiện ở tất cả các tỉnh. Việc chúng nhận hộ nghèo dụa trên quyết định của chính quyền thôn, xã sư dụng phương pháp của Bộ Lao động Thương binh Xã hội. Theo tiêu chí ban đầu, hộ gia đình được phân loại là hộ nghèo có thu nhập thấp hơn 150.000 đồng/người/tháng ở thành thị; 100.000 đồng/người/tháng ở nông thôn và 80.000 đồng/người/tháng ở miền núi và vùng sâu. Năm 2004, tiêu chí này được điều chỉnh là 200.000 đồng/người/tháng vùng nông thôn; 260.000 đồng/người/tháng ở vùng thành thị.

Tuy nhiên trên thục tế ít hộ gia đình được điều tra để tính thu nhập. Việc xác định có nhận được miễn giảm học phí hay thẻ khám chũa bệnh dựa trên phương pháp tham gia của cộng đồng. Mỗi xã, bao gồm một số làng, trong làng có tù vài chục đến hàng trăm hộ gia đình. Thu nhập của tùng hộ trong làng dựa trên sụ bàn bạc, thậm chí là bình bầu, sau đó, dựa trên múc độ nghèo của từng hộ, người dân sẽ phân chia những quyền lọi cấp trên đưa xuống.

Một số nơi quan tâm đến thu nhập dụa trên tiêu chuẩn của Bộ Lao động Thương binh Xã hội, để làm việc này, những hiểu biết của người hàng xóm được coi là rất quan trọng. Đánh giá hộ nghèo có sụ tham gia của cộng đồng, tù đó xác định những hộ nghèo nhất, sau đó sư dụng hệ thống chính quyền địa phương để phân chia lợi ích là cách làm phổ biến. Cách làm này cũng dựa trên sụ phân chia đất đai sản xuất nông nghiệp, bằng chúng về sụ phân bổ này là một cơ sở chắc chắn để xác định hộ cộn nghèo.

Nguồn: Ngân hàng thế giới (2004).

Chương trình xoá đói giảm nghèo được tiến hành từ những năm 1990. Theo điều tra, không phải tất cả các hộ gia đình đều nhận thức được về chương trình và lợi ích của họ. Ví dụ, người cung cấp thông tin chính từ hộ người Kinh dường như có hiểu biết nhiều hơn những người dân tộc. $81 \%$ người Kinh nhóm $\mathrm{A}$ và $84 \%$ người Kinh nhóm $\mathrm{B}$ trả lời rằng họ đã nghe về chương trình xoá đói giảm nghèo, trong khi chỉ có $55 \%$ người Dao và $71 \%$ người H'mong biết về điều đó. 
... Những người dân tộc thiểu số hạn chế nhận thức về sự hỗ trợ, họ chỉ có thể nghe tù̀ chính quyền. Vì vậy họ mất đi nhũng sự hỗ trợ tù̀ chương trình phát triển nông nghiệp, hỗ trợ để sủa chũa nhà và thúc đẩy chăm sóc trâu bò...

- Nhân viên chũ thập đỏ, người Kinh, nam, nhóm A

Bảng 12. Sự phân bố những lợi ích hộ gia đình nhận được từ chương trình giảm nghèo

\begin{tabular}{lcccccc}
\hline & \multicolumn{3}{c}{ Kinh } & Dao & H'mong \\
\cline { 2 - 4 } \% hộ gia đình nhận được lợi ích & Tổng số & Nhóm A & Nhóm B & & \\
& $(\mathrm{N}=74)$ & $(\mathrm{N}=37)$ & $(\mathrm{N}=37)$ & $(\mathrm{N}=38)$ & $(\mathrm{N}=38)$ \\
\hline Chăm sóc sức khoẻ miễn phí & 72 & 62 & 81 & 68 & 71 \\
Cơ sở hạ tầng mới & 68 & 65 & 70 & 47 & 71 \\
Vay với lãi suất thấp & 53 & 60 & 46 & 74 & 50 \\
Miễn giảm học phí & 51 & 43 & 60 & 32 & 45 \\
Hỗ trợ sản xuất rừng và nông nghiệp & 18 & 22 & 14 & 18 & 24 \\
Sửa chữa/xây nhà & 5 & 11 & 0 & 13 & 8 \\
Ngân hàng bò & 8 & 8 & 8 & 8 & 5 \\
Hỗ trợ đất sản xuất & 4 & 8 & 0 & 0 & 0 \\
Hỗ trợ đi lại & 0 & 0 & 0 & 3 & 3 \\
\hline
\end{tabular}

Nguồn: Điều tra hộ gia đình năm 2006

Bảng 12 mô tả những lợi ích người dân được hưởng từ chương trình xoá đói giảm nghèo. Hộ gia đình thường trả lời họ đã nhận được lợi ích từ việc khám chữa bệnh miễn phí, cơ sở hạ tầng mới, thẻ tín dụng nhỏ, giảm học phí và phát triển nông nghiệp. Chỉ có số lượng nhỏ hộ gia đình nói rằng họ nhận được sự hỗ trợ để sửa nhà, vay vốn để mua trâu, hỗ trợ phương tiện và hỗ trợ đất canh tác. Những ý kiến sau gợi ý giải thích tại sao một số lợi ích lại bị hạn chế hơn những loại khác.

Người dân ở đây thích đầu tư vào phát triển bò. Ví dụ, người dân muốn có một lúa tù 3 đến 4 con bò. Một cách là ho tiết kiệm tiền để mua bò. Còn có cách khác là vay tiền để mua thêm 2-3 con bò nữa. Nhưng rất khó được phê duyệt cho vay vốn để mua trâu bò. Mất nhiều thời gian để có được sự phê duyệt tù̀ huyện đến tỉnh và ngân hàng... người dân không thể chờ đợi. Họ đem tiên tiết kiệm được dư định để mua bò đi mua nhũ̃ng thứ cần thiết khác...

- Trương xóm, nam, Kinh, làng B2, nhóm B

Tất cả các hộ gia đình trong địa điểm nghiên cứu, không tính đến có được xác định là hộ nghèo hay không đều được chăm sóc sức khoẻ miễn phí ở trạm y tế xã (miễn phí tiền khám, người dân vẫn phải trả tiền thuốc). Theo điều tra, tỷ lệ hộ gia đình ở nhóm $\mathrm{B}$ nhận được lợi ích chăm sóc sức khoẻ nhiều hơn so với nhóm $\mathrm{A}$. Chúng tôi không thấy có sự khác biệt giữa người Kinh và người dân tộc thiểu số về việc nhận được 
dịch vụ chăm sóc sức khoẻ. Tỷ lệ lớn của đầu tư chương trình 135 là cơ sở hạ tầng ở xóm và xã. Tỷ lệ hộ gia đình (không tính đến người Kinh hay dân tộc) nhóm $\mathrm{B}$ nhận được lợi ích từ cơ sở hạ tầng mới cao hơn nhóm $\mathrm{A}$. Gần một nửa hộ gia đình người Dao trong mẫu nghiên cứu nhận thấy họ nhận được lợi ích từ cơ sở hạ tầng mới. Điều này phản ánh thực tế trong các làng nghiên cứu, người Dao ít tiếp cận và kém phát triển hơn. Người trưởng bản của một bản người Dao đã nói rằng mặc dù chương trình 135 có triển khai nhưng người trong làng vẫn phải đóng góp tiền để xây dựng đường liên bản. Những ý kiến sau cho thấy sự minh bạch và tính kiên định của quỹ dành cho chương trình xoá đói giảm nghèo được phân bổ như thế nào.

Con đường ở làng của chúng tôi xây dựng tù năm 2004. Tất cả các hộ gia đình đã phải đóng góp. Chúng tôi không nhận được bất kỳ sự hỗ trợ nào. Mỗi người phải đóng 20.000 đông và chúng tôi xây dựng con đường này mất 2 triệu đông.

- Trưởng xóm, Dao, nam, làng A4, nhóm A

Theo bảng 12, 60\% hộ người Kinh và 74\% hộ người Dao nhóm A được hưởng lợi từ việc vay vốn với lãi suất thấp cao hơn so với nhóm $\mathrm{B}(46 \%$ Kinh và $50 \%$ H'mong). Hơn nữa, tỷ lệ hộ gia đình ở nhóm $\mathrm{B}$ nói được hưởng lợi từ giáo dục nhiều hơn nhóm $\mathrm{A}$. Trong khuôn khổ từng nhóm, những hộ gia đình người Kinh báo cáo được hưởng lợi trong việc giảm học phí nhiều hơn người dân tộc thiểu số. Trong tất cả những lợi ích từ chương trình giảm nghèo, chỉ có quỹ dành cho sửa chữa nhà ở, hộ gia đình người dân tộc nhận được nhiều lợi ích hơn hộ gia đình người Kinh. 13\% hộ người Dao và 8\% hộ người H’mong nhận được tiền hỗ trợ cho việc sửa nhà.

\section{Hộp 3.3: Hỗ trộ nhà ở cho những hộ nghèo: Có thực sự là may mắn?}

Thanh như thấy mình trúng xổ số khi ông trưởng thôn thông báo với cô rằng cô nhận được 6 triệu đồng để sủa nhà tạm của mình. Tiền được cấp tù chương trình 135 cho xã Tràng Xá, chương trình có tù năm 1999. Hàng năm xã lụa chọn số lượng nhỏ những hộ nghèo để hỗ trợ sưa nhà. Điều này phụ thuộc vào sụ nhận xét đúng đắn của lãnh đạo thôn để quyết định sẽ chi cho ai 6 triệu đồng.

Thanh là người Nùng, năm nay cô 29 tuổi, kết hôn với người Kinh và cuộc sống của cô có khó khăn. Cả hai vợ chồng cô đều có học vấn thấp. Thu nhập của họ chỉ dựa vào đồng áng. Bố chồng sống cùng vợ chồng cô bị tai biến mạch máu não hiện có rối loạn tâm thần và động kinh. Ông ấy không thể lao động. Thu nhập của Thanh và chồng cô có được tù bán mía và ngô hiếm khi đủ để nuôi cả gia đình, nên không thể có đủ tiền để sưa nhà.

Với Thanh, ban đầu, được vay 6 triệu đồng là thục sụ may mắn. Cô bắt đầu tính toán xem sẽ sưa nhà như thế nào. Tuy nhiên, mọi chuyện không đơn giản như Thanh đã hy vọng. Cô được biết là chỉ nhận được tiền sưa nhà sau khi 
cô đã sưa nhà xong và được chính quyền xã chúng nhận cô đã chi số tiền đó vào sưa nhà. Đây là quy tắc thêm vào của xã để đảm bảo người dân không lạm dụng tiền quỹ. Lẽ ra cách làm này đáng được ca ngợi nhưng nó lại làm cho những người nhận được tiền hỗ trợ sưa nhà đau đầu và thêm khó khăn. Với trường hợp của Thanh, điều này làm cho cô trở nên mắc nọ nhiều hơn.

Thanh phải vay tiền từ người cho vay lãi tư nhân trong làng để sủa mái nhà và xây lại bếp tách riêng khỏi nhà chính. Cô phải trả 3\% lãi suất cao hơn nhiều so với vay tù ngân hàng chính sách. Gia đình nhận được tiền tù chính quyền xã vài tháng sau khi họ đã có món nọ lớn hơn số tiền được nhận mặc dù họ không chi quá 6 triệu đồng.

Năm vừa qua, tỷ lệ hộ gia đình nhóm $\mathrm{A}(60 \%$ người Kinh và $74 \%$ người Dao) được vay tiền từ chương trình tín dụng nhiều hơn so với nhóm $\mathrm{B}$. Ở nhóm $\mathrm{B}$ tỷ lệ này là $46 \%$ người Kinh và $50 \%$ người H'mong. Hầu hết các hộ gia đình vay tiền từ ngân hàng chính sách. Những người đi vay được phép vay tối đa 7 triệu đồng với lãi suất thấp là $1 \%$. Tuy nhiên trên thực tế, hầu hết những người dân trong làng chỉ có thể vay 3 triệu đồng từ ngân hàng. Một số người nông dân cho rằng 3 triệu là số tiền không đủ để đầu tư làm một việc gì. Vì vậy, họ sẵn sàng trả lãi suất cao hơn để vay từ tư nhân với lãi suất cao thường từ 3 đến $4 \%$. Tuy nhiên việc vay tiền từ tư nhân phụ thuộc nhiều vào vị trí của họ trong xã hội. Sau đây là ý kiến nói về việc này:

Rất khó để chúng tôi vay được tiền. Gia đình bà ấy (hàng xóm) có con trai là trương xóm nên họ có thể vay tù những người khác. Nếu gia đình chúng tôi muốn vay, họ không dám chắc chắn là chúng tôi có thể trả lại tiên vì vậy họ không muốn cho chúng tôi vay tiền.

- Hoa, Kinh, nũ , 19 tuổi, làng A3, nhóm A

Với khoản tiền lớn hơn, khoảng từ 20 đến 30 triệu đồng người dân thường vay từ Ngân hàng Phát triển Nông nghiệp. Chỉ có vài người được chính quyền xác nhận để vay vốn. Những khó khăn để tiếp cận với việc vay vốn được nói tới như sau:

Chúng tôi vay 10 triệu đồng tù̀ Ngân hàng Phát triển Nông nghiệp để mua hai con trâu và mấy con lợn. Không dễ để vay được. Tôi chỉ vay được sau khi ngân hàng đã đánh giá nhà tôi là hộ nghèo... Tôi muốn vay nhiêu hơn 10 triệu để phát triển kinh tế nhưng ngân hàng không phê duyệt. Họ sợ chúng tôi không thể hoàn trả tiên.

- Sang, Kinh, nam, 54 tuổi, làng B1, nhóm B

Nhìn chung người dân trong địa điểm nghiên cứu nhận thấy điều kiện sống của họ đã được cải thiện trong năm năm qua không kể đến việc họ có hiểu biết hoặc tham gia vào chương trình giảm nghèo hay không. Trong số những hộ gia đình, $70 \%$ số hộ đồng ý rằng cuộc sống của họ đã thay đổi tốt hơn. Cả người Kinh và H'mong ở nhóm $\mathrm{B}$ đều 
cho rằng việc cải thiện cuộc sống của họ dường như tốt hơn những người ở nhóm $\mathrm{A}$. Khoảng $4 / 5$ người Kinh và $3 / 4$ hộ người $\mathrm{H}^{\prime}$ mong ở nhóm $\mathrm{B}$ tin rằng điều kiện sống đã tốt hơn trong 5 năm qua so với $70 \%$ người Kinh và Dao ở nhóm A. Điều này cũng thống nhất với những quan sát về mức độ phát triển cơ sở hạ tầng và điều kiện kinh tế. Nhóm $\mathrm{B}$ có điều kiện kinh tế đa dạng hơn và việc tiếp cận với thị trấn dễ dàng hơn.

Mặc dù về tổng thể một cách khách quan, điều kiện sống đã được cải thiện nhưng nghèo vẫn còn nhiều ở vùng nghiên cứu. Nghèo đói thể hiện nhiều khía cạnh. Nguy cơ mất an ninh thực phẩm và đói nghèo nhìn chung đã giảm nhưng vẫn còn là vấn đề ở một số làng trong vùng nghiên cứu đặc biệt là những làng của người Dao. Ý kiến sau đây là khá điển hình:

Thực phẩm ở đây chỉ đủ cho 7 đến 8 tháng trong một năm. Khi hết gạo chúng tôi ăn ngô. Trong khoảng 4 đến 5 tháng, chúng tôi có thực phẩm dự trũ. Chúng tôi tìm kiếm thêm thực phẩm tù̀ rùng... Một số loại có thể ăn được nhu củ tù hoạc sắn. Tuy nhiên, bây giờ tìm những loại thức ăn này khó hơn trước. Thỉnh thoảng chúng tôi phải mất cả ngày để tìm thức ăn.

- Sơn, Dao, nũu, 24 tuổi, đã có chông, làng A5, xóm A

Nghèo đói còn đe doạ vì những cải thiện hiện nay trong cuộc sống chưa thật bền vững. Mặc dù một số người dân có đủ thực phẩm để sống trong cả năm và cảm thấy cuộc sống của họ đã cải thiện nhưng họ dường như vẫn sống bên bờ vực của sự nghèo đói. Những cú sốc về kinh tế chẳng hạn như ốm đau, mất mùa có thể đẩy họ trở lại nghèo đói một lần nữa.

Cuộc sống trở nên khó khăn hơn. Bây giờ chúng tôi thiếu gạo it nhất là 4 tháng trong năm. Cuối cùng chúng tôi cũng kiếm sống bằng cách săn băn, bán gà và lợn. Tù tiên đó chúng tôi mua gạo... chúng tôi lo ăn hàng tháng. Tháng này chúng tôi có thể bán gà và lợn. Sang tháng chúng tôi phải nghĩ cách khác để nuôi con cái.

- Xuân, Dao, nũu, 26 tuổi, có chồng, làng Al, nhóm A

Nghèo tác động đến nhiều lĩnh vực khác nhau trong cuộc sống của người dân. Nhiều người dân đã nói về phúc lợi kinh tế xã hội của họ tương đương với những người láng giềng. Mặc dù có nhiều gia đình đã được đáp ứng những nhu cầu cơ bản như đủ thức ăn, nước dùng, quần áo, nhà ở nhưng vài người trong số họ vẫn cảm thấy thiếu thốn vì họ đã không thể cố gắng để mua xe máy, tivi hay đầu DVD.

Chúng tôi không mua thịt hàng ngày. Thường xuyên chúng tôi ăn cơm với rau. Chúng tôi muốn tiết kiệm tiên để mua tivi. Bây giờ chúng tôi phải xem tivi nhờ nhà hàng xóm, không thích lăm.

- Thực, Kinh, nũu, 54 tuổi, làng B1, nhóm B

Theo điều tra hộ gia đình, những người cung cấp thông tin chính đã được phỏng vấn để đánh giá về sự tương quan về phúc lợi so với những làng khác. Ở nhóm $\mathrm{A}$ (cả 
người Kinh và người Dao) phúc lợi của họ thấp hơn mức trung bình và họ đang ở mức nghèo. $72.3 \%$ người Kinh và $52.6 \%$ người Dao cho rằng họ có mức sống thấp hơn những người hàng xóm. Trong khi đó những người ở nhóm $\mathrm{B}$ cho rằng họ có mức sống trung bình.

Những thông tin trên cho thấy hai xã này làm nông nghiệp là nghề chính. Nhìn chung họ có thể tiêu biểu cho những xã có nhiều dân tộc ở vùng núi phía bắc Việt Nam trong điều kiện kinh tế chuyển đổi hơn là những làng có cả người Kinh và người dân tộc thiểu số ở những vùng xa xôi hơn. Sự khác nhau này có thể tác động đến những lớp người trẻ trong quá trình chuyển sang tuổi thanh niên. 


\section{Chương 4 \\ HỌC TẬP VÀ QUÁ TRİNH CHUYỂN DỊCH ĐẾN VIỆC LÀM}

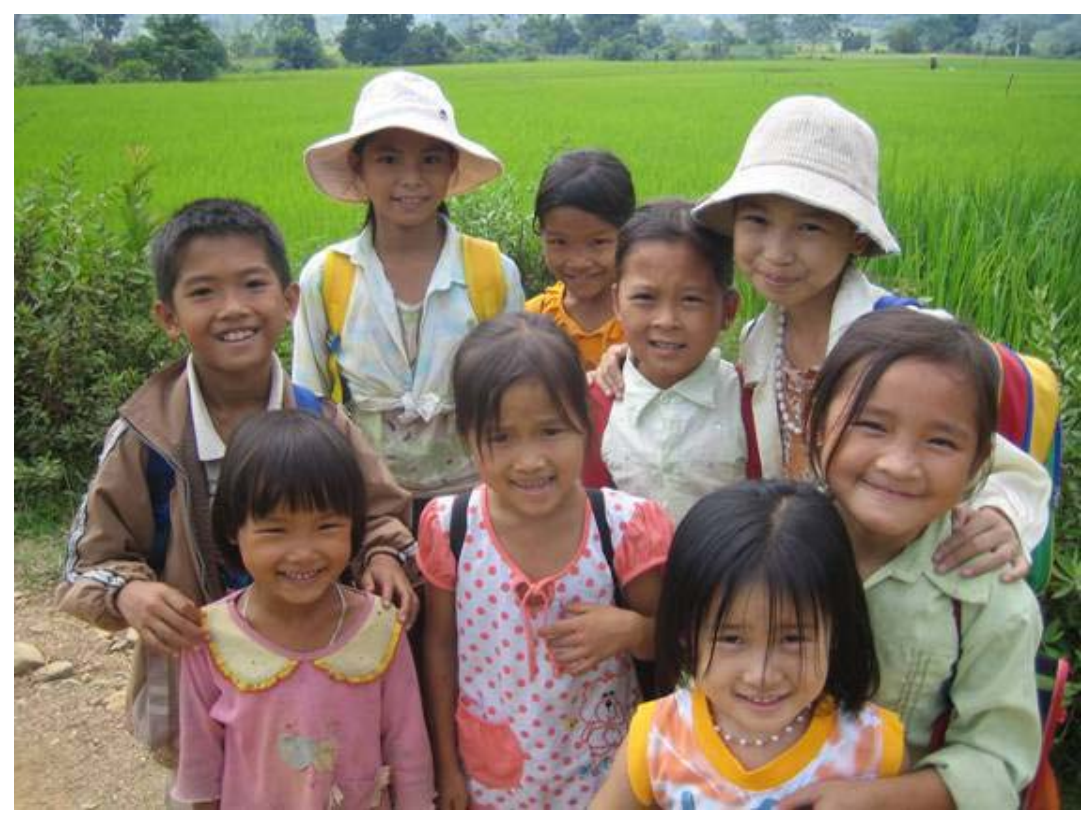

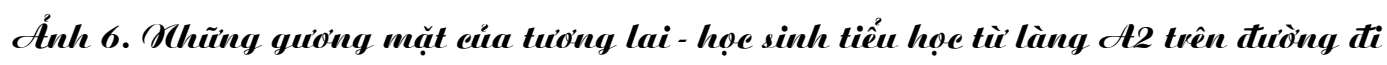

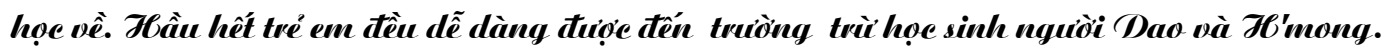

\section{Giới thiệu}

Nhiều nghiên cứu chỉ ra rằng một trong những nguyên nhân gốc rễ của việc kém phát triển đối với dân tộc thiểu số là thiếu sự chuẩn bị về giáo dục một cách đầy đủ, sự thiếu hụt này ảnh hưởng đến quá trình dịch chuyển từ tuổi niên thiếu sang tuổi thanh niên cũng như việc thụ hưởng các phúc lợi xã hội trong suốt cuộc đời họ. Mục tiêu của chương này là diễn tả quá trình tham gia học tập và quá trình chuyển tiếp từ học hành đến công việc của thanh niên, đặc biệt là thanh niên dân tộc thiểu số ở các xã miền núi phía Bắc Việt Nam. Phần đầu của chương này phân tích một cách tổng thể những dữ liệu về giáo dục ở địa điểm nghiên cứu; mô tả sự khác nhau trong việc chuẩn bị về giáo dục qua nghiên cứu thuần tập các nhóm dân tộc và cố gắng giải thích sự khác nhau đó. 
Đặc biệt, chúng tôi quan tâm giải thích những yếu tố tại sao một số học sinh vùng sâu vẫn tiếp tục đi học trong khi những đứa trẻ khác lại bỏ học. Chúng tôi cũng thực sự quan tâm đến vai trò hỗ trợ giáo dục trong chương trình giảm nghèo của Việt Nam với việc bước vào cuộc sống của thanh niên. Phần thứ hai mô tả những công việc quen thuộc khác nhau mà thanh niên vùng sâu vùng xa thường làm sau khi rời nhà trường. Chúng tôi tìm hiểu sự khác nhau trong quá trình chuyển tiếp từ việc học tập đến công việc lao động theo các nhóm dân tộc. Đầu tiên chúng tôi cố gắng tìm hiểu tại sao thanh niên chưa bao giờ rời khỏi làng của họ và những loại hình kinh tế nào sẵn sàng tiếp nhận họ. Sau đó, chúng tôi cũng cố gắng tìm các yếu tố ảnh hưởng đến quyết định của thanh niên khi di cư và cố gắng tìm hiểu những nguyên nhân nào khiến một số người lao động di cư lại thành công và mang lại lợi nhuận ở thành thị hay ở nước ngoài, trong khi một số lại thất bại. Chúng tôi cũng bàn tới tác động của chương trình giảm nghèo với thanh nhiên trong quá trình họ trở thành người tự lập về kinh tế. Chúng tôi cũng làm rõ bằng nghiên cứu với những trường hợp lao động di cư trở lại làng.

\section{Tổng quan về cung cấp giáo dục trong vùng nghiên cứu}

Tất cả các trường của huyện Võ Nhai là trường công lập, phòng giáo dục là cơ quan quản lý và cung cấp tài chính. Sơ đồ 4.2 minh hoạ cách quản lý các cấp học. Trong khi Phòng giáo dục của huyện quản lý nhà trẻ, trường tiểu học và trung học cơ sở thì 3 trường cấp III và một trường Dân tộc nội trú trung học cơ sở dưới sự quản lý trực tiếp của Sở Giáo dục - Đào tạo tỉnh Thái Nguyên.

Sơ đồ 4.2. Quản lý hành chính của trường công lập huyện Võ Nhai, tỉnh Thái Nguyên

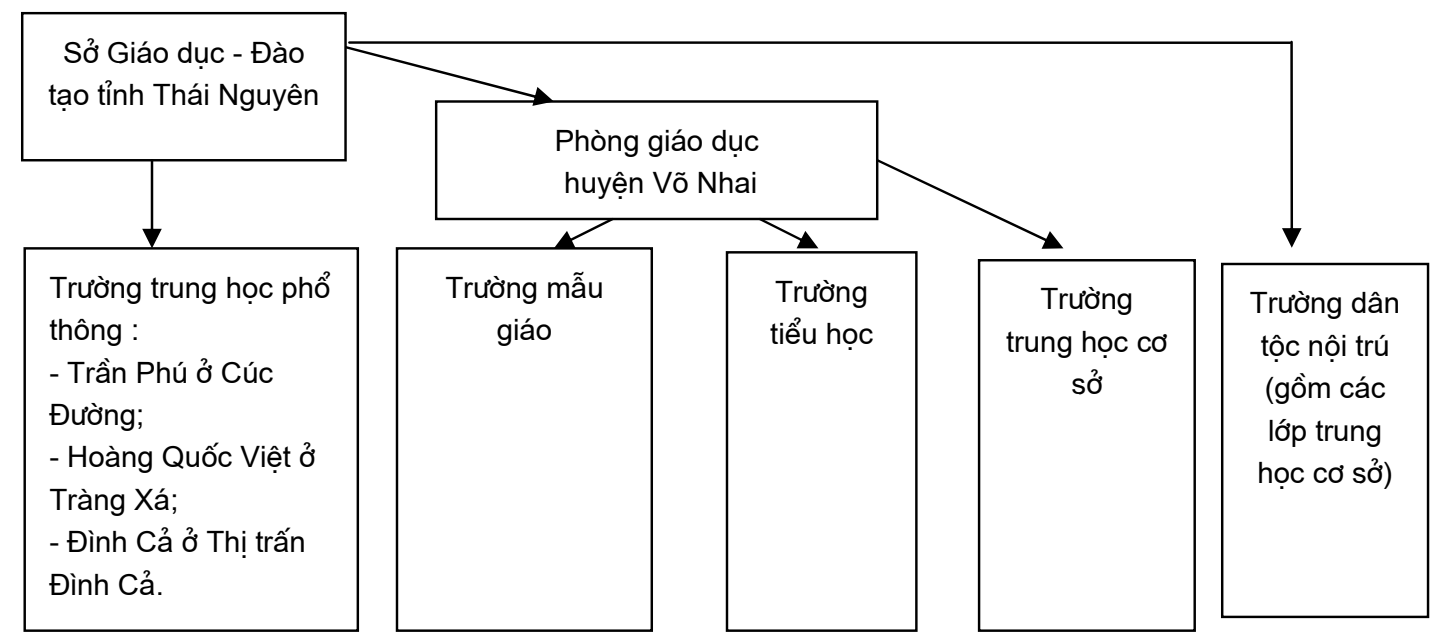

Học sinh dễ dàng được đến các lớp mẫu giáo và trường tiểu học trừ một số trẻ em người Dao và H'mong. Ở xã nhóm $\mathrm{A}$, phần lớn học sinh đến trường tiểu học và mẫu 
giáo đặt ở làng $\mathrm{A} 1$ và $\mathrm{A} 2$. Trong khi đó ở nhóm $\mathrm{B}$, trường tiểu học chính đặt ở cạnh chợ Đông Bo rất gần với làng $\mathrm{A} 1$. Các trường mới được sửa chữa và nâng cấp trong thời gian gần đây - nhóm A vào năm 2005-2006 và nhóm B vào năm 2006-2007. Hiện tại trường có hai nhà cao tầng dùng cho các phòng học và một số tiện nghi khác bao gồm văn phòng cho giáo viên, nhà vệ sinh và sân chơi. Cấp tiểu học được chia làm 5 lớp. Theo điều tra, khoảng cách trung bình đến trường cấp I gần nhất là $1,3 \mathrm{~km}$ ở người Kinh và xa nhất đến $9 \mathrm{~km}$ với người H'mong. Khoảng cách này có cao hơn chút ít so với điều tra mức sống Việt Nam (5) 1,4km ở người Kinh và $2.0 \mathrm{~km}$ ở người dân tộc thiểu số. Học sinh tiểu học tự đi bộ đến trường. Mặc dù các hộ gia đình ngày càng có nhiều xe máy nhưng cha mẹ thường không đưa con đến trường bằng phương tiện này.

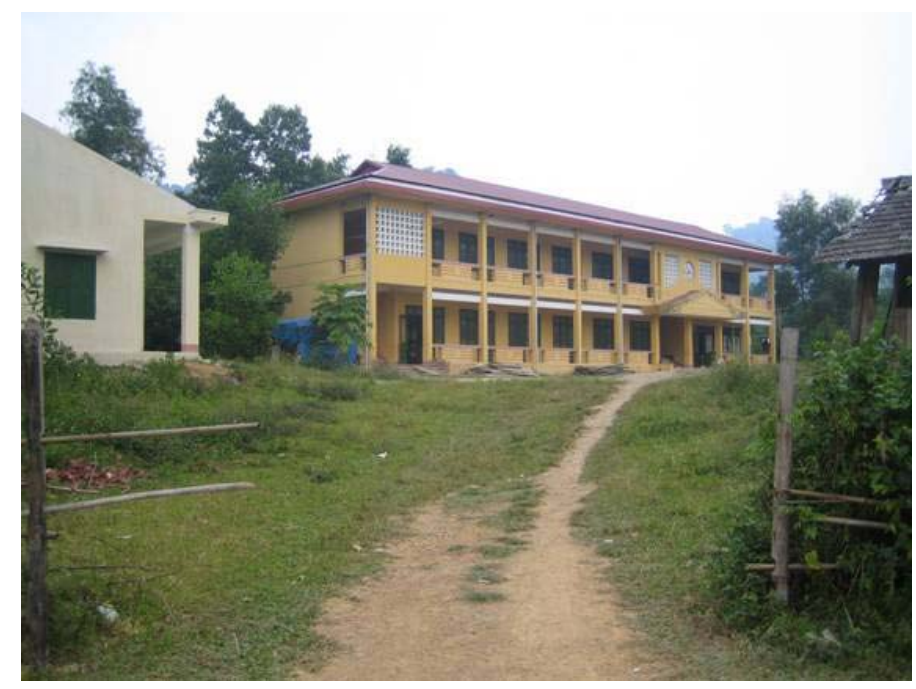

Link 7. Fruiòng tiều họe ơ uhóm $d$ cho họe sinh nguiòi Kink và Dao ở vìng này mới Tự̛ süa chüa, nâng cấp với sụ hố tợ̆ tài chính của chương trìnk 135.

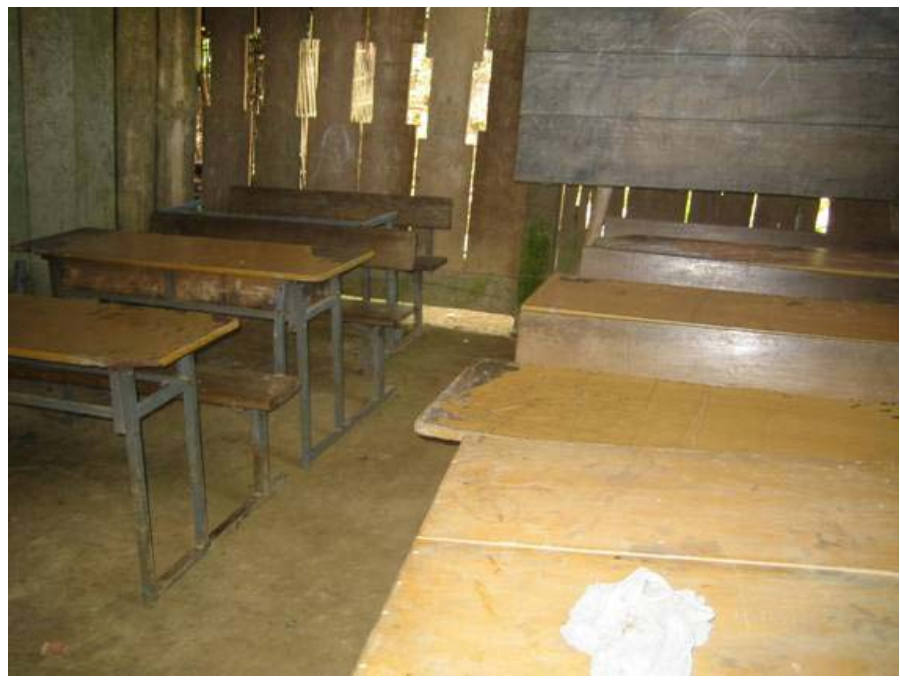

Link 8. Phân hiệu trường tiều họe ở lìng nquiòi Dao vìng xea, uhüng lớp họe chi có uhüng co sở vật chất tối thiều và cần đự̛̣e nâng cî́p. 
Không giống như phần lớn các học sinh ở đây, những đứa trẻ vùng sâu ở làng người Dao (làng A5) và làng người H'mong (làng B4) không được học ở những nơi có cơ sở vật chất và tiện nghi mới sửa chữa và nâng cấp như ở trường chính. Vì những bản làng của họ ở xa, trẻ em từ lớp 1 đến lớp 3 phải học tại bản. Học sinh người Dao ở làng A5 học tại trường phân hiệu có cơ sở vật chất thấp kém. Trường được xây ở một góc nhỏ, các lớp học có nền đất, mái lá và vài đồ dùng học tập tối thiểu. Lớp học không đủ ánh sáng, vách bằng tre, gỗ không đủ để chống chọi với thời tiết mùa đông. Những giáo viên được phân công dạy các lớp học trong làng thường không phải là người dân tộc. Họ thường sống ở nơi khác (ví dụ như trung tâm của xã) và từ đó họ thường đến lớp vào những ngày đầu tuần để dạy học rồi trở về nhà vào thứ năm hoặc thứ sáu. Trong năm học những giáo viên của trường Phương Giao được luân chuyển để dạy ở các lớp trong xã. Giáo viên miễn cưỡng nhận nhiệm vụ. Sau khi học hết lớp 3 ở trường tại bản học sinh dân tộc thiểu số phải đến trường tiểu học chính để học lớp 4, lớp 5; trường cách nhà trung bình $8 \mathrm{~km}$ đối với học sinh người Dao ở làng $\mathrm{A} 5$ và khoảng $5 \mathrm{~km}$ đối với học sinh người H'mong ở làng B4.

Từ lớp 6 đến lớp 9 (trường trung học cơ sở), học sinh nhóm $\mathrm{A}$ học ở trường Phương Giao, trung tâm của xã. Năm 2003, cơ sở vật chất của trường đã được cải tạo và xây dựng thêm, chẳng hạn như hai dãy nhà 2 tầng, phòng ăn, nơi để xe. So với trường tiểu học, học sinh nhóm $\mathrm{A}$ ít đến trường trung học cơ sở hơn vì khoảng cách và điều kiện đường xá. Theo điều tra hộ gia đình, khoảng cách trung bình là $5 \mathrm{~km}$ đối với các hộ người Kinh và $7 \mathrm{~km}$ đối với các hộ người Dao. Học sinh thường đi bộ hoặc đi xe đạp đến trường, thời gian trung bình mất khoảng 45 phút. Học sinh nhóm $\mathrm{B}$ đến trường trung học cơ sở gần hơn học sinh nhóm $\mathrm{A}$, nhất là với những học sinh ở gần chợ Đông Bo. Cơ sở vật chất của trường này được dùng chung với trường tiểu học, nên mặc dù nhà ở gần trường thuận tiện nhưng học sinh nhóm $\mathrm{B}$ luôn thiếu lớp học. Hiện tại nhà trường giải quyết vấn đề này bằng cách cho học sinh học theo ca. Ví dụ: học sinh tiểu học học buổi sáng và học sinh trung học cơ sở học buổi chiều.

Trước năm 2006, chỉ có Đình Cả là nơi để học sinh có thể học từ lớp 10 đến lớp 12 (trung học phổ thông). Trong năm 2006, trường trung học đã được xây dựng thêm ở Cúc Đường và Tràng Xá (nằm ở phía bắc huyện Võ Nhai). Tại Đình Cả, có hai trường trung học phổ thông. Trường thứ nhất tuyển những học sinh hoàn thành lớp 9 thông qua kỳ thi tuyển đầu vào. Trường thứ hai được tổ chức theo chương trình bổ túc ít có sự tuyển chọn hơn. Những học sinh học ở trường trung học phổ thông ở Đình Cả đến từ khắp nơi của huyện Võ Nhai. Họ thường ở trọ tại thị trấn Đình Cả trong những ngày phải đi học và trở về nhà vào cuối tuần (xem khung 4.1). Vào thời gian tiến hành nghiên cứu, những gia đình trong địa điểm nghiên cứu vẫn muốn gửi con ra Đình Cả học thay vì học ở trường mới xây dựng (ví dụ trường Hoàng Quốc Việt) đặt ở trung tâm của Tràng Xá. Trường trung học phổ thông Hoàng Quốc Việt hiện vẫn chưa có cơ sở vật chất riêng. Trường vẫn phải học chung địa điểm với trường trung học cơ sở. Theo những 
người dân trong làng, không có sự khác biệt về khoảng cách từ nhà (đặc biệt với nhóm B) đến hai trường trung học phổ thông Đình Cả và Hoàng Quốc Việt nhưng nhiều ý kiến cho rằng chất lượng dạy học và cơ sở vật chất ở Đình Cả tốt hơn so với Tràng Xá.

\section{Khung 4.1: Trường trung học phổ thông Đình Cả}

Vào buổi chiều muộn của ngày chủ nhật, nắng không quá chói chang và gió thổi nhẹ qua nhũng cánh đồng ngô. Thanh thiếu niên nam nữ tù xã Phương Giao đi xe đạp đến trường trên con đường đến thị trấn của huyện Võ Nhai - thị trấn Đình Cả. Với một số người, đây là khoảng thời gian để tán gẫu và cười nói vui vẻ với bạn bè. Một số khác đang gò lưng trên nhưng con đường đồi lộng gió. Những học sinh tù vùng sâu, miền núi của tỉnh Thái Nguyên mất hai giờ để đạp xe tù nhà đến chợ Đình Cả bắt đầu một tuần học mới.

Xa nhà đến học trung học phổ thông ở Đình Cả trở thành bước quan trọng cho nhiều thanh niên ở vùng nghiên cúu. Trường tiểu học và cấp trung học co sở có sã̃n ở cả hai xã. Tuy nhiên sau lớp 9 học sinh phải đến Đình Cả khoảng tù 20-25 km nếu tính tù nhóm $\mathrm{A}$. Đến tận năm 2005, Trường trung học phổ thông mới có ở thị trấn huyện. Mặc dù Nhà nước đã có những cố gắng để xây thêm trường trung học phổ thông ở xã Tràng Xá - cách xã Phương Giao khoảng 12 km, các bậc cha mẹ vẫn muốn cho con đi học ở Đình Cả, vì trường ở Tràng Xá chưa có địa điểm riêng, lớp học vẫn chung với trường trung học cơ sở và điều kiện học tập còn thiếu thốn.

Học sinh nông thôn đến Đình Cả phải đối mặt với nhũng thách thúc hàng ngày khi đây là lần đầu tiên họ xa nhà để sống ở nơi khác. " Em chưa bao giờ sống ở thị trấn mà không có gia đình. Em nhớ nhà lắm nếu mà em phải ở lại Đình Cả vài ngày. Em thích sống ở nông thôn hơn". Ly., cô gái H'mong 16 tuổi, làng B4 vừa học ở Đình Cá bắt đầu tù mùa thu vùa qua nói như thế.

Nhiều học sinh ở vùng sâu nhu Lỵ thuê nhà ở cùng với những người bạn khác. Giá thuê nhà từ khoảng 10.000 đến 20.000 đồng/người/tháng. Phòng ở rất sơ săi với những chiếc giường và đồ đạc đơn giản. Trong năm học, học sinh ở lại Đình Cả từ tối chủ nhật đến sáng thú bảy. Hồu hết trong số họ tụ dọn dẹp. nấu ăn. Để tiết kiệm tiền, những học sinh này thường mang gạo và củi tù nhà. Bố mẹ họ cho thêm một khoản tiền nhỏ để chi tiêu. "Mỗi tuần, bố em cho 15.000 đồng hoặc ít hơn. Với số tiền này em mua rau và độu phụ cả tuần. Em không thể có tiền mua thịt...". Đó là lời của Luyến, người Kinh, làng $\mathrm{A} 2$, vùa học hết trung học phổ thông năm ngoái.

Một số học sinh đỉ làm thuê ở Đình Cả để có thêm tiền chi tiêu khi hỗ trợ về tài chính và học bổng của trường không có thường xuyên. "Ngày ngày mẹ em kiếm được ít tiền nên không thể cho em tiền hàng tuần. Vì thế em phải đii 
làm ở Đình Cả sau giờ học. Những công việc này thường là công việc đơn giản. Họ thuê em làm đồng hoọ̆c những việc linh tinh...". Đây là lời của Tâm, 16 tuổi, người Kinh, làng B3, bố chết tù đầu năm 2006 để lại mẹ em trở thành trụ cột cho cả gia đình.

Sống xa gia đình, thanh niên không chỉ khó khăn để phù hợp cách sống thành thị, họ còn có những điều kiện tìm hiểu và hình thành khá năng thích úng khác với những gì họ đã tùng trải nghiệm ở nhà. Những thanh niên này cần biết quản lý tiền và thu xếp cuộc sống hàng ngày. " Em phái rất thận trọng trong chi tiêu. Mặc dù có rất nhiều quán internet, cafe hay những nơi vui chơi ở Đình Cả, chúng em không có tiền để tham gia các hoạt động này" (lời giải thích của Luyến, làng A2.)

Có nhiều học sinh đã làm tốt nhũng điều đó mặc dù không có sụ giám sát của gia đình, một số gia đình vẫn quan tâm, lo lắng về hành vi và súc khoẻ của chúng. " Có rất nhiều loại tội phạm ở đô thị. Tôi nghe nhiều chuyện về nghiện hút và có thai trước khi cưới. Chúng tôi may mắn có họ hàng ở Đình Cả. Con của tôi ở với cô ấy. Chúng tôi cảm thấy yên tâm khi có ai đó trong gia đình trông nom bọn trẻ". Một phụ nữ người Kinh có 3 con học ở trường Đình Cả nói.

Mặc dù có những thách thúc và lo lắng, nhiều người vẫn sẵn sàng đối mặt với những nguy cơ. Cha mẹ cũng như những thanh niên ở vùng sâu đặc biệt là người Kinh đã nhận thúc rõ hơn về sụ cần thiết phải có trình độ học vấn cao hơn. Nhiều gia đình đã tin tưởng giáo dục giúp họ có cơ hội kiếm sống bờng nghề phi nông nghiệp.

"Tôi không muốn những đúa con của tôi lại trở thành nông dân như tôi. Công việc đồng áng vất vả nhưng thu nhập thấp quá. Tôi muốn chúng có nghề nghiệp tốt ở thành phố. Học cao hơn là điều quan trọng để có những nghề như vậy. Dù thế nào đi nữa tôi cũng sẽ cố gắng, tôi muốn những đúa con của tôi ît nhất cũng học hết cấp III". Bà Phương, người Kinh, mẹ của 4 đúa con ở làng B1 tuyên bố.

Theo điều tra hộ gia đình, khoảng cách trung bình của hộ gia đình trong nhóm $\mathrm{B}$ đến trường trung học phổ thông gần nhất là $12 \mathrm{~km}$ ở người Kinh và $14 \mathrm{~km}$ đối với người H'mong. Học sinh nhóm $\mathrm{A}$ xa hơn khoảng 20-25 km theo cùng hướng đi đó. Phương tiện sử dụng phổ biến của học sinh ở hai xã này là xe đạp. Học sinh mất khoảng 1 tiếng từ nhóm $\mathrm{B}$ và 2 tiếng từ nhóm $\mathrm{A}$ để đến trường.

Có hai chương trình đào tạo trong hệ thống đào tạo chính quy (từ lớp 1 đến lớp 12) ở địa điểm nghiên cứu. Chương trình thứ nhất dành cho trường nội trú cấp trung học cơ sở cho học sinh dân tộc thiểu số có năng lực. Trường được đặt ở Đình Cả và được gọi 
là trường Dân tộc nội trú. Trường này thể hiện sự nỗ lực của Nhà nước để từng bước giải quyết khoảng cách về giáo dục giữa dân tộc Kinh và dân tộc thiểu số. Một trong những mục tiêu chính của trường là phải có cách giảng dạy phù hợp và đảm bảo chất lượng cao cho học sinh dân tộc thiểu số miền núi, vùng sâu có nhiều hy vọng. Học sinh vào học ở trường này dựa vào sự lựa chọn của chính quyền xã trong huyện Võ Nhai và những huyện gần đó. Về lý thuyết, sự lựa chọn này dựa vào dân tộc của học sinh (phải có cha hoặc mẹ là người dân tộc thiểu số), ở vùng sâu, có thành tích học tập tốt và cha mẹ có khó khăn về kinh tế, con em cựu chiến binh được ưu tiên. Những gia đình dân tộc thiểu số trong địa điểm nghiên cứu hy vọng con của họ có cơ hội được học ở trường Dân tộc nội trú vì chất lượng đào tạo cao hơn và chi phí được hỗ trợ nhiều hơn. Tuy thế, hiện nay rất ít học sinh dân tộc thiểu số được học ở trường này.

\section{Khung 4.2. Trường dân tộc nội trú}

Trường dân tộc nội trú được chính phủ Việt Nam thành lập trên khắp đất nước để cung cấp giáo dục trung học cơ sở có chất lượng cao cho những học sinh dân tộc thiểu số. Học phí và các chi phí khác được chính phủ hỗ trợ

Ở Đình Cả, chỉ có một trường Dân tộc nội trú thành lập giữa thập kỷ 90 cho cấp trung học cơ sở dành cho những học sinh dân tộc có khá năng học tộp của huyện Võ Nhai và những huyện lân cận *. Học sinh nhập học trường này ít nhất phái có bố hoọ̆c mẹ là người dân tộc. "Tôi thục sụ muốn cho con gái tôi đii học trường Dân tộc nội trú ở Đình Cả. Ở đó con gái tôi được giáo dục tốt và tù đó sẽ có nhiều cơ hội khác" (Vĩ, nam 29 tuổi, làng A3 có vọ lò người Nùng.)

Về lý thuyết, những học sinh dân tộc thiểu số nhập học được coi như là "những tinh hoa". Trên thực tế, mỗi Uỷ ban nhân dân xã lựa chọn một văi học sinh đủ tiêu chuẩn trong xã của họ đến trường này. Thường những cơ hội này dành cho con cựu chiến binh, đặc biệt những người tàn tật và những đúa trẻ là con cán bộ xã. Nhóm dân tộc khó khăn như Dao hay H’mong thường được lụa chọn nhiều hơn những dân tộc khác như Tày, Nùng. Những học sinh chỉ có bố hoọ̆c mẹ là dân tộc phái có điểm học cao mới được học ở trường dân tộc nội trú. "Tôi thục sụ hoài nghi về việc lựa chọn học sinh vào trường này, em gái của tôi có điểm cao nhất lớp, nộp đơn vào trường nhưng không được. Trong thôn của tôi chỉ có một học sinh được học ở đấy năm ngoái. Nó học không bằng em gái tôi nhưng ông nó là lãnh đạo ở xóm...”. Đây là lời của Xía, nữ, người H’mong, 21 tuổi, làng B4.

Việc nhập học ở trường này có sụ cạnh tranh cao, trong khi nhiều người có nhu cầu nhưng chỉ tiêu rất hạn chế nên học sinh phải được lựa chọn. Cha mẹ ở vùng nghiên cứu ca ngợi chất lượng của giáo viên trường dân tộc nội trú 
so với các trường công lập khác. Nó nằm trong chiến lược giáo dục để giải quyết nhu cầu của học sinh dân tộc thiểu số. Những học sinh được nhận vào học ở trường dân tộc nội trú ở Đình Cả dễ dàng tốt nghiệp và chuyển lên học trường Dân tộc nội trú trung học phổ thông ở thành phố Thái Nguyên. Sau đó, một tỷ lệ khá cao học sinh sẽ có thể vào những trường đại học ở Thái Nguyên hoọ̆c Hà Nội.

Lan, phụ nũ 30 tuổi, làng A2 là một ví dụ. Mẹ là người Kinh và bố là người Tày nên Lan học trường nội trú ở Đình Cả và Thái Nguyên. Sau khi học xong trung học phổ thông, cô được nhận vào học trường đại học Kỹ thuật công nghiệp ở Thái Nguyên. Sau khi tốt nghiệp, Lan đã kiếm được nghề tốt với lương cao ở một nhà máy thuộc tỉnh Sơn La. Mặc dù đã 30 tuổi những cô vẫn chưa kết hôn, Lan là niềm tụ hào của gia đình cô. "Trong tất cả những đúa con của tôi, Lan là đúa tôi có thể tụ hào vì sụ thành công của nó. Nó có nghề nghiệp tốt và luôn gửi tiền về nhà..." Ông Hoàn, 59 tuổi, bố của Lan nói.

* Hai trường Dân tộc nội trú của tỉnh Thái Nguyên đặt ở huyện Phú Lương (trường trung học cơ sở) và thành phố Thái Nguyên (trường trung học phổ thông).

Chương trình thứ hai là đào tạo cho người trưởng thành. Những lớp học đặt ở địa điểm nghiên cứu do phòng giáo dục huyện Võ Nhai quản lý. Chương trình này mang lại cơ hội cho những thanh niên bỏ học và những người trưởng thành chưa bao giờ đến trường. Những lớp học thuộc chương trình này luôn miễn phí và tổ chức vào buổi tối. Chương trình dạy người lớn tập trung vào xoá mù chữ, chủ yếu là kỹ năng đọc, viết và toán cơ bản. Mặc dù những người dân tộc thiểu số tỏ ra hăng hái khi tham dự lớp học nhưng họ vẫn cho rằng chương trình này không thực sự thành công ở địa điểm nghiên cứu vì tỷ lệ bỏ học cao. Bằng chứng là những ý kiến sau đây:

Tôi bỏ học sau khi học hết lớp 6. Tôi học kém. Cha me tôi rất nghèo. Sau đó tôi tham gia lớp học bồ túc tổ chức ở làng (làng B4). Qua chương trình này, tôi đã học xong khoá học tương đương với lớp 8 . Tôi muốn học cao hơn nhưng chỉ có vài người trong làng của tôi muốn học tiếp. Lớp 9 đã bị huỷ bỏ. Tôi đã thất vọng.

- Sài, H'mong, nam, 21 tuổi, có vợ, làng B4, nhóm B

Những ngày đâu lớp học rất đông. Có lẽ đến hơn 40 người tham dụ lớp học, nhưng nhũng ngay sau đó học sinh bắt đâu bỏ học. Một số người ở độ tuổi trung niên. Họ thường uống rượu say và không thể đến lớp học vào buổi tối. Một số thanh niên trẻ rất thích đi chơi. Đến vài ngày sau chỉ còn lại tôi cùng 2-3 người khác và cô giáo. Chúng tôi đợi những người khác đến lớp học, nhưng mà chẳng có ai cả. Lớp họ cũng đã tan.

- Xuân, Dao, nũu, 24 tuổi, mù chũ, làng A5, nhóm A 
Sau lớp 12 không có trường nào đào tạo đại học hay cao đẳng hoặc hướng nghiệp ở Võ Nhai. Thanh niên ở vùng nghiên cứu muốn học cao hơn phải đến thành phố Thái Nguyên hoặc những vùng đô thị khác. Chỉ có một số ít học sinh nhóm $\mathrm{A}$ và $\mathrm{B}$, đặc biệt là người Dao và $\mathrm{H}$ 'mong được vào học ở trường đại học hoặc cao đẳng. Phần tiếp sau sẽ mô tả sự chênh lệnh về giáo dục trong vùng nghiên cứu theo nhóm, nơi sinh, dân tộc và giới. Chúng tôi cũng so sánh sự khác nhau trong việc học tập ở những làng nghiên cứu với những quan sát ở nơi khác và cố gắng giải thích về sự thiếu công bằng này trong giáo dục.

\section{Sự khác nhau về việc học tập ở vùng nghiên cứu}

\subsection{Sự khác nhau giữa các thế hệ}

Nhìn chung thanh niên trong vùng nghiên cứu đều thích đến trường và họ được giáo dục tốt hơn thế hệ cha mẹ. Phân tích mô tả điều tra dân số làng năm 2005 đã thể hiện trong hình 4 chỉ ra xu hướng học tập theo giới và dân tộc.

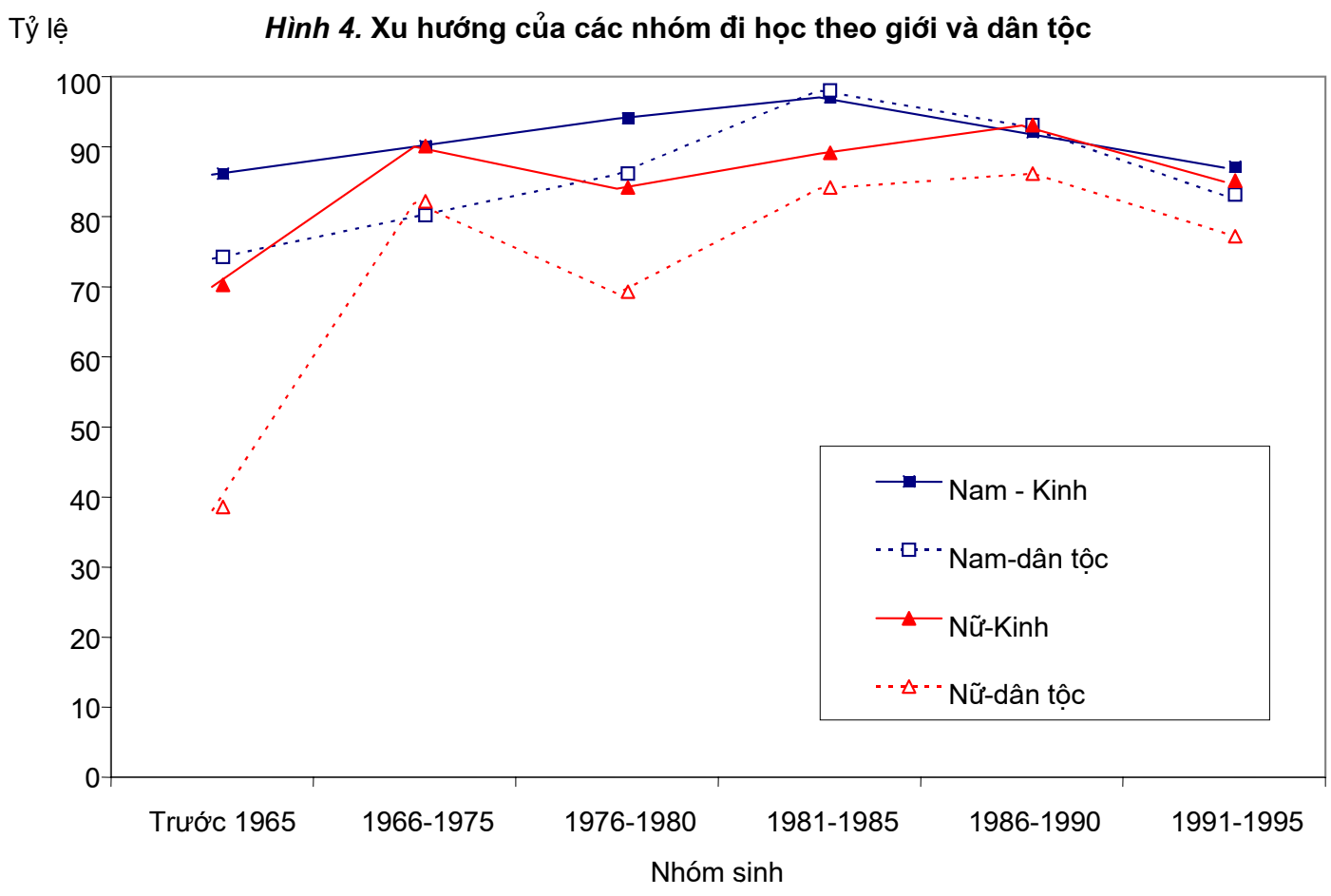

Nguồn: Điều tra dân số năm 2005 
Hình 5. Tỉ lệ những người có ít nhất học phổ thông cơ sở theo tuổi, giới và dân tộc

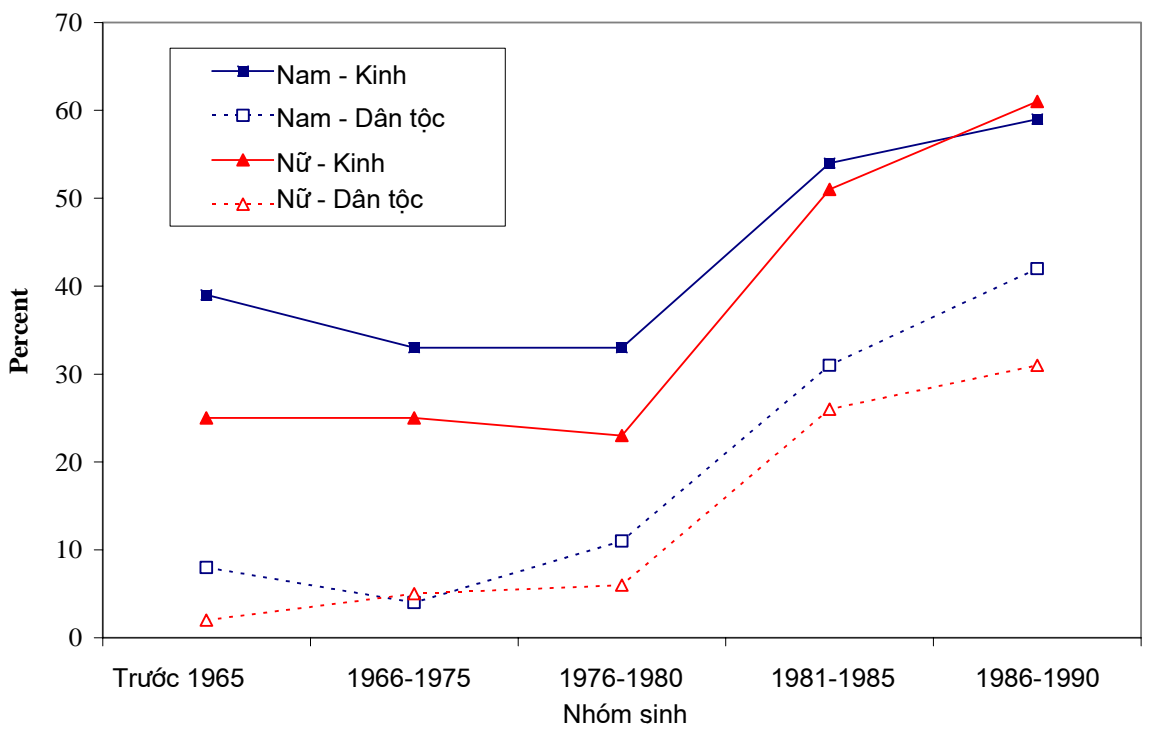

Nguồn: điều tra dân số năm 2005 Tỷ lệ (\%)

Kết quả cho thấy thế hệ thanh niên ngày nay đi học có tỷ lệ cao hơn so với những thế hệ trước. Xu hướng này đúng với cả người Kinh và người dân tộc thiểu số, cả nam và nữ. Sự khác nhau giữa các thế hệ nhiều hơn khi so sánh giữa các dân tộc. Ví dụ: hơn 40\% phụ nữ sinh trước hoặc năm 1965 (lớn hơn hoặc bằng 40 tuổi) và trên $80 \%$ phụ nữ dân tộc trẻ hơn sinh sau năm 1981 (dưới 25 tuổi) đã được đến trường ${ }^{2}$. Những phỏng vấn sâu cho thấy thế hệ cha mẹ luôn phải đối mặt với việc kiếm sống, đó là những thách thức với việc học hành của họ. Những ý kiến như sau khá phổ biến:

"Trường gần nhất là Tràng Xá. Phải mất nưa ngày để đi bộ tù̀ đây (làng A2) đến trường. Thời gian trước đây còn không có đường, chỉ có đường mòn qua rừng thôi."

- Hoan, Kinh, nam, 59 tuổi, làng A2, nhóm A

"Khi còn là học sinh tôi phải dạy tù̀ lúc 4h sáng để đến trường đúng giờ. Tôi nhớ còn phải dùng đuốc vi đường rất tối. Trường học rất xa nhà. Chỉ có vài người trẻ đi học lúc đó. Chúng tôi không có xe đạp mà phải đi bộ. Con cái chúng tôi có điều kiện tốt hơn cho việc học hành. Đường xá tốt hơn. Chúng có thể đạp xe đến trường."

- Tuyết, Kinh, nũu, 45 tuổi, làng B3, nhóm B

2Tỷ lệ chưa bao giờ đến trường của nhóm sinh năm 1976-1980 phụ nữ người Kinh và dân tộc có lẽ làm nhiễu số liệu. Chúng tôi dựa trên những báo cáo để đánh giá sự không nhất quán này. Hơn nữa, tỷ lệ nhỏ ở nhóm trẻ nhất (1991-1995) có thể được giải thích bằng việc họ đến trường muộn hơn tuổi đi học. Theo phỏng vấn sâu một số người H'mong và người Dao trẻ con bắt đầu đi học khi được 9 hoặc 10 tuổi. 
Hình 6. Tỷ lệ người dân học ít nhất hết trung học phổ thông theo nhóm, giới, dân tộc

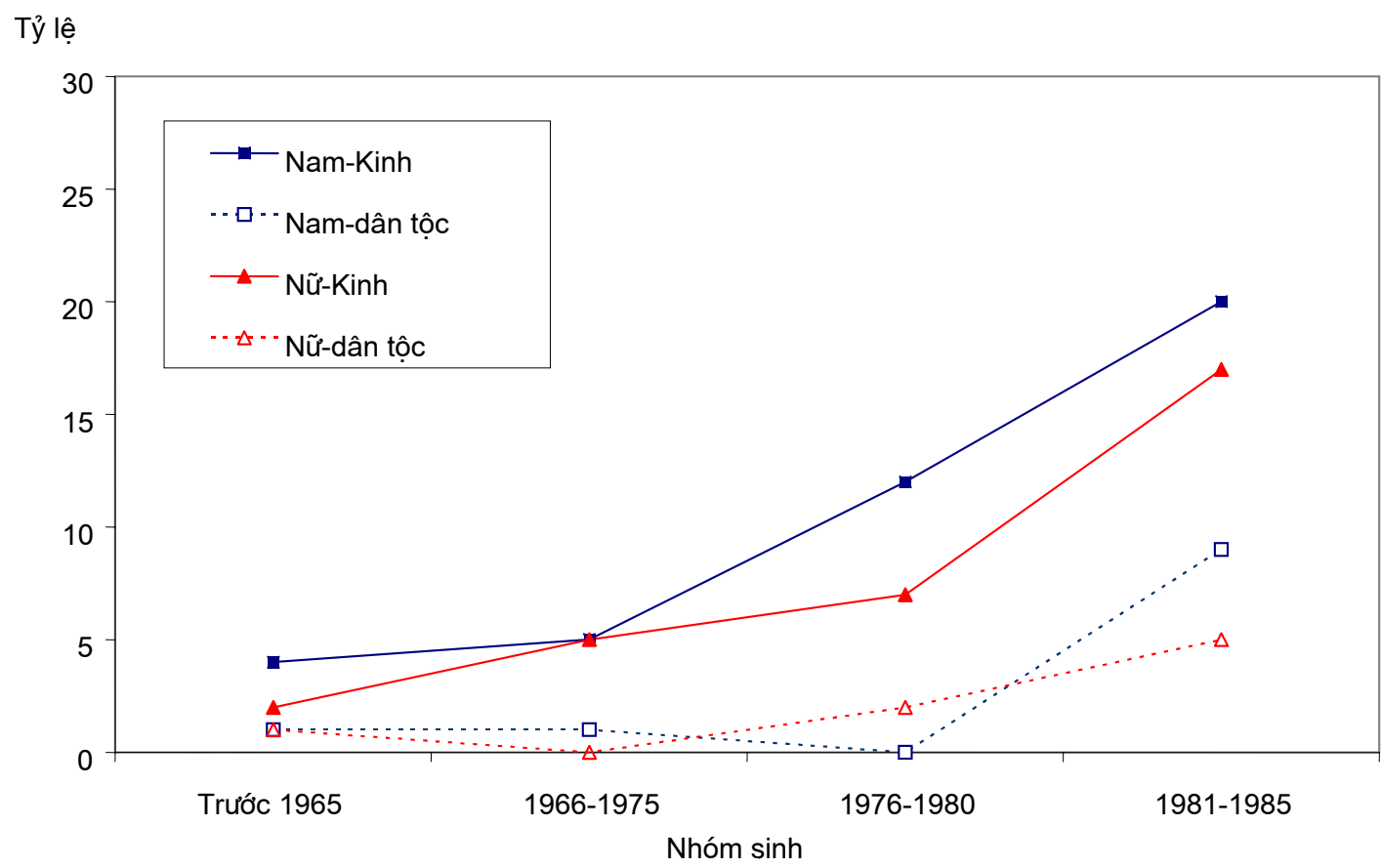

Nguồn: Điều tra dân số năm 2005

Không chỉ có sự khác nhau về tỷ lệ đến trường giữa thế hệ cha mẹ và con cái mà điều đáng chú ý là còn có sự khác nhau về trình độ của những nhóm thanh niên khác nhau. Hình 5 chỉ ra tỷ lệ những người dân đã có ít nhất trình độ phổ thông cơ sở theo tuổi, giới và dân tộc. Tỷ lệ học sinh đã học hết phổ thông cơ sở tăng lên đáng kể trong những người sinh vào các năm 1981-1985 và 1986-1990 (ví dụ những thanh niên từ 15 đến 24 tuổi). Điều này hoàn toàn đối lập với quan sát trong nhóm năm 1976-1980 (tuổi 25-29). Sự khác nhau giữa các nhóm này khẳng định sự chênh lệch giữa nhóm thanh niên người Kinh và nhóm thanh niên dân tộc thiểu số. Ngoài ra, sự khác nhau giữa các thế hệ cũng được thể hiện trong sự chuyển tiếp từ trường trung học cơ sở đến trường trung học phổ thông. Nhìn chung, tỷ lệ thanh niên học trường trung học phổ thông thấp. Đường biểu diễn học trường trung học phổ thông có xu hướng đi lên một cách rõ ràng ở những nhóm thanh niên trẻ hơn, đặc biệt nhóm sinh năm 1981-1985. Phỏng vấn một vài người dân thấy sự khác nhau trong việc tham gia học tập có thể thể hiện ngay trong các anh chị em ruột.

Đây là con đường liên xã được xây dưng mới đây. Đoàn, con trai nhỏ nhất của tôi, đã được hương lợi tù̀ con đường này nhiêu hơn anh chị nó. Nó đến trường thuận tiện hơn. Nó có thể đạp xe đến trường. Anh chị nó phải đi bộ 5-6 km để đên trường ở Phương Giao.

Bà Vang, Kinh, nũu, 49 tuổi, mẹ của 4 con, xã A2 


\subsection{Sư khác nhau về dân tộc}

Có sự thay đổi đáng kể về cơ hội học tập ở vùng nghiên cứu. Tỷ lệ đến trường tăng lên đối với tất cả các nhóm người Kinh, Dao và H’mong. Nhưng sự chênh lệnh về học tập của người dân tộc thiểu số với người Kinh vẫn được thống kê. Theo hình 4, không tính đến dân tộc, trên $80 \%$ thanh niên sinh vào năm 1980 đã đi học. So sánh nhóm nam dân tộc thiểu số và người Kinh thì không có chênh lệch về tỷ lệ đến trường nhưng tỷ lệ nữ thanh niên dân tộc thiểu số đến trường thực sự thấp hơn những nhóm khác.

Đáng quan tâm hơn là tỷ lệ học sinh dân tộc thiểu số đến trường học trung học cơ sở thấp hơn so với người Kinh. Hình 5 cho thấy nhóm học sinh nhỏ hơn đã học một số lớp trung học cơ sở có xu hướng tăng lên nhưng vẫn còn khoảng cách rất lớn. Ví dụ, trong khi gần 60\% người Kinh sinh năm 1986 đến 1990 đi học trường trung học cơ sở thì chỉ có $42 \%$ nam và $31 \%$ nữ thanh niên dân tộc thiểu số đạt được trình độ này.

Cho đến tận thời điểm hiện tại, việc học lên trung học phổ thông vẫn chưa phải là phổ biến ở địa điểm nghiên cứu. Theo giáo viên của xã Tràng Xá, dù là nơi có tỷ lệ học sinh tốt nghiệp trung học cơ sở tiếp tục học trung học phổ thông cao nhất huyện Võ Nhai, Tràng Xá cũng chỉ có $60 \%$ học sinh học trung học phổ thông trong năm học vừa qua. Việc chuyển lên trung học phổ thông là điều hiếm có đối với học sinh dân tộc thiểu số. Hình 6 chỉ ra tỷ lệ học sinh người Kinh học trung học phổ thông có xu hướng tăng lên. Ví dụ, tỷ lệ học sinh nam sinh năm 1976 đến 1980 từ 12\% tăng lên $20 \%$ so với học sinh nam sinh năm 1981 đến $1985^{3}$. Sự tăng lên này rất khiêm tốn đối với các nhóm dân tộc thiểu số, nhóm sinh năm 1981-1985 nam dân tộc thiểu số ít hơn $10 \%$ và nhóm nữ dân tộc thiểu số ít hơn thêm $5 \%$ nữa đạt được trình độ này.

"Chỉ có hai học sinh người H'mong học lớp 12. Em là một trong hai người. Thỉnh thoảng em ước trong lớp có thêm học sinh người H'mong để em có thể nói chuyện bằng tiếng H'mong. Nói được tiếng H'mong ở Đình Cả có thể làm cho cuộc sống của em dễ dàng hơn."

- Xía, H'mong, nũ, 21 tuổi, học sinh lớp 12 trường trung học phổ thông Đình Cả, nhóm B

Không chỉ có khoảng cách giữa người Kinh và người dân tộc thiểu số trong việc tham gia học tập, phân tích dân số cũng chỉ ra sự khác biệt về mức độ tham gia học tập giữa người H'mong và người Dao ở địa điểm nghiên cứu. Theo hình 7 , tỷ lệ đến trường tăng lên theo thời gian ở cả hai nhóm dân tộc. Theo các nhóm năm sinh quan sát được,

3 Hình 6 , chúng tôi không trình bày tỷ lệ nhóm sinh sau năm 1985. Học sinh miền núi luôn đi học muộn hơn tuổi đi học (6 tuổi). Vì vậy, chúng chưa hoàn thành trung học cơ sở vào thời điểm điều tra dân số tiến hành năm 2005. Sự ước lượng theo nhóm sinh có thể có nhiễu do số liệu không thực sự chính xác. 
khoảng cách về giới đến trường ở người $\mathrm{H}$ 'mong rõ rệt hơn người Dao. Tỷ lệ đến trường có xu hướng hơi đi xuống ở nhóm người H'mong trẻ nhất (nữ nhiều hơn nam). Điều này cho thấy trẻ trai và gái $\mathrm{H}^{\prime}$ mong đi học muộn hơn so với người Kinh và Dao. Học sinh người H'mong khi được 9 hoặc 10 tuổi mới bắt đầu đi học vẫn còn phổ biến. Một trong những lý do dẫn đến việc học sinh người H'mong đến trường muộn là do trở ngại về ngôn ngữ, họ giao tiếp được bằng tiếng Kinh muộn hơn so với người Dao.

Hình 7. Xu hướng các nhóm đi học theo tỷ lệ so sánh giữa người Dao và H'mong

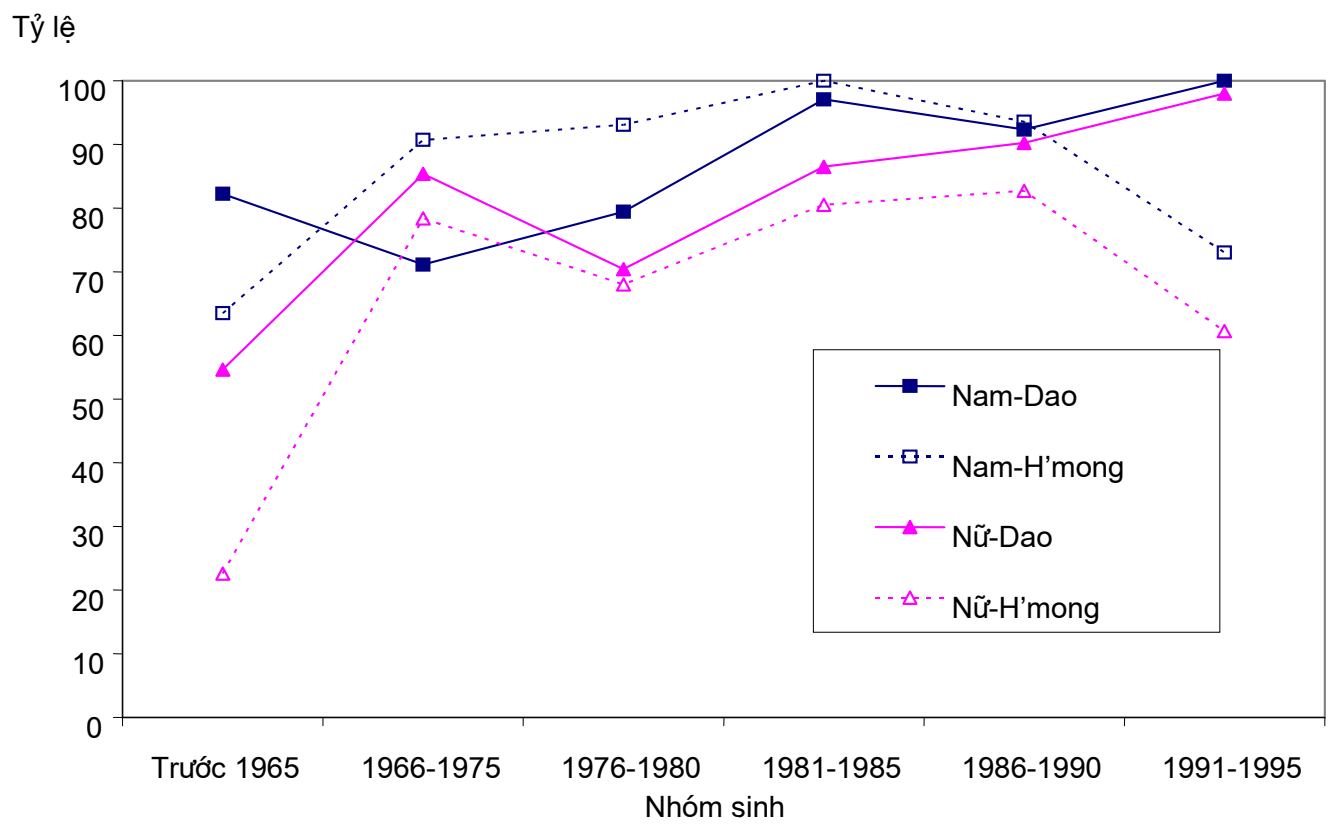

Nguồn: Điều tra dân số năm 2005

Hình 8 chỉ ra sự khác nhau giữa người Dao và H'mong trong việc học trung học cơ sở. Kết quả chỉ ra người H'mong và người Dao sinh sau năm 1980 (dưới 25 tuổi) học trung học cơ sở nhiều hơn những người sinh trước đó. Tỷ lệ học sinh người $\mathrm{H}$ 'mong và người Dao học trình độ này có xu hướng đi lên. Nữ thanh niên người H'mong có xu hướng ít học ở trình độ phổ thông cơ sở hơn so với thanh niên dân tộc thiểu số khác. 


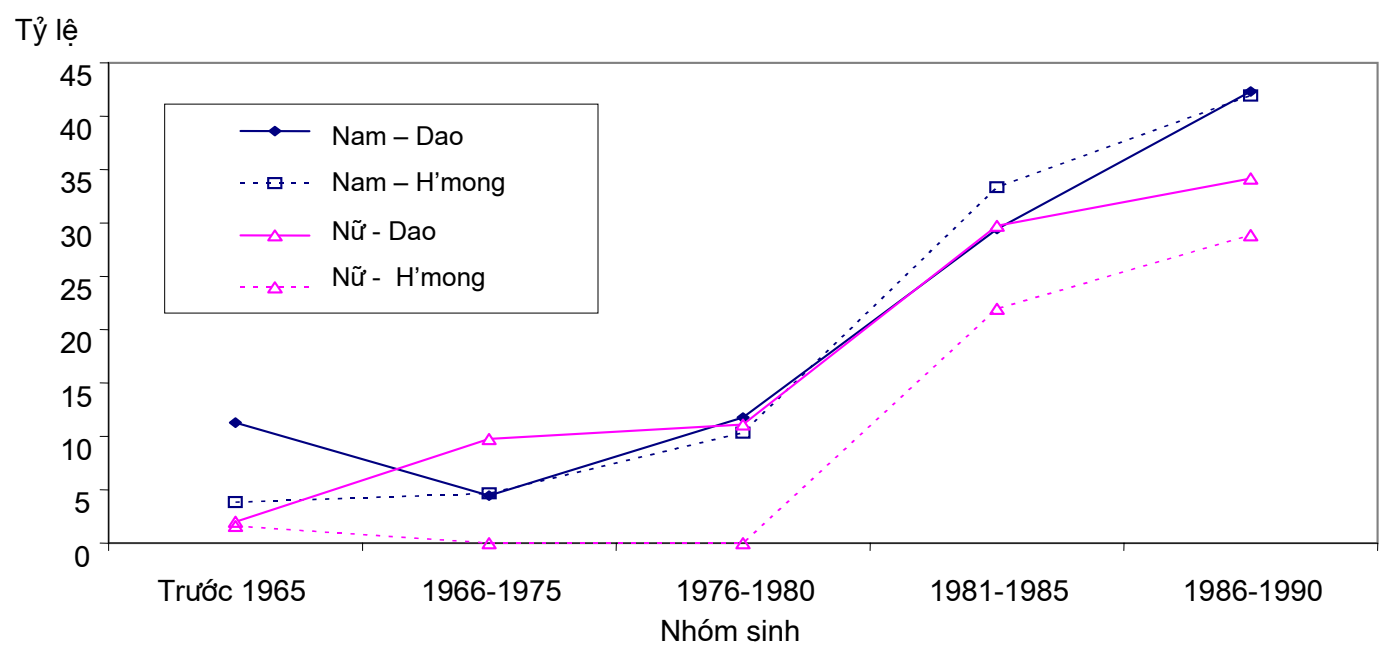

Nguồn: điều tra dân số năm 2005

\subsection{Sự khác nhau về giới}

Sự không công bằng về giới tại địa điểm nghiên cứu trong việc học tập ở người dân tộc thiểu số phổ biến hơn ở người Kinh. Ví dụ trong nhóm người dân tộc thiểu số (đặc biệt là người H'mong), khoảng cách về giới trong việc học tập thể hiện liên tục qua các trình độ khác nhau và thậm chí tồn tại trong những nhóm sinh thời gian gần đây (hình 7 và 8 ). Khoảng cách về giới của người Kinh rất hẹp qua các thời kỳ. Trong khi khoảng cách giữa nữ và nam dân tộc Kinh hẹp ở trường trung học cơ sở (hình 5), nhưng khi học lên cấp trung học phổ thông (hình 6) khoảng cách này đã rộng hơn. Ý kiến sau khá điển hình:

"Em muốn tiếp tục đi học. Bố me em nói rằng nhà mình rất nghèo, không thể cố gắng để cho em đi học được. Nhưng bố me em vấn cho em trai em đi học. Bố me em nói rằng cho con gái đi học không thực sụ cần thiết vì con gái sẽ đi lấy chông, và làm việc cho nhà chồng. Nhiều nhà trong xóm này cũng nhu nhà em. Ho không cho con gái đến trường học."

- Xuân, Dao, nũ̃, 24 tuổi, học hết lớp 2, làng A4

Sự khác nhau về giới trong việc đến trường ở vùng nghiên cứu đối nghịch với xu hướng chung của cả nước, trẻ nam và nữ có cơ hội học hành như nhau tăng lên. Việc thích con trai hơn con gái và kết hôn sớm giữa các dân tộc (sẽ thảo luận ở chương 5) gây ra sự mất công bằng về giới trong giáo dục và không thể khẳng định một cách chắc chắn điều này có thể thay đổi được trong thời gian ngắn... Đối với học sinh dân tộc 
thiểu số hoàn thành tiểu học và chuyển sang học trung học phổ thông vẫn còn là một thách thức. Đặc biệt đối với học sinh người Dao ở làng $\mathrm{A} 5$ trường học tại làng chỉ có từ lớp 1 đến lớp 3 . Đối với học sinh người Kinh ở vùng nghiên cứu, việc học từ trung học phổ thông lên học cao đẳng hay đại học vẫn còn có nhiều khó khăn. Tràng Xá là một ví dụ, rất ít học sinh học xong trung học phổ thông thành công khi thi vào trường đại học hoặc cao đẳng. Năm 2005 chỉ có một học sinh xã này đỗ đại học. Năm 2006 tăng lên 7 học sinh - một tỷ lệ nhỏ so với số lượng tốt nghiệp trung học phổ thông. Hầu hết các học sinh của huyện Võ Nhai không tiếp tục học sau lớp 12. Với những học sinh cố gắng học tập, họ thường chỉ học các trường cao đẳng. Những số liệu về tỷ lệ chuyển lên học cấp cao hơn còn ít cho thấy cần chú ý nhiều hơn đến chất lượng dạy và học; đồng thời phải có những cố gắng để giữ học sinh tiếp tục đến trường trong vùng nghiên cứu.

\section{Giải thích nguyên nhân sự khác nhau trong việc học tập}

Có rất nhiều nguyên nhân giải thích tại sao thanh niên ở vùng nghiên cứu không theo kịp những thanh niên Việt Nam nói chung trong quá trình học tập và tại sao thanh niên dân tộc thiểu số kém phát triển nhất. Phân tích trình bày trong phần này sử dụng kết quả quan sát có sự tham gia và phỏng vấn sâu thanh niên từ 15 đến 29 tuổi và cha mẹ của họ. Chúng tôi cũng sử dụng đánh giá nhanh cộng đồng, các giáo viên trong địa điểm nghiên cứu được phỏng vấn.

\subsection{Khả năng tiếp cận giáo dục}

Ở vùng sâu đâu là lý do trực tiếp làm cho thanh niên bỏ học hoặc không tiếp tục đến trường sau khi đã kết thúc năm học? Nhìn chung, nhiều gia đình vẫn muốn để con cái học lên trung học nhưng khó khăn trong việc đi lại đến trường trung học là cản trở chính: chỉ có một trường trung học cơ sở đặt ở trung tâm xã Phương Giao; khi học lên trung học phổ thông học sinh không có lựa chọn nào khác ngoài trường trung học phổ thông Đình $\mathrm{Ca}^{4}$. Trong vài năm vừa qua, ở địa phương đã có nhiều nỗ lực nhằm giảm bớt khó khăn cho học sinh đến trường bằng cách cải tạo lại con đường liên xóm và cơ sở vật chất của trường học. Trên thực tế chỉ có những học sinh dưới 15 tuổi mới nhận được lợi ích từ những con đường liên xã, liên xóm mới được xây dựng vào năm 2000. Chỉ có một ít người được phỏng vấn (15 đến 29 tuổi) nói việc học tập của họ được thuận lợi nhờ những con đường mới xây dựng.

Khi em còn đi học cấp I và cấp II, đi đến trường rất khó khăn. Khi học lớp 6, em phải đi bộ tù đây đến trung tâm của xãa. Em nhớ là mất nhiều thời gian. Khi đó

4 Trường trung học phổ thông ở Tràng Xá được thành lập năm 2006. Vào thời điểm nghiên cứu quá sớm để đánh giá tác động của trường học này đối với việc thanh niên tham gia học trung học phổ thông. 
đường không tốt như bây giờ. Đến tận năm 2003-2004 đường mới được xây dụng. Vì vậy em đã không được hưởng lợi tù̀ con đường này phục vụ cho việc học hành.

- Khải, Tày, nam, 25 tuổi, làng Al, nhóm A

Nhà của chúng tôi rất xa trung tâm làng. Trước đây phải mất khoảng 3 giờ để đi đến trường học. Bây giờ con đường đã tốt hơn trước đôi chút, mất khoảng 1 tiếng rưỡi đi bộ đến trường tiểu học Phương Giao. Tuy vậy nhuing con tôi vẫn phàn nàn rằng nó cảm thấy mệt khi đi đến trường vì xa quá. Nó quyết định bỏ học khi hoc hết lớp 7.

- Khanh, Dao, nũu, 52 tuổi, làng A5 (làng xa nhất)

Hiện tại khả năng có được cuộc sống bình thường vẫn là những khó khăn đối với học sinh người Dao ở làng $\mathrm{A} 5$ và H'mong ở làng xa nhất $\mathrm{B} 4$. Chúng còn khó khăn hơn bởi các nguyên nhân khác như cơ sở vật chất của trường học và chương trình học không phù hợp với nhu cầu của học sinh. Ví dụ, vì thiếu lớp học nên nhiều học sinh phải học vào buổi chiều (có những lớp khác học vào buổi sáng) và tan học khi chiều muộn. Một số học sinh Dao và H'mong không thể về nhà trước trước 7 hoặc 8 giờ tối vì họ phải tiếp tục đi con đường qua núi rất xa. Trong khi đường xá đi lại đã khó khăn, một số gia đình còn lo lắng đến sự an toàn của con cái họ đặc biệt là những bé gái.

Trường rất xa nhà. Nó đặt ở Phương Giao. Khi con gái tôi đi học, nó không thể trở về nhà trước khi trời tối. Một tối nó gặp người đàn ông say rượu. Ông ấy đã bắt lấy nó và đánh đập nó. May mắn là nó đã trốn thoát. Nó rất hoảng sợ. Sau tai nạn đó nó quyết định bỏ học...Mặc dù có 4-5 học sinh khác học cùng trường nhưng khác lớp con gái tôi vẫn sợ đi 7-8 km trời tối.

- Lưu, Dao, nũu, 44 tuổi, làng A5

\subsection{Sư thiếu thốn về kinh tế}

Ngoài khả năng chưa có được những điều kiện đi lại bình thường, sự nghèo đói của gia đình là nguyên nhân khác ảnh hưởng đến việc học tập của người dân ở địa điểm nghiên cứu. Trước thời kỳ đổi mới, khi đồng tiền kiếm được rất hiếm, học phí được đóng bằng ngô. Vào những năm 1980, một gia đình cho con đi học chỉ phải nộp $30 \mathrm{~kg}$ ngô cho một học kỳ. Tương tự như thế, lương của giáo viên cũng được trả bằng ngô, hoặc gạo, một giáo viên đã nhớ lại anh ta nhận được 30 kg gạo 1 tháng (vì lương thấp nên sau đó anh ta đã bỏ nghề). Những năm ngay sau đổi mới cha mẹ phải đóng học phí cho con bằng tiền mặt. Từ những năm 1990 khi cả Phương Giao và Tràng Xá được xếp vào loại khó khăn nhất, được hưởng chương trình 135 và chương trình xoá đói giảm nghèo, những hộ gia đình có con đang ở độ tuổi đi học được sự hỗ trợ cho việc học tập. Không tính đến tình trạng kinh tế hộ gia đình hay dân tộc, học sinh từ lớp 1 đến lớp 12 đều không phải đóng học phí. So với học sinh người Kinh, học sinh dân tộc thiểu số được sự hỗ trợ cho học tập nhiều hơn chút ít. Ví dụ, bắt đầu năm 2006, họ 
nhận được 60 ngàn đồng để mua sách vở trong một năm học. Hơn nữa họ cũng được giảm những đóng góp ở trường học như quỹ xây dựng cơ sở vật chất.

Mặc dù thu nhập đã tăng lên và có nhiều hình thức hỗ trợ khác nhau cho giáo dục trong vài năm vừa qua, sự thiếu thốn về kinh tế vẫn là những lý do chính giải thích tại sao tỷ lệ học sinh đến trường trung học vẫn còn thấp và chỉ có một số ít học sinh thành công trong việc học cao hơn. Trong khi học phí và một số loại phí được miễn, các gia đình vẫn phải nộp những chi phí khác cho những đứa trẻ đi học. Chi phí phải đóng góp bao gồm cơ sở vật chất, thuốc men, vệ sinh, trông xe, nước uống, lễ tốt nghiệp... Trong khi phỏng vấn người dân luôn bày tỏ những thắc mắc về các khoản đóng góp đó. Có sự không thống nhất làm người dân thắc mắc, thường là: cái đó giá bao nhiêu và họ thực tế được hưởng bao nhiêu. Theo hiệu trưởng trường tiểu học Phương Giao, về lý thuyết cha mẹ phải nộp cho một học sinh 70.000 đồng một năm. Nhưng khi phỏng vấn, học sinh và cha mẹ họ đều nói rằng họ phải nộp nhiều hơn mặc dù đã được miễn học phí và vài loại đóng góp khác.

Tôi nghĩ bên cạnh học phí, những gia đình ở vùng xa nên được miến các phí khác nhu cơ sở vật chất hay sách giáo khoa. Những phí này có thể nhỏ, nó có thể không đáng gì so với những gia đình ở thành phố nhưng đối với những người sống ở đây thì đó là khoản tiền rất lớn.

- Cẩm, dân tộc Nùng, nũu, 50 tuổi, làng Al, nhóm A

Nhiều gia đình ở vùng nghiên cứu không thể cố gắng cho con đi học trường trung học phổ thông ở Đình Cả. Việc học đại học hoặc cao đẳng được xem như là không thể đối với hầu hết các hộ gia đình. Những khoản tiền phải chi không chỉ là học phí ở những cấp học này cao hơn mà còn là chi phí về chỗ ở và ăn uống hàng tháng. Những chi phí này học sinh miền núi không được Nhà nước hỗ trợ (xem khung 4.1). Mặc dù có nhiều sự hỗ trợ khác nhau cho học tập, một học sinh người Dao làng $\mathrm{A} 2$ bắt đầu năm đầu tiên ở trường trung học phổ thông Đình Cả nói gia đình cô phải mất 500.000 đồng cho một năm học. Trong khi đó một người phụ nữ Kinh cùng làng với cô nói rằng con của cô ta học ở Đình Cả phải mất 1 triệu đồng cho một năm. Cả hai người phụ nữ này nói ở thị trấn Đình Cả mặc dù con của họ đã phải sống rất thiếu thốn. Để có được khoản tiền mặt cho con đi học cao hơn, một số gia đình người Kinh đã bán tài sản của họ như đất đai hay trâu bò. Những gia đình dân tộc thiểu số không thể làm như vậy bởi tài sản của họ rất ít.

Một người bác của em đã bán 3 mảnh đất được tất cả 33 triệu đông nên bác ây có thể gưi con đi học dại học ở Thái Nguyên. Bây giờ bác ây cũng mua cả xe máy cho con trai.

- Vĩnh, Kinh, nam, 23 tuổi, học hết lớp 9, làng B3, nhóm B

Em thật sụ hy vọng rằng trường học sẽ nhận được các chính sách liên quan đến hỗ trợ tài chính cho học sinh. Nhiều gia đình ở đây không thể cố gắng cho con họ 
đến trường. Những học sinh này phải bỏ học. Ví dụ, em có 5-6 anh chị em đang học trung học. Mặc dù tiên học phí đã được miến, bố me vẫn phải nộp 120.000 đồng cho mỗi đứa một năm cho những chi phí khác. Điều đó có nghĩa là mỗi năm nhà em phải trả trên một triệu đông. Làm thế nào để nhà em có được khoản tiên đó? Nhà em chỉ có một con trâu và đấy là của cải đáng giá nhất. Nhà em không thể bán trâu để trả tiền cho anh chị em đi học. Nếu nhà em bán trâu thì chẳng có gì để cày ruộng.

- Tài, Dao, nam, 27 tuổi, làng Al, nhóm A

Trong khi những hỗ trợ về tài chính đang khuyến khích cha mẹ cho con đến trường thời gian dài hơn nhưng do nhiều gia đình vẫn đứng bên bờ vực của nghèo đói nên việc cho con nghỉ học vẫn là hiện tượng phổ biến nhất là khi phải trải qua những "cú sốc" về kinh tế. Những phúc lợi xã hội khác tốt hơn có thể có tác dụng khuyến khích trẻ đến trường giống như được miễn học phí.

Khi mà bố em bi ốm, bố mẹ em nói anh cả bỏ học và đi làm. Khi đó anh ấy đang học lớp 9. Đầu tiên anh ây không nghe lời bố mẹ. Anh ây nói với bố me em là phải đi học để kiếm được việc làm có thu nhập cao. Anh ây nghĩ rằng chỉ với trình độ cấp II anh ấy không thể kiếm được việc làm tốt. Cuối cùng anh ấy cũng đã phải nghỉ học. Bố em bị ốm nên gia đình em không thể có tiền cho anh ấy đi học được nũa.

- Hoa, Kinh, nũ, 19 tuổi, học hết lớp 5, làng A3

Hơn nữa, kinh tế hộ gia đình cũng bộc lộ nhu cầu lao động trẻ em và làm ảnh hưởng đến việc học hành của chúng. Trước đây những đứa trẻ lớn không được đến trường phải ở nhà để trông em, như thế cha mẹ chúng mới có đủ thời gian để làm ruộng. Thế hệ thanh niên lớn lên với 5-6 anh chị em là rất phổ biến. Những chuyện như thế này ít xảy ra hơn đối với thiếu niên nhất là đối với người Kinh. Khi các hộ gia đình ở huyện Võ Nhai cố gắng gia nhập nền kinh tế thị trường nhu cầu đầu ra cho nông nghiệp cao hơn, nói chung yêu cầu lao động trẻ em sản xuất tại hộ gia đình giảm xuống. Hai lý do quan trọng để yêu cầu về lao động trẻ em giảm là tỷ lệ sinh giảm đáng kể và nhận thức đúng đắn hơn về giá trị của học vấn.

\section{3. Động cơ và sự nhiệt tình đối với học hành}

Hoàn toàn phù hợp với những nghiên cứu khác, chúng tôi thấy thanh niên ở vùng nghiên cứu hiện nay nhiệt tình hơn với việc học tập và kết quả học tập có tiến bộ hơn (bao gồm cả việc đến trường và thái độ chăm chỉ trong học tập) hơn những thanh niên trước đây. Sự khác nhau về thái độ của thanh niên ở đây với kiến thức có thể được giải thích bởi rất nhiều các yếu tố khác nhau bao gồm nhận thức về giá trị của học tập, cha mẹ tham gia vào dạy con cái, chất lượng của giáo dục và ảnh hưởng của bạn bè. Người dân đã nhận thấy giá trị của học hành (cả trẻ và già). Tuy nhiên, nhận thức về giá trị học vấn của thanh niên các nhóm khác nhau là không giống nhau. Hầu hết thanh niên người 
Kinh nhận thấy học tập giúp cho người ta làm kinh tế tốt hơn, thanh niên dân tộc thiểu số nhìn thấy lợi ích học hành trực tiếp liên quan đến việc buôn bán các sản phẩm nông nghiệp. Ví dụ, một người thanh niên dân tộc H'mong nói rằng nhờ học hành anh ta đã thoát khỏi cảnh mù chữ và anh ta biết làm các phép tính. Trong khi người xu hướng của người Kinh mong muốn có học vấn cao hơn để thoát khỏi cảnh lao động nông nghiệp, đặc biệt lao động thuần nông.

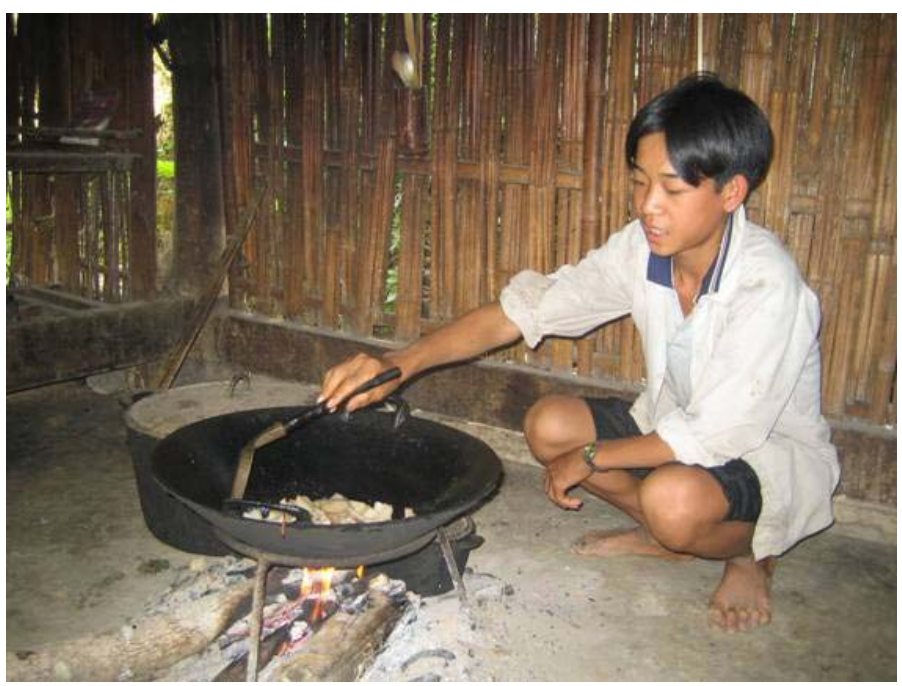

Link 9. Mam thank niên 17 tuổi không còn tiếp tục đến truiòngy.

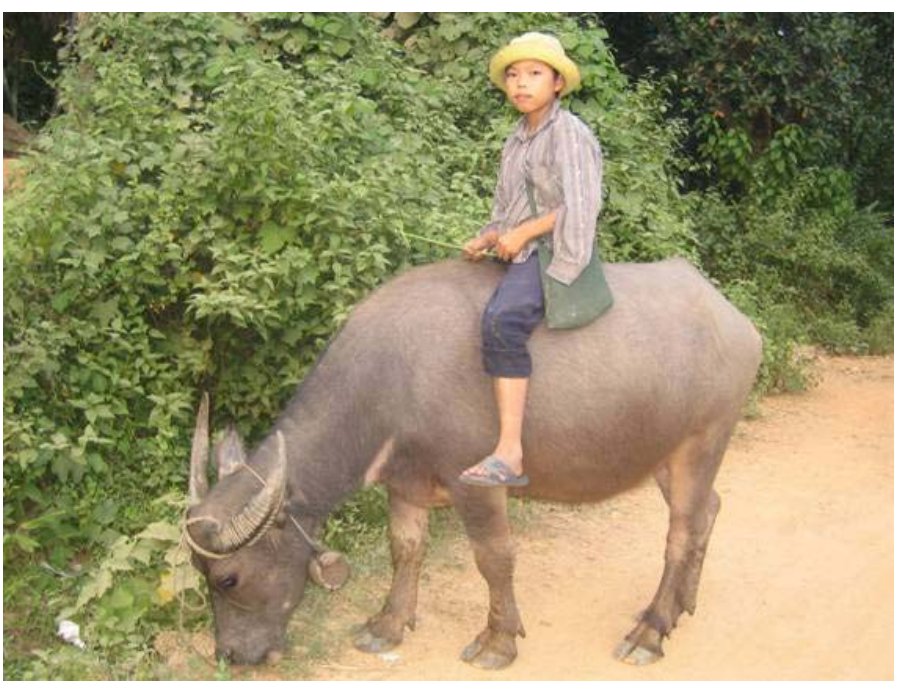

Cinh 10. Trué chăn trâu làng A2, trâu vấn là công cụ chư yếu đề cày vaộng. ZOộ gia đinh vî̃n cần lao động tré em tham qia vào cáe hoụt đṭ̂ng sain xuất

Mặc dù việc học tập có giá trị cao đối với thanh niên không kể đến dân tộc hay tình trạng kinh tế nhưng rất khó để mọi người vượt qua những khó khăn để học tập. Ví dụ, những trường hợp nhà quá xa trường, sự mệt mỏi để đến trường hàng ngày làm cho họ khó có thể ham thích đi học. Hơn nữa, thanh niên trong làng nghiên cứu luôn phải 
làm thêm công việc đồng áng hoặc việc nhà khi họ còn đi học. Bố mẹ thường phân nhiều việc khác nhau cho trẻ khi chúng 6 hoặc 7 tuổi. Một đứa trẻ 11 tuổi người Kinh may mắn trong gia đình ở làng $\mathrm{A} 2$ kể về cuộc sống hàng ngày như sau:

"Cháu thường dạy trước 5 h sáng. Cháu giúp mẹ cháu làm đậu phu và chuẩn bi cám chăn lợn. Sau đó cháu chuẩn bị đến trường. Cháu thường ra khỏi nhà lúc $6 h 30$ sáng. Trường cách nhà cháu $5 \mathrm{~km}$. Cháu thường ở trường đến tận trưa. Sau đó cháu trở về nhà, thường là $1 \mathrm{~h}$ chiều. Cháu giúp mẹ cháu bán đậu phụ ở gần làng hoạc thỉnh thoảng cháu trông em. Đến 4 h chiều cháu đi chăn trâu. Sau đó cháu mới có thời gian để học bài."

Những đứa trẻ sống trong những hộ nghèo luôn phải làm việc nhà và công việc đồng áng nhiều hơn là được sự chăm sóc của gia đình. Rất nhiều thanh niên khi chúng tôi phỏng vấn phàn nàn rằng những công việc làm cho gia đình thỉnh thoảng khiến chúng quá mệt mỏi không thể học bài buổi tối mặc dù vẫn muốn học tập.

"Khi đang đi học, em phải chăn trâu và trông em trai, em gái. Em cảm thấy mệt mỏi sau khi làm việc cả buổi chiều. Em không thể ngủ ngon, em luôn không hiểu bài cô giáo giảng nhũ̃ng ngày tiếp theo."

- Sài, H'mong, nam, 24 tuổi, học hết lớp 8, làng B4, nhóm B

Nhu cầu lao động trẻ em là một yếu tố quan trọng làm giảm lòng ham thích học tập của thanh niên trong vùng nghiên cứu. Để tiếp tục đến trường hoặc để chuyển lên cấp học cao hơn, họ thiếu những hình mẫu để noi theo. Ý kiến sau đây rất điển hình:

Em không có tấm gương nào cả. Nhũng người trong làng này cũng nhu em thôi. Em không biết ai có trình độ học vấn cao hay có nghề nghiệp tốt ở ngoài làng.

- Thanh, Dao, nũ, 29 tuổi, làng A5

Nhiều người nhiều tuổi hơn, cả người Kinh và người dân tộc học hết trung học phổ thông hoặc cao đẳng rồi lại trở về nhà vì họ không thể tìm được việc làm. Tỷ lệ thất nghiệp cao ở ngành phi nông nghiệp làm giảm nhiệt tình học tập của thế hệ trẻ. Đây là tiếng nói của một nam thanh niên người H'mong học lớp 10 trong lần đi phỏng vấn đầu tiên và đến lần phỏng vấn thứ hai anh này đã bỏ học.

Em không biết nếu em đi học lâu hơn thậm chí là khi em học hết lớp 12, em có thể kiếm việc làm không? Em nhìn thấy rất nhiều ví dụ trong làng của em. Họ đã đi học ở Đình Cả nhưng lại trở về nhà để làm ruộng. Họ không thể kiếm được việc làm.

- Mái, H’mong, nam, 20 tuổi, làng B4, nhóm B

Hầu hết thanh niên nói họ luôn nghĩ đến việc nghỉ học. Bằng chứng cho thấy yếu tố gia đình có tác động mạnh mẽ đến động cơ của bọn trẻ tiếp tục đi học hay quay trở về hoặc tác động đến sự thành công trong học tập của họ.

Em đã nghĩ đến chuyện bỏ học mâyy lần. Nhưng thực tế em đã bỏ học một tuần hồi em học lớp 10. Em thấy bố mẹ làm việc rất vất vả để cho em và 4 anh chị em khác 
đi học. Em cảm thấy rất buồn cho họ. Bố mẹ nài nỉ em đến trường. Họ nói rằng ho sẵn sàng làm việc vất vả vì vâyy ho nỗ lực để chi trả cho các chi phí trong trường học. Họ thực sư quan tâm đến việc học tập của bọn em. Em cố gắng học tốt nhất. Em đã học hết lớp 12.

- Xuân, Dao, nũu, 26 tuổi, làng Al, nhóm A

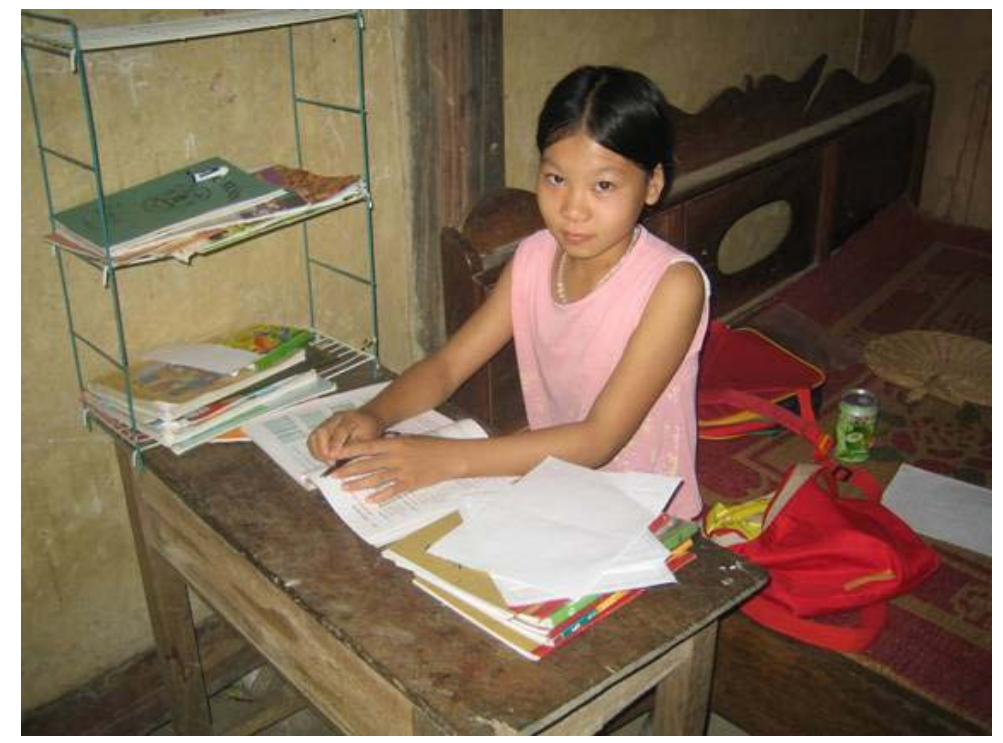

dunk 11. Bé qái người Kink này vất may mắn có góe họe tập ở whà. Dhiều túka tré trong làng nghiên cứu phải làm việe nhà và đồng áng sau qiờ họe.

Cha mẹ người Kinh trong vùng nghiên cứu quan tâm đến việc học hành của trẻ nhiều hơn cha mẹ người dân tộc thiểu số. Các giáo viên cũng đã nhận xét một số cha mẹ dân tộc thiểu số thường không đi họp phụ huynh học sinh. Sự khác nhau về mối quan tâm này có thể giải thích bởi trình độ học vấn của cha mẹ, điều kiện xã hội và nhận thức về giá trị của việc học tập. Sau đây là những ý kiến khác nhau của cha mẹ người Kinh, Dao, H’mong phản ánh tầm nhìn khác nhau của họ về việc học hành của con cái.

Sự quan tâm của cha mẹ đối với việc học hành ảnh hưởng đến sụ thành công trong học hành của con cái. Cha me không thể thờ ơ trước việc học hành của con cái. Tôi quan tâm đến nhũng thông báo của nhà trường. Tôi luôn mong muốn gặp các cô giáo của con tôi. Ví du đứa con nhỏ nhất của tôi học lớp 6. Thậm chí tôi biết cháu là đứa học xuất sắc. Tôi vẫn cùng với cô giáo kiểm tra xem cháu học hành thế nào, đặc biệt xem môn học nào cháu học xuất sắc ở trường. Vì vây tôi biết giúp đỡ cháu học đúng cách.

- Vô, Kinh, nam, 42 tuổi, làng B1, nhà giàu có một con trai học hết lớp 12 và một con trai khác dang học tiếng Đức ở một trường Đại học ở Hà Nội. 
Con trai của tôi học hết lớp 9. Tôi không khuyến khích cháu tiếp tục đi học. Tôi muốn cháu ở nhà giúp tôi làm việc. Ở trường, nó chỉ học vẹt. Trường học không dạy chúng trở thành người đàn ông tốt.

- Cao, H'mong, nam, 55 tuổi, nông dân, làng B4

Tôi đồng ý kiến thức là quan trọng. Nhưng nếu chúng tôi không có tiền con trai chúng tôi phải bỏ học. Nó phải chấp nhận điều đó. Tôi không có ý định vay tiên cho con trai tôi đi học.

- Tiên, Dao, nam, nông dân, làng Al

Không chỉ sự quan tâm của cha mẹ ảnh hưởng đến nhiệt tình của bọn trẻ trong việc đi học mà bạn bè cũng đóng vai trò quan trọng trong việc xác định mục đích học tập. Trong khi làm việc tại địa bàn nghiên cứu, chúng tôi đã gặp gỡ nhiều thanh niên, đặc biệt là thanh niên dân tộc thiểu số do ảnh hưởng của bạn bè mà bỏ học. Ví dụ, Hà là người Dao 16 tuổi ở làng $\mathrm{A} 5$ đã nói bạn cô có 9 học sinh học lớp 5 . Họ thường cùng đến trường và cùng đi chơi. Cuối năm học, 1 học sinh bỏ học thì 5 học sinh khác gồm cả Hà cũng bỏ học theo. Năm học sau đó có 3 học sinh của làng cô học lớp 6 . Theo Hà lòng ham học của cô bị giảm xuống khi bạn của cô bỏ học. Một phần lý do là cô sợ bị các bạn người Kinh trong lớp trêu chọc nếu cô không có bạn ở cùng làng.

Hơn nữa, mức độ ham thích học tập khác nhau có thể được giải thích bằng chất lượng của việc dạy và phương pháp sư phạm, điều này phụ thuộc vào cơ sở vật chất và chất lượng của giáo viên. Thứ nhất, cơ sở vật chất của trường tác động đến việc học hành của học sinh. Hầu hết thanh niên ở vùng nghiên cứu bắt đầu học tốt ở trường khi huyện Võ Nhai được tiếp nhận quỹ giảm đói nghèo và nhờ đó những trường này được đổi mới. Nhiều học sinh phàn nàn về điều kiện cơ sở vật chất nghèo nàn ảnh hưởng đến việc học hành của họ.

Khi tôi là học sinh, trường học đơn giản là nhũng ngôi nhà sơ sài. Không nhu trường học ngày nay, chúng tôi không có cơ sở vật chất khang trang hay là nhũng toà nhà lớn. Tôi nhớ là lớp học của tôi ở trong phòng lớn. Có khoảng 50 học sinh, rất khó để tập trung vào việc học tập. Tiếng rất to. Khi học sinh mất trật tự mọi thứ trở nên rất ồn ào.

- Hoan, Kinh, nũu, 24 tuổi, đã kết hôn, làng Al

Trường mà em đã họ chẳng có gì cả. Nó rất sơ sài, vách bằng nứa. Vào mùa đông gió thổi vào trong lớp học. Em cảm thấy rất rét và không thể tập trung vào việc học hành.

- Thanh, Dao, nũu, 29 tuổi, chưa kết hôn, làng A5

Trong khoảng thời gian là học sinh, bọn em phải chịu thiếu nhiều dụng cu và cơ sở vật chất... ví du, học môn sinh học chúng em không có cơ sở vật chất phòng thí nghiệm để thực hành. Tất cả bọn em chỉ học vẹt. Nó không có hiệu quả.

- Tuyền, Kinh, nam, 26 tuổi, làng A2 
Điều kiện học tập thiếu thốn không những không giữ được nhiệt tình học tập mà còn khiến lớp học tan do không có học sinh. Trong khi điều này không xảy ở trường học chính thì ở các lớp trường phân hiệu vẫn còn những trường hợp như thế. Ví dụ, năm 2006 chỉ có 3 học sinh Dao ở làng A5 đi học lớp 1 đúng tuổi. Nhưng từ khi lớp học chỉ mở khi có ít nhất 6 học sinh đến trường thì lớp 1 đã bị huỷ bỏ. Ba học sinh này phải nghỉ để đợi học ở năm sau. Tác động của việc này đến trẻ em có thể là nhỏ nhưng sự gián đoạn này có thế tạo ra sự tụt hậu và dẫn đến việc bỏ học của trẻ ở những lớp học cao hơn sau này.

Hơn nữa, chất lượng dạy học ở đây vẫn là một câu hỏi lớn. Những giáo viên của trường địa phương được phòng giáo dục của huyện Đình Cả tuyển chọn. Rất nhiều người trong số họ không phải người địa phương, họ thường là người ở những xã khác của huyện Võ Nhai. Họ hầu hết là người Kinh, một số là người Tày và Nùng, không ai là người H'mong hoặc người Dao. Năng lực của giáo viên đã được nâng lên trong những năm qua. Vài thập kỷ trước đây giáo viên ở các trường địa phương có thể chỉ học hết phổ thông cơ sở, đến nay, hầu hết các giáo viên ít nhất có bằng cấp sư phạm. Việc khuyến khích giáo viên ở miền núi đã được chú ý trong vài năm qua. Tuy nhiên thông qua phỏng vấn học sinh và cha mẹ họ, vẫn còn nhiều ý kiến về chất lượng dạy học. Nhìn chung, chất lượng giáo dục ở miền núi được coi là kém hơn so với vùng đô thị. Một số thanh niên nói khi họ muốn bỏ học, giáo viên đã gặp họ để khuyến khích, động viên họ tiếp tục đến trường. Nhưng cũng có ý kiến nói rằng thiếu sự khuyến khích của giáo viên đã ảnh hưởng không tốt đến việc học hành của họ. Trong thời gian qua, ở các lớp học thuộc trường phân hiệu giáo viên vắng mặt thường xuyên.

Khi em đi học trường ở đây, cô giáo dạy từ 1 đến 2 tiếng. Sau đó cô cho chúng em nghi đến tận truia khi tan lớp. Bố em cho em đến học ở trường Đình Cả bởi vì chất lượng dạy học ở đây tốt. Em thấy cô giáo ở trường Đình Cả rất đúng giờ và năng động. Họ rất nghiêm túc. Em đã học chăm chí.

- Khải, Tày, nam, 25 tuổi, cán bộ xãa, làng Al

Em đã đến trường nhiều lần nhưng không có giáo viên ở đó.

- Thanh, Dao, nũ , 29 tuổi, làng A5

Giáo viên không tốt. Họ không nhiệt tình trong giảng dạy. Thỉnh thoảng học sinh đi học nhưng cô giáo thì vắng mặt. Khi họ ở đấy họ cũng không dạy học sinh cẩn thận. Họ cũng không quan tâm việc học tập của học sinh.

- Hoan, Kinh, nũu, 24 tuổi, đã kết hôn, làng A

Giáo viên vắng mặt ở những trường phân hiệu nhiều hơn ở trường chính. Như đã trình bày ở phần trước, một số giáo viên đã nói họ miễn cưỡng phải chấp nhận khi được phân công đi dạy ở những trường lẻ. Những giáo viên này thường sống ở những nơi thuận tiện hơn ở trong làng. Tiếp nhận công việc, họ đến dạy ở trường vào những ngày làm việc và trở về nhà vào những ngày cuối tuần. Ở trường tại làng $\mathrm{A} 5$, họ sắp xếp lại 
thời khoá biểu để họ được thuận tiện hơn. Thay vì dạy nửa ngày và dạy trong 5 ngày 1 tuần, giáo viên tổ chức lớp học từ thứ 3 đến thứ 5 . Kết quả là thời gian tiếp xúc giữa giáo viên và học sinh ở trường phân hiệu ít hơn ở trường chính nơi có nhiều học sinh người Kinh hơn. Hiện nay, việc giám sát và kiểm soát chất lượng khó tiến hành ở những vùng miền núi. Không ai yêu cầu giáo viên điểm danh học sinh trong giờ học chính khoá. Khi chúng tôi nghiên cứu tại thực địa vài thanh niên dân tộc thiểu số nói rằng mối quan hệ chưa tốt giữa giáo viên và học sinh làm giảm nhiệt tình của họ khi đến lớp.

Thầy giáo của em (ở trường học tại làng) là người dân tộc Kinh. Chúng em đã rất sợ khi hỏi thâyy nhũ̃ng câu hỏi, đặc biệt chúng em không hiểu tiếng Kinh của thây. Em cảm thấy thầy chú ý nhiều đến nhũng học sinh nói tiếng Kinh.

- Hồng, Dao, nữ, 25 tuổi, học hết lớp 2, làng A5

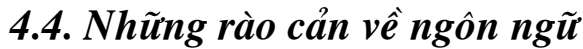

Học vấn thấp ở thanh niên dân tộc Dao và H'mong còn do nguyên nhân nói tiếng Kinh không thành thạo. Ngôn ngữ dân tộc vẫn được sử dụng rộng rãi ở các gia đình. Điều tra cho thấy tất cả các hộ gia đình người H'mong và Dao đều không coi tiếng Kinh là ngôn ngữ chính ở nhà, họ chỉ nói tiếng Kinh khi giao tiếp với người dân tộc khác. Hầu hết các thanh niên dân tộc đều nói họ chỉ bắt đầu học tiếng Kinh khi đi học. Ở các trường trong địa điểm nghiên cứu không có giáo viên người Dao và H'mong. Tiếng Kinh là ngôn ngữ để cung cấp kiến thức cho học sinh. Mặc dù ở trường có nhiều dân tộc khác nhau nhưng các trường địa phương đều phải theo chương trình chuẩn của Quốc gia do Bộ Giáo dục và Đào tạo thiết kế. Cách làm việc này đã tạo nên những thiếu sót một cách hệ thống, sau đây là ý kiến của giáo viên địa phương:

Theo ý kiến của tôi, chương trình thiết kế bởi Bộ giáo dục và Đào tạo quá khó cho học sinh. Thứ nhất là có quá nhiêu môn học. Thứ hai, học sinh ở đây là dân tộc thiểu số họ thiếu nhũ̃ng thông tin về thế giới bên ngoài trước khi đến trường. Giáo viên phải minh hoa bài giảng bằng sử dụng nhũng bức tranh hoạc nhũng phương tiện nghe nhìn khác. Chúng tôi cũng không có điều kiện để giảng nhũ̃ng vấn đề này một cách hiệu quả. Thỉnh thoảng học sinh không hiểu nhũng diêu cô giáo giải thích.

- Hiệu trương trường tiểu học Phương Giao xã Phương Giao.

Hộp 4.3: "Giáo dục bằng nhiều ngôn ngữ ở Việt Nam" còn là một con
đường dài
Hiến pháp của nước Việt Nam tuyên bố tất cả các dân tộc có quyền sủ
dụng ngôn ngữ riêng của mình. Việc sư dụng ngôn ngũ riêng mới chỉ giới hạn
trong dạy học ở một số nhỏ các trường. Những ngôn ngũ dân tộc khác nhau
không được sư dụng trên lớp mà học sinh phải tiếp thu nhũng bài học bằng
tiếng Kinh.


Hướng dẫn của Bộ Giáo dục và Đào tạo chỉ thục hiện bằng tiếng Kinh. Chỉ có 8 ngôn ngữ dân tộc được dạy như là những môn học ở nhà trường. Có ít giáo viên người dân tộc do họ không vượt qua được những khó khăn trong suốt quá trình tiếp thu chương trình giáo dục.

Gần đây Việt Nam có những nỗ lực để tăng cường đa ngôn ngũ trong nhà trường, tổ chúc cúu trợ trẻ em Anh đã làm việc với "những người mẹ chủ chốt" ở những địa phương vùng cao, đào tạo họ những kỹ năng trợ giảng trước khi đến trường vì thế tùng lớp học có những người nói bằng ngôn ngũ hàng ngày của học sinh.

Những người mẹ chủ yếu làm việc với giáo viên để đảm bảo nội dung chương trình và sách giáo khoa phù hợp với hoàn cảnh địa phương và đóng vai một cách chủ động khi sư dụng kỹ thuật dạy. Họ sư dụng ngôn ngũ địa phương để làm rõ những điều giáo viên nói bằng tiếng Kinh. Để giúp những đúa trẻ đến trường tiểu học, tiếng Kinh được giới thiệu trong khi giao tiếp và những đứa trẻ đã quen với bảng chũ cái tiếng Kinh.

Hiện tại, dụ án mới chỉ được tiến hành ở diện hẹp. Theo tổ chúc cúu trợ trẻ em Anh, không thể giới thiệu chương trình song ngũ với tất cả hệ thống giáo dục của Việt Nam trong bối cảnh chính trị hiện tại và trong văi năm tới đây chưa thể thấy hiệu quả của công việc này.

Nguồn: Pinnock, Dinh, và Nguyen. 2006. "Chính sách và thực hành ở Việt Nam" Id21 Insights: Nghiên cứu phát triển giao tiếp, tháng 9 năm 2006.

Mặc dù hầu hết những thanh niên trả lời phỏng vấn bằng tiếng Kinh khá trôi chảy nhưng họ vẫn nói rằng quá trình học của họ rất chậm và họ phải mất vài năm làm quen ở trường để hiểu những điều cô giáo giảng. Trích dẫn sau đây rất điển hình:

Khoảng thời gian khó khăn nhất cho em là khi học lớp 1 và lớp 2. Vào thời gian này, thật khó để có thể hiểu được nhũng điều cô giáo nói. Em không thể đọc và viết. Cô giáo cố gắng để dạy nhũ̃ng tù dễ và yêu câu chúng em nhắc lại lời của cô. Bằng cách như vạy, chúng em học được tiếng Kinh. Cho đến tận lớp 4, lớp 5 em mới cảm thấy thoải mái hơn khi sử dụng tiếng Kinh. Vẫn có nhũ̃ng tù̀ em không biết.

- Xía, H'mong, nữ, 20 tuổi, đang học lớp 12, làng B4

Vì em không biết tiếng Kinh trước khi đi học, em đã không dám nói tiếng Kinh ở trên lớp. Em chỉ ngôi ở trong lớp, giữ im lạng suốt thời gian đó, đợi đến khi tan học em trở về nhà. Cho đến tận lớp 10 em mới hiểu tiếng Kinh. Em đã đúp lớp 1 hai lần. Đây thực sụ là cản trở.

- Thanh, Dao, nam, 26 tuổi, làng A5 
Bởi ngôn ngữ không thành thạo, một số học sinh bị lưu ban vài lần trước khi chuyển lên lớp học cao hơn. Rào cản về ngôn ngữ làm ảnh hưởng xấu trong thời gian dài đối với việc học tập của thanh niên, đặc biệt ảnh hưởng đến học tập của thanh niên khi chuyển lên lớp cao hơn. Trong quá trình làm việc tại địa phương, giáo viên trường trung học đã nhận xét một số học sinh dân tộc thiểu số học tốt như các bạn người Kinh cùng lớp, một số học sinh khác không nói được tiếng Kinh thành thạo. Học sinh dân tộc thiểu số bắt đầu đi học muộn hơn so với tuổi (thường sau 6 tuổi) và phải lưu ban nên khi học trung học phổ thông họ thường nhiều tuổi hơn những bạn cùng lớp. Điều này làm nảy sinh vấn đề về quan hệ xã hội trong học tập. Theo những học sinh dân tộc thiểu số, họ thấy khó chơi với các bạn cùng lớp vì lứa tuổi khác nhau. Tương tự như vậy những học sinh người Kinh thường nhận xét những bạn người Dao hoặc H'mong thường xấu hổ và im lặng khi giao tiếp.

\section{Sự chuyển tiếp từ học tập đến lao động kiếm sống}

Phần này chúng tôi mô tả sự khác nhau trong chuẩn bị học tập tác động đến quá trình chuyển sang lao động. Để làm được điều này, chúng tôi sẽ làm rõ những con đường mòn khác nhau ở nam và nữ thanh niên sau khi rời ghế nhà trường bắt đầu làm kinh tế cho gia đình. Rất nhiều thanh niên bày tỏ mối quan tâm liệu học tập có thể giúp họ kiếm việc làm ngoài làng quê của họ hay không.

Đến tuổi thanh niên dường như họ đã có sẵn kinh nghiệm làm việc đồng áng mà họ vẫn làm khi còn đi học. Điều này đúng với mọi trình độ học vấn, ngay cả khi học trung học phổ thông ở Đình Cả họ vẫn lao động. Rất nhiều việc sẵn có cho trẻ em và thanh thiếu niên liên quan đến nông nghiệp, có thể là lao động phân tán hoặc lao động tập trung. Có khi, thanh niên chính thức trở thành lao động và góp phần vào kinh tế gia đình khi họ học xong. Cũng có khi, những công việc khiến thanh niên trở thành lao động chính, làm mất thời gian của họ dành cho việc học làm họ phải bỏ học.

Có 4 loại hình kinh tế chính cho thanh niên ở vùng nghiên cứu, bao gồm 1) làm nông nghiệp cho gia đình; 2) làm thuê nghề nông nghiệp; 3) phi nông nghiệp cho gia đình và 4) làm thuê các nghề phi nông nghiệp. Phần tiếp theo sẽ xem xét sự dịch chuyển khác nhau giữa người Kinh và người dân tộc thiểu số trong 4 loại hình kinh tế này. Chúng tôi quan tâm đến các yếu tố chính khiến cho một số thanh niên thành công trong việc bước vào cuộc sống lao động trong bối cảnh phát triển nhanh chóng của xã miền núi vùng sâu.

\subsection{Loại hình nông nghiệp gia đình}

Loại hình này thu hút nhiều thanh niên tham gia hơn những loại hình khác. Không kể đến học vấn, nhiều thanh niên, đặc biệt những thanh niên người Kinh chưa có gia 
đình đều mong muốn không phải tham gia lao động nông nghiệp trong gia đình. Hầu hết họ nhìn nhận lao động nông nghiệp là việc làm rất vất vả mà thu nhập thấp. Ý kiến của một thanh niên người Kinh ở tuổi 20 là khá điển hình:

Làm sao tôi có thể đứng làm việc ngoài trời nắng cả ngày. Thỉnh thoảng mùa màng thất thu và chúng tôi chăng thu được gì cả sau tất cả nhũng ngày lao động vất vả. Những gì chúng tôi thu hoạch được thì không đủ để trả tiên phân bón.

Mặc dù có sự nhìn nhận không mấy thiện cảm với công việc đồng áng, nhiều thanh niên vẫn cho rằng nó đảm bảo cung cấp lương thực thực phẩm cho xã hội. Học sinh vừa rời nhà trường sẽ làm nông nghiệp ở gia đình. Những lao động di cư quay trở lại với đồng áng nếu họ thất bại với những công việc ở ngoài quê hương mình. Vẫn có rất nhiều thanh niên trong vùng nghiên cứu - có thể chấp nhận hoặc miễn cưỡng chấp nhận làm nông nghiệp ở gia đình và có thể làm suốt cuộc đời của họ. Nhóm này thường có ít vốn hiểu biết về con người và xã hội, bao gồm cả những thanh niên có trình độ học vấn thấp (học hết trung học cơ sở hoặc thấp hơn) thuộc những nhóm dân tộc thiểu số và ít có quan hệ với thế giới bên ngoài. Nói tiếng Kinh không thành thạo cũng là một nguyên nhân không khuyến khích thanh niên dân tộc thiểu số tìm kiếm công việc ở những nơi khác.

Gia đình đóng vai trò quan trọng trong việc quyết định liệu thanh niên có tiếp tục làm việc đồng áng cùng gia đình hay không. Cha mẹ người dân tộc thiểu số coi đất canh tác là nguồn đảm bảo lâu dài cho cuộc sống hơn người Kinh. Bằng cách làm nông nghiệp, họ có thể không phải đối mặt với những nguy cơ liên quan tới những nghề phi nông nghiệp. Hơn nữa, nhiều người trong làng có cái nhìn bình dị về lối sống ở làng bản và như vậy họ có xu hướng nhìn thấy nhiều ảnh hưởng xấu hơn về cuộc sống ở thành phố. Những thanh niên đã có gia đình thường có nhận thức như vậy. Trích dẫn sau sẽ phản ánh điều đó:

Đất canh tác mang lại cho chúng tôi sự an toàn. Nhũng người công nhân có thể làm việc ở nhà máy suốt cả cuộc đời không? Ho có thể làm gì khi đã già và không có tiền trợ cấp. Nhũng người nông dân có đất canh tác và làm nông nghiệp có thể nuôi họ cả cuộc đời.

- Lưu, Dao, nũu, 44 tuổi, làng A5

Khi làm việc tại nhà an toàn hơn. Nếu cố gắng để giúp những đứa con có việc ở bên ngoài, chúng tôi phải đi vay tiền. Không có gì đảm bảo rằng các con có thể kiếm được việc làm để trả nợ. Tôi và chồng tôi sẽ gặp phải nhiêu vấn đề nếu chúng tôi không thể trả nợ

- Khanh, Dao, nũu, 50 tuổi, làng A5

Làm nông nghiệp là khó khăn nhưng nó có thể làm cho gia đình chúng tôi được sum họp. Không ai phải sống xa nhà. Nếu bạn muốn làm nghề phi nông nghiệp 
thì phải sống ở thành phố. Có một số điều phải lo lắng: tệ nạn xã hội, đánh bạc hay gái mại dâm. Chúng tôi không có tệ nạn xã hội, ở đây khá an toàn.

- Thảo, Kinh, nũu, 26 tuổi, học hết lớp 12, đã kết hôn, làng A2

Cuộc sống ngoài làng này thì không thuận tiện. Em có nhiều lo lăng ở đó. Ở đây em có cuộc sống dễ dàng hơn.

- Dung, Kinh, nũu, 18 tuổi, học hết lớp 9, chưa kết hôn, làng B2

Có một vài thanh niên ở vùng nghiên cứu xác định sẽ cải thiện cuộc sống của họ thông qua lao động nông nghiệp gia đình. Thế hệ nông dân trẻ có sự chuẩn bị giáo dục tốt hơn thế hệ cha mẹ họ. Họ thường bày tỏ những quan tâm của họ đến việc canh tác những loại giống cây mới và chăn nuôi với quy mô lớn hơn. Những con đường liên thôn, liên xóm đã đưa thị trường đến gần hơn với hầu hết người dân. Sự giúp đỡ của chương trình giảm nghèo ở Việt Nam đã thúc đẩy sự phát triển kinh tế nhanh ở vùng nghiên cứu và nâng cao mức sống cho họ. Tuy nhiên hiện tại việc thiếu vốn (cả đất canh tác và tiền đầu tư) vẫn còn phổ biến. Chương trình tín dụng thuộc chương trình giảm nghèo chỉ dành cho một số hộ gia đình. Hầu hết những thanh niên không tiếp cận được với chương trình tín dụng này. Họ phải dựa trên nguồn vốn của gia đình vì vậy những cách giải quyết khó khăn của họ rất hạn chế. Những hạn chế như vậy được thấy trong trích dẫn sau đây:

Tôi muốn học nhiều hơn nữa về canh tác phù hợp với đất đai của tôi. Tôi muốn trồng thêm một vài loại cây trông và xem loại nào tốt nhất. Tôi không biết sẽ băt đầu như thế nào. Tôi muốn vay 3 triệu tù chương trình tín dụng. Nhưng tôi không biết tôi có được phép vay không.

- Vinh, Kinh, nam, 23 tuổi, chưa kết hôn, học hết lớp 9, làng B3

Trong khi vùng nghiên cứu cũng như những nơi khác của huyện Võ Nhai đang phát triển để hoà nhập với thị trường thế giới (đặc biệt sau khi Việt Nam gia nhập WTO), hầu hết những thanh niên có gia đình đang làm nông nghiệp không có đủ kiến thức về kỹ thuật. Thiếu kiến thức làm cho họ khá khó khăn để theo kịp sự thay đổi nhanh chóng của kinh tế - xã hội. Hầu hết người dân không có thói quen đọc báo. Vô tuyến gần đây mới có. Có thể những phương tiện truyền thông mới sẽ tác động tốt tới nghề nông.

Chúng tôi đã từng trồng mía. Thời gian đó chúng tôi có thể bán được 2.000 đồng/kg. Sau đó chúng tôi đã không trồng nũa vì nghe nói nhu cầu mía thấp. Chúng tôi không biết mùa mía này chính phủ đang tăng cường cho xuất khẩu và đang phát triển ở thị trường thế giới. Bây giờ giá đường đã tăng lên 7.000 đông/kg. Vì không có thông tin chính xác, chúng tôi đã lỡ một cơ hội tốt.

- Vinh, Kinh, nũu, 23 tuổi, học hết lớp 9, chưa kết hôn, làng B3 


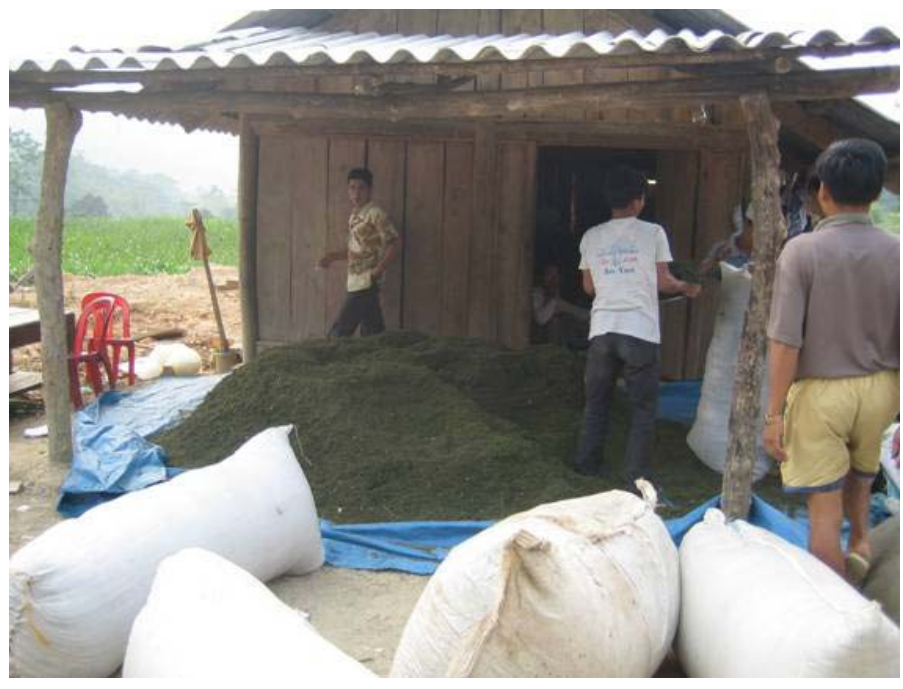

Link 12. Thank hao hoa vàng tượe tóng bao và chuyến khơi làng C3. Oài năm trước đây, $1 \mathrm{~kg}$ thank hoa có thể bán đượe trên 10.000,00 đồng. Măm 2006, giá thank hoa giaim xuống còn 2.000 đồng làm cho nhiều hộ gia đinh trở nên nơ nần. Kink tế cúa làng phát triền cùng oới thị truiờng thế quới đề lại phía sau nhiều hộ

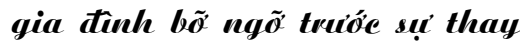
tổi kinh tế uhank chóng.

\subsection{Hình thức làm thuê nông nghiệp}

Những thanh niên ở vùng nghiên cứu không chỉ làm việc trên đất canh tác của gia đình mà họ còn làm ở nơi khác như những lao động làm thuê nông nghiệp. Hầu hết người dân làm nghề này sau mùa thu hoạch, chỉ một số người làm quanh năm. Làm nông nghiệp ngoài gia đình có thể ở chính làng của họ hoặc làng bên, xã bên. Công việc này thường yêu cầu thanh niên phải đi làm trong khoảng thời gian ngắn từ vài ngày đến vài tuần. Trong vài năm qua, những cơ hội cho loại việc làm này tăng lên ở đây. Điều này đặc biệt đúng với những làng người Kinh ở nhóm $\mathrm{B}$ có kinh tế phát triển hơn. Ở nhóm $\mathrm{B}$, số hộ gia đình có nguồn thu nhập ban đầu từ tiền gửi, dịch vụ và buôn bán hơn là từ làm nông nghiệp đã tăng lên.

Nghề này không đòi hỏi những kỹ năng cao nhưng lao động rất vất vả. Tiền công khoảng từ 20.000 đến 30.000 đồng/ngày (xem chương 3). Thanh niên dân tộc thiểu số và những người học vấn thấp thường làm nghề này.

Gia đình em có ít đất canh tác. Em phải làm cho nhà khác để hỗ trợ cho gia đình. Em thường làm thuê ở làng này. Em giúp họ chăm sóc đất canh tác, thu hoạch ngô hoạc trồng lúa. Có nhiều việc để làm quanh năm.

- Huệ, Sán Dìu, nũ, 25 tuổi, có 2 con, làng B1

Em làm thuê 2 ngày/ tháng. Rất dễ kiếm việc làm. Em luôn làm cho người Kinh ở làng bên cạn .

- Du, H'mong, nư, 29 tuổi, có 4 con, làng B4

Em giúp cắt cỏ và dọn dẹp đất canh tác. Thỉnh thoảng em đi vác gỗ thuê. Rất nhiều người làm thuê như em. Chúng em làm trên đất canh tác nhà mình. Sau khi làm xong, em đi làm cho nhũ̃ng người khác. Em làm thuê ở ngoài rất nhiều... Em 
quá bận, thỉnh thoảng em phải trông con, may mà có mẹ em giúp. Con gái em bây giờ đang đi mẫu giáo. Buổi sáng em đưa cháu đến trường. Cháu đi bộ về nhà cùng với các bạn khi em đi làm buổi chiều.

- Xuân, Dao, nũu, 24 tuổi, bỏ chồng có con gái 4 tuổi, ở làng A4

Hầu hết thanh niên làm thuê để có nguồn thu nhập khác cho gia đình. Gần đây, số lượng nam và nữ thanh niên ở địa điểm nghiên cứu đi vác và xẻ gỗ một nghề kinh doanh đang phát triển ở Võ Nhai tăng lên.

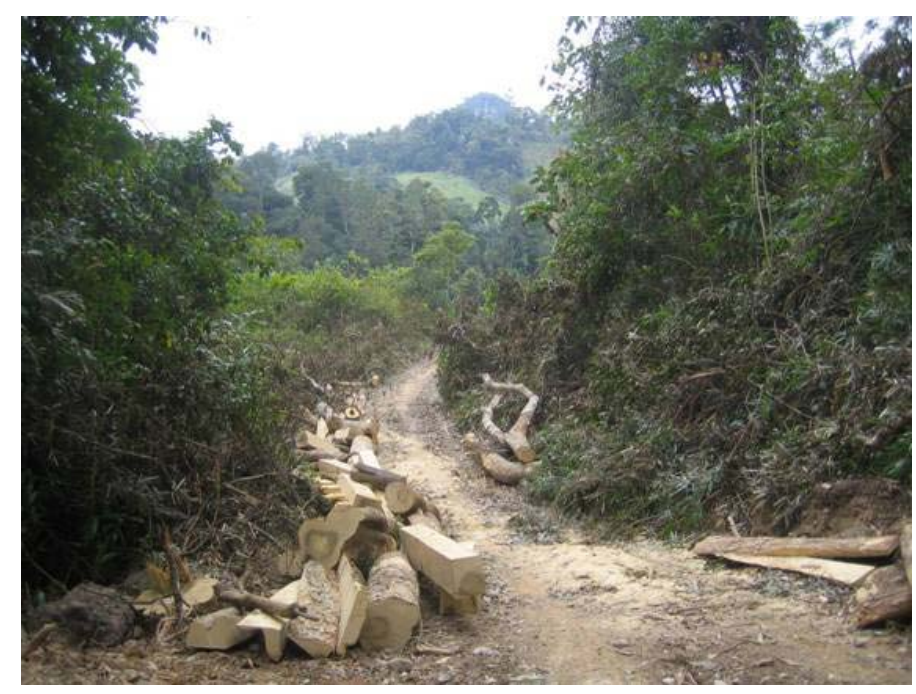

Link 13. Dhũing khúc gễ mà̀m trên tường đi cía làng 45 (nquiò̀i Dao, vìng xea). Dhiều phụ mĩ và nam giới đã làm nghề xé gễ và vác qũ̃ thuê hàng ngày cho whüngy chù khai tháe

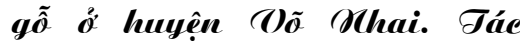
tộng của ngành khai tháe gố này đến môi trường ỗún chuia đượe chí ý.

Em có thể kiếm được 100.000 đông hoặc nhiều hơn một ngày. Nếu em đi rùng xẻ gỗ thường xuyên, em có thể kiếm được tù̀ 1 đến 2 triệu đồng/tháng. Em nói với me em bán trâu đi để có tiền mua máy xẻ. Nhưng mẹ em không đồng ý. Họ nói làm việc đó quá nguy hiểm.

- Tài, Dao, nam, 26 tuổi, học hết lớp 5, đã ly dị, làng Al

Thỉnh thoảng em đi vác gỗ thuê ở trên rừng. Mỗi khúc gỗ em kiếm được 15 ngàn đồng. Khi em khoẻ em vác gỗ đến nơi mất khoảng 2 tiếng. Khi em yếu thì mất khoảng 4 tiếng.

- Xuân, Dao, nũu, 24 tuổi, đã ly dị có con gái 4 tuổi, làng A4

Việc làm thuê cho những người kinh doanh xẻ gỗ dường như có lợi; tuy nhiên, chỉ có vài người nhận thức hoặc có quan tâm đến tác động của loại hình kinh doanh này đến môi trường. 


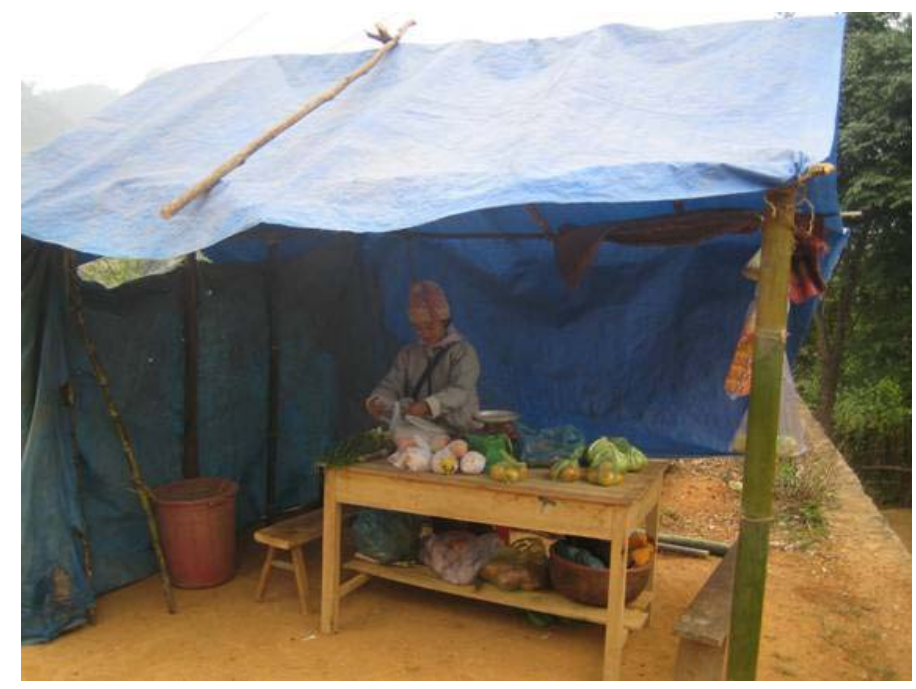

Cinh 14. Bán rau và hoa quả ở làng A2. Oì thiếu vốn chi có vài gia đink kink doank whó ơ làng A2. Loại hìnk này còn điều kiện đtề phát triến.

\subsection{Hình thức phi nông nghiệp gia đình}

Đây là hình thức kinh tế có tiềm năng phát triển ở vùng nghiên cứu. Hiện tại, chỉ có những người chịu khó mới tham gia vào việc kinh doanh phi nông nghiệp. Họ làm như người Kinh nên có điều kiện kinh tế xã hội tốt hơn so với những người còn lại ở trong làng. Những người dân ở nhóm $\mathrm{B}$ thích loại hình này hơn nhóm $\mathrm{A}$ vì họ dễ tiếp cận với Đình Cả và chợ Đông Bo. Nhìn chung nhóm $\mathrm{B}$ có thu nhập cao hơn nhóm $\mathrm{A}$.

Hầu hết các cửa hàng ở vùng nghiên cứu bán thức ăn và đồ dùng gia đình. Khi số hộ gia đình kinh doanh tăng lên, họ sẽ kinh doanh các sản phẩm và dịch vụ khác nhau. Ví dụ một nữ thanh niên người Kinh mới mở hiệu may ở làng $\mathrm{B} 3$, khách hàng của cô bao gồm cả người Kinh và H'mong. Vào thời gian nghiên cứu, vài thanh niên dân tộc thiểu số cũng tỏ ra muốn kinh doanh. Những chủ kinh doanh trẻ thường có những hiểu biết về cuộc sống ngoài thôn làng của họ. Một số thanh niên muốn kinh doanh chuyên nghiệp. Tuy nhiên, thiếu vốn và sự hỗ trợ của gia đình đã ngăn cản sự đầu tư vào những thứ mà họ quan tâm.

Em và chồng em muốn mở cửa hàng sứa chũa xe máy... Loại này có lẽ sẽ kinh doanh tốt ở đây. Nó không cần đâu tu nhiêu lắm và bây giờ nhiều gia đình đã mua xe máy. Tuy nhiên bố me chông em không hỗ trợ chúng em. Họ nghĩ là quá mạo hiểm để vay tiền đầu tư vào bất kỳ loại kinh doanh nào.

- Thảo, Kinh, nũu, 26 tuổi, học hết lớp 12, làng A2

\subsection{Hình thức làm thuê phi nông nghiệp}

Rất nhiều thanh niên trẻ trong vùng nghiên cứu mong muốn có nghề phi nông nghiệp. Cả thanh niên và gia đình đều nhận thấy làm những nghề này sẽ không cần 
lao động vất vả và thu nhập có thể nhiều hơn so với công việc đồng áng. Những hộ gia đình ở làng nghiên cứu muốn cho những thành viên trong gia đình, đặc biệt là thanh niên làm nghề phi nông nghiệp coi đó là một cách để làm đa dạng hoá nguồn thu nhập.

Em có người ho hàng trẻ hơn làm việc ở nhà máy may. Cô ấy kiếm được gần 1 triệu đông/ tháng. Trong làng này bọn em phải làm việc rất vất vả trong vài tháng mới kiếm được bằng đấy tiền.

- Phương, Dao, nũu, 29 tuổi, học hết lớp 5, làng A4

Năm ngoái em làm công nhân xây dựng ở nhà máy tỉnh Hải Dương. Nhà máy đấy cách nhà em khoảng $180 \mathrm{~km}$. Em phải làm việc này vì em cần phải kiếm tiền để giúp bố me trả khoản nợ từ việc làm nông nghiệp. Năm ngoái ở đây bị hạn hán. Gia đình em không thu hoạch được gì cả, thậm chí còn phải vay tiền để trả tiền phân và giống.

- Tâm, Kinh, nam, đã kết hôn, làng B2

Hơn nữa, từ khi trong xã có nhiều người làm thuê phi nông nghiệp ở nơi khác ngoài xã, một số thanh niên xem đây là cơ hội để mở rộng tầm nhìn ra thế giới bên ngoài.

Khi em làm ở ngoài xã này (công nhân bốc vác) em thấy nhiều cái mới mà trước đó em không biết. Ví dụ, em nhìn thấy máy cày người ở các tỉnh khác sủ dụng trong quá trình trồng lúa. Người ta không dùng trâu như nhiêu người ở đây.

- Sơn, Kinh, nam, 17 tuổi, học hết lớp 9 làng B3

Có hai con đường cho ngành kinh tế này, con đường thứ nhất là con người sẽ lao động ở những nơi cần lao động kỹ thuật như trong nhà máy hay các cơ sở bảo dưỡng kỹ thuật. Con đường thứ hai là thanh niên làm các công việc tại chỗ như giáo viên, nhân viên văn phòng ở chính quyền địa phương. Trong vùng nghiên cứu, nhiều thanh niên chọn con đường thứ nhất hơn con đường thứ hai.

Tuỳ thuộc vào loại công việc, người chủ, địa điểm làm việc và mức tiền công, nhân công lao động được yêu cầu có trình độ học vấn ít nhất là trung học cơ sở (ví dụ như lớp 9), những kỹ năng đòi hỏi để phù hợp với yêu cầu của công việc rất khác nhau. Những thanh niên tìm việc thường thích có công việc lâu dài (làm ở nhà máy nước ngoài hoặc liên doanh) nơi họ có thể lĩnh lương tháng và có các lợi ích kèm theo khác. Tuy nhiên, nhiều người trong số họ đã làm những việc phi nông nghiệp với những hình thức ngắn hạn, thường là lao động tập trung, trả lương ngày và không có các lợi ích khác. Người Kinh thường chọn công việc yêu cầu có trình độ học vấn nhiều hơn người dân tộc, họ coi đó là điều kiện để có thu nhập cao. Con đường thứ hai ít phổ biến hơn ở vùng nghiên cứu, ít việc phi nông nghiệp hơn và những lao động trẻ có ít thông tin về loại công việc này hơn những loại công việc khác. Thêm vào đó, những việc loại này thường yêu cầu trình độ học vấn cao hơn, thường là trung học phổ thông. Những thanh niên chấp nhận con đường thứ hai hầu hết là người Kinh. 
Mục tiêu cuối cùng của em là trở thành cô giáo. Nhưng nếu em không thể vào cao đẳng năm nay em sẽ đi học may và sau đó em sẽ kiếm việc làm ở nhà máy may.

- Luyến, Kinh, nũu, 20 tuổi, học hết lớp 12, ở làng A2

Khung 4.4: Cuộc sống ngoài làng: công nhân nhà máy ở thành phố Thái Nguyên

Lần đầu tiên nhóm nghiên cúu gặp Hoa, cô đang làm ở nhà máy may ở thành phố Thái Nguyên. Người con gái Kinh 19 tuổi làng $A 3$ cảm thấy lạc quan về triển vọng nghề nghiệp của minh.

Hoa học nghề may theo thông báo của hội phụ nũ xã Phương Giao. Cô học cách cắt may ở nhà máy mà không phải trả bất cú lệ phí nào. Hoa đã phàn nàn về điều kiện lao động của cô. Cô phải làm việc bắt đồu từ 7 giờ sáng và kết thúc khoảng 8 đến 9 giờ tối. Cô ta không có thời gian để đi chơi với bạn bè. Cô tụ thuê nhà ở. Cô bắt đầu làm từ tháng 2 năm 2006 nhưng không thể tiết kiệm được tiền vì chi phí đắt đỏ ở Thái Nguyên. Lương tháng của cô là 500.000 đồng.

Mặc dù điều kiện làm việc khác xa so với mong muốn, Hoa đã hy vọng mọi điều sẽ tốt đẹp hơn trong vài tháng tới. Cô cũng có ý nghĩ chuyển đến làm việc ở nhà máy may tại Hưng Yên, nơi bạn cô nói lương có thể cao gấp 3 lần.

Hai tháng sau chúng tôi gặp Hoa ở làng của cô. Cô mới bỏ việc ở nhà máy may Thái Nguyên. Hoa nói với chúng tôi rằng phòng tổ chúc yêu cầu cô nộp lệ phí xin việc. Cô ta không thể có số tiền đó để trả vì thế cô bỏ việc. Tuy nhiên, người hàng xóm của cô lại kể với chúng tôi câu chuyện khác. Theo người này, Hoa thôi việc vì đã nghỉ chăm sóc anh bị thương ở bệnh viện mà không xin phép.

Không rõ về lý do Hoa bỏ việc, không có sụ nghi ngờ nào về việc Hoa và nhiều thanh niên của Thái Nguyên sống ở những xã miền núi, vùng sâu muốn sống và làm việc ngoài nghề nông đã gặp bất lọi trong thị trường cạnh tranh nghề nghiệp của Việt Nam, tụt lại phía sau của quá trình công nghiệp hoá.

Trong thời gian làm việc ở cộng đồng, chúng tôi thấy thanh niên tìm kiếm công việc phi nông nghiệp luôn bày tỏ nguyện vọng muốn ở gần nhà nếu cơ hội kinh tế sẵn có. Tuy nhiên, có rất ít những cơ hội phi nông nghiệp thường xuyên hoặc không thường xuyên ở Phương Giao, Tràng Xá, thậm chí cả ở Đình Cả. Nghề chính ở đây chỉ có thể là nhân viên nhà nước ở huyện hoặc xã $\tilde{a}^{5}$.

5 Hiện tại nhiều phụ nữ người Kinh nhóm $A$ học ở trường Sư phạm thành phố Thái Nguyên để trở thành giáo viên mầm non. Họ hy vọng rằng sẽ có cơ hội làm việc ở các trường địa phương; tuy nhiên, những vị trí này được biết là rất ít có nhu cầu và nhu cầu bây giờ thấp hơn trước đây. 
Thực sự là khó khăn để tìm được vị trí văn phòng ở uỷ ban nhân dân. Em biết vài bạn học kếtoán. Họ hy vọng sẽ tìm được vị trí kế toán ở uỷ ban khi uỷ ban thông báo mở rộng nhân sứ. Nhưng mà chỉ có một người trong số ho tìm được việc làm. Gia đình bạn ấy biết một số nguơờ và phải trả 10 triệu đông cho phí xin việc. Số bạn còn lại của em đã không tìm được việc làm.

- Vinh, Kinh, nũ, 23 tuổi, nông dân, làng B3

Với những cơ hội rất hạn hẹp ở vùng nghiên cứu, thanh niên muốn có thu nhập nghề phi nông nghiệp cần đi ra ngoài huyện Võ Nhai. Để kiếm được việc làm tốt thường xuyên, họ thường phải đến thành phố Thái Nguyên hoặc ngoại thành Hà Nội. Một số đi xa như đến phía Nam xung quanh thành phố Hồ Chí Minh. Nhìn chung, có ít cơ hội làm việc ở các nhà máy ở phía Bắc hơn là ở phía Nam, điều này được thể hiện qua ý kiến sau:

Rất khó để tìm việc trong nhà máy điện ở phía Bắc. Nhu câu làm nghề này rất nhiều. Bạn cần phải có trình độ nhất định. Bạn cũng cân có tiền. Một người bạn của tôi nắm giũ vị trí quan trọng trong xã này nói rằng gia đình anh ta phải trả 40 triệu đông để cho con trai anh ta có công việc này ở gần Hà Nội. Sau khi nghe thấy thế tôi tù̀ bỏ luôn mong muốn tìm việc cho con tôi ở nhũ̃ng nhà máy. May măn, chúng tôi nghe thấy vài cơ hội ở phía Nam. Rẻ hơn và dễ tìm việc hơn.

- Nghĩa, Tày, nam, gia đình khá giả, làng Al

\section{Khung 4.5: Sống ngoài gia đình: Lao động di cư đến miền Nam}

Tuyền là người có học vấn cao nhất mà nhiều thanh niên trong làng của anh mong muốn. Nam người Kinh, 24 tuổi, làng A2 học hết trung học phổ thông và có hai năm học nghề điện ở trường Cao đẳng của Thái Nguyên. Tuyền dường nhu khởi đầu rất tốt. Nhưng quá trình chuyển tiếp từ học hành đến công việc của anh không phải là con đường màu hồng.

Ngay sau khi tốt nghiệp trường cao đẳng kỹ thuật, Tuyền kiếm được việc ở nhà máy mỏ La Hiên-nhà máy nằm trên đường bắt đầu vào huyện Võ Nhai. Tuyền đã làm ở đó 3 tháng nhưng kết quả cuối cùng là nhà máy giảm biên chế. Đây là lý do nhiều thanh niên bỏ việc. Tuyền mất việc và trở về nhà.

Hy vọng của anh ta lại sáng lên đến đầu năm 2006 khi người hàng xóm nói với anh ta có cơ hội kiếm việc làm ở một nhà máy điện phía Nam. Để có việc này, Tuyền đã trả 5 triệu đồng lệ phí xin việc, đây là số tiền gia đình Tuyền đã phải bán trâu. Bố anh cho anh 9 triệu để nộp lệ phí xin việc và chi phí vào miền Nam.

Mọi việc dường như đã được như mong muốn, cho đến khi vài tháng sau đó Tuyền bị đau lưng và phải nằm viện. Anh đã phải tiêu hầu hết số tiền anh có cho việc chữa bệnh. Sau khi mất vài triệu cho hoá đơn của bệnh viện, vì sụ 
lo lắng của bố nên Tuyền quyết định bỏ việc và trở về nhà. Tuyền làm việc ở nhà máy đó 3 tháng nhưng không kiếm được gì và cũng không thể lấy lại 5 triệu lệ phí xin việc.

Bây giờ Tuyền ở nhà cảm thấy nản lòng vì những gì anh đã trải qua ở miền Nam. Anh lại đang tìm việc ở nhà máy. Bây giờ, anh ta sợ quay lại phía Nam vì mất nhiều tiền mà gia đình anh ta khó khăn mới kiếm được. Bất kỳ việc gì gần nhà đều làm anh ta hài lòng.

Trong vài năm qua, có xu hướng lao động Việt Nam đi làm việc ở nước ngoài như Đài Loan và Malaysia. Những công nhân lao động người Kinh thích đi lao động nước ngoài hơn là dân tộc thiểu số. Việc làm sẵn có cho công nhân Việt Nam ở cả Đài Loan và Malaysia là những lao động tập trung và đòi hỏi trình độ, kỹ năng thấp. Khoảng 5 năm trước đây, nữ thanh niên (thường là những người đã có gia đình) ở làng đã bắt đầu đi lao động ở Đài Loan. Hầu hết họ là người Kinh của nhóm $\mathrm{B}$. Họ thường làm những việc như giúp việc nhà hay chăm sóc người bệnh, người già của gia đình người Đài Loan trung lưu (xem hộp 4.6). Họ phải làm việc ở Đài Loan trong 3 năm. Một số người trong số họ đã trở về nhà. Từ khi những người này trở về dường như khá thành công, những người dân trong làng có thái độ ủng hộ đối với những lao động xuất khẩu tới Đài Loan.

\section{Khung 4.6: Lao động xa quê hương: Làm việc ở Đài Loan}

Đến nhà của Duyên mọi người có thể cảm nhận một cách dễ dàng đây không phải là một gia đình ở làng B3, một xã nghèo của Thái Nguyên. Những dấu hiệu về sụ du dột ở mọi nơi. Một chiếc xe công nông đỗ ở trước nhà. Trong nhà có tivi, đầu DVD, tủ lạnh và góc học tập rất đầy đủ của cô con gái 9 tuổi, có nhiều đồ sang trọng trong nhà. Duyên là một câu chuyện thành công của người đi xuất khẩu lao động trở về.

Ba năm trước đây, cô 24 tuổi và chồng của cô là anh Vũ nhận ra chỉ có một cách để gia đình cô thoát khỏi nghèo là cô đi lao động ở Đài Loan xa nhà hơn 17.000 km. Họ có được cơ hội nghề nghiệp khi một công ty ở Hà Nội đến xã Tràng Xá tuyển người.

"Chúng tôi quyết định tôi nên đỉ Đài Loan vài năm. Chồng tôi ở nhà chăm sóc con" Duyên cười và nói khi đang mặc quần bò, áo xanh dài tay khác xa với nhiều người phụ nữ khác đã kết hôn ở lúa tuổi của cô đang mặc. Cô tiếp tục "sau đó tôi đã không sợ. Tôi chỉ muốn làm gì đó để giúp chúng tôi tốt hơn trong tương lai".

Người đến tuyển ban đầu đòi 1.000 đô la nhưng cô không thể cố gắng có được số tiền đó. Duyên và hai người bạn gái đã đi Hà Nội để tìm công ty khác 
có giá rẻ hơn. Cuối cùng cô cũng tìm được công ty chỉ đòi tiền vé đỉ lại và chiết khấu cho họ tiền lương của cô khi cô bắt đầu làm việc. Trước khi đi Đài Loan, Duyên học tiếng Anh và nấu ăn. Cô cũng học cách sư dụng các đồ dùng điện tử hiện đại trong gia đình.

Công việc của Duyên ở Đài Loan là chăm sóc người cao tuổi. Cô sống với gia đình mà cá hai vợ chồng đều lái xe taxi. Khi cọ̆p vợ chồng này có con, họ không có thời gian để chăm sóc cha mẹ già. Ở Đài Loan cô làm việc tất cá các ngày trong tuần. Mặc dù có rất it thời gian để nghỉ ngơi hoạcc đi chơi, điều kiện làm việc của Duyên khá tốt. "Tôi có phòng riêng trong ngôi nhà của họ, Người chủ của tôi rất hào phóng. Họ đưa tôi đi mua sắm mấy lần” Duyên nói.

Thích thú với công việc chăm sóc người già nhưng cô vẫn nhớ gia đình mình, đặc biệt là con gái. Cô liên lạc với gia đình bằng cách viết thư. Hiếm khi cô có cơ hội nói chuyện với chồng và con vì lúc ấy ở làng cô không có điện thoại. Năm thú nhất, Duyên chưa tiết kiệm được nhiều vì phải trả nọ. Năm thú hai ở Đài Loan, người phụ nư dân tộc Nùng này hàng tháng có thể tiết kiệm được 2,5 triệu .

Đến năm thú ba ở Đài Loan, Duyên bị mắc bệnh bướu cổ và cần phải phẫu thuật. "Tôi đi khám ở Đài Loan. Họ cho tôi một ít thuốc nhưng bướu cổ không khỏi. Tôi không có thẻ bảo hiểm y tế để chi trả phí phẫu thuật. Quan trọng hơn, tôi không biết tiếng và không có gia đình chăm sóc sau phẫu thuật” Duyên giải thích. Sau khi trở về Việt Nam cô đi phẫu thuật ở Thái Nguyên và mất 1 tháng sau để hồi phục.

Mặc dù trở về nhà trước 6 tháng so với dụ tính, cô cố gắng tiết kiệm tiền để mua những thú đắt tiền trong gia đình bao gồm cá xe công nông cho chồng. Bây giờ vợ chồng cô không còn chỉ trồng lúa nữa. Thu nhập chính của họ là vận chuyển các sản phẩm nông nghiệp đến chọ. Họ thuê người trong làng trồng lúa cho họ. Duyên đang muốn quay trở lại Đài Loan. Cô nghĩ nếu cô làm việc ở Hà Nội hay miền Nam không thể kiếm được nhiều như ở Đài Loan.

"Tôi thích Đài Loan. Đài Loan rất đẹp và sạch. Cũng như mọi nơi có cả người tốt và người xấu nhưng nhìn chung người Đài Loan lịch sụ. Đất nước đẹp hơn Hà Nội nhiều lần". Duyên tâm sụ.

Ở cả hai nhóm nghiên cứu những năm gần đây có xuất khẩu lao động đến Malaysia. Những người tuyển chọn từ Hà Nội đến địa điểm nghiên cứu để tuyển thanh niên nam và nữ làm việc ở các nhà máy của Malaysia. Người dân ở đây không rõ sẽ làm công việc gì ở Malaysia. Một số người nói rằng con trai của họ làm ở những nhà máy sản xuất đồ nội thất, một số khác nói là những nhà máy pha chế. Yêu cầu khá thấp, mặc dù những người công nhân được yêu cầu phải trải qua kỳ khám sức khoẻ và lớp 
học chuẩn bị trước khi đi Malaysia. Những người công nhân phải trả tiền đào tạo và các chi phí khác cho lớp học. Trong thời gian nghiên cứu, vài thanh niên người Dao nhóm A đã đi Malaysia, một số người Kinh trong làng đã và đang chuẩn bị đi. Vì chưa có ai trở về và chưa ai gửi tiền về nên cả người Kinh và người dân tộc thiểu số không đánh giá cao lao động ở Malaysia.

Mặc dù rất nhiều thanh niên trong địa điểm nghiên cứu muốn có công việc trong hình thức phi nông nghiệp chính thức nhưng chỉ vài người đạt được mong ước đó. Theo phỏng vấn sâu và quan sát, có một số nguyên nhân quan trọng giải thích tại sao một số người thành công và một số lại không thành công. Giáo dục là một trong các yếu tố cơ bản nhất. Như đã đề cập đến ở phần trước, hầu hết các nghề đều có yêu cầu ít nhất học hết trung học cơ sở. Giáo dục trung bình đạt được ở vùng nghiên cứu với những người ở độ tuổi 20 là tiểu học. Vì vậy họ chưa đạt được trình độ yêu cầu tối thiểu.

Anh rể em ở Tuyên Quang nói với em có rất nhiều nghể ở đó nhũ̃ng yêu câu có bằng tốt nghiệp hoặc chứng chỉ nào đó. Em không có gì cả nên không thể nộp đơn được.

- Tài, Dao, nam, 26 tuổi, làng Al

Yếu tố quan trọng khác là điều kiện kinh tế của gia đình. Khi người lao động tìm kiếm việc làm ở nhà máy, họ luôn được yêu cầu nộp "phí tuyển dụng" cho người tuyển chọn hoặc phòng tổ chức cán bộ. Phí tuyển dụng nhiều ít khác nhau tuỳ thuộc vào tính cạnh tranh của nghề nghiệp đó. Vì chi phí rất cao - gấp hai lần thu nhập hàng năm của hộ gia đình trong vùng nghiên cứu nên nhiều người không thể cố gắng để nộp đơn.

Một người chị gái của em đã có bằng kế toán tù̀ trường hướng nghiệp. Chị ấy không thể kiếm được việc làm. Gia đình em nghe thấy bảo tù̀ 20 đến 30 triệu đông cho người có trình độ tù̀ trường hướng nghiệp. Để có được khoản tiên đó nhà em phải bán 0.15 hecta đất canh tác. Tổng số nhà em chỉ có 0.25 hecta đất. Bố mẹ em không thể cố gắng giúp chị ấy có nghề. Chỉ những gia đình khá giả mới có thể.

- Vĩnh, Kinh, nũu, 23 tuổi, Kinh, nông dân, làng B3

Nhiều thanh niên có nguyện vọng muốn đi lao động ở nước ngoài nhưng họ không được quan tâm vì họ không đủ tiền để trả cho các chi phí liên quan đến đi lại và quản lý. Ví dụ chi phí liên quan đến đi Malaysia với hợp đồng dưới 2 năm ước tính khoảng 20 triệu đồng. Già làng $\mathrm{B} 3$ kể gia đình phải chấp nhận rủi ro để có thể vay tiền ở ngân hàng hoặc bán của cải trong nhà như trâu, bò. Vĩnh là một phụ nữ ở làng $\mathrm{B} 3 \mathrm{kể}$ về sự thất bại của gia đình cô như sau:

Em gái tôi đã nộp đơn đi Malaysia sau khi nghe một phụ nũ ở Đình Cả. Gia đình tôi đã chi 3-4 triệu đồng cho em tôi để chuẩn bị cho chuyến đi, em tôi đã có hộ chiếu, nó cũng đã học ngoại ngũu nủa tháng. Gia đình đã có kế hoạch đi vay ngân hàng 20 triệu đồng đề trả tiền vé và tiền đặt cọc. Ngân hàng nói rằng gia đình phải trả trong vòng ba năm nếu không tiên lãi suất sẽ tăng lên theo 
cấp số nhân. Trước khi đi vay tiền, em gái tôi lại nói là không muốn đi Malaysia nũa. Nó đã biết rằng tiên lương chỉ là 1,8 triệu đồng/tháng. Em ấy phải nộp thuế. Sau khi nộp thuế sẽ còn lại 1,4 triệu đông/tháng. Tù khi thức ăn và giá cả ở Malaysia đắt nó cân ít nhất 1 triệull tháng. Nhu vậy có nghĩa là nó không đủ tiền để trả nợ. Vì vậy em quyết định không đi. Vài thanh niên trong làng ban đâu cũng có kế hoạch đi nhưng sau đó cũng đã quyết định thôi không đi nũa.

- Vĩnh, Kinh, nũu, 23 tuổi, nông dân, làng A3

Không chỉ học vấn và điều kiện kinh tế là quyết định, tổ chức xã hội cũng đóng vai trò quan trọng cho người dân có việc làm phi nông nghiệp tốt. Hầu hết những thanh niên đi làm thuê hình thức này đều nghe về công việc và nhận được sự hỗ trợ từ các thành viên trong gia đình hoặc họ hàng, bạn bè của gia đình những người sống ở thành phố hoặc thường có mối quan hệ với những người ở ngoài huyện Võ Nhai. Nhiều người dân tộc thiểu số ở vùng nghiên cứu có họ hàng sống ở ngoài huyện Võ Nhai, nên họ vẫn có những quan hệ xã hội dù họ vẫn sống ở nông thôn vùng sâu vùng xa. 


\section{Chương V \\ QUÁ TRÌNH ĐI ĐẾN KẾT HÔN VÀ TRỞ THÀNH CHA ME,, NHỮNG LIÊN QUAN ĐẾN TìNH DỤC VÀ SỨC KHOẼ SINH SẢN}

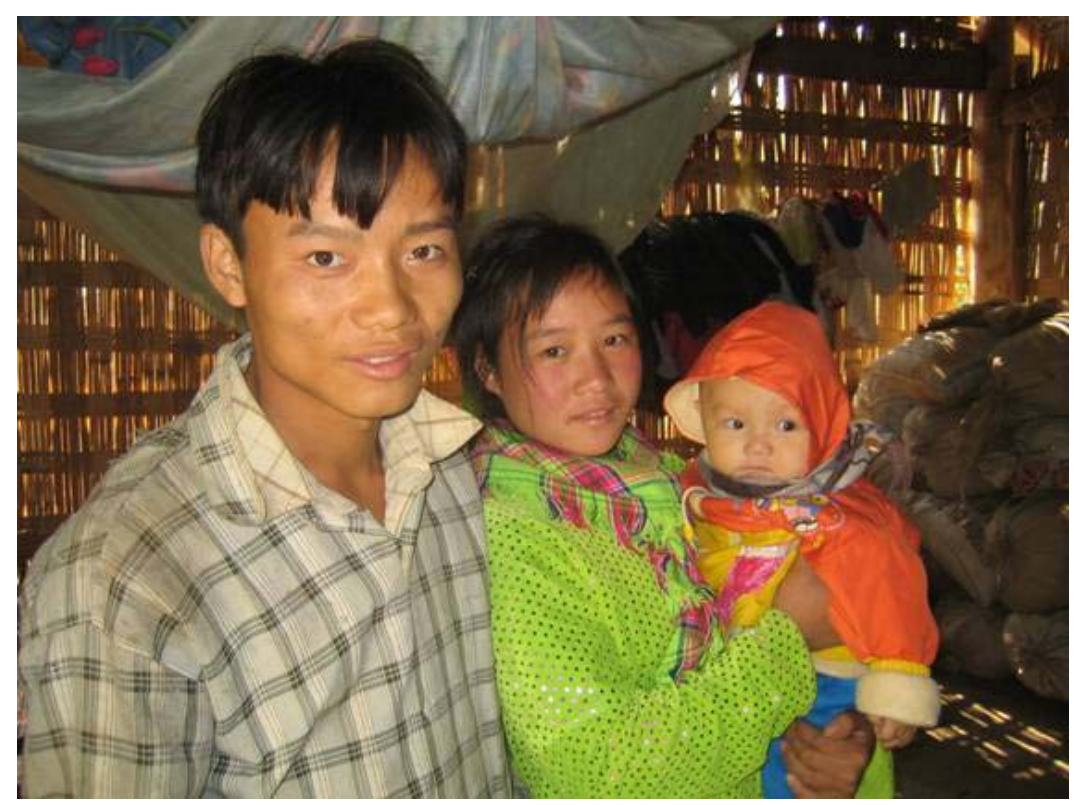

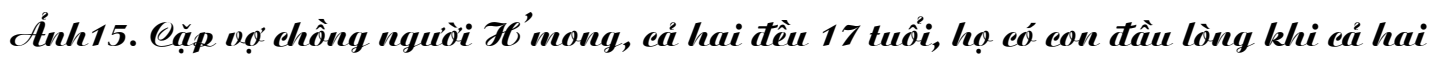
16 tuổi. Tảo hôn còn phổ biến trong thank niên dân tộe thiểu số ở đây.

\section{Giới thiệu}

Thực tế cho thấy thanh niên dân tộc thiểu số có thể gặp nguy cơ sức khoẻ sinh sản và tình dục lớn hơn người Kinh với nhiều lý do khác nhau. Thứ nhất, khuynh hướng hành vi tình dục trước hôn nhân ở các dân tộc thiểu số chẳng hạn như người H'mong lớn hơn người Kinh (17). Thứ hai, thanh niên Việt Nam không có kiến thức đầy đủ về sinh lý sức khoẻ sinh sản và bệnh lây truyền qua đường tình dục. So với người Kinh, họ cũng ít tiếp cận với dịch vụ chăm sóc sức khoẻ sinh sản có chất lượng do nhiều nguyên nhân như sống ở vùng sâu, rào cản ngôn ngữ, niềm tin vào phong tục tập quán (22). Hơn nữa, nguy cơ sức khoẻ sinh sản do kết hôn và trở thành cha mẹ sớm vẫn còn phổ 
biến trong nam, nữ thanh niên dân tộc thiểu số. Mặc dù tỷ lệ sinh tại nhà trong cả nước đã giảm, đẻ tại nhà của đồng bào dân tộc thiểu số sống ở vùng núi sâu vẫn còn phổ biến gây ra nhiều sự đe doạ cho sự an toàn của người mẹ (22).

Trong chương này chúng tôi mô tả sự khác nhau giữa các thế hệ và các dân tộc về quá trình đi đến kết hôn và trở thành cha mẹ của những thanh niên ở vùng nghiên cứu và ảnh hưởng của quá trình này đến sức khoẻ sinh sản và tình dục ${ }^{1}$. Đầu tiên, chúng tôi xem xét hành vi quan hệ trước giao hợp, sự khởi đầu của tình dục, lựa chọn bạn tình và tiếp cận với dịch vụ chăm sóc sức khoẻ sinh sản của những thanh niên chưa kết hôn. Chúng tôi cũng mô tả xu hướng tiến hành đám cưới, tỷ lệ kết hôn giữa các dân tộc, thời gian kết hôn và sinh con, nguyện vọng muốn có con trai ở địa điểm nghiên cứu. Ngoài ra, chúng tôi cũng quan tâm đến việc sử dụng và tiếp cận với kế hoạch hoá gia đình và dịch vụ chăm sóc sức khoẻ sinh sản.

\section{Khoảng thời gian kết hôn}

\subsection{Mối quan hệ nam nũ và hành vi trước giao hợp}

Trong vài năm qua, tình hình đường xá đã được cải thiện, số người có xe máy tăng lên làm cho việc đi lại dễ dàng hơn là một sự thay đổi rất có ý nghĩa ở làng nghiên cứu, đặc biệt là với thanh niên. Một tỷ lệ khá lớn dân số, đặc biệt là người Kinh đã đi ra ngoài làng để học tập và lao động. Ngược lại, những con đường mới đã giúp những người từ những nơi khác có điều kiện đến quan hệ với những người dân trong làng. Chúng tôi thấy việc đi lại tăng lên góp phần tác động đến những mối quan hệ trước hôn nhân đối với cả người Kinh và người dân tộc thiểu số. Những thế hệ trước, quan hệ nam nữ của thanh niên thường có sự giám sát chặt chẽ của cha mẹ hoặc những người lớn tuổi (trừ thời chiến tranh những nam thanh niên phải đi bộ đội), thường ít có những quan hệ với người bạn đời tương lai trước khi cưới. Thậm chí những người có mối quan hệ nam nữ trước hôn nhân, hành vi trước giao hợp chẳng hạn như cầm tay, hôn hay vuốt ve là rất hiếm. Việc tổ chức đám cưới giữa người Kinh và người dân tộc ở vùng nghiên cứu là rất phổ biến. Trích dẫn sau đây là một điển hình:

Thời gian tôi có thể đi chơi với chông của tôi - khi đó là bạn trai - là khi cả hai chúng tôi làm việc ở ngoài đồng. Chúng tôi không đi chơi riêng với nhau sau khi lao động. Chúng tôi không dám cầm tay nhau.

- Cơ, Nùng, nũu, 47 tuồi, có chồng, làng Al

\footnotetext{
Một số thanh niên, đặc biệt là phụ nữ đến các khu vực khác ngoài vùng nghiên cứu sau khi kết hôn. Một số ít thanh niên di cư đến vùng nghiên cứu và làm việc ở những nơi khác có thể trước đó đã kết hôn khi định cư ở nơi khác. Vì vậy, sự trải nghiệm quá trình dịch chuyển đến kết hôn và trở thành cha mẹ được mô tả trong chương này có thể là lựa chọn? Những kinh nghiệm của những người ít khi đi ra khỏi làng. Nữ thanh niên ở những vùng khác kết hôn với nam giới của địa phương và chuyển đến đây đều là những phụ nữ nông thôn.
} 
Bố me tôi và bố me chồng tôi chuẩn bị đám cưới. Chúng tôi chỉ nhìn thấy nhau vài lần trước khi cưới. Cha me chúng tôi sắp xếp mọi thứ cho chúng tôi. Chúng tôi đã không đồng ý với quyết định của họ... Hồi đó chúng tôi đã rất xấu hồ và không có kinh nghiệm nhu thanh niên bây giờ. Bây giờ khi con gái thích ai đấy, họ đến nhà người con trai đề tìm hiểu gia đình anh ta. Con gái thế hệ chúng tôi không làm nhu vậy. Chúng tôi chỉ đến nhà người con trai sau khi cưới. Nếu chúng tôi đến nhà trai trước đám cưới, mọi người sẽ hiểu rất xấu về người con gái.

- Vang, Kinh, nũ, 49 tuổi, đã có chông và 4 con, làng A2

Bây giờ người ta đi học nhiêu hơn, đi tìm hiểu nhau nên biết nhau. Ngày xua đường rậm mù ấy, đường rù̀ng có vắt đầy đầu nên chẳng có ai có bạn đi chơi mà tìm hiểu nhau đâu. Bây giờ có ôtô, xe máy nên dễ tìm hiểu lắm, còn đi lại với nhau đây.

- Phương, Dao, 29 tuổi, Làng Al

Nhờ có sự thay đổi nhanh chóng, thế hệ trẻ ngày nay ít trải qua sự kiểm soát của cha mẹ hơn và độc lập nhiều hơn trong việc tìm kiếm bạn tình và quan hệ nam nữ. Xu hướng này có ở cả người Kinh và người dân tộc. Thanh niên có nhiều cơ hội hơn trong việc dành thời gian riêng cho nhau mà không bị cha mẹ kiểm soát. Nắm tay giữa những cặp tình nhân chưa kết hôn là rất phổ biến. Mặc dù đã có những đôi bạn hôn và ôm nhau nhưng nhìn chung thanh niên ở đây cho rằng hành vi của họ trong quan hệ nam nữ chưa táo bạo, hiện đại và dễ dãi như bạn bè cùng lứa ở Đình Cả.

Nó đi nhiêu lắm cú hết anh này lại đến anh nọ. Chẳng biết yêu ai thật lòng. Nó là em gái họ, con cô ruột nhiều lúc em cũng muốn khuyên nhưng chưa có dịp.

- Hồng, Dao, 22 tuổi, làng A5

Chúng em chi ngồi bên bờ ruộng buổi tối để trò chuyện. Chúng em chỉ nói chuyện. Một số thanh niên có thể cầm tay hoặc hôn nhau. Nhưng em không thế. Ở vùng nông thôn này, chúng em không làm nhũng thứ như thanh niên thường làm ở thị trấn như cầm tay nhau đi trên đường phố.

- Thơ, Kinh, nũu, 22 tuổi, đã kết hôn, làng Al

Ở Đình Cả con trai và con gái yêu nhau luôn đi chơi với nhau. Họ tặng nhau nhũng món quà. Trong nhũ̃ng dịp đặc biệt các bạn trai thường đưa các bạn gái đến quán cafe. Ở vùng nông nông nhu làng của em thanh niên tán nhau chỉ là nói chuyện với nhau thôi. Rất đơn giản.

- Vân, Dao, nũu, 17 tuổi, học trường cấp III Đình Cả, làng A2

Phần lớn thanh niên tự chọn bạn của họ. Một số người gặp người bạn đời tương lai trong khi lao động hoặc khi đi học ở ngoài làng. Một số khác có sự hiểu biết sơ sơ về bạn khác giới thông qua lễ hội, chợ hay đám cưới. Ví dụ, nhiều người H'mong bắt đầu tìm hiểu nhau từ dịp Tết đầu năm mới. Con trai đi từ làng này đến làng khác với mục 
đích tham dự lễ hội và tìm bạn gái. Một dịp để làm quen với người bạn khác giới dịp năm mới là trò chơi tung còn ở lễ hội. Những chàng trai đứng thẳng hàng đối diện với những cô gái, tung quả còn đi và nhận quả còn ném lại. Trong những ngày này, con trai thường chú ý vào một cô gái. Trò chơi của năm mới là điều kiện tốt để quan hệ nam nữ có dịp nảy nở và phát triển. Thanh niên các dân tộc khác nhau đều nói rằng hiện nay, họ có nhiều cơ hội hơn để làm quen và tham gia vào các mối quan hệ nam nữ so với trước đây.

Bây giờ không có tục lệ làm mối hay rấm như trước nữa, em và chồng em quen nhau trong đám cưới anh trai em, chúng em tự tìm hiểu nhau và cưới thôi.

- Hoan, Kinh, 24 tuổi, đã kết hôn, làng A2

Em và vợ em sống cùng làng. Em đến nhà vợ em vì em biết anh trai cô ấy. Sau đó, em làm quen với cô ấy. Chúng em yêu nhau khoảng một năm thì cưới.

- Tài, Dao, nam, 26 tuổi, học hết lớp 5, cưới vọ người Dao, làng A1

Bây giờ người Kinh và người dân tộc gặp nhau dễ dàng. Nhiêu thanh niên người Kinh tù̀ làng khác đến làng chúng tôi (người Dao) bằng xe máy và tán tỉnh con gái. Họ thích con gái Dao vì con gái Dao luôn dịu dàng và không bướng bỉnh. Con gái Dao không cãi lại bố mẹ chồng nhu con gái người Kinh.

- Ty, Dao, nũu, 40 tuổi, đã kết hôn, làng A4

\subsection{Kiến thức về sức khoẻ sinh sản ở những người chưa kết hôn}

Mặc dù thanh niên có nhiều cơ hội để quan hệ nam nữ hoặc tán tỉnh để có quan hệ trước giao hợp và quan hệ tình dục, việc tiếp cận với kiến thức về sức khoẻ sinh sản của thanh niên khá hạn chế, đặc biệt với những thanh niên dân tộc thiểu số hoặc thanh niên người Kinh có học vấn thấp (thấp hơn trung học cơ sở). Tuổi dậy thì của thanh niên vùng nghiên cứu khá muộn, người dân tộc muộn hơn người Kinh. Thanh niên thường nói rằng dấu hiệu dậy thì đầu tiên của họ sau 15 tuổi. Nhiều người trong số họ không có kiến thức về tuổi dậy thì trước khi có dấu hiệu đầu tiên. Họ thường học về những thay đổi sinh lý này từ thầy cô, bạn bè, chị gái hoặc chương trình ti vi nhiều hơn là từ cha mẹ. Cha mẹ, đặc biệt những người có học vấn thấp thường tỏ ra lúng túng khi trao đổi về vấn đề dậy thì với con cái. Sau dấu hiệu dậy thì đầu tiên, nữ thanh niên thường được chỉ dẫn rằng họ có thể có thai nếu họ có hành động tình dục. Với một số người dân tộc thiểu số chẳng hạn như người Dao, thời gian dậy thì chứng tỏ họ đã sẫn sàng cho việc kết hôn và có gia đình.

Em mộng tinh lần đầu khi em 17-18 tuổi. Em không dám nói với gia đình hay bạn bè. Em hỏi họ về chuyện đó sau vài tháng.

- Đức, Kinh, nam, 22 tuổi, học hết lớp 5, đã kết hôn, làng A3

Em cảm thấy sợ hãi và lo lăng khi có kinh lần đầu. Em hỏi me em làm cái gì. Me em nói rằng đấy là chuyện bình thường ở con gái khi có kinh... Sau đó mẹ em dạy 
em làm gì ở lần tiếp theo. Me em dường như cũng lúng túng. Mẹ em nói sớm muộn rồi em cũng sẽ tự biết về nó một cách rõ ràng.

- Xía, H'mong, nũu, 20 tuổi, học sinh, làng B4

Không ai dạy em về tuổi dậy thì. Em học được điêu đó tù̀ nhũng chị gái của em khi em di chơi với họ... Me em không dạy em gì cả vì rất lúng túng. Em nghĩ nhũ̃ng chuyện này bọn trẻ phải tự học. Em cũng sẽ không nói với con em về chuyện đó.

- Thơ, Kinh, nữ, 22 tuổi, nông dân, đã kết hôn, làng A2

Trong quá trình nghiên cứu chúng tôi thấy việc thiếu nước sạch làm hạn chế thực hiện vệ sinh cá nhân. Nữ thanh niên cả dân tộc Kinh và dân tộc thiểu số chứng tỏ có kiến thức tốt về thực hiện vệ sinh trong kỳ kinh nguyệt. Phụ nữ sử dụng băng vệ sinh trong kỳ kinh nguyệt khá phổ biến và có thể dễ dàng mua ở chợ gần nhà hoặc những cửa hàng ở trong làng, đặc biệt là ở nhóm $\mathrm{B}$. Tuy nhiên tiền băng vệ sinh hàng tháng có thể là gánh nặng cho một số gia đình nghèo.

Em sử dụng băng vệ sinh trong kỳ kinh nguyệt. Em mua ở chộ. Nó khá đắt. Em phái tiết kiệm tiền để mua hàng tháng.

- De, H'mong, nũu, 17 tuổi, đã kết hôn có 1 con, làng B4

Kiến thức của họ về dậy thì rất hạn chế, hầu hết những thanh niên chưa có gia đình không có hiểu biết về tình dục an toàn, phương pháp kế hoạch hoá gia đình, HIV/AIDS và bệnh lây truyền qua đường tình dục. Phần lớn trong số họ được giáo dục tình dục ở trường hoặc qua tivi. Nữ thanh niên có vẻ thành thạo hơn nam về vấn đề này. Tuy nhiên, chưa dám chắc liệu kiến thức này có được thực hành trong đời sống khi nhiều người nói có nghe nói đến bao cao su nhưng không biết hình dạng như thế nào hay khi nào là thời kỳ an toàn. Đáng chú ý là người dân ở đây cho rằng kiến thức về sức khỏe tình dục và sinh sản chỉ cần thiết với những người có gia đình còn những người chưa có gia đình thì không cần phải quan tâm.

Trong trường của em, cô giáo không dạy chút nào là làm thế nào con gái lại có thai hoạc kế hoạch hoá gia đình là gì. Em nghe về bao cao su nhưng em không thể nói nhìn nó như thế nào. Em mới chỉ học về HIV gần đây qua tivi.

- Ước, Kinh, nũ, 19 tuổi, học hết lớp 9, làng A3

Em biết rất ít về sức khoẻ sinh sản. Em không biết những người phụ nũ đã kết hôn ở làng này đến đâu đề thực hiện phương pháp kế hoạch hoá gia đình. Em nghe một chút về điêu đó qua cô giáo ở trường học. Em nghĩ là sau khi kết hôn em có thế tìm hiểu thêm thông tin về điều này.

- Xía, H'mong, nũu, 21 tuổi, học lớp 12 ở Đình Cả, làng B4 


\subsection{Tình dục trước hôn nhân và tiếp cận với dịch vụ chăm sóc sức khoẻ sinh sản}

Trong nghiên cứu này, chúng tôi không cố gắng đo lường tỷ lệ quan hệ tình dục trước hôn nhân ở miền núi mà tìm hiểu hoàn cảnh ảnh hưởng đến những hành vi xã hội và hậu quả về sức khỏe. Quan hệ tình dục trước hôn nhân là mối quan tâm của cộng đồng vùng sâu vùng xa này, cả người già và thanh niên các dân tộc đều không dễ chấp nhận mối quan hệ này. Một số nhỏ thanh niên tỏ ra chấp nhận nếu những cặp tình nhân đó sẽ kết hôn.

Theo những người dân trong làng, vùng sâu vùng xa của họ đã hoà nhập với thế giới bên ngoài vì vậy họ có thể chịu tác động và tiếp nhận những suy nghĩ và đánh giá về hành vi tình dục của thanh niên chưa kết hôn bao gồm cả việc thực hành quan hệ tình dục trước hôn nhân từ thành thị. Thứ nhất, thanh niên ít phải trải qua sự kiểm soát của cha mẹ và thích tự cư xử theo cách của riêng mình hơn. Trong khi điều tra tại thực địa, một vài giai thoại nói tới đến một số thanh niên học trung học phổ thông (không thuộc vùng nghiên cứu) có quan hệ tình dục với nhiều bạn tình khi họ đi học ở Đình Cả. Hơn nữa, một số cha mẹ đổ lỗi hiện tượng này là do thông tin đại chúng, đặc biệt là những sách báo khiêu dâm du nhập vào vùng nghiên cứu.

Thời buổi này có rất nhiều phim ảnh khiêu dâm quanh đây. Nhũng người lớn phê phán loại phim này nhưng không ai cố gắng loại bỏ nó cả. Thanh niên ở đây rất trong sáng. Thanh niên ở đây có thể bị ấn tượng sai nếu xem những phim ảnh không trong sáng như thế này. Giáo dục về tình dục trước hôn nhân vẫn còn hạn chế ở vùng miền núi này. Những thứ mà thanh niên xem trên tivi có thể tác động không tốt đến thái độ của chúng về tình dục. Ngày nay cha mẹ rất khó để kiểm soát bọn tré.

- Nghĩa, Kinh, nam, 54 tuổi, cán bộ xã, làng Al

Hơn nữa, một số người trong làng cho rằng việc có sẵn các biện pháp tránh thai tăng lên chẳng hạn như bao cao su, thuốc tránh thai có thể góp phần làm gia tăng hành vi tình dục trước hôn nhân trong thanh niên. Nó được chứng minh qua trích dẫn sau:

Ngày nay thanh niên có thể sử dụng bao cao su hoặc uống thuốc tránh thai khi họ quan hệ tình duc. Cha me thậm chí còn không biết là ho có quan hệ tình dục. Ngay cả khi ho có thể tránh thai tôi nghĩ là điêu đó cũng vẫn không thể chấp nhận được. Tôi nghe nói thuốc tránh thai có thể có hại cho súc khoẻ phu nũ và nhũng bao cao su có chứa loại chất gì đó có hại. Quan trọng nhất là quan hệ trước hôn nhân làm mất danh giá của người phụ nũ.

- Lưu, Kinh, nũu, 55 tuổi, nông dân, làng A3

Trái ngược với nhận thức của một vài người, các phương pháp tránh thai hiện đại không có sã̃n cho những thanh niên chưa kết hôn ở vùng nghiên cứu. Những người đã 
từng sống ở đô thị tiếp cận với phương tiện tránh thai và các dịch vụ chăm sóc sức khoẻ sinh sản dễ dàng hơn những người chưa bao giờ rời khỏi ngôi làng của họ. Ở thời điểm hiện tại, phương tiện tránh thai cung cấp cho các cặp vợ chồng không thiếu (sẽ thảo luận ở phần tiếp theo), nhưng những người chưa kết hôn không dễ dàng có được sự cung cấp này, ngoại trừ những người có dịp đi ra ngoài làng của họ một cách thường xuyên. Bao cao su và thuốc tránh thai có thể mua ở các hiệu thuốc của địa phương. Tuy nhiên không có hiệu thuốc tư ở xã Phương Giao; xã Tràng Xá có một hiệu thuốc đặt ở trung tâm xã. Một số người Dao mua thuốc tránh thai và bao cao su ở chợ xã Bắc Sơn, tỉnh Lạng Sơn.

Cộng tác viên dân số phát bao cao su và thuốc tránh thai cho nhũng người đã có gia đình. Họ không phát cho nhũng người chưa cưới đâu.

- Phương, Dao, 29 tuổi, làng A4

Hội phu nũ phát bao cao su và thuốc tránh thai đấy. Khi cần thì đi mua ở chợ chú không đến đấy lấy đâu. Mình là con gái mà đi lấy bao cao su người ta sẽ cười mình.

- Hông, Dao, 25 tuổi, chưa kết hôn, làng A5

Cộng tác viên không nói về các biện pháp tránh thai với em đâu, họ chỉ nói với nhũ̃ng người đã có gia đình thôi...

- Vân, Kinh, 17 tuổi, chưa kết hôn, làng A2

\section{Khung 5.1. Có con ngoài giá thú và an ninh tuổi già}

Có thai trước hôn nhân và nạo phá thai đã xuất hiện ở địa điểm nghiên cúu. Điều thú vị đối với sụ kiện này là những người dân có những nhận thúc khác nhau phụ thuộc vào hoàn cảnh tùng người. Câu chuyện của Quy và Nga là ví dụ.

"Bà ấy đỉ ra ngoài, vui vẻ một chút và quay trở về nhà với đúa con bé bỏng." Đây là ý kiến của người trong làng nói về Quy một người phụ nữ có thai nhưng chưa có đám cưới.

Quy là phụ nữ người Dao gầy gò ở độ tuổi 40, trông bà rất khác với những người phụ nũ chơi bời và dễ dãi trong cuộc sống khác. Da tay của bà rám nắng, khuôn mặt đầy nếp nhăn cho thấy những năm tháng làm việc vất vả. Quy là người mẹ có hai con, chưa bao giờ kết hôn. Con gái lớn của bà 9 tuổi và con trai 2 tuổi. Bố của đúa con gái là người Kinh ở làng bên. Người làng nói rằng gia đình ông ta không đồng ý cho ông lấy bà vì bà là người Dao. Sáu năm sau, Quy có thai đúa con thú hai. Lần này bà có thai với người lái buôn trâu ở ngoài Phương Giao. Bà đã gặp may mắn. Bà có con trai.

Trong khi việc có con ngoài giá thú của Quy đã đem lại tiếng xấu cho phẩm hạnh của người phụ nũ Việt Nam, bà lại được những người trong làng 
chấp nhận. Bà vẫn được mời đi dụ đám cưới một việc được coi là sụ kiện quan trọng của cuộc sống trong làng. Bà hiếm khi tham dụ vì phải làm việc đồng áng vất vả. Bà Quy là trụ cột duy nhất trong gia đình phải chăm sóc 3 người khác- hai đúa con và một mẹ già.

"Rất may mắn là có con trai. Cuộc sống của bà ấy bây giờ dường như khó khăn nhưng khi con trai lớn lên nó sẽ chăm sóc bà ây lúc tuổi già"- người làng nói.

Theo hầu hết những người dân ở đây, an ninh tuổi già sẽ được đảm bảo nhờ những thành viên trong gia đình - đặc biệt là những đúa con (con trai). Niềm tin này phản ánh trong ước nguyện của bà Khanh có hai đúa con ngoài giá thú khi bà khoảng 30 tuổi.

"Hy vọng của tôi ngay bây giờ là hai đúa con gái lấy chồng bắt đầu cuộc sống gia đình riêng của chúng. Chỉ sau đó, tôi mới có thể yên tâm là chúng được chăm sóc”. Bà Khanh, bà mẹ người Dao ở độ tuổi 50 nói với giọng lo lắng.

Trong khi người làng rất thông cảm với những người phụ nũ độ tuổi 30 có con ngoài giá thú thì việc có thai trước hôn nhân ở những thanh niên trẻ hơn không được tán thành.

Nga, cô gái người Dao, ở cuối độ tuổi thiếu niên trong làng Na Bả là một thí dụ. Theo những câu chuyện phiếm của người làng, cô có thai nhưng cô đã nạo thai vì bạn trai không chịu cưới. Xấu hổ và lo cô ta không thể lấy chồng được nữa, bố mẹ cô ta cho cô đi Trung Quốc. Thay vì kiếm việc làm cô đã bị bán cho một người đàn ông ở miền Nam Trung Quốc. Nga chưa bao giờ quay trở về và gia đình cô đã rất buồn khi nói về việc mất cô con gái này.

Phù hợp với xu hướng tình dục trước hôn nhân, việc có thai trước hôn nhân cũng tăng lên- cho thấy có lẽ thanh niên không đủ kiến thức và ít có điều kiện tiếp cận với các biện pháp tránh thai. Nữ thanh niên thường chịu hậu quả của quan hệ tình dục trước hôn nhân và bị đánh giá nhiều hơn so với nam giới. Họ bị phê phán nhiều hơn nam giới vì bị coi là mất tư cách. Nói một cách khác, nam giới được khoan dung hơn về hành động quan hệ tình dục trước hôn nhân:

Nếu người phu nũ có thai trước đám cưới, mọi người sẽ khinh bi vì quá dễ dãi hay quá mất mát. Nếu người bạn tình của cô ta tù chối cưới cô ta và không có trách nhiệm chăm sóc thi tương lai của cô ta có thể rất bi đát. Không ai muốn cưới cô ta cả.

- Thơ, Kinh, nũu, 22 tuổi, nông dân, làng A2

Với những thanh niên vẫn còn đang đi học (thường trung học phổ thông), có thai trước hôn nhân luôn làm cho việc học hành bị gián đoạn. Họ thường phải bỏ học để làm mẹ. Một số nói rằng có những phụ nữ chưa kết hôn phải nạo phá thai. Hầu hết 
những phụ nữ có thai trước hôn nhân ở vùng nghiên cứu phải tổ chức đám cưới vội vàng. Đôi khi việc này gây ra nhiều rắc rối trong gia đình.

Em con cô của em có thai trước khi cưới. Bố mẹ cô ấy đã rất tức giận vì danh tiếng của gia đình cô ây có nguy cơ bị mất. Cô em đã nói rằng hai đứa nó có lỗi. Chỉ có một cách để giữ danh tiếng của cô ta và cho cả hai nhà là làm đám cưới càng nhanh càng tốt. Họ đã phải tổ chức đám cưới khi cô ấy có thai được 2-3 tháng.

- Tình, Kinh, Nam, 28 tuổi, đã kết hôn, học hết lớp 5, nông dân, làng A3

Hai đứa bạn người Dao của em đã có thai trước khi cưới. Cuối cùng thì ho cũng đã tổ chức đám cưới. Ho khá may măn. Nếu người phụ nũ mà không được cưới thì tương lai của họ sê rất đáng thương.

- Khải, Tày, nam, 25 tuổi, cán bộ xãa, làng Al

Thật ngạc nhiên, chúng tôi không tìm được bất kỳ bằng chứng nào ủng hộ việc quan hệ tình dục trước hôn nhân khi nhiều người coi đó như một khuynh hướng văn hoá ở người H'mong. Nói một cách khác, người H'mong không cho phép quan hệ tình dục trước hôn nhân như người Kinh và Dao. Chỉ có một người đàn ông ở độ tuổi 40 từ làng $\mathrm{B} 4$ đã nói một cách cởi mở về hành vi tình dục trước hôn nhân của anh ta khi chúng tôi làm việc tại địa phương. Những người H'mong khác cả thế hệ già và trẻ dường như có thái độ che giấu hành vi tình dục trước hôn nhân. Trong khi chợ tình của người H'mong phổ biến ở những điểm du lịch của Việt Nam như Sapa (tỉnh Lào Cai) là nơi để thanh niên tự do tìm hiểu thì loại hình này không có ở vùng nghiên cứu. Hơn nữa, hành vi "cướp vợ" tức là người phụ nữ bị người đàn ông kết hôn không cần sự đồng ý của người phụ nữ cũng rất hiếm ở những làng trong địa điểm nghiên cứu. Nhiều người $\mathrm{H}^{\prime}$ mong nhìn nhận hành động này như là hành động lạc hậu và xúc phạm đến danh dự của cha mẹ.

\section{Kết hôn}

\subsection{Thòi gian kết hôn}

Kết hôn được xem là sự kiện quan trọng nhất trong cuộc đời của thanh niên

trong vùng nghiên cứu. Khi thanh niên kết hôn và bắt đầu cuộc sống gia đình riêng (như khi có một con) họ được coi như là một người trưởng thành hoàn toàn - có lẽ việc này có ý nghĩa còn quan trọng hơn việc bỏ học hay trở thành một công nhân chuyên nghiệp. Trích dẫn sau là của một nông dân người Dao từ làng A5 nói về con trai 20 tuổi của anh ta.

Tôi muốn con trai của tôi sẽ lấy vợ vào năm sau vì vậy nó phải học cách chịu trách nhiệm. Khi nó có gia đình riêng, nó sẽ thuần thục nhu một người trưởng thành. Nó đã bỏ học 2 năm nay nhưng bây giờ tôi chưa thấy nó làm việc nghiêm chinh. 
Đám cưới thường diễn ra sớm. Điều tra dân số trong làng năm 2005 cung cấp số liệu mô tả cắt ngang cho thấy sự khác nhau về thời gian đám cưới giữa các dân tộc. Hình 9 mô tả tỷ lệ những người dân đã kết hôn theo tuổi, giới và dân tộc.

\section{Hinh 9. Tỷ lệ kết hôn theo giới và dân tộc}

Tỷ lệ

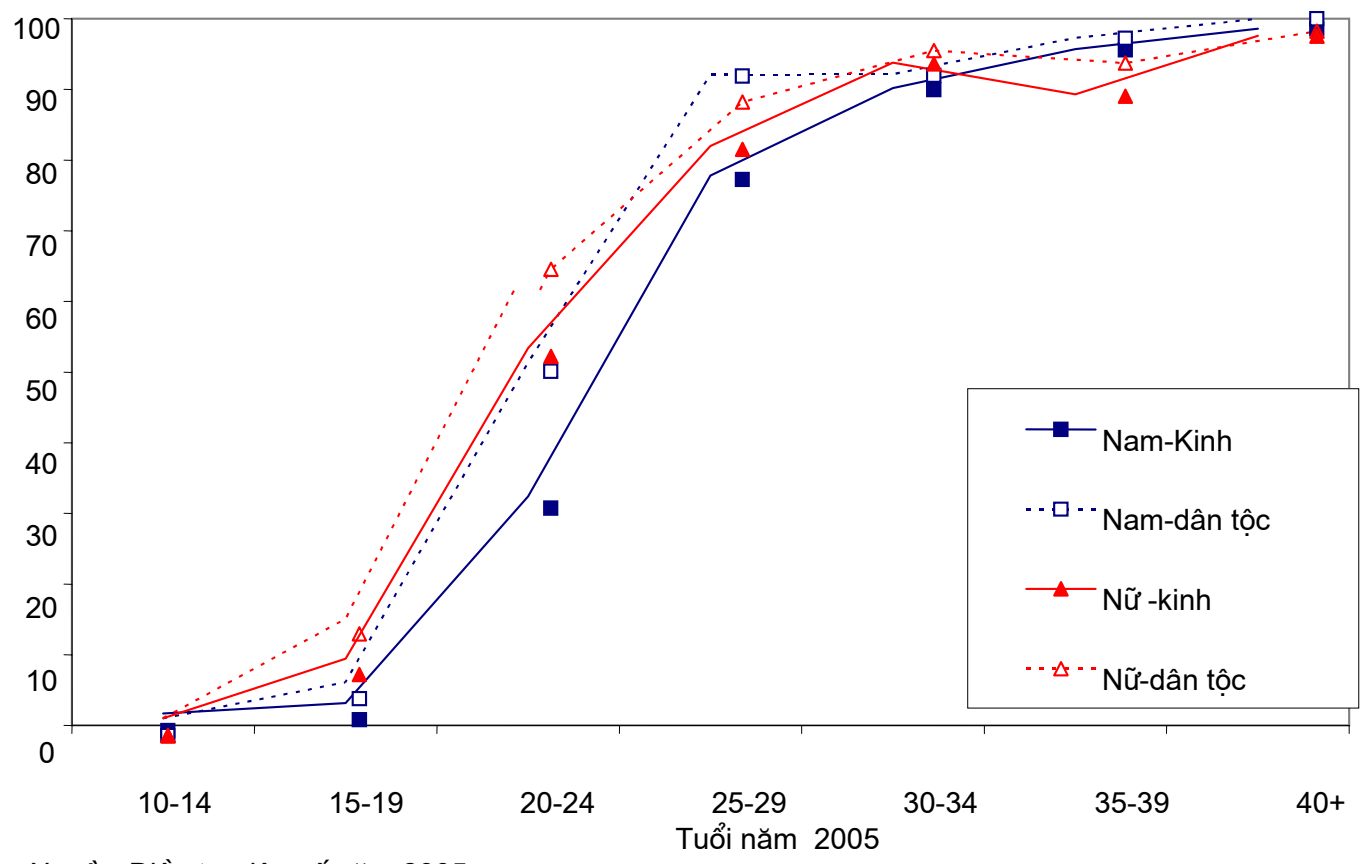

Nguồn: Điều tra dân số năm 2005

Bảng 13. Tŷ̉ lệ kết hôn theo giới và dân tộc

\begin{tabular}{|c|c|c|c|c|}
\hline Tuổi & $\begin{array}{c}\text { Nam - Kinh } \\
(\%)\end{array}$ & $\begin{array}{c}\text { Nam - Dân tộc } \\
(\%)\end{array}$ & $\begin{array}{c}\text { Nữ - Kinh } \\
(\%)\end{array}$ & $\begin{array}{c}\text { Nũ - Dân tộc } \\
(\%)\end{array}$ \\
\hline $10-14$ & 1.7 & 1.0 & 1.0 & 1.0 \\
\hline $15-19$ & 3.2 & 6.1 & 9.4 & 15.1 \\
\hline $20-24$ & 32.4 & 51.3 & 53.4 & 65.4 \\
\hline $25-29$ & 77.8 & 92.1 & 82.0 & 88.5 \\
\hline $30-34$ & 90.2 & 92.2 & 93.8 & 95.6 \\
\hline $35-39$ & 95.7 & 97.3 & 89.3 & 93.9 \\
\hline $40+$ & 98.6 & 100.0 & 97.6 & 98.3 \\
\hline
\end{tabular}

Kết quả cho thấy nữ thường cưới sớm hơn nam. Điều này đúng ở cả người Kinh và người dân tộc. Năm 2005, hơn một nửa phụ nữ người Kinh từ 20-24 tuổi chưa cưới, chỉ có $1 / 3$ nam giới cưới vợ. Dân tộc thiểu số kết hôn sớm hơn người Kinh. Tỷ lệ người dân tộc cưới ở độ tuổi 20-24 là $65 \%$ ở nữ giới và $50 \%$ ở nam giới. Điều làm chúng tôi 
ngạc nhiên là hiện tượng thiếu niên kết hôn vẫn tồn tại ở cộng đồng nhưng tỷ lệ những người từ 10 đến 19 tuổi kết hôn khá thấp, đặc biệt là nam giới và người Kinh. Kết quả cho thấy đến lứa tuổi 30 phần lớn người dân các dân tộc, cả nam và nữ đã kết hôn.

Hình 10. Tỷ lệ đã kết hôn: so sánh người Kinh nhóm $A$ và $B$

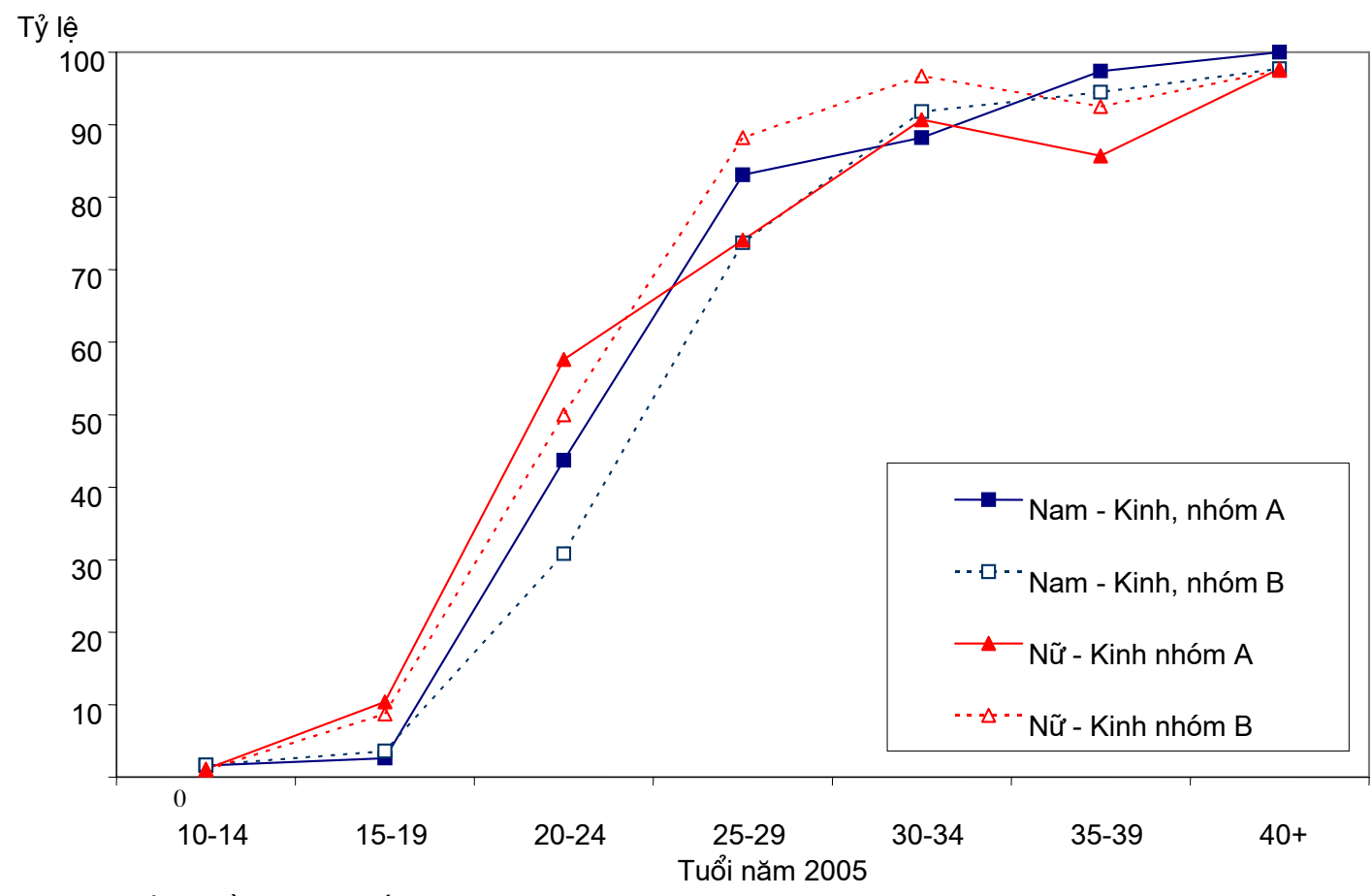

Nguồn : Điều tra dân số 2005

Hình 10 đánh giá mô hình thời gian kết hôn của người Kinh nhóm $\mathrm{A}$ và $\mathrm{B}$. Như đã nói tới ở chương 3 , nhóm $\mathrm{B}$ có điều kiện kinh tế - xã hội phát triển hơn nhóm $\mathrm{A}$. Điều này giải thích tại sao thanh niên nhóm $\mathrm{B}$ kết hôn muộn hơn nhóm $\mathrm{A}$. Ví dụ, 30\% nam và 50\% nữ ở độ tuổi 20 đến 24 nhóm $\mathrm{B}$ đã kết hôn. Trong khi đó, trên $40 \%$ nam và $60 \%$ nữ nhóm A kết hôn ở độ tuổi này. Hiện tượng thanh thiếu niên người Kinh (15-19) kết hôn sớm không phổ biến ở cả 2 nhóm nghiên cứu. 


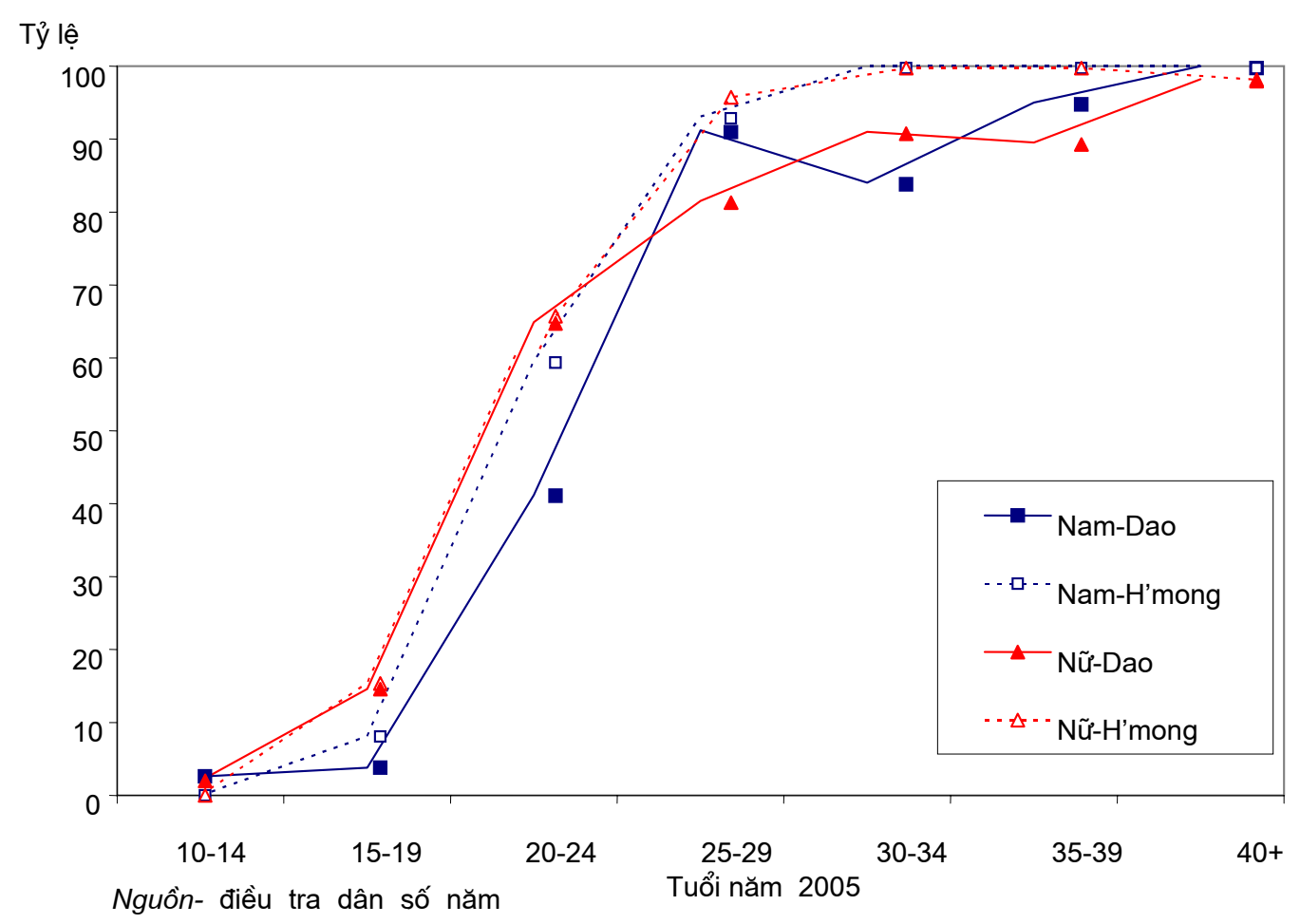

Trong khi sự khác nhau về độ tuổi kết hôn của người Kinh ở vùng nghiên cứu (hình 10) khá khiêm tốn, hình 11 chỉ ra mô hình thú vị về sự khác nhau của độ tuổi kết hôn giữa giới và dân tộc của người Kinh và Dao. Không như người Kinh, cưới tuổi thanh thiếu niên vẫn còn phổ biến ở người Dao và H'mong, đặc biệt là nữ giới. Điều tra dân số năm 2005 cho thấy $15 \%$ phụ nữ từ 15-19 tuổi đã kết hôn. Tỷ lệ phụ nữ người Dao từ 20-24 tuổi kết hôn là cao nhất (65\%); tuy nhiên, kết quả cho thấy sự khác nhau giữa nữ người $\mathrm{H}$ 'mong và người Dao ở độ tuổi 25 . Gần như tất cả $(96 \%)$ người H'mong độ tuổi 25-29 đã có chồng. Tuy nhiên, chúng tôi quan sát thấy có sự trì hoãn đám cưới ở một số phụ nữ người Dao ở 3 nhóm tuổi 25-29, 30-34, và 35-39 tuổi. Chúng tôi nghi ngờ về biểu hiện này do lỗi báo cáo hoặc yếu tố nhiễu. Ví dụ, chúng tôi đã gặp một phụ nữ người Dao 29 tuổi, theo báo cáo dân số người phụ nữ này chưa có chồng, nhưng sau đó chúng tôi biết được qua người hàng xóm của cô ta là cô đã có chồng trong thời gian ngắn. Sau khi ly dị, cô ta trở về nhà bố mẹ và chưa tái hôn.

Nhìn chung, đàn ông H'mong cưới vợ sớm hơn đàn ông người Dao. 60\% nam giới người H'mong cưới vợ ở độ tuổi 20-24, trong khi đó nam giới người Dao là $40 \%$. So sánh cả nhóm, tỷ lệ kết hôn của người Dao thấp hơn người H'mong cùng độ tuổi. Nam giới người H'mong cưới muộn hơn nữ giới; tuy thế, sự khác nhau dường như là rất ít. 
Trước tuổi 30, hầu hết nam và nữ người H'mong đều đã kết hôn. Không giống người H'mong, nam nữ người Dao có sự khác nhau đáng kể về độ tuổi kết hôn. Với nhóm thanh thiếu niên dưới 20 tuổi, tỷ lệ nam giới người Dao đã kết hôn thấp hơn nữ. Có tỷ lệ nhỏ kết hôn ở nhóm nam giới người Dao từ 30-34 tuổi cần được điều tra sâu hơn nữa.

Bảng 14. So sánh tỷ lệ kết hôn giữa người Dao và H'mong

\begin{tabular}{|c|c|c|c|c|}
\hline Tuổi & $\begin{array}{c}\text { Nam-Người Dao } \\
(\%)\end{array}$ & $\begin{array}{c}\text { Nam-Người H'mong } \\
(\%)\end{array}$ & $\begin{array}{c}\text { Nứ-Người Dao } \\
(\%)\end{array}$ & $\begin{array}{c}\text { Nứ-Người H'mong } \\
(\%)\end{array}$ \\
\hline $10-14$ & 2.6 & 0.0 & 2.0 & 0.0 \\
\hline $15-19$ & 3.8 & 8.1 & 14.6 & 15.4 \\
\hline $20-24$ & 41.2 & 59.5 & 64.9 & 65.9 \\
\hline $25-29$ & 91.2 & 93.1 & 81.5 & 96.0 \\
\hline $30-34$ & 84.0 & 100.0 & 91.0 & 100.0 \\
\hline $35-39$ & 95.0 & 100.0 & 89.5 & 100.0 \\
\hline $40+$ & 100.0 & 100.0 & 98.2 & 98.4 \\
\hline
\end{tabular}

Điều tra dân số không cho phép đánh giá sự thay đổi tuổi kết hôn trung bình theo thời gian (qua nhóm ngày sinh). Tuy nhiên, phỏng vấn sâu thanh niên và gia đình thấy có xu hướng trì hoãn thời gian cưới của tất cả các dân tộc trong vùng nghiên cứu, đặc biệt với thanh niên người Kinh. Với thế hệ cha mẹ, phụ nữ người Kinh thường cưới sau tuổi thanh thiếu niên; người $\mathrm{H}^{\prime}$ mong và Dao, ở giữa tuổi thanh thiếu niên. Nam giới người Kinh và dân tộc thiểu số thường cưới vào đầu độ tuổi 20 (nam người H'mong sớm hơn một chút). Một số người đàn ông trì hoãn đám cưới vì họ gia nhập quân đội trong thời gian chiến tranh ở Việt Nam.

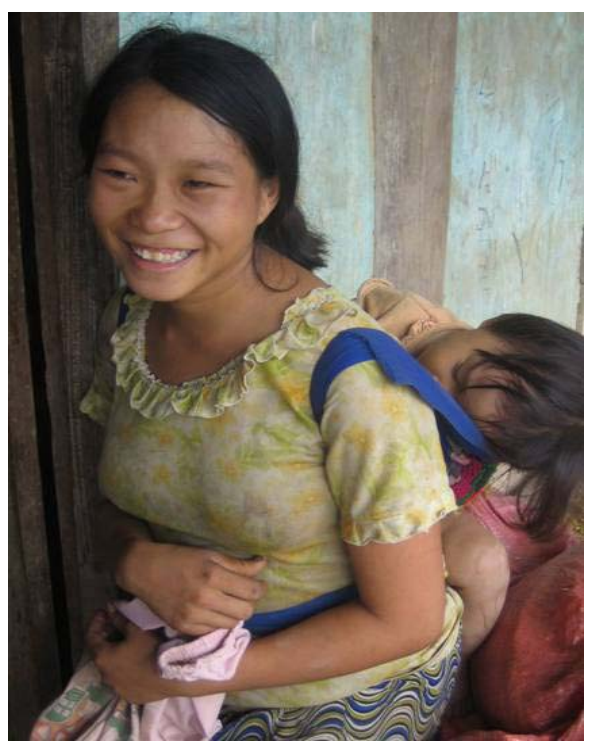

dinh 16. Thanh niên ngày nay tổ chức Tám cưới muộn hơn cha mẹ, đặe biệt lì nquiòi Xinh và nhüng nquiời có họe vấn ít nhất hết trung họe cơ sở. Xết hôn sớm vẫn còn ờ người $\mathscr{H}^{\prime}$ mong và nquiòi Dao. Mquiòi mẹ Dao này cuiới truiớc 17 tuối, bây giờ cồ tang ở tầu độ tuối 20 wà đang mang thai đúa con thú hai. 
Nhìn chung, thanh niên ngày nay cưới muộn hơn cha mẹ, đặc biệt là người Kinh và những người ít nhất đã học hết trung học cơ sở. Cưới sớm vẫn còn xảy ra ở một số người Dao và H'mong nghèo, những người có học vấn thấp hoặc không đi học, người có ít sự hiểu biết bên ngoài làng của họ.

Em cưới khi 18 tuổi. Lúc đó em không thích cưới. Bố mẹ em cứ nói em cưới vì nhà em nghèo. Nhà chồng em có nhiều đất để cho em trồng ngô. Khi em 14 tuổi đã có người hỏi em làm vợ nhưng em tù̀ chôí. Đến khi em 18 tuổi, bố me em nói em aủ tuổi để đi lấy chồng. Vì thế em đã cưới.

- Phương, Dao, nũu, 29 tuổi, đã kết hôn có 3 con, làng A4

Tất cả con gái ở đây không đi học hoặc hiếm khi đi ra khỏi làng thường cưới khi 17-18 tuổi. Với nhũ̃ng người đi học hoặc đi làm thì cưới muộn hơn. Một số nam giới thi có thể đợi đến khi 30 tuổi.

- Vang, Kinh, nũu, 49 tuổi, đã kết hôn có 4 con, làng A2

Tuổi được luật pháp cho phép kết hôn ở Việt Nam là 18 ở nữ và 20 ở nam², nhiều thanh niên ở vùng nghiên cứu nghĩ rằng thời gian kết hôn nên sau tuổi 20. Nam giới thường kết hôn muộn hơn nữ giới. Cùng từ suy nghĩ của họ về độ tuổi kết hôn, thanh niên thường cho rằng cá nhân nên tự chủ khi đã sang tuổi kết hôn. Những điều kiện này bao gồm học xong, đủ trưởng thành và có nghề nghiệp, thu nhập ổn định.

Tuổi kết hôn em nghĩ khoảng 22 tuổi. Ở tuổi đó, một cô gái trưởng thành đầy đủ sẽ trở thành người vợ, người mẹ, người con dâu tốt.

- Ước, Kinh, nũu, 19 tuổi, học hết lớp 9, nông dân, làng A3

Em nghĩ em sẽ kết hôn khi được 25-26 tuổi. Điều quan trọng là em phải có nghê ổn định trước. Em cảm thấy thất vọng với nhũ̃ng người con gái H'mong cưới chông quá sớm. Như em được biết, thanh niên chưa có nghề nghiệp ổn định cho đến khi it nhất họ được 22 tuổi. Nhưng hầu hết con gái làng em cưới khi 17-18 tuổi. Chắc là ho sẽ sống ở đây phần đời còn lại. Làm thế nào để có thể chuyển đến nơi khác để làm việc khi mà ho đã có gia đình và con cái.

- Xía, H'mong, nũu, 21 tuổi, học lớp 12 ở Đình Cả, làng B4

Tính trung bình, phụ nữ người Kinh ở vùng nghiên cứu kết hôn muộn hơn phụ nữ dân tộc thiểu số, điều đó được phản ánh qua trích dẫn sau đây:

Con gái người Kinh cưới muộn hơn. Nhiều người trong số họ chỉ cưới khi đã 2324 tuổi. Con gái người H'mong thì cưới sớm hơn nhiều. Nếu ai đó trong số bọn

2 Trong những năm vừa qua, nhiều cặp nam nữ đã cưới trước tuổi luật pháp cho phép. Một số trì hoãn việc đăng ký kết hôn đến khi họ đủ 18 hoặc 20 tuổi; một số khác thì khai tuổi sai khi họ đi đăng ký kết hôn. Tuy nhiên rất khó để có thể làm cho hợp pháp vì sổ hộ khẩu đã ghi rõ ngày sinh của họ và họ được yêu cầu phải trình sổ hộ khẩu khi đi đăng ký kết hôn. 
em 20 tuổi mà chưa có gia đình, sẽ bi nghĩ là ế chông. Trái lại người Kinh 20 tuổi vẫn còn đang lựa chọn.

- Danh, H'mong, nũu, 21 tuổi, đã kết hôn có 1 con, làng B4

Với người Kinh, ở độ tuổi trước hoặc giữa 20 tuổi, có quan niệm đã thành phụ nữ để kết hôn, khi họ trì hoãn kết hôn đến sau tuổi 20 hoặc 30 luôn gây ra nhiều lo lắng cho người mẹ và gia đình họ, đặc biệt là những phụ nữ đang làm nông nghiệp. Cha mẹ bày tỏ mối lo lắng về tương lai của con gái họ, đặc biệt lo lắng sự đảm bảo cho tuổi già. Tuy nhiên, dường như cha mẹ lo lắng ít hơn nếu con gái có học vấn cao hơn và có thể có nghề nghiệp với thu nhập từ đồng lương ổn định.

Tôi nghĩ rằng chẳng có vấn đề gì cho con gái tôi khi nó vẫn chưa có gia đình đến tận 30 tuổi, nếu nhu nó có nghề nghiệp tốt. Cuộc sống sẽ phức tạp hơn nếu nó cưới chồng sớm như tôi. Cha me ở vùng này muốn con gái cưới chồng sớmkhoảng 14-15 tuổi. Nhưng tôi không cân biết người khác làm như thế nào. Tôi không cần phải theo họ.

- De, H'mong, nũu, 54 tuổi, có 12 con, làng B4

\subsection{Kết hôn giữa các dân tộc}

Phần lớn thanh niên thế hệ hiện nay ở vùng nghiên cứu có quyền tự do lựa chọn bạn đời. Tình yêu lãng mạn thường được đặt ra như là một tiêu chí quan trọng cho người Kinh cưới những người dân tộc khác khi chọn vợ hoặc chồng. Hơn nữa, thanh niên thường thích người bạn đời có cùng điều kiện kinh tế. Cả nam và nữ thuộc hộ nghèo, chú trọng việc họ lấy ai đó cũng nghèo như mình hơn là lấy những người giàu hơn vì họ không muốn bị gia đình chồng/vợ coi thường. Ngoài ra, trình độ học vấn cũng là tiêu chí để lựa chọn bạn đời. Nam thanh niên thích cưới ai đó có trình độ học vấn thấp hơn hoặc như mình. Trong khi đó, những người phụ nữ tìm kiếm những người có học vấn ngang bằng hoặc cao hơn. Tính cách cá nhân cũng được cho là yếu tố quan trọng. Nam giới thường bày tỏ họ thích những người vợ làm việc chăm chỉ, dịu dàng, trái lại nữ giới thích người chồng tương lai của họ không nghiện rượu. Dân tộc vẫn là tiêu chí quan trọng để lựa chọn người bạn đời. Nhưng theo nhiều người trẻ ở vùng nghiên cứu, vấn đề cùng dân tộc không còn quan trọng như thế hệ cha mẹ họ. Ý kiến sau đây khá điển hình:

Khi tôi còn trẻ, mọi thứ đêu rất khác. Mọi người chỉ cưới người cùng dân tộc. Nếu tôi muốn cưới vợ không phải là dân tộc Kinh, bố me của tôi sẽ không đồng ý. Bây giờ mọi thư đã thay đổi. Không sao cả khi lấy người dân tộc khác. Bây giờ các dân tộc đêu ngang hàng như nhau. Không có sự phân biệt đối xử về dân tộc ở đây. - Hoan, Kinh, nam, 59 tuổi, một con trai đã lấy người Tày, làng A2 
Em không thấy có vấn đề gì khi hai người ở hai nhóm dân tộc cưới nhau. Em nghĩ bây giờ mọi người ngang nhau. Mọi người có thể cưới ai mà người ta thích không tính đến dân tộc.

- Ngàn, Kinh, nũu, 21 tuổi, chưa cưới, làng A2

Ngày xưa em cũng hơ mặc cảm, sợ không xưng đáng nên không dám đáp lại tình yêu của chông em, ngày xua mà. Nhưng sau đó chúng em vấn yêu nhau.

- Xuân, Dao, 26 tuổi, lấy chồng người Kinh, làng A3

Như đã nêu ở trên những trích dẫn đưa ra một bức tranh lạc quan. Quả thực đám cưới giữa các dân tộc ngày nay phổ biến hơn. Tuy nhiên xu hướng này có giới hạn ở người Kinh, Tày và Nùng. Trong nghiên cứu này, xu hướng kết hôn trong 3 nhóm dân tộc có sự tương đồng về kinh tế - xã hội và sự hoà hợp về văn hoá diễn ra nhiều hơn. Đám cưới giữa người Kinh với người H'mong và người Dao ít phổ biến hơn.

Có rất nhiêu đám cưới giữa người Kinh với người Tày và Nùng. Mối quan hệ của họ rất tốt. Với nhũng nhóm dân tộc khác, họ không có quan hệ tốt với người Kinh.

- Trương xóm, Kinh, làng B2, nhóm B

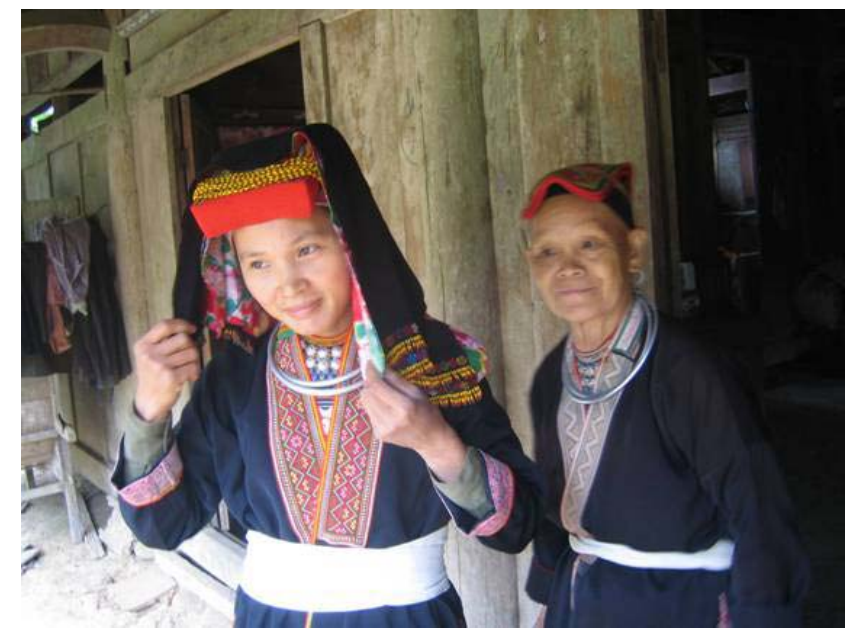

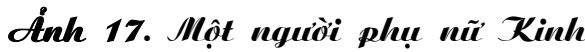
lî̀n đầu tiên mặe quần áo Dao trong Tời. Câ ta lấy chồng người Dao ờ làng At4 đự̛̣e 6 măm. Mlẹ chồng ciua cồ vất vui khi uhìn thấy con dâu trong bộ quần áo nquiời Dao.

Trong vài năm vừa qua, số lượng người Kinh và Dao lấy nhau tăng lên ở hầu hết các làng nghiên cứu ở nhóm $\mathrm{A}$ (ngoại trừ làng xa nhất, làng $\mathrm{A} 5$ ). Trong những năm tới đây xu hướng tương tự vẫn diễn ra ở nhóm $\mathrm{B}$ nơi có làng người H'mong. Xét sự tương quan các yếu tố, có thể giải thích tại sao đám cưới người Kinh với người H'mong và Dao lại ít phổ biến hơn. Thứ nhất, trong khi hầu hết thanh niên dân tộc Dao, H'mong hiểu được tiếng Kinh và chỉ nói được chút ít, nhưng ngôn ngữ chính của họ vẫn là tiếng dân tộc thì người Tày và Nùng sử dụng tiếng Kinh như tiếng mẹ đẻ. Khi rào cản ngôn ngữ xuất hiện sẽ tạo ra sự hạn chế trong hòa nhập về mặt xã hội, tác động đến khả năng có thể phát triển những mối quan hệ lãng mạn. 
Ở làng của em cha mẹ không còn bắt buộc con cái phải cưới người cùng dân tộc nũa. Tuy nhiên, em nghĩ là em cưới người Dao thì vấn tốt hơn bởi vì chúng em vẫn nói tiếng Dao và có thể hiểu nhau hơn.

- Hồng, Dao, nũ 25 tuổi, chưa kết hôn, làng A5

Ngoài vấn đề ngôn ngữ, một số còn đề cập đến sự khác nhau về văn hoá và lối sống giữa người Kinh, Dao và H'mong là một yếu tố cản trở kết hôn giữa các dân tộc trong vùng nghiên cứu. Điều này đặc biệt đúng với người Kinh và Dao. Ví dụ, có tin đồn lan truyền trong làng người Kinh là người Dao có khả năng đặt bùa những người họ không thích và thầy phù thuỷ người Dao có khả năng liên lạc với những người ở thế giới bên kia. Vì những tin đồn này mà thế hệ người Kinh đã già không cho bọn trẻ kết bạn hoặc có những mối quan hệ nam nữ với người Dao. Về phía người Dao, họ muốn duy trì hoạt động văn hoá thờ những người thân thông qua thầy phù thuỷ, vì vậy họ thích cưới người cùng dân tộc. Điều này được phản ánh trong trích dẫn sau đây:

Tôi thích con gái của tôi lấy người Dao, những người Dao chúng tôi thờ người thân nhờ thây phù thuỷ. Nếu con gái tôi cưới một người khác dân tộc, khi người ấy không tin và không làm như vậy con gái tôi phải bỏ tập quán này.

- Khanh, Dao, nũ̃, 52 tuổi, đã kết hôn, làng A5.

Một người đàn ông khác dân tộc cũng được nhưng em thích lấy người Dao. Nếu em cưới người khác dân tộc em sợ gia đình chông tương lai của em có thể không hiểu phong tuc của bọn em. Ví dụ, trong ngày lễ tết, chúng em luôn mời thây phù thuỷ đến nhà để cúng tổ tiên. Em sợ những người khác có thể không thích loại phong tục tập quán này.

- Hà, Dao, nũu, 16 tuổi, chưa kết hôn, làng A5

Một yếu tố khác góp phần làm cho tỷ lệ đám cưới giữa người Kinh, Dao và H'mong thấp là do vốn hiểu biết về xã hội và con người thấp hơn ở hai dân tộc thiểu sốđặc biệt khi điều kiện kinh tế và xã hội là hai tiêu chí quan trọng để lựa chọn bạn đời. Trong khi thanh niên người Kinh, Dao và H'mong vui vẻ tiếp nhận quan niệm cưới người khác dân tộc, khoảng cách dân tộc khá rộng về giáo dục và tài sản của gia đình đã đặt ra sự so sánh giữa người Kinh và người bạn dân tộc thiểu số của họ.

\section{Khung 5.2: Cuộc sống kết hôn giữa các dân tộc}

Những thế hệ trước đây, đám cưới với người dân tộc khác, đặc biệt là giữa người Kinh và người Dao hầu nhu không có. Trong vài năm qua, có sụ tăng lên một cách chậm chạp những đám cưới giữa thanh niên nam nũ của hai dân tộc này. Sụ khác nhau về ngôn ngữ, tập quán, điều kiện kinh tế, giáo dục đưa ra câu hỏi để so sánh. Chỉ một số nhỏ thanh niên nam và nữ quyết định chống lại những suy nghĩ này. 
Thảo phụ nữ người Kinh 26 tuổi, học hết trung học phổ thông ở xã Tràng Xá đã cưới một nông dân người Dao làng A2. Cô kể lại việc gia đình cô đã phản úng khi cô quyết định cưới như sau: "Bố mẹ tôi chẳng nói gì cả. Họ đồng ý để tôi và chồng tôi lấy nhau. Chỉ có ông tôi phản đối quyết định đám cưới. Ông tôi hỏi tôi tại sao lại lấy chồng người Dao khi tôi có học vấn cao. Ông tôi bảo tôi không lấy chồng và tiếp tục đi học. Nhưng tôi đã không có tiền để đi học tiếp. Tôi quyết định lấy chồng..."

Thảo đã hạnh phúc với cuộc sống sau kết hôn. Cô có con năm 2006. Điều quan trọng là chồng cô có học vấn thấp hơn cô nhưng làm ăn khá tốt ở làng A2 và khá gần gũi với tộp quán của người Kinh. Bố chồng Thảo là cựu chiến binh đã có thời gian dài sống ở ngoài làng và mẹ chồng cô là người Kinh. Hầu hết những cọ̆p vợ chồng khác dân tộc không được may mắn như Thảo. Những người vợ luôn phái sống với gia đình nhà chồng sau đám cưới. Vì vộy, những người phụ nũ này luôn phải chịu gánh nọ̆ng điều chỉnh cách sống sao cho phù hợp với gia đình nhà chồng.

Tôi nói với con dâu của tôi là phải theo lối sống của chúng tôi. Tôi nói với nó phải học tiếng Kinh vì nó sống ở nhà của chúng tôi với vai trò là con dâu. Nó dường như không gặp khó khăn gì trong việc điều chỉnh để phù hợp với cuộc sống của chúng tôi.

- Chao, Kinh, nữ, 45 tuổi, con trai lấy vợ người Dao

Anh trai tôi lấy vợ người Dao. Chị dâu tôi lúc đầu rất xấu hổ. Chị ấy nói rằng người Kinh nói nhiều hơn người Dao. Chị ấy lúng túng vì công cụ sản xuất của nhà chúng tôi khác nhà chị ấy. Chị ấy phải khó khăn lắm mới sư dụng được.

-uớc, Kinh, nũ, 19 tuổi, có anh trai lấy vọ người Dao

Con dâu tôi là người Kinh, nó tốt nhưng chậm chạp. Nó không khoẻ như phụ nữ người Dao. Nó chỉ biết ít tiếng Dao.

- Nảy, Dao,nũ, 75 tuổi, có con trai út lấy vọ người Kinh

Trong quá trình làm việc tại cộng đồng chúng tôi nhận thấy chỉ một số rất nhỏ cặp vợ chồng Kinh và Dao đã ly dị hoặc ly thân. Do sự hạn chế của số liệu, chúng tôi không thể kết luận đám cưới các cặp vợ chồng giữa các dân tộc khác nhau thì dễ tan vỡ hơn những đám cưới của các cặp vợ chồng cùng dân tộc.

\subsection{Nhũ̃ng thay đổi về thực hành đám cưới}

Khi kinh tế của vùng nghiên cứu phát triển nhanh chóng trong những năm vừa qua, phần lớn các hộ gia đình đã chứng kiến mức độ thu nhập tăng lên chưa từng có so 
với trước đây. Một phần của tài sản kiếm được này sẽ chi cho đám cưới của các thành viên trong gia đình - một trong những sự kiện quan trọng của cuộc sống trong làng. Người dân hoàn toàn đồng ý với nhận xét đám cưới trở nên phong phú hơn so với đám cưới trước đây. Điều này đặc biệt đúng đối với đám cưới người Dao và H'mong. Những người dân thế hệ trước nhớ lại đám cưới của họ như sau:

Đám cưới của tôi rất đơn giản. Cha mẹ thông báo chúng tôi một ngày tốt cho đám cưới. Vào ngày đó, tôi đón vợ tôi tù̀ nhà cô ấy. Tất cả chỉ có thế. Tôi không mặc áo cưới nhu bây giờ. Chúng tôi không thuê ai chup ảnh cả.

- Hoan, Kinh, nam, 59 tuổi, đã kết hôn, làng A2

Chúng tôi không có cỗ cưới. Chúng tôi chỉ đi đến uỷ ban nhân dân để có giấy chứng nhận kết hôn. Chúng tôi quá nghèo không có tiền để chi vào cỗ cưới.

- Tiên, Dao, nam, 49 tuổi, nông dân, làng Al

Trong vùng nghiên cứu, đám cưới do sự sắp xếp của hai bên gia đình. Trong khi thanh niên có quyền tự do lựa chọn bạn đời, cha mẹ của cô dâu và chú rể vẫn quyết định hầu hết các công việc trong tổ chức đám cưới, bao gồm lựa chọn ngày cưới, đàm phán về lễ vật và chi phí cho cỗ cưới. Sau khi cặp thanh niên quyết định lấy nhau, họ thông báo với cha mẹ. Gia đình nhà trai sẽ đến nhà gái lần đầu tiên và chính thức ăn hỏi. Sau đó là quá trình đàm phán về ngày cưới và lễ cưới. Sau khi đạt được sự thoả thuận, kế hoạch về lễ cưới sẽ được thông báo đến họ hàng và những người dân khác trong làng. Đám cưới luôn được tổ chức vào cuối các vụ thu hoạch khoảng tháng 11,12 hoặc tháng 1. Lễ cưới được tổ chức trong vòng từ hai đến bốn ngày. Cỗ cưới luôn được tổ chức riêng ở nhà cô dâu và chú rể, mặc dù họ ở trong cùng một làng. Sau khi cỗ cưới được tổ chức ở nhà cô dâu, chú rể, những người đi đón dâu sẽ đến nhà cô dâu và đón cô dâu về nhà chú rể. Một cỗ cưới khác được tổ chức tại nhà chú rể sau đó.

\section{Khung 5.3: Câu chuyện đám cưới người Dao}

Tiếng nhạc ồn ào từ hai loa đại trong một buổi sáng mùa đông ở làng A4. Một sự lựa chọn các loại nhạc hỗn độn trong đám cưới-chỉ đám cưới người Dao. Những người dụ đám cưới dường nhu không hiểu và không quan tâm nhạc điệu tiếng Anh có nghĩa là gì nhưng họ có nhiều thời gian. Nhạc rock ầm i nhưng những điểm cơ bán của đám cưới người Dao vẫn còn nguyên vẹn.

Đám cưới có lẽ là sụ kiện quan trọng nhất trong cuộc sống của người Dao. Nó là biểu tượng người Dao đã đến tuổi kết hôn sắp đóng vai trò làm vợ/chồng và sớm trở thành cha mẹ. Sụ chú ý của mọi người đến đám cưới phụ thuộc vào vị trí cha mẹ trong cộng đồng. Mọi người cũng thể hiện sụ quan tâm chia vui bằng cách giúp đỡ những người tổ chúc cưới bằng tiền hoặc một loại vật phẩm gì đó. 
Hơn hai chục người tập trung ở nhà của Vang để giúp chuẩn bị tiệc cưới của con trai anh. Có khoảng 200 đến 300 khách đến dụ nên gia đình cần nhiều người đến giúp. Một văi thanh niên nam ngồi cạnh con suối nhỏ cháy qua nhà Vang. Họ tán gẫu và vặt lông gà giúp để làm cỗ đãi khách. Một số người khác bận rộn trang trí cổng rạp đám cưới nơi cô dâu, chú rể chuẩn bị đi qua để bước vào rạp đám cưới. Phụ nũ thịt gà và chuẩn bị những đĩa rau và thịt. Một người thầy cúng lúi húi một mình trong góc vườn đang cúng tổ tiên với đĩa thịt, gạo và rượ. Sau vài phút ông ta đốt tiền và vàng để mời nhũng người thế giới bên kia đến ăn cỗ và phù hộ cho cọ̆p vợ chồng trẻ.

Không phải tất cả mọi người đều bận bịu vì công việc. Một số đàn ông trung niên ngồi vòng quanh trong ngôi nhà của Vang. Họ uống rượu, cười, tán gẫu rất to bằng tiếng Dao. Một số ît đã say khi mới có 9h sáng và tiệc cưới còn chưa bắt đầu. Thời gian đó, bọn trẻ con chạy loanh quanh, vãi người phụ nữ độ tuổi 30 tranh thủ co hội tập đi xe máy. Nhiều người xem và cười với người phụ nữ cố gắng đi xe máy - tài sản mới nhất của gia đình cô.

Gần đây chỉ vài nhà có thể cố gắng mua được xe máy. Đây là loại phương tiện hiện đại cùng với những con đường mới kết nối với thế giới bên ngoài, tạo cơ hội cho những thanh niên, đặc biệt thanh niên dân tộc thiểu số có học vấn thấp gặp được những tiềm năng bên ngoài cộng đồng của họ. Ví dụ nhu trường hợp của Phúc- con trai ông Vang và Nga - người sớm trở thành vợ của anh, đến tù làng Dân Tiến gần đó.

Phúc mới bắt đầu sang tuổi 20 và Nga - người Dao mới 19 tuổi. Như nhiều cọ̆p tình nhân thế hệ này, họ quen nhau mà không có sụ giám sát của cha mẹ. Thục ra họ chỉ hỏi cha mẹ cho phép kết hôn khi họ quyết định lấy nhau. Bố của Phúc đến nhà Nga ở Dân Tiến để hỏi ý kiến gia đình Nga. Bố mẹ Nga đồng ý và thách cưới. Không biết chính xác số lượng lễ vật nhà Nga đòi là bao nhiêu, thách cưới ở làng người Dao thường tù 2 đến 6 triệu đồng, 80 kg thịt và rượ. Sau khi thương lượng, ngày tốt cho lễ cưới được lụa chọn. Khách mời sẽ là tất cả mọi gia đình trong làng và họ hàng, bạn bè tù nơi khác đến.

"Đám cưới là lúc hạnh phúc nhất. Bạn sẽ muốn chia sẻ niềm hạnh phúc lớn lao này với gia đình và bạn bè”. Đó là lời giải thích của người Dao về việc tại sao đám cưới lại rất lớn, có ít nhất đến hàng trăm khách.

Đám cưới của Phúc và Nga được tổ chúc trong 2 ngày. Ngày đầu tiên cỗ cưới được tổ chúc ở nhà Nga để kỷ niệm quá trình đi đến kết hôn của cô và cũng là cơ hội cho cô và gia đình có bũa cơm tạm biệt trước khi cô đến sống ở gia đình chồng. Ngày thú hai, một nhóm người tù gia đình Phúc đến nhà Nga tù sáng sớm để đón cô về nhà anh. Cỗ cưới ngày thú hai tổ chúc ở nhà chú rể. Không giống như người Kinh, chú rể người Dao tên Phúc không tụ đi đón cô 
dâu về nhà mình.

Cảm ơn rất nhiều những con đường tốt và những chiếc xe máy của người dân trong làng, việc đón cô dâu chỉ trong vòng buổi sáng. Một đoàn người hơn 10 chiếc xe máy đã đến làng A4 vào khoảng 10h sáng đón Nga, đồ đạc của cô và quà đám cưới. Mẹ Nga và những người bạn đưa cô đến nơi ở mới mà Nga sớm gọi đó là nhà mình.

Cô dâu trẻ và những người đi theo dưng ở giữa đường trước khi đến cổng nhà chú rể. Những chiếc chiếu được trải ra đường để làm chỗ trang điểm cho cô dâu. Nga đã mặc tất cả 4 bộ quần áo Dao. Theo phong tục của người Dao, mặc càng nhiều quần áo của người Dao càng đẹp. Nhiều nhất một người có thể mặc đến 15 bộ, mỗi bộ giá khoảng 400.000 đồng. Thêm vào đó $\mathrm{Nga}$ cũng vấn khăn đen theo trang phục của người Dao. Cô trang điểm nhẹ nhàng.

Nhạc rock vẫn được nghe thấy tù phía xa. Nga rất lo lắng. Hơn 30 người mà hầu hết trong số họ là xa lạ đang nhìn Nga trang điểm. Cỗ cưới cũng bắt đầu và có thể kéo dài hơn hai tiếng sau đó. Hành trình của Nga đến ngôi nhà mới ở làng A4 đã bắt đầu.

Thách cưới đã tăng lên vùn vụt trong các thập kỷ qua. Trước đây, người ta thách 80-100 kg thịt, gạo, và rượu. Nhà cô dâu không yêu cầu tiền mặt. Ngày nay, cả gia đình người Kinh và dân tộc thiểu số có thể thách tiền mặt hoặc tiền mặt và quà truyền thống - điều này phụ thuộc vào điều kiện kinh tế của cả hai gia đình. Tiền mặt có thể từ hàng trăm nghìn đến vài triệu đồng. Ở vùng nghiên cứu, người Dao và H'mong thách cưới cao hơn người Kinh. Số lượng đôi khi có thể nhiều hơn thu nhập bình quân hàng năm của hộ gia đình. Một bà mẹ người Dao rất thích thú giải thích lý do tại sao lại thách cưới cao như sau:

Tôi đòi 6 triệu tiền mặt. Tôi dành phần lớn tiền cho việc mua nhũng đồ cân thiết cho con gái tôi trước khi nó về nhà chông. Tôi mua cho nó một đôi khuyên tai, một dây chuyền, đôi chăn và quần áo mới. Nó có nhiều đồ nên phải có 3 - 4 xe máy chở đồ về nhà cho nó. Sau khi mua tất cả quà nhu vậy, chúng tôi chỉ còn lại vài trăm để chi tiêu. Chúng tôi biết là chúng tôi thách cưới nhiêu nhưng chúng tôi dành hâu hết số tiền đó cho con gái tôi. Chúng tôi nghĩ là con gái chúng tôi cần có nhũ̃ng tài sản giá trị như thế khi đến nhà mới.

- Ty, Dao, nũu, 40 tuổi, làng A4

Cùng với những đồ đạc phong phú cho con gái, nhiều gia đình có thể chi số lượng đáng kể vào trang phục của cô dâu. Những bộ quần áo công phu trở thành một phần quan trọng của đám cưới ngày nay. Trước đây người Kinh mặc những bộ quần áo mới trong ngày cưới. Ngày nay nhiều cô dâu thích mặc những bộ váy cưới kiểu phương Tây. 
Những bộ váy áo này có thể thuê với giá hàng trăm ngàn đồng từ cửa hàng áo cưới ở Đình Cả. Những cô dâu người Kinh có số tiền ít hơn có thể mặc bộ áo dài truyền thống. Cùng với thuê những bộ quần áo, họ thường phải thuê trang điểm và chải tóc. Như thế hệ cha mẹ của họ, cô dâu người Dao và H'mong vẫn mặc những bộ quần áo truyền thống trong ngày cưới. Tuy nhiên những bộ quần áo trong ngày cưới cực kỳ đẹp và được may thêu công phu. Quần áo cưới của người H'mong và Dao không thể thuê. Gia đình cô dâu phải đi mua hoặc tự may. Một số gia đình người Dao và $\mathrm{H}$ 'mong nói rằng họ phải chi 2 triệu đồng chỉ cho những bộ quần áo cưới.

Cả bộ quân áo cưới bao gồm áo và váy giá trên một triệu đồng. Bố mẹ em nghèo lắm vì vậy không thể cố gắng để mua quần áo cưới cho em. Em phải tự may lấy.

- Chợ, H'mong, nũu, 24 tuổi, đã kết hôn, làng B4

Chúng tôi thuê người may quần áo cưới cho con gái tôi. Chúng tôi quá bận rộn với công việc đồng áng nên không có thời gian để tự may quân áo. Mỗi cái áo người Dao rất đắt bởi vì phải sủ dụng nhũ̃ng nguyên liệu đặc biệt và đắt. Với nhũ̃ng đồ phu trợ giá là 150.000 đông và phân thêu ở dưới mất thêm 150. 000 đồng. Cho cả bộ quần áo mất khoảng gần 400.000 đồng. Con gái của tôi có 10 bộ trong ngày cưới. Cô dâu mặc càng nhiều bộ trong ngày cưới nhìn cô ta càng xinh. Mất rất nhiêu tiên. Tôi không muốn nghĩ đến điều đó. Tôi chỉ có một cô con gái. Tôi muốn làm tốt nhất cho nó. Hàng xóm sẽ chê cười nếu tôi keo kiệt với đám cưới của con gái tôi... Mặc nhũ̃ng bộ quần áo Dao đẹp nhu thế này có nghĩa chúng tôi kính trọng tổ tiên. Nếu con gái tôi không mặc áo Dao, nhũng hôn ma của tổ tiên sẽ chê cười chúng tôi và nhạo báng chúng tôi vì không phô bày giá trị của người Dao.

- Vân, Dao, nư, 47 tuổi, làng A4

Với những đám cưới giữa người Kinh và người dân tộc, cặp thanh niên luôn luôn theo nguyên tắc ăn mặc của người Kinh trong ngày cưới. Một phụ nữ người Kinh ở làng A1 cưới người Dao đưa ra lời giải thích như sau:

Tôi không bị yêu cầu mặc quần áo Dao trong ngày cưới. Chỉ có chông của tôi mặc quần áo Dao để cúng tổ tiên của anh ây. Khi tôi không mặc quần áo Dao, bố me chồng tôi không bắt tôi vái tổ tiên hoặc mặc quân áo Dao.

- Thơ, Kinh, nũu, 22 tuổi, kết hôn có hai con, làng Al

Theo những người dân trong làng, những bữa cỗ đông người là phần không thể thiếu được trong đám cưới ở vùng nghiên cứu. Trước đây, tổ chức tiệc cưới không yêu cầu đông người. Nếu có tổ chức thì tiệc cưới thường nhỏ và chỉ đơn giản là đĩa kẹo và nước chè. Tuy nhiên ngày nay cả nhà trai và nhà gái đều tổ chức tiệc lớn không chỉ mời những người họ hàng mà còn mời cả người dân trong làng. Vì điều kiện đường xá tốt hơn và việc đi lại thuận lợi, khách mời của họ có thể bao gồm cả gia đình và bạn bè ở vùng khác của huyện Võ Nhai hoặc từ tỉnh khác. Số lượng khách mời có thể từ 200 đến 600 người. Những gia đình người Dao và H'mong nói tiệc cưới của họ to hơn người 
Kinh, họ là những người thích tổ chức cỗ cưới tuỳ theo điều kiện kinh tế. Với sự gắn bó trong cộng đồng như ở những làng nghiên cứu, người dân cho rằng có nhiều áp lực để tổ chức đám cưới lớn thậm chí cả khi điều kiện kinh tế của họ không sã̃n sàng vì đây đã như thành tục lệ mới.

Đầu tiên em muốn có đám cưới nhỏ. Nhưng cuối cùng thì em phải làm theo nhũng gì mà người khác thường làm. Em cảm thấy thật bối rối nếu chỉ tiếp khách bằng kẹo và nước chè trong khi nhũng người khác tiếp khách của ho bằng nhũng bữa tiệc lớn. Em nghe thấy cũng có những người khác trong làng muốn tổ chức đám cưới nhỏ. Nhưng không ai dám làm như vậy. Bây giờ phong tục ở đây là có bũa tiệc cưới to.

- Thơ, Kinh, nũu, 22 tuổi, nhà nghèo, làng Al

Trong bũa tiệc cưới to, khách được tiếp nhũng dĩa thịt gà ngon và rượu. Theo tập quán của người Dao, chúng tôi phải mời tất cả mọi người mình biết đến dụ đám cưới của gia dình. Nếu chúng tôi không làm như thế, họ sẽ cười chúng tôi và nói rằng chúng tôi tham lam và keo kiệt. Tù̀ khi chúng tôi đi đến nhũng đám cưới khác trước đây, chúng tôi phải mời ho đến dư khi chúng tôi tổ chức đám cưới cho một trong nhũ̃ng đứa con của tôi. Đó là cách đáp lại sự quý mến của họ.

- Ty, Dao, nũu, 40 tuổi, làng A4

Thường có nhiều chi phí liên quan đến tổ chức đám cưới ở đây, bao gồm lễ ăn hỏi, lễ cưới, quần áo cưới, bữa tiệc lớn đến những khoản chi khác. Mặc dù có tục lệ khách sẽ mừng một chút tiền cho chủ nhà nhưng số tiền này không đủ để chi trả cho mọi thứ. Hầu hết các gia đình, đặc biệt nhà trai ở vùng nghiên cứu luôn bị dẫn đến cảnh nợ nần sau đám cưới. Số tiền nợ có thể từ vài trăm ngàn đồng đến 3 triệu đồng hoặc nhiều hơn thế. Tiền thường được vay từ họ hàng và bạn bè. Một số người dân nói rằng tiền tổ chức đám cưới còn có thể được vay từ chương trình tín dụng có sẫn cho những xã có chương trình 135 để phát triển nông nghiệp. Ngoài tiền mặt, một số gia đình có thể vay lợn, gạo, rượu từ hàng xóm hoặc bạn bè của họ.

Tôi không vay chút tiên mặt nào cho đám cưới của con trai tôi. Tôi chỉ vay họ hàng một ít gạo. Tôi đã sủ dụng 130 lít rượu và 100 kg thịt lợn cho cỗ cưới. Tôi đã mua $70 \mathrm{~kg}$ thịt lợn và vay $30 \mathrm{~kg}$ còn lại của con gái của tôi. Tôi chưa trả lại nó. Tôi chỉ cần trả nó khi nó cần dùng thịt lợn. Chúng tôi sử dụng quà là tiền mặt nhận tù̀ khách để trả tiền thịt. Chúng tôi vẫn còn nợ người họ hàng gạo.

- Vinh, Nùng, nư, 47 tuổi, làng Al

Hầu hết người dân luôn không có bất kỳ sự lo lắng nào về nợ nần đám cưới mà phải mất vài năm gia đình mới trả hết. Cha mẹ luôn có trách nhiệm trả nợ; tuy thế, cặp vợ chồng trẻ thường đóng góp giúp đỡ. Trong vùng nghiên cứu, những cặp vợ chồng mới thường sống với gia đình chồng ngay sau khi cưới. Vì thế, nếu họ lao động trên đất canh tác của gia đình, họ đóng góp luôn vào thu nhập của gia đình. Có một số nhỏ 
trong vùng nghiên cứu, đặc biệt giữa những làng người Kinh, khuyến khích những gia đình này tổ chức đám cưới nhỏ trong điều kiện kinh tế gia đình và khuyến khích gia đình cô dâu thách cưới với mức trung bình. Ví dụ, xã Phương Giao có sự thoả thuận về thách cưới tiêu chuẩn chỉ 80kg thịt và 400 ngàn đồng. Một vài gia đình nói rằng họ đã thách cưới thấp hơn mức này vì họ nhận ra rằng nếu gia đình chú rể nợ nhiều do đám cưới, con gái của họ phải làm việc vất vả để trả món nợ này.

\section{Sau kết hôn}

\subsection{Sắp xếp cuộc sống sau kết hôn}

Ngay sau đám cưới, cặp vợ chồng trẻ sẽ sống ở nhà bố mẹ chồng ít nhất vài năm đầu. Mô hình này có ở cả người Kinh và người dân tộc. Theo mô hình cuộc sống này, thanh niên làm việc ở đất canh tác gia đình nhà chồng. Thu nhập có được từ việc bán các sản phẩm nông nghiệp được để chung và gia đình nhà chồng sẽ quản lý. Trong khi phần lớn các cặp vợ chồng tre chấp nhận sự sắp xếp này mà không có tranh cãi trong gia đình, một số cặp vợ chồng trẻ phàn nàn về vấn đề đi lại tự do trong gia đình họ. Tuy nhiên, mô hình sắp xếp cuộc sống này đã bị phá vỡ trong vài năm vừa qua khi kinh tế hộ gia đình xuất hiện và khi các cặp vợ chồng mới cưới có một người mà hầu hết là người chồng di cư đi làm ở ngoài làng hoặc đi làm thuê hàng ngày.

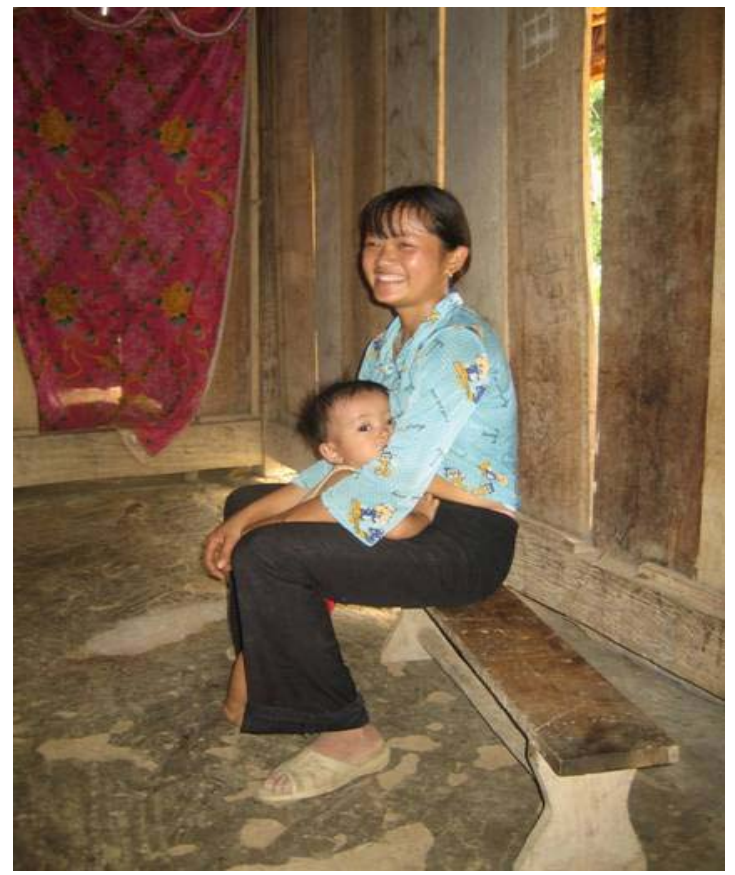

dinh 18. Dhụ nũ ngưò̀i Dao 17 tuối và đúa con 1 tuồi. Chồng cô đã đi Malaysia để lại cồ ở uhà oới gia đinh chồng.

Những cặp vợ chồng luôn được cha mẹ chồng cho phép rời khỏi gia đình và làm nhà riêng sau khi sinh đứa con đầu lòng. Tuỳ thuộc vào điều kiện kinh tế của gia đình, 
bố mẹ của chồng hoặc vợ có thể hỗ trợ một chút tài sản chẳng hạn như mảnh đất hay con trâu. Một số cặp vợ chồng may mắn, gia đình thông gia có thể giúp xây nhà cho họ. Khi cặp vợ chồng không sống cùng gia đình nhà chồng nữa, họ độc lập để quản lý các sản phẩm nông nghiệp và thu nhập. Đôi khi họ cũng phải tự lo những món nợ của họ.

Theo ý kiến tôi, tôi nghĩ rằng cặp vợ chồng trẻ nên làm nhà riêng trong thời gian ngắn sau khi kết hôn. Ho vẫn còn trẻ và có thể khó khăn khi họ trồng cấy các loại cây trồng và bán các sản phẩm. Nhưng ho nên làm như vạy. Con trai của tôi, Việt, tôi giúp đỡ nó bằng cách dụng cho nó một cái nhà.

- Vit, Kinh, nam, 64 tuổi, trưởng xã về huu, làng B4

Chúng tôi không sống cùng cha mẹ sau khi cưới không lâu. Bố mẹ chồng tôi nghèo và gia đình quá đông người sông trong nhà đó. Bố me chồng tôi không cho chúng tôi gì cả. Bố mẹ tôi cho mảnh đất để sống và it đất để trồng trọt. Tù khi chúng tôi ra ở riêng, chúng tôi phải lo trả nợ những khoản tù đám cưới. Sau khi cưới 8 năm, chúng tôi vẫn chuia trả được hết số nợ đó.

- Xuân, Dao, nũu, 31 tuổi, nông dân, làng Al

Với những hộ nghèo hoặc có ít đất đai, làm một ngôi nhà riêng cho cặp vợ chồng mới là điều không thể. Những cách khác có thể được sử dụng để quản lý kinh tế gia đình. Vợ chồng Huệ là một ví dụ. Họ đã cưới gần được 5 năm và vẫn ở chung với bố mẹ chồng. Bố mẹ chồng cô ta chỉ có mảnh vườn nhỏ cũng là mảnh đất canh tác. Đôi vợ chồng này không thể có đất để làm nhà riêng. Bố mẹ chồng phải chia một phần mảnh đất nhỏ của họ cho vợ chồng Huệ. Trong khi sống cùng dưới một mái nhà và ăn chung với bố mẹ chồng, cặp vợ chồng này tự quản lý thu nhập của họ từ việc có tiền bán các sản phẩm riêng của họ độc lập với phần còn lại của gia đình.

\subsection{Mong muốn sinh con}

Các cặp vợ chồng người Kinh và người dân tộc thiểu số luôn có con sau khi cưới 1 hoặc 2 năm. Khoảng thời gian sinh con đầu lòng luôn ngắn vì những cặp vợ chồng mới cưới không chú ý thực hiện việc thực hiện kế hoạch sinh đẻ. Tỷ lệ sinh giảm xuống có ý nghĩa trong những thập kỷ vừa qua, đặc biệt là người Kinh ở nhóm $\mathrm{A}$ và $\mathrm{B}$ sinh ít hơn người H'mong và Dao. Hầu hết những người từ 15 đến 29 tuổi chúng tôi phỏng vấn, đều có ít nhất 4-5 anh chị em, nhưng hầu hết họ đều không muốn có trên hai con. Người ta mong muốn có quy mô gia đình nhỏ hơn thế hệ cha mẹ có lẽ vì nhiều người đã phải trải qua đói nghèo và đang chịu những áp lực về đất đai.

Vợ chông em chỉ dư kiến có 1 con. Chúng em đã có một con trai. Vợ em nói nêu chúng em có hai con thì rất khó khăn vì chúng em không có đủ đất đai để cho chúng khi chúng lớn lên.

- Thanh, Dao, nam, 26 tuổi, học hết lớp 5, làng A2 

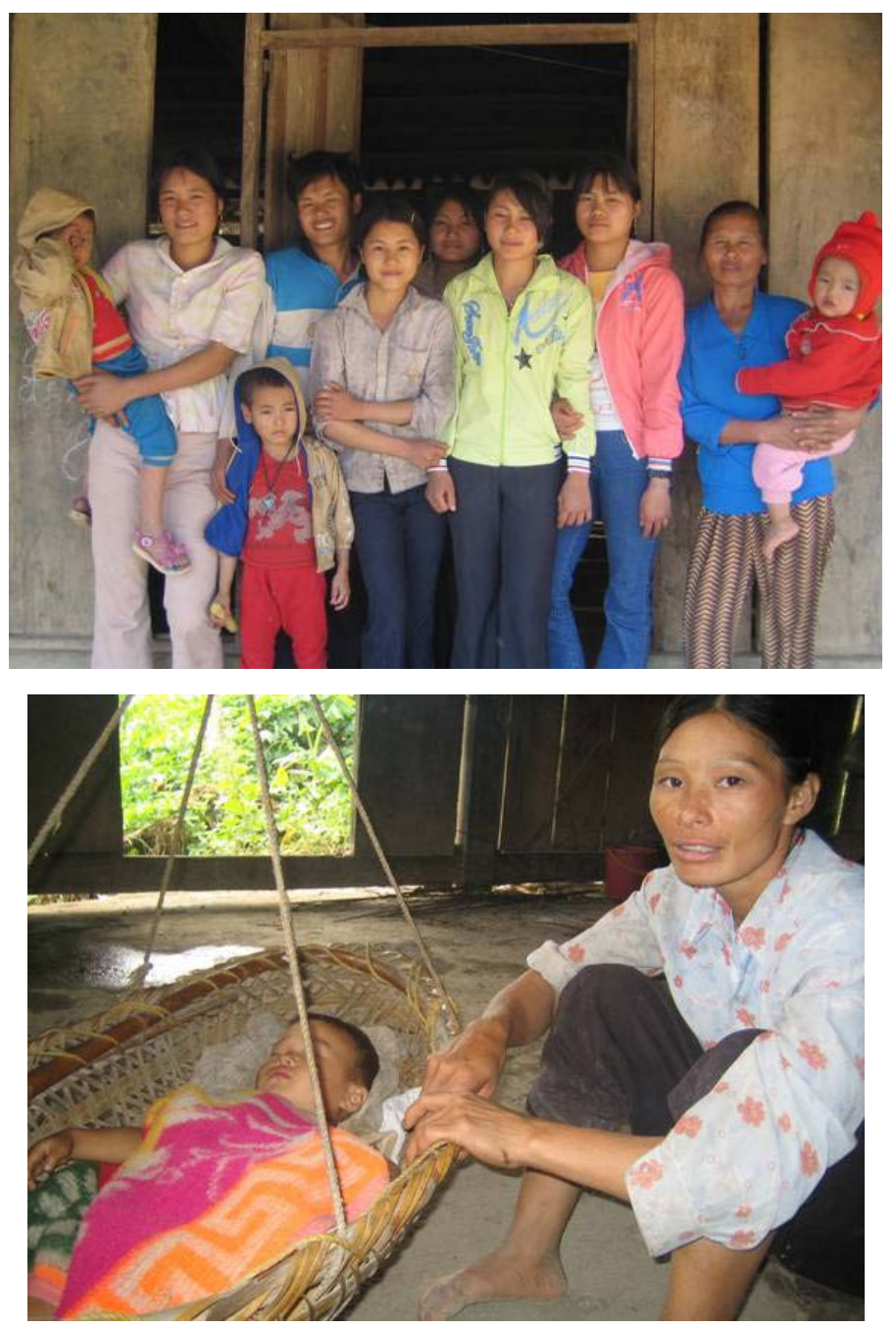

dink 19. dink chup tai gia tiunk nguò̀i $\mathscr{C}^{\prime}$ mong ở làng A4. Mlột người me làm việe vất vả (tuíng thú hai bên phaii) có 14 túa con tù 2 tến 25 tuồi. Grong khi hầu hết thank miên lớn lên với $4-5$ ank chị em, rất nhiều nquời trong số họ không muốn có uhiều hơn hai con.

dink 20. Mguiòi me nquiòi Dao wà con ở làng A5. Q̂̀ đã eó chồng wới ba túa con qái đầu, cô đã nói với điều tra viên và̀ng sẽ có thêm con nếu tứa theí tu' không phải là con trai.

Mặc dù mong muốn có hai con là rất rõ ràng, một số lượng đáng kể thanh niên ở vùng nghiên cứu vẫn không thể đạt được quy mô gia đình như mong muốn. Cũng như nhiều vùng nông thôn khác ở Việt Nam, họ vẫn thích con trai hơn con gái. So với người Kinh, phụ nữ người dân tộc thiểu số thường chịu áp lực lớn hơn đặc biệt là từ người chồng và gia đình chồng về việc có con trai.

Em thích con trai hơn. Nếu vợ em đẻ 2 con gái, em sẽ nói với cô ây đẻ thêm 1 đứa nũa để có con trai.

- Vượng, Dao, nam, 26 tuổi, đã kết hôn và vợ đang mang thai, làng A4.

Đấy là sụ ép buộc với người phụ nũ H'mong phải có con trai. Em sẽ có con thư 3 nếu hai đứa đầu của em là con gái. Nhưng nếu đứa thư ba là con gái em có thể không sinh con thư 4 . Nó phụ thuộc vào việc chồng em nói như thế nào.

- Chợ, H'mong, nũu, 24 tuổi, đã kết hôn, làng A4. 
Tôi đã dự định chỉ có hai con. Nhưng bố mẹ tôi ép tôi phải sinh con cho đến khi có con trai. Không ai trong số anh chị em gia dình chồng tôi có con trai. Tất cả chúng đều là con gái. Vì thế gia đình chồng tôi nói là tôi phải có con trai. Chồng tôi đã rất buồn và uống rượu say bởi vì cả ba đứa con đầu của tôi đều là con gái. Thật là may mắn, đến đứa thứ tư là con trai.

- Hải, Kinh, nư, 39 tuổi, cưới chông người Dao, làng A2

Sự an toàn của tuổi già được xem như là lý do chính giải thích tại sao nhất thiết phải có con trai. Theo những người dân trong làng, con trai thường được thích hơn vì đó là người nối tiếp dòng họ và chăm sóc cha mẹ lúc tuổi già, trong khi con gái thì thường về nhà chồng sau khi cưới. Tuy nhiên, nhờ có sự biến đổi nhanh chóng và vị trí kinh tế xã hội của người phụ nữ được nâng cao (qua giáo dục và lao động), thái độ phải có con trai bắt đầu thay đổi, nó được phản ánh qua ý kiến sau đây:

Nếu tôi có hai con gái, cả hai chúng nó đều học hành tốt và có nghề nghiệp tốt thì tôi không cần phải có con trai. Con gái và con rể tôi có thể chăm sóc tôi lúc tuổi già. Tuy nhiên, trong làng vẫn có nhiêu người không suy nghĩ nhu tôi.Họ vẫn muốn có con trai vì như vâyy ho cảm thấy an toàn khi về già ho có người chăm sóc.

- Võ, Kinh, nam, 42 tuổi, kinh doanh, quản lý gia đình tốt, làng B1

\subsection{Tiếp cận kế hoạch hoá gia đình và dịch vụ chăm sóc sức khoẻ sinh sản}

Phỏng vấn thế hệ cha mẹ ở tất cả các nhóm dân tộc trong một thời gian dài, họ đều biểu lộ mong muốn có quy mô gia đình nhỏ. Những người già ở trong làng nói rằng có thể tránh thai bằng cách thử nghiệm phương pháp tính kỳ kinh, hút điều hoà kinh nguyệt, trong một số trường hợp thì dùng thuốc nam. Tuy nhiên, trước năm 1990 các cặp vợ chồng trong vùng nghiên cứu có ít kiến thức cũng như các phương pháp tránh thai hiện đại còn ít. Đến giữa những năm 1990 chương trình kế hoạch hoá gia đình mới bắt đầu được tiến hành ở khu vực này. Đầu tiên ở Tràng Xá sau đó tiến hành ở Phương Giao. Hiện tại thuốc tránh thai được phát miễn phí cho những cặp vợ chồng nào muốn thực hiện kế hoạch hoá gia đình.

Theo chương trình này, mỗi làng có ít nhất một cộng tác viên dân số, đây là người sẽ đưa ra những lời khuyên về thực hiện kế hoạch hoá gia đình và phân phát các phương tiện tránh thai như thuốc tránh thai, bao cao su cho những người dân trong làng. Cộng tác viên dân số được tuyển chọn từ những người nông dân biết đọc biết viết, có một chút học vấn và đã kết hôn. Trong tất cả các làng nghiên cứu ngoại trừ làng $\mathrm{B} 4$, làng người H'mong tất cả cộng tác viên dân số đều là nữ. Trong làng $\mathrm{B} 4$, có hai người thanh niên trẻ đã kết hôn ở độ tuổi 20 được chọn làm cộng tác viên dân số vì làng này ở vùng núi cao, có những nơi trong làng đi lại rất khó khăn. Hơn nữa, cũng vì ở làng ít phụ nữ có chồng, có chút học vấn được gia đình cho phép làm nhiệm vụ này. Mỗi cộng tác viên dân số nhận một chút phụ cấp hàng tháng và do cán bộ dân số xã giám sát. 
Trước khi tiến hành chương trình kế hoạch hoá gia đình hiện tại, đặt vòng là biện pháp kế hoạch hóa gia đình duy nhất ở miền núi xa xôi này. Việc thực hiện phương pháp này rất ít kể từ khi nhân viên y tế phụ trách đặt vòng đến địa điểm này không thường xuyên. Những người phụ nữ muốn đặt vòng phải tự chịu mọi chi phí đến Thái Nguyên. Hầu như không ai thực hiện vì điều kiện đường xá và thiếu phương tiện giao thông. Một bà mẹ người Kinh độ tuổi 40 từ làng $\mathrm{A} 2$ mô tả sự khó khăn của bà như sau:

Vào nhũng năm 1980, việc đi lại tù đây đến thành phố Thái Nguyên đề đặt vòng rất khó khăn. Nếu khi đó tôi đặt vòng thì tôi đã có hai đứa con. Sau khi tôi sinh con thứ 4, tôi quyết định như vậy là đủ. Mặc dù đi lại khó khăn tôi vẫn đi đến Thái Nguyên để đặt vòng.

Trong vùng nghiên cứu, kế hoạch hoá gia đình đã phổ biến ở người Kinh. Sau đó, việc phòng tránh thai được người dân tộc thiểu số chấp nhận. Khi kế hoạch hoá gia đình vẫn còn là nhận thức mới mẻ, nhiều phụ nữ trong làng, đặc biệt là người dân tộc thiểu số bị chồng hoặc gia đình chồng cấm đặt vòng.

Năm 1994, 3 tháng sau khi tôi sinh con út, cán bộ y tế gợi ý tôi nên đi đặt vòng. Chồng tôi không cho phép tôi đặt vòng vì anh ta nghe nói rằng vòng ngăn cản người chông quan hệ tình dục với vợ. Nó mất rất nhiêu thời gian để giải thích với anh ta về lợi ích của đặt vòng và có quy mô gia đình nhỏ.

- Lưu, Dao, 44 tuổi, đã kết hôn có 4 con, nông dân, làng A5

Hiện tại kế hoạch hoá gia đình được phần lớn người dân chấp nhận. Đã từ lâu không còn có sự chống đối sử dụng phương tiện tránh thai ở những người dân tộc thiểu số. Hầu hết những người đã có gia đình cho rằng họ đã tiếp cận đầy đủ và có lợi khi thực hiện chương trình kế hoạch hoá gia đình. Trong khi đặt vòng vẫn còn là phương pháp sử dụng rộng rãi, trong những năm qua, số người đã kết hôn sử dụng thuốc tránh thai có tăng lên. Những phụ nữ có chồng hiện có thể đặt vòng ở trạm y tế xã, thuốc tránh thai và bao cao su có thể nhận từ cộng tác viên dân số hoặc mua ở cửa hàng thuốc ngoài thị trấn. Trong khi làm việc tại cộng đồng, chúng tôi nhận thấy những người có gia đình có kiến thức khá tốt về kế hoạch hoá gia đình. Tuy nhiên, một câu hỏi cần phải đặt ra là những người phụ nữ trẻ có chồng ở vùng sâu, liệu có nhận được những thông tin đầy đủ về các lựa chọn kế hoạch hoá gia đình và liệu họ có nhận được dịch vụ chăm sóc sức khoẻ sinh sản có chất lượng?

Thứ nhất, có số lượng đáng kể phụ nữ biểu lộ sự không thoải mái khi đặt vòng hoặc uống thuốc tránh thai; tuy nhiên, hầu hết trong số họ có ít kiến thức và tiếp cận với các dịch vụ kế hoạch hoá gia đình khác. Tác dụng phụ như đau lưng, nóng rát dạ dày, mệt mỏi,... đều được nói đến. Ý kiến sau khá điển hình:

Tôi không thể đặt vòng vì nó làm tôi mệt và gầy. Tôi không biết nên sủ dụng phương pháp nào khác.

- Xuân, Dao, nữ, 37 tuổi, kết hôn có 4 con, làng A5 
Tôi đặt vòng sau khi sinh con đầu lòng. Tôi cảm thấy ốm yếu vì thế tôi đến gặp y sỹ để tháo vòng. Sau đó tôi có thai. Sau khi sinh con thứ ba tôi uống thuốc. Khi uống thuốc tôi cũng cảm thấy mệt. Sau đó tôi lại đặt vòng. Tôi không có lựa chọn nào khác.

- Phương, Dao, nũu, 29 tuổi, kết hôn có 3 con, làng A4

Nhiều người phụ nũ trong làng nghĩ rằng uống thuốc có hại. Vì thế ho đặt vòng măc dù họ không thích.

- Xuân, Dao, nũu, 31 tuổi, 2 con, làng Al

Phần lớn phụ nữ nói rằng họ cố gắng chịu đựng sự không thoải mái về thể chất do các phương pháp tránh thai gây ra. Trong khi đó, vẫn còn nhiều người không sử dụng các biện pháp tránh thai. Một số phương pháp cổ điển được áp dụng như tính vòng kinh, mặc dù là người ta còn chưa hiểu rõ ràng thế nào là giai đoạn an toàn. Khi những phương pháp cổ điển này thất bại, người phụ nữ luôn tìm đến việc hút điều hoà hoặc phá thai. Hiện tại, hút điều hoà có thể tiến hành tại trạm y tế xã, trong khi đó nạo phá thai chỉ thực hiện ở trung tâm y tế huyện ở Đình $\mathrm{Cả}^{3}$. Trong quá trình làm việc tại địa phương, không phải là khó gặp những phụ nữ ở độ tuổi từ 20 đến 30 đã có ít nhất 1-2 lần hút điều hoà kinh nguyệt hay nạo phá thai. Những cuộc nói chuyện với những người phụ nữ này cho thấy họ không có hiểu biết đầy đủ về mặt trái của những biện pháp này.

Chồng tôi sủ dụng bao cao su. Nếu hết bao cao su chúng tôi sẽ phải hút điều hoà kinh nguyệt, tôi đã làm một lần ở trạm y tếxã. Không mất ít tiền nào cả.

- Chiên, Kinh, nữ, 21 tuổi, kết hôn có 1 con, làng A3

Một lần tôi nạo thai ở trạm Y tếTràng Xá. Bác sỹ làm rất tốt. Nếu tôi có thai dưới 1 tháng, bác sỹ sẽ hút điều hoà kinh nguyệt cho tôi ở đó... trước khi phá thai, tôi uống thuốc. Tôi quên không uống thuốc mấy hôm vì vậy mà tôi có thai. Bây giờ tôi đặt vòng vì thế tôi không phải lo lắng về việc quên uống thuốc.

- Thanh, Tày, nũu, 28 tuổi, kết hôn có 1 con, làng B2.

Mặc dù không có số liệu chính xác, chúng tôi có ấn tượng ở vùng nghiên cứu, người Kinh và Dao nạo phá thai nhiều hơn người H'mong. Nếu tất cả các phương tiện tránh thai thất bại, người H'mong luôn để sinh chứ không nạo thai, thậm chí ngay cả khi họ đã đạt được quy mô gia đình như mong muốn. Thái độ của người H'mong đối với việc nạo phá thai khá khác người Kinh, người Kinh luôn nghĩ rằng phá thai là biện pháp cần thiết để phòng gia đình khỏi đói nghèo. Những quan niệm này không thay đổi qua các thế hệ đối với cả người Kinh và người dân tộc.

Trước đây, phá thai được tiến hành tại phòng khám khu vực Đình Cả. Tuy nhiên hiện tại phụ nữ phá thai thích đi đến bệnh viện Đình Cả hơn. 
Em nghĩ phá thai là xấu và bất hợp pháp. Em không cho vợ em phá thai ngay cả khi có đứa con thú 10.

- Sình, H'mong, nam, 22 tuổi, có vợ và một con trai, làng B4

Tôi chưa bao giờ có ý định phá thai. Nếu đưa trẻ sinh ra tôi sẽ chăm sóc nó. Tại sao tôi lại giết chúng. Tôi không biết rõ ràng về phá thai nhưng tôi chưa bao giờ có ý định giết con tôi.

- De, H'mong, nữ, 54 tuổi, có chồng 12 con, làng B4

Nếu có thai lân thứ 3 em sẽ đi bệnh viện Đình Cả để phá thai. Cuộc sống của chúng em rất khó khăn nếu có con thứ 3. Cả gia đình sẽ phải gánh chịu...

- Thơ, Kinh, nữ, 22 tuổi, có hai con, làng A2

Em nghĩ phá thai là mắc tội giết người. Với nhũ̃ng nhà nghèo, nhất thiêt phải phá thai nếu người vợ có nhiều hơn hai con.

- Ngàn, Kinh, nũu, 21 tuổi, chưa kết hôn, làng A2

Em không biết phá thai là phạm pháp hay không phạm pháp. Nhưng gia đình em không đủ thức ăn để chăm sóc bọn trẻ, vợ nên phá thai. Cô ấy không phải lo lắng quá nhiều về khía cạnh pháp luật.

- Viễn, Kinh, nam, 20 tuổi, chưa cưới, làng Bl

Mặc dù bao cao su là phương tiện tránh thai được cộng tác viên dân số trong làng phân phát nhưng nó không phải là phổ biến. Nhận thức rất phổ biến ở cả người già và người trẻ là phụ nữ có trách nhiệm thực hiện kế hoạch hoá gia đình nhiều hơn nam giới. Nhiều ông chồng từ chối sử dụng bao cao su, mặc dù họ biết được các bà vợ không thoải mái khi sử dụng thuốc tránh thai hoặc vòng tránh thai. Điều này đặc biệt đúng đối với các dân tộc thiểu số khi họ cho rằng sử dụng bao cao su là bất tiện khiến sự thương lượng giữa các cặp vợ chồng về việc lựa chọn biện pháp tránh thai phù hợp không có kết quả.

Tôi nói với chông tôi rằng vòng làm cho tôi đau lưng và nóng rát dạ dày. Tôi nói anh ta sử dụng bao cao su thì tôi sẽ tháo vòng. Anh ta trả lời không dùng và cười.

- Phương, Dao, nũu, 29 tuổi, cưới chồng có 3 con, làng A4

Chồng tôi tù̀ chối sử dụng bao cao su. Anh ta đã thử một lần. Anh ấy thấy bất tiện khi sử dụng bao cao su. Vì thế tôi uống thuốc.

- Ty, Dao, nũu, 40 tuổi, cưới chông có 4 con, làng A4

Nhiều cặp vợ chông nghĩ sử dụng bao cao su là phức tạp và kém hiệu quả hơn nhũng phương pháp tránh thai khác. Người dân cảm thấy xấu hổ khi đi đến trạm để lấy bao cao su.

- Trương trạm, nam, trạm y tếxã Phương Giao 
Nhiều người dân nhận thức sai về việc sử dụng bao cao su. Họ có xu hướng cho rằng sử dụng bao cao su có liên quan tới vấn đề đạo đức. Một số cặp vợ chồng trẻ cho rằng việc sử dụng bao cao su là không đúng đắn giống như là có hành vi mại dâm được coi là tội phạm của xã hội.

Tôi nghĩ nếu chông và vợ chung thủy với nhau thì họ không phải sủ dụng bao cao su. Bao cao su chủ yếu cho những người thích ngủ với người khác để bảo vệ anh ta khỏi bệnh tật. Nó không thực sự phục vu cho việc tránh thai.

- Thuần, Kinh,nũu, 27 tuổi, kết hôn có 1 con, làng B3

Người mang bao cao su trong người là người xấu. Chỉ có mại dâm và không chung thuỷ mới dùng bao cao su.

- Sài, H'mong, nam, 24 tuổi, kết hôn có 2 con, làng B4

Thanh niên có gia đình thường nhận thức không đúng về các phương pháp kế hoạch hoá gia đình dựa vào vòng tránh thai, thuốc tránh thai, bao cao su, tính kỳ kinh và nạo phá thai. Một số cặp vợ chồng nói đến việc triệt sản. Tuy thế, chỉ vài người dùng đến nó như là một phương pháp để hạn chế mang thai. Trong khi cộng tác viên dân số khá tích cực trong việc cấp phát các phương tiện tránh thai chẳng hạn như bao cao su, thuốc tránh thai cho hầu hết người đã có gia đình, nhưng họ nói rằng đã thất bại đối với những cặp vợ chồng sống ở những vùng sâu trong làng. Điều này đặc biệt đúng với các cặp vợ chồng dân tộc thiểu số vì đường xá đi lại khó khăn. Ngoài ra, nhiều cộng tác viên cung cấp phương tiện kế hoạch hoá gia đình cho phần lớn những người dân dùng đến chúng nhưng lại không cung cấp đủ thông tin về lợi ích của chương trình kế hoạch hoá gia đình và hướng dẫn cách sử dụng một cách đúng đắn. Vì vậy một số lượng khá lớn các cặp vợ chồng trẻ đã thất bại khi muốn đạt mục tiêu sinh sản của họ.

Cộng tác viên dân số đã phân phát cho em miến phí nhũng bao cao su này hàng tháng. Nhưng cô ấy quá bận nên không nói với em là sủ dụng nhu thế nào. Em có thể hiểu cô ây. Cô ây bận rộn nhiều với công việc đồng áng vì tất cả các con của cô ây đang đi học... Em cũng nhận được thuốc tránh thai tù cộng tác viên dân số. Người hàng xóm của em nói rằng nếu em có thai và em không muốn sinh con, em có thể uống nhiều viên thuốc này ví dụ 3-4 viên 1 lần để phá thai. Em chưa làm điều đó.

- Sơn, Dao, nũu, 23 tuổi, kết hôn có 2 con, không đi học, làng A5 


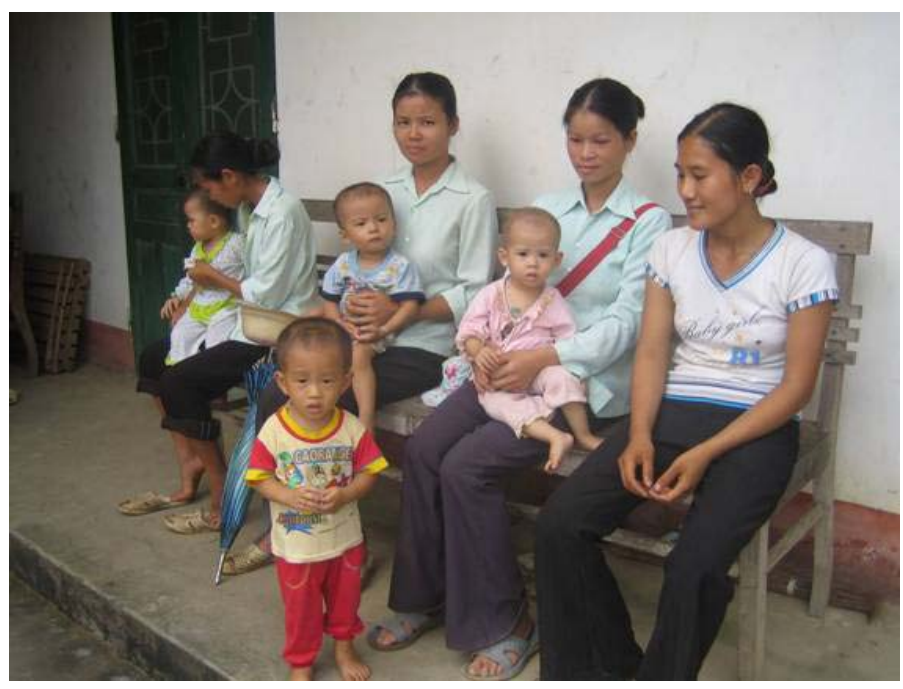

dink 21. Dhüng bà mẹ tré ở vìng sâu cía xẽ Phuiong Gias và con ciua họ. Dhä́ng bì mẹ này đã phải dạy tù̀ 3 háng đồ tến trạm y tế xẽ tiêm chüng cho con. Chínk phui Oiệt Dam cung cấp dịch oụ chăm sóe sức khớ miễn phí cho tré dưới 6 tuổi.

\subsection{Sinh con và chăm sóc trước, sau sinh}

Phần lớn thanh niên trong làng nghiên cứu, đặc biệt là những người có ít hiểu biết những gì ở bên ngoài làng của họ luôn trở thành người mẹ ở độ tuổi 20. Sự phát triển kinh tế gần đây của Võ Nhai, đặc biệt việc thành lập được trạm y tế xã vào những năm 1990 đã có tác động tốt đến sự chuẩn bị bước vào giai đoạn làm mẹ của nữ thanh niên, đặc biệt với người Kinh. Trước đây, phụ nữ có thai nhận được các dịch vụ chăm sóc trước khi sinh rất kém. Phụ nữ không có đủ dinh dưỡng và hiếm khi khám thai trong thời kỳ thai nghén. Họ luôn phải làm việc ngoài đồng cho đến ngày gần đẻ. Ý kiến sau đây khá phổ biến:

Trước đây chúng tôi hiếm khi có kiểm tra sức khoe. Nếu người phụ nũ muốn khám thai thì họ phải đi bộ ra Đình Cả. Tôi chua bao giờ khám thai đến tận khi tôi có chửa đứa con thứ 6 . Tôi không gặp nhân viên y tế cho đến tận ngày sinh con.

- Lưu, Kinh, nữ, 55 tuổi, nông dân, làng A3

Tôi chưa bao giờ nghỉ làm việc trước ngày sinh. Tôi luôn làm việc suốt cả thai gian mang thai 4 đứa con. Mặc dù tôi được phân công làm việc khác khi có thai nhưng tôi vẫn làm việc đến khi được 9 tháng. Thay vì thu hoạch, tôi được phân công phơi 14 bao thóc và giặt quần áo cho tất cả mọi người trong gia đình nhà chông tôi. Những bà mẹ trẻ ngày nay thường được nghỉ trước khi sinh 1 tháng và có lẽ 2 tháng sau khi sinh. Trước đây hiếm khi có thịt để ăn. Bây giờ phụ nũ mang thai luôn có đủ dinh dướng.

- Hải, Kinh, nũ, 40 tuổi, lấy chồng người Dao, làng A2

Đẻ tại nhà, đặc biệt với con đầu lòng không còn phổ biến ở vùng nghiên cứu. Khi phụ nữ trong làng mang thai họ thường nhận được lời khuyên từ cộng tác viên dân số 
hoặc nhân viên y tế khám thai định kỳ 3 tháng 1 lần ở trạm y tế xã. Nhân viên trạm y tế xã thường xác định ngày sinh cho thai phụ. Nếu cần có can thiệp thủ thuật họ sẽ chuyển thai phụ đến bệnh viện huyện một đến hai tuần trước ngày sinh.

Vài bệnh nhân, đặc biệt là bệnh nhân nữ, chỉ muốn khám bởi các cán bộ y tế nũ. Nếu cán bộ y tếlà nam, họ có thể không cho khám. Việc này rất phổ biến ở đây.

- Trạm trương, nam, trạm y tế xã Phương Giao

Phần lớn phụ nữ khi sinh con lần đầu đều đến trạm y tế xã. Một số phụ nữ người Kinh có điều kiện kinh tế khá giả có thể đi đến thị trấn huyện để sinh. Thảo, phụ nữ người Kinh ở làng $\mathrm{A} 2$ là một ví dụ: Thảo mới sinh con đầu lòng, cô chọn bệnh viện Đình Cả để sinh con vì nghĩ rằng chất lượng dịch vụ và cơ sở vật chất có sẵn và tốt hơn ở trạm y tế xã, gia đình cô sẵn sàng trả chi phí cho bệnh viện cao hơn so với trạm y tế, chi phí không phải là vấn đề đối với gia đình cô. Một số lượng đáng kể phụ nữ thích sinh con dạ tại nhà nhất là với phụ nữ dân tộc thiểu số. Phụ nữ người dân tộc đặc biệt là người H'mong có thể vẫn chưa tự nguyện sinh con với sự hỗ trợ của nhân viên y tế (đặc biệt là nam giới) hoặc sinh tại trạm y tế.

Tù quan sát của em, phụ nũ trong làng này thường sinh con đầu ở trạm y tế hoặc ở bệnh viện. Nhũ̃ng đưa thư hai hoặc ba họ sinh tại nhà. Lần đầu tiên họ thấy sọ vì vậy họ muốn mọi thứ chắc chắn bằng cách đến gặp nhân viên y tế. Sau lần đầu tiên, họ tự tin hơn, có kinh nghiệm hơn vì vậy họ sinh con tại nhà.

- Chợ, H'mong, nư, 20 tuổi, chưa kết hôn, làng B4

Một vài trường hợp đẻ tại nhà không có chủ ý vì thai phụ không có đủ thời gian để đến trạm y tế xã hoặc vì gia đình không có phương tiện đưa thai phụ đến cơ sở y tế. Trước đây (đặc biệt đối với các làng dân tộc thiểu số) khi các con đường chưa được xây dựng người dân mất thời gian đáng kể để đi từ nhà đến trạm y tế. Nếu người phụ nữ đợi đến tận khi có các cơn co tử cung mới đi đến trạm thì không kịp. Khi phụ nữ đẻ tại nhà, người mẹ và những người có kinh nghiệm sẽ giúp đỡ họ. Một nhân viên y tế kể lại câu chuyện điển hình sinh con tại nhà như sau:

Mẹ của thai phu thường giúp đỡ con gái họ đẻ tại nhà. Theo nhũng điều đã được nghe kể, trước khi đẻ tại nhà người dân sẽ luộc que núa và một số sợi dây chắc. Ho sủ dụng que núa để cắt rốn cho đứa trẻ. Tại trạm y tế xã, chúng tôi có túi đõ đẻ, chúng tôi sử dụng để đơ đẻ ở đây. Nhưng chúng tôi không cung cấp cho nhũng người đẻ tại nhà.

Theo nhân viên y tế và những người dân trong làng, tỷ lệ mẹ chết ở đây trong những năm qua rất thấp. Việc sinh đẻ có thể khiến người phụ nữ gặp khó khăn, nhu cầu về lao động nông nghiệp đặc biệt khi nền kinh tế phát triển nhanh chóng và thiếu động cơ máy móc khiến người mẹ và đứa trẻ phải chịu những nguy cơ đáng kể. Nhiều phụ nữ 
làm mẹ lần đầu, đặc biệt người Dao và H'mong nói rằng họ phải vội làm việc không lâu sau khi sinh. Trích dẫn sau đây khá điển hình:

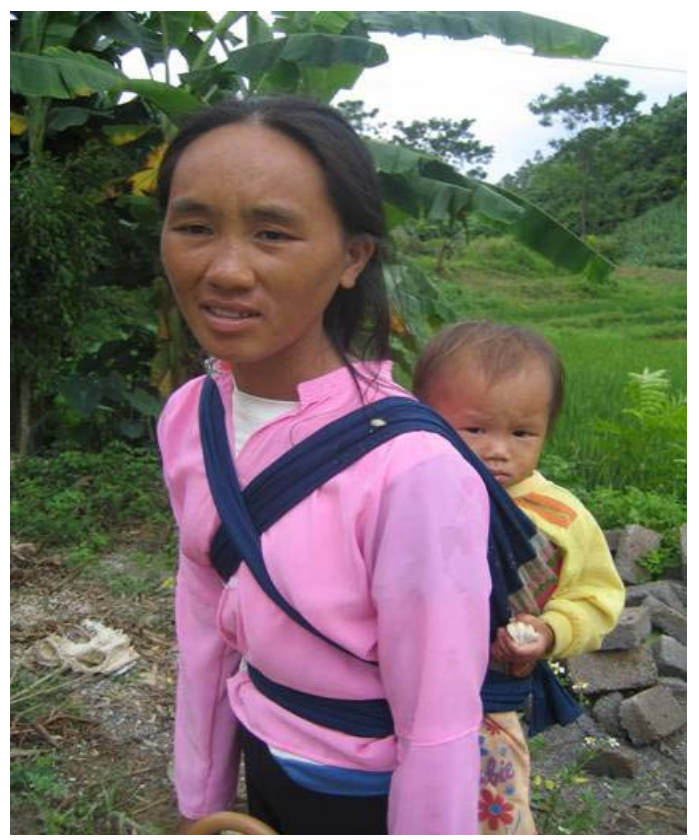

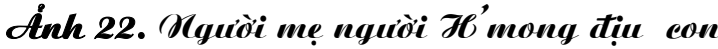
trên luing trở về nhà tù̀ ngò̀i đồi cank táe. Xhu cầu phụ nũ làm nông nghiệp vất cao vì sư phát triền kinh tế nhank chóng ò̀ thiếu máy móe sản xuất nông mghiệp. Điều này làm xuất hiện uhüng nguy cơ súc khoé cho bà mẹ và tré em. Dhiều phụ mũ, tặe biệt là nquiời Dao và $\mathcal{X}^{\prime}$ 'mong phải vội làm việe rất sớm sau khi sinh.

Em phải vác ngô trên lưng, canh tác trên cánh đồng, trông và chặt mía hàng ngày đến tận khi sinh. Sau khi sinh, em được nghi chưa đến một tháng. Sau đó em lại phải quay trở lại làm việc.

- Chợ, H'mong, nũu, 24 tuổi, kết hôn có 1 con, làng B4

Khoảng 9-10 ngày sau khi đẻ em phải đi làm. Không ai bắt em làm việc đó nhuing không có ai giúp chông em cả. Anh ấy không thể tư làm mọi việc đồng áng được. Chúng em chẳng có máy móc gì cả. Em mang con mới sinh đi làm cùng em.

- Xuân, Dao, nữ, 31 tuổi, kết hôn có 2 con, làng A2

Em phải đi thu hoạch ngô 4 ngày sau khi sinh. Mặc dù có rất nhiều người trong nhà nhưng em vấn phải làm. Em sợ bị nghèo đói. Em sợ phải ăn sắn và củ tù̀ thay cơm.

- Lưu, Dao, nũu, 44 tuổi, làng A5

Bố me chồng em bắt em đi làm. Em địu đứa con được một tháng của em ở trên lưng. Em phải đi bộ rất xa. Con gái em bi ốm thường xuyên vì ở ngoài trời năng. Khi con em ốm, em không thể đi làm. Bố me chồng em nói rằng em lười.

- Xuân, Dao, nũu, 24 tuổi, nông dân, làng A4 


\section{Chương VI KẾT LUẬN VÀ KHUYẾN NGH!}

Võ Nhai là huyện miền núi, vùng sâu nhất và kém phát triển nhất của tỉnh Thái Nguyên. Trong những thập kỷ vừa qua huyện đã nhận được các chương trình hỗ trợ của Nhà nước để góp phần xóa đói giảm nghèo. Người dân nơi đây đã chứng kiến những thay đổi và phát triển của xã hội có sự tác động của các chương trình can thiệp này.

Bằng phương pháp nghiên cứu định tính kết hợp với định lượng từ nguồn số liệu phong phú như đánh giá nhanh, điều tra dân số, điều tra hộ gia đình, phỏng vấn sâu nhóm nghiên cứu đã tiến hành ở 2 xã Tràng Xá và Phương Giao là nơi có 3 nhóm dân tộc chính là người Kinh, H'mong, Dao; đại diện cho các xã nghèo, nông thôn và miền núi ở phía Bắc Việt Nam, chúng tôi đã tìm hiểu sự thay đổi kinh tế xã hội nhanh chóng trong cuộc sống của thanh niên vùng sâu và những tác động khác nhau đến người Kinh và dân tộc thiểu số. Đầu tiên, nghiên cứu tìm hiểu mức độ thay đổi và các yếu tố ảnh hưởng đến sự thay đổi của thanh niên về tham gia học tập, quá trình chuyển tiếp từ học hành đến việc làm và quá trình đi đến kết hôn, trở thành cha mẹ của thanh niên từ 15 đến 29 tuổi. Nghiên cứu này cũng chứng minh những kết quả của sự thay đổi về phúc lợi xã hội và đời sống của thanh niên, đặc biệt với những vấn đề liên quan đến tình dục và sức khoẻ sinh sản của người Kinh và dân tộc thiểu số. Dựa trên những kết quả thu được từ nghiên cứu chúng tôi đề xuất những giải pháp nhằm góp phần tăng cường phát triển về con người ở vùng nghiên cứu. Sau 4 tháng thu thập số liệu, nhóm nghiên cứu đã tiến hành phỏng vấn sâu gần 190 đối tượng và tiến hành điều tra theo mẫu ở 150 hộ gia đình, qua phân tích chúng tôi đưa ra những kết luận và kiến nghị chính như sau:

Huyện Võ Nhai, đối tượng của chương trình giảm nghèo từ sau những năm 1990 đã nhận được những lợi ích từ chương trình này. Đường liên thôn, liên xã đã được xây dựng, trường học cũng đã được nâng cấp và xây mới, người dân được hưởng dịch vụ chăm sóc sức khỏe thông qua việc xây dựng trạm y tế và cung cấp các dịch vụ miễn phí, chương trình thẻ tín dụng và phát triển nông nghiệp cũng là những lợi ích mà người dân được hưởng trong thời gian qua. Tuy nhiên người Kinh có nhận thức và được hưởng lợi nhiều hơn người dân tộc thiểu số từ những chương trình này.

Thanh niên từ 15 đến 29 tuổi ở vùng nghiên cứu chưa được chuẩn bị tốt về giáo dục so với thanh niên ở nhiều nơi khác của Việt $\mathrm{Nam}$, trình độ học vấn còn thấp, nhất là người dân tộc và đặc biệt dân tộc H'mong có học vấn thấp nhất do rào cản về ngôn ngữ. 
Tỷ lệ học sinh học cấp trung học cơ sở và trung học phổ thông trong vùng nghiên cứu rất thấp do khoảng cách từ nhà đến trường khá xa; sợ mất đi lao động trẻ em là rào cản chính đối với những gia đình nghèo muốn cho con tiếp tục đến trường; chương trình và nội dung của chương trình do Bộ Giáo dục và Đào tạo quy định chưa phù hợp với học sinh và giáo viên vùng nghiên cứu. Nhờ sự hỗ trợ của chương trình 135 học sinh vùng này được miễn giảm học phí, học sinh dân tộc được hỗ trợ sách giáo khoa nhưng chỉ có số ít người trong độ tuổi từ 15 đến 29 được hưởng lợi từ chương trình này do chương trình không phân bổ đến tất cả các nhóm dân tộc có mức thu nhập khác nhau. Hơn nữa, chương trình này chủ yếu nhằm tăng cường tỷ lệ học sinh đến trường mà chưa chú ý đến cải thiện chất lượng học tập, theo phân tích của chúng tôi đây là nguyên nhân gốc rễ của việc bỏ học sớm. Như vậy, để nâng cao chất lượng giáo dục cũng như khuyến khích người học phải tạo ra những cơ hội học tập tốt cho học sinh ngay từ những năm đầu mới đến trường, cần lưu ý nhất đến đối tượng là những thanh niên đã bỏ học sớm đặc biệt là nhóm dưới 20 tuổi. Ngôn ngữ sử dụng trong các lớp học cũng là vấn đề giáo viên cần quan tâm để đảm bảo học sinh có thể giao tiếp tốt. Chương trình đào tạo bổ sung cho thanh niên và người trưởng thành rất hữu ích ở vùng nghiên cứu bởi chương trình này không gặp trở ngại về khoảng cách từ nhà đến trường cũng như không làm mất đi cơ hội làm việc (thay vì mất thời gian đi học ban ngày) của học sinh. Cần lưu ý chương trình này cần có mục đích phù hợp với nhu cầu của người học như để tổng hợp lại kiến thức hay để xóa mù chữ cho người trưởng thành. Hơn nữa, chương trình đào tạo cũng phải thiết kế sao cho giáo viên và học sinh có thể lựa chọn chương trình và nội dung cho phù hợp.

Kinh tế trong vùng nghiên cứu đã phát triển trong thời gian qua. Nghề chính của người dân nơi đây là nông nghiệp như trồng lúa để tiêu thụ, ngô và mía tạo ra thu nhập. Tuy sự phát triển kinh tế có chiều hướng lạc quan song người nông dân vẫn phải đối mặt với những thách thức của thị trường nông nghiệp như sự phụ thuộc rất nhiều vào giống và phân bón, thiếu nước, thiếu thông tin về cung cầu, giá cả thị trường, hạn chế về vốn và kỹ thuật. Nghề phi nông nghiệp rất hạn chế ở vùng nghiên cứu, chỉ một số ít người dân có thể làm nghề buôn bán hoặc làm cán bộ chính quyền ở xã hay huyện, không có nhà máy nào ở khu vực nghiên cứu. Sự thay đổi nguồn thu và cơ hội nghề nghiệp đang chuyển biến chẳng hạn như nhiều người có thể đi làm ở các nhà máy, khu công nghiệp ở Thái Nguyên hay những nơi khác. Người Kinh có nguồn thu nhập phong phú hơn người dân tộc. Như vậy, chương trình đào tạo bổ sung nên đa dạng bao gồm kỹ năng của học sinh phổ thông và chương trình đào tạo nghề để giúp người học có thể trở thành công nhân chuyên nghiệp. Ngoài ra chương trình này cũng nên chú ý đến kỹ năng quản lý kết hợp với các kỹ năng khác và giáo dục chung. Với những thanh niên không đi học mà tìm việc làm ngoài ngành nông nghiệp, được cung cấp những kỹ năng hướng nghiệp sẽ giúp họ tìm việc làm và trở nên có khả năng sản xuất khi có thể đào tạo ngay trong thị trường lao động. Nên tổ chức các hình thức đào 
tạo bao gồm dịch vụ việc làm và tư vấn để tăng cường hiệu quả đào tạo nghề cho thanh niên vùng nghiên cứu này.

Xét tổng thể điều kiện sống của người dân vùng nghiên cứu đã được cải thiện đáng kể trong những năm gần đây nhưng nghèo vẫn còn tồn tại. Một số không thực sự nghèo nhưng họ có nguy cơ nghèo khi ốm đau, thất bại khi thoát ly quê hương đi lao động ở bên ngoài... do trong cộng đồng không có mạng lưới an toàn. Người Kinh và H'mong ở Tràng Xá có điều kiện kinh tế tốt hơn người Kinh và Dao ở Phương Giao do họ dễ dàng tiếp cận với chợ và thị trấn nên khả năng bán được sản phẩm ra thị trường tốt hơn. Chương trình đào tạo nghề cần đáp ứng yêu cầu của nhiều nhóm thanh niên khác nhau nhưng mục đích chính là cung cấp những năng lực do công việc đòi hỏi và lồng ghép những kỹ năng sống. Trong bối cảnh của vùng nghiên cứu, cần tăng cường những kỹ năng sống để giúp thanh niên giải quyết và biết dung hoà những tình huống thách thức để thích hợp với sự thay đổi nhanh chóng của xã hội mà họ đang trải qua. Điều này đặc biệt quan trọng đối với những thanh niên muốn tìm cơ hội làm việc ở bên ngoài. Những kỹ năng sống là những kỹ năng thiết yếu giúp họ thành công trong lao động. Hơn nữa đào tạo những kỹ năng sống cũng quan trọng để thanh niên biết cách từ bỏ rượu, thuốc lá, nghiện ma tuý và các tệ nạn xã hội.

Từ năm 2000 địa bàn nghiên cứu đã có dự án phát triển cơ sở hạ tầng bao gồm đường giao thông và điện. Hầu hết các làng trong xã đều đã có đường và điện. Tỷ lệ hộ gia đình có xe máy đã tăng lên trong những năm qua. Kết hợp giữa việc cải thiện đường và có xe máy giúp cho người dân có điều kiện dễ dàng hơn trong việc tiếp cận với dịch vụ chăm sóc sức khoẻ và các phúc lợi công cộng khác. Tuy có nhiều cố gắng để cải thiện nước sạch và vệ sinh môi trường nhưng kết quả vẫn có những hạn chế. Nhìn chung, cơ sở vật chất ở làng người Kinh tốt hơn làng người Dao và H'mong. Sự khác nhau giữa các dân tộc được giải thích do người Dao và H'mong có xu hướng sống ở vùng cao hơn và xa hơn người Kinh. Ngoài ra có thể do sự thiếu hụt về nguồn vốn và vai trò chính trị của con người thấp làm cho họ chưa thể tham gia vào các quyết định phân bổ nguồn lực cho sự phát triển cơ sở hạ tầng. Như vậy, cần có chương trình can thiệp nhằm duy trì sự phát triển cơ sở hạ tầng ở vùng nghiên cứu, chính quyền địa phương nên phát triển các kế hoạch và biện pháp để cho phép tiến hành các chương trình giáo dục nghề nghiệp; các bên liên quan bao gồm các tổ chức Nhà nước, phi chính phủ, các nhà tài trợ nên cùng tham gia để đảm bảo tính bền vững và hiệu quả của các chương trình nhằm đáp ứng những nhu cầu của thanh niên. Trong bối cảnh nghiên cứu, lãnh đạo địa phương cũng như cha mẹ nên tham gia vào những công việc này vì họ là những người có nhiều ảnh hưởng đến sự quá trình thanh niên trở thành những người làm kinh tế. Cũng như chính quyền cần xem xét và chú trọng hơn đến vai trò của người dân tộc thiểu số trong việc đưa ra quyết định phân bổ và sử dụng nguồn lực ở địa phương nhằm giúp họ được hưởng lợi trực tiếp từ những phúc lợi xã hội như người Kinh. 
Mặc dù hiện tại không có đại dịch HIV/AIDS nhưng quan hệ tình dục và sức khỏe sinh sản của thanh niên là vấn đề cần được quan tâm. Thanh niên có học vấn thấp và người dân tộc thiểu số có nguy cơ về tình dục và sức khỏe sinh sản nhiều hơn những người có học vấn cao và dân tộc Kinh. Tuy có trình độ học vấn thấp nhưng người H'mong không có quan hệ tình dục trước hôn nhân nhiều hơn những nhóm khác. Mặc dù quan hệ tình dục trước hôn nhân chưa được xã hội chấp nhận nhưng tỷ lệ này vẫn tăng lên trong những năm gần đây. Hiểu biết và sự tiếp cận với dịch vụ chăm sóc sức khỏe sinh sản của thanh niên vẫn còn có những hạn chế, hầu hết không có kiến thức đầy đủ về dậy thì, tình dục an toàn, các phương pháp kế hoạch hoá gia đình, HIV/AIDS và các bệnh lây truyền qua đường tình dục. Một số thanh niên học được những kiến thức về vấn đề này qua bài giảng ở chương trình trung học cơ sở, qua chị gái, bạn bè hay tivi, cha mẹ rất ngần ngại khi nói với con cái về chủ đề này. Thanh niên chưa kết hôn không thể tiếp cận với các biện pháp tránh thai do cộng tác viên dân số cung cấp. Như vậy những thanh niên chưa có gia đình cần được tăng cường hiểu biết về tình dục và sức khoẻ sinh sản. Những chủ đề này nên bao gồm sinh lý về sức khoẻ sinh sản, dậy thì, tình dục an toàn, HIV/AIDS, bệnh lây truyền qua đường tình dục, các phương pháp kế hoạch hoá gia đình. Chương trình này sẽ thành công hơn nếu kết hợp với việc đào tạo những kỹ năng sống để tăng cường các giải pháp giải quyết những hành vi nguy cơ. Ví dụ, các chương trình nên thiết kế dạy thanh niên những kỹ năng cần thiết để vượt qua những nguy cơ áp lực xã hội như uống rượu, tình dục không an toàn, nghiện ma tuý hoặc quan hệ với gái mại dâm. Chương trình này cũng nên giúp con người phát triển lòng tự trọng, tự tin và giúp họ vượt qua sang chấn một cách có hiệu quả. Chương trình nên được tiến hành sớm (trước tuổi dậy thì) và sử dụng cách tiếp cận dựa vào cộng đồng và trường học. Nên tập trung vào những thanh niên không đi học, những thanh niên dân tộc thiểu số và những người sống ở vùng sâu, vùng xa. Chương trình học cơ bản trở nên nhạy cảm trước những truyền thống văn hoá và ngôn ngữ khác nhau. Cha mẹ nên cùng tham gia vào chiến dịch này với tư cách như là những nòng cốt của chương trình giáo dục về sức khoẻ sinh sản sức khoẻ tình dục. Bằng chứng tỷ lệ phụ nữ có thai và quan hệ tình dục trước hôn nhân cho thấy thanh niên cần tiếp cận với dịch vụ tư vấn sức khoẻ sinh sản, dịch vụ này nên đảm bảo sự tế nhị và tư vấn cặn kẽ với những đối tượng liên quan ở địa phương bao gồm thanh niên, những người trưởng thành, thế hệ cha mẹ và lãnh đạo cộng đồng.

Khác với thanh niên chưa kết hôn, những thanh niên đã kết hôn dễ dàng tiếp cận với dịch vụ kế hoạch hoá gia đình và sức khoẻ sinh sản nhưng họ vẫn phải đối mặt với những thách thức liên quan đến tình dục, sức khoẻ sinh sản và quyền kết hôn. Tại địa điểm nghiên cứu, kết hôn tuổi thanh thiếu niên vẫn còn tồn tại ở người H'mong và Dao đặc biệt là những người nghèo và có học vấn thấp. Một hành vi quan trọng khác làm ảnh hưởng đến sức khoẻ sinh sản đang có xu hướng tăng lên là tổ chức đám cưới tốn kém, chi phí đám cưới tăng lên dẫn đến việc sau khi cưới cặp vợ chồng trẻ thường phải 
lao động vất vả để trả nợ cho đám cưới, chính những người mẹ trẻ phải lao động sớm sau khi sinh con. Một vài trường hợp, vì hộ gia đình không có người làm hoặc không có người chăm sóc, những người mẹ này phải mang con đi làm đồng. Mặc dù tỷ lệ mẹ chết không cao ở vùng nghiên cứu nhưng chúng tôi thấy nhu cầu lao động nông nghiệp sẽ làm xuất hiện những nguy cơ về sức khoẻ cho bà mẹ và trẻ em. Hoạt động can thiệp để đảm bảo chất lượng sức khỏe tình dục và sức khỏe sinh sản cho thanh niên khu vực nghiên cứu nên tập trung vào những nhu cầu khác nhau của nhóm thanh niên đã xây dựng gia đình. Thanh niên trong vùng nghiên cứu nên được tạo điều kiện để đến với mục tiêu sinh sản, để nhận dịch vụ chăm sóc sức khoẻ sinh sản và để được làm mẹ an toàn. Nhận thức về làm mẹ an toàn nên tăng cường hơn nữa bao gồm đẻ an toàn nhờ sự giúp đỡ của nhân viên y tế đã được đào tạo, có sự chăm sóc toàn diện cho mẹ và bé trước và sau khi sinh. Hơn nữa, người dân cần được thảo luận về cách tổ chức đám cưới và lựa chọn những nội dung liên quan đến sự phong phú của đám cưới và giảm chi phí để góp phần giúp người dân thoát khỏi nghèo đói và đảm bảo sức khỏe.

Tỷ lệ sinh đã giảm có ý nghĩa ở vùng nghiên cứu trong thập kỷ vừa qua. Mong muốn quy mô gia đình nhỏ là rất phổ biến. Việc sử dụng các biện pháp tránh thai được chấp nhận, các dụng cụ kế hoạch hoá gia đình sẫn có cho những người có gia đình. Tuy thế, một số cặp vợ chồng vẫn không đạt được quy mô gia đình như mong muốn. Thanh niên ở đây không nhận được thông tin đầy đủ về cách lựa chọn phương pháp kế hoạch hoá gia đình, mong muốn có con trai là lý do mấu chốt giải thích tại sao phụ nữ không kiểm soát việc sinh con (so với người Kinh những phụ nữ dân tộc thiểu số có ít quyền tự chủ hơn và thường cảm thấy áp lực lớn hơn từ chồng và gia đình chồng về việc có con trai). Ngoài ra trong việc lựa chọn các biện pháp tránh thai, khi người phụ nữ cảm thấy không thoải mái dùng phương pháp uống thuốc hoặc đặt vòng họ có thể cam chịu nhưng họ cũng có thể không tiếp tục sử dụng các biện pháp tránh thai nữa cũng là nguyên nhân dẫn đến việc không đạt được quy mô gia đình như ý muốn. Con trai được thích hơn con gái đặc biệt với người H'mong và người Dao, việc này làm quyền tự chủ của phụ nữ cũng như việc kiểm soát sinh sản kém hơn. Khi có thai ngoài ý muốn, việc nạo phá thai vẫn xảy ra với những phụ nữ đã có chồng trong nhóm nghiên cứu, đặc biệt là người Kinh và người Dao. Hầu như phụ nữ tuổi dưới 35 ít nhất đã có một hoặc hai lần nạo thai. Sự lạm dụng này có thể ảnh hưởng đến sức khỏe phụ nữ nếu quá trình thực hiện không đảm bảo kỹ thuật. Quan niệm phổ biến là kiểm soát sinh sản là trách nhiệm của phụ nữ chứ không phải là của nam giới. Nam giới thiếu trách nhiệm trong việc kiểm soát sinh sản tạo ra gánh nặng cho phụ nữ. Bên cạnh đó, có những thái độ không đúng về bao cao su, khuynh hướng xem việc sử dụng bao cao su có nghĩa là liên quan đến không chung thủy và gái mại dâm làm tăng thêm gánh nặng với phụ nữ. Như vậy cộng đồng cần tạo điều kiện, nâng cao vai trò của người phụ nữ như tạo cơ hội cho 
họ tham gia chính quyền, tham gia các cuộc họp, làm kinh tế,... điều này sẽ góp phần tăng cường vị thế của họ trong việc kiểm soát sinh con theo ý muốn.

Chương trình kế hoạch hoá gia đình hiện tại cũng có nhiều điểm cần cải thiện. Đầu tiên, người phụ nữ cần có nhiều thông tin và có nhiều lựa chọn cho chương trình kế hoạch hoá gia đình hơn. Phương pháp đặt vòng tránh thai, thuốc uống và sử dụng bao cao su nên có đầy đủ, miễn phí hoặc giá rẻ. Hơn nữa, cần khuyến khích nam giới tham gia vào chương trình kế hoạch hoá gia đình và kiểm soát hành vi tình dục và sức khoẻ sinh sản. Có thể cử một cộng tác viên dân số là nam và và một là nữ cùng làm ở một xã. Những người này cùng làm công việc kế hoạch hoá gia đình nhưng họ nên tiếp xúc với những người cùng giới tính. Những tình nguyện viên nên chú ý đến những cặp vợ chồng ở vùng sâu, vùng xa. Nên có phụ cấp cao hơn cho cộng tác viên dân số. Có sự đánh giá, giám sát để đảm bảo chất lượng của chương trình kế hoạch hoá gia đình tại xóm, bản. Mặt khác, khi tiến hành hút điều hoà kinh nguyệt hay nạo phá thai cần đảm bảo chất lượng tốt và giảm thiểu tác hại với sức khoẻ. Dịch vụ kế hoạch hoá gia đình được cải thiện bao gồm tư vấn, nhiều giải pháp kế hoạch hoá gia đình sẽ giải quyết việc có thai ngoài ý muốn. 


\section{TÀl LIỆU THAM KHẢO}

1. 1998b. Decision no. 135/1998/QD-TTg of July 31, 1998 to approve the program on socio-economic development in mountainous, deep-lying, and remote communes with special difficulties. Hanoi, Vietnam.

2. 2006. "Explaining ethnic minority poverty in Vietnam: a summary of recent trends and current challenges." Hanoi, Vietnam: the World Bank.

3. 2006. World Development Report 2007: Development and the Next Generation. Washington, DC; the World Bank.

4. Asian Development Bank. 2002. Vietnam: Indigenous Peoples, Ethnic Minorities, and Poverty Reduction. Environment and Social Safeguard Division, Regional and Sustainable Development Department. Manila, the Philippines: Asian Development Bank.

5. Baulch, Bob, Truong Thi Kim Chuyen, Dominique Haughton and Jonathan Haughton. 2004. "Ethnic minority development in Vietnam: A socio-economic perspective." In Economic Growth, Poverty, and Household Welfare in Vietnam, edited by Paul Glewwe, Nisha Agrawal, and David Dollar, Pp. 273-310. Washington, DC: The World Bank.

6. Committee for Ethnic Minorities and UNICEF. 2003. Reaching Out for Change: A Qualitative Assessment of Government Healthcare and Education Policies Affecting the Women and Children of Ethnic Minorities. Hanoi, Vietnam: UNICEF.

7. Gallup, John Luke. 2004. "The Wage Labor Market and Inequality in Vietnam." In Economic Growth, Poverty, and Household Welfare in Vietnam, edited by Paul Glewwe, Nisha Agrawal, and David Dollar, Pp. 53-94. Washington, DC: The World Bank.

8. Government of Vietnam. 1998a. Decision No. 133/1998/QD-TTg of July 23, 1998 to ratify the National Target Program on Hunger Elimination and Poverty Alleviation in the 1998-2000 period. Hanoi, Vietnam.

9. Hardy, Andrew. 2002. Red hills: migrants and the state in the highlands of Vietnam. Hawaii: University of Hawaii Press.

10. Ministry of Health and General Statistics Office. 2003. Results of Vietnam National Health Survey 2001-2. Ha Noi, Vietnam: Medical Publishing House. 
11. Ministry of Health, General Statistics Office, UNICEF, and WHO. 2005. Report on Survey Assessment of Vietnamese Youth. Hanoi, Vietnam.

12. Ministry of Labor, War Invalids and Social Affairs and UNDP. 2004. Taking stock, planning ahead: evaluation of the national targeted programme on hunger eradication and poverty reduction and program 135. Hanoi, Vietnam.

13. Ministry of Planning and Investment. 2006. Five-Year Socioeconomic and Development Plan. Hanoi, Vietnam.

14. National Committee for Population, Family, and Children and ORC Macro. 2003. Vietnam Demographic and Health Survey 2002. Calverton, Maryland, USA: Committee for Population, Family and Children and ORC Macro.

15. National Research Council. 2005. Growing Up Global: The Changing Transitions to Adulthood in Developing Countries. Washington, DC: National Academy Press.

16. Swinkels, Rob and Carrie Turk. 2004. "Poverty and Remote Areas: Evidence from New Data and Questions for the Future." Hanoi, Vietnam: the World Bank.

17. UNAIDS, UNICEF, and Development Research and Consultancy Center. 2000. Sexual Perception and Behavior of Vietnam's Ethnic Minority Group: Hmong, Dao, Thai, and Khmer Group in Lao Cai, Lai Chau, and Kien Giang Province. Hanoi, Vietnam.

18. van de Walle, Dominique and Dileni Gunewardena. 2001. "Sources of ethnic inequality in Viet Nam” Journal of Development Economics 65:177-207.

19. Vietnam General Statistics Office. 2001. Census monograph on marriage, fertility and mortality in Vietnam: Levels, trends and differentials. Hanoi, Vietnam: Statistical Publishing House.

20. Vietnam General Statistics Office. 2001. Census monograph on marriage, fertility and mortality in Vietnam: Levels, trends and differentials. Hanoi, Vietnam: Statistical Publishing House.

21. World Bank. 2004. Vietnam Development Report 2004: Poverty. Report No. 27130-VN. Washington, DC: Poverty Reduction and Economic Management Unit, East Asia Pacific Region.

22. World Health Organization. 2003.Health and ethnic minorities in Vietnam. Hanoi, Vietnam. 


\section{Hội đồng dân số}

Hội đồng dân số

Số 41, Lê Hồng Phong

Quận Ba Đình

Hà Nội, Việt Nam

Điện thoại: + 844734 5821/2/3/4/5/6

Fax: +84-4-734-2827

Email:pchanoi@popcouncil.org website: www.popcouncil.org
Trường Đại học Y khoa Thái Nguyên

Số 284, đường Lương Ngọc Quyến

Thành phố Thái Nguyên, Việt Nam
Điện thoại: +840280 852671

Fax: +840280 855710

Email:dhyktn@hn.vnn.vn

www.tnmc.edu.vn 


\section{(2) Population Council}

HÔl ĐỒNG DÂN SỐ

Số 41, Lê Hồng Phong

Quân Ba Đinh

Hà Nội, Việt Nam

Điện thoại: +84 4734 5821/2/3/4/5/6 Fax: +84 47345827

E-mail: pchanoi@popcouncil.org www.popcouncil.org
TRƯỜNG ĐẠI HOC Y KHOA THÁl NGUYÊN

Số 284, đường Lương Ngọc Quyền

Thành phố Thái Nguyên, Việt Nam

Điên thoại: +84 0280852671

Fax: +840280855710

E-mail: dhyktn@hn.vnn.vn

www.tnmc.edu.vn 